\title{
BIOGENESIS OF THE NEOPROTEROZOIC KREMYDILITE MANGANESE ORES FROM URUCUM (BRAZIL) - A NEW MANGANESE ORE TYPE.
}

Running title: Biogenesis of a Neoproterozoic manganese ore

${ }^{1}$ Federal University of Paraná State, Polytechnic Center, Geology Department, 81531-980 Curitiba, Brazil, e-mail: biondiufpr@gmail.com

${ }^{2}$ Institute for Geological and Geochemical Research, RCAES, Hungarian 14 Academy of Sciences, 1112 Budapest, Budä̈rsi u. 45, Hungary, e-mail: rodokrozit@gmail.com, gyildi@gmail.com,iv.kovacs@gmail.com,fekete.jozsef@csfk.mta.hu

$16{ }^{3}$ Eszterházy Károly University, Dept. of Natural Geography and Geoinformatics, 3300 Eger, 17 Leányka u. 6, Hungary

$18{ }^{4}$ Szeged University, Dept. of Mineralogy, Geochemistry and Petrology, 6722 Szeged, Egyetem u. 19 2-6, Hungary, e-mail: efkrisz@gmail.com

205 University of Colorado, Department of Geological Sciences, 2200 Colorado Avenue, UCB 399,

21 Boulder, Colorado 80309-0399, United States of America, e-mail: mojzsis@colorado.edu

*corresponding authors:

25 rodokrozit@gmail.com

$26{ }^{+}$The first two authors contributed equally to this work 


\section{Significance statement}

The Neoproterozoic Urucum manganese deposit (Brazil) is a $\sim 600 \mathrm{Mt}$ microbially-mediated sedimentary $\mathrm{Mn}$ ore. Proto-ore formation via sedimentation and diagenesis occurred under suboxic-oxic and semi-neutral $\mathrm{pH}$ conditions in the Ediacaran ocean, wherein microbial Mn(II) oxidation ensued from the fine-grained accumulation of Mn oxides and organic matter. Oxic conditions that facilitated enzymatic Mn oxidation and overwhelmed microbial Fe oxidation appears as a sharp contact between manganese and iron beds. The Urucum deposit arose from a complex suite of diagenetic processes, including decomposition and mineralization of microbiallyderived organic matter involving extracellular polymeric substances. Kremydilite - a new type of diagenetic concentric Mn mineral structure - formed by randomly activated heterotrophic cell colonies that generated pores in the microbialite sediment after burial, coincident with lithification.

\section{Highlights}

1. Urucum Mn deposit formed in an Ediacaran marginal basin with more than $600 \mathrm{Mt}$ of ore formed from manganiferous microbialite.

2. Kremydilite is diagenetic structure that comprises a new type of Mn ore.

3. Microbial mediation occurred during Mn ore sedimentation and diagenesis.

4. Cellular and extracellular polymeric substances from Fe and Mn bacteria and cyanobacteria were mineralized. 


\section{Abstract}

The Urucum district in Mato Grosso do Sul (Brazil), hosts the youngest and largest sedimentary Mn ore of Neoproterozoic age; units Mn-1, Mn-2, and Mn-3 are found in jaspilites and ironstones, and represent approximately $600 \mathrm{Mt}$ of extractable rock with $27-44 \% \mathrm{Mn}$ and $12-30 \%$ Fe. Highresolution optical- and cathodoluminescence microscopy, as well as Raman and FTIR spectroscopy show that the lower Mn-1 is ferruginous, while the upper Mn-1 consists mainly of $30-75$ vol. $\%$ braunite, $<0.5 \%$ aegirine, $3-15 \%$ quartz, $5-10 \%$ feldspar, and $1-5 \%$ clay minerals, including apatite, chlorite, and organic matter. Here, we model the control of this ore mineralogy by homogeneous oxidation and microbial processes. Layers Mn-2 and Mn-3 contain kremydilite, as a characteristic ore structure, with $77-95$ vol.\% cryptomelane, 0-23\% hollandite, $9-19 \%$ braunite, $7-21 \%$ hematite, and $0-5 \%$ pores filled with clay minerals and organic matter. These are present within a micro-nodule matrix composed of cryptomelane and hematite in varying proportions. The first syngenetic products of microbial enzymatic oxidation were, on the Fe side, ferrihydrite and lepidocrocite, and on the Mn side, vernadite, todorokite, birnessite, and manganite. These formed under obligatory oxic (Mn) and suboxic (Fe) conditions and close to neutral $\mathrm{pH}$. We describe the genesis of Urucum via complex diagenetic processes, which include the decomposition and mineralization of cellular- and extracellular-polymeric substances from Fe and Mn bacteria and cyanobacteria. The kremydilite forms in successive stages of oxidation of organic matter mediated by microbes, which generate pores and produce methane and $\mathrm{CO}_{2} / \mathrm{H}_{2}$ bubbles. They are a unique type of diagenetic structure formed by heterotrophic cell colonies randomly activated in the microbialite milieu following burial in suboxic neutral/alkaline conditions, sideby-side with the lithification and stabilization of the mineral assemblages. (294 words) 


\section{Keywords:}

77 (1) Urucum Ediacaran manganese deposit; (2) kremydilite; (3) microbialite; (4) enzymatic 78 oxidation, cell and extracellular polymeric substance mineralization. 


\section{INTRODUCTION}

The Urucum mining district occupies an area of approximately $800 \mathrm{~km}^{2}$ and is located in the Pantanal swamps region of west-central Brazil. Three layers of massive manganese oxides, named Mn-1, Mn-2, and Mn-3, occur interbedded with massive jasper, banded iron formations (BIFs), and massive iron formations (IF) that comprise the Santa Cruz Formation of the Neoproterozoic Jacadigo Group (Urban et al. 1992; Frei et al. 2017; Fig. 1 and SI 1-Fig). It was estimated that the Urucum district originally contained more than $600 \mathrm{Mt}$ of rock with the manganese content between 27-44 wt.\% and iron content between 12-30 wt.\% (Urban et al. 1992).

Fig. 1 HERE

The stratigraphic sequence of the Urucum region was first defined by Dorr (1945) and Almeida (1946), who also conducted the first systematic studies on the origin of iron and manganese deposits in the region. Urban et al. (1992) mapped the entire mining region, and since that time, the regional geological map has been minimally updated. Following the work of Urban et al. (1992), the most relevant changes to our understanding of the regional geology arose from the work of Freitas et al. (2011), who detailed the Jacadigo Group lithologies and defined their sedimentation environments. Biondi and Lopez (2017) identified faults that acted as conduits for hydrothermal fluids which altered the rocks of the Jacadigo Group basement, and exhaled fluids with iron and other elements at the base of the sedimentary sequence of the Urucum basin. They also correlated the Mn-1, Mn-2, and Mn-3 layers with those recognized at different Urucum sites. Various and mutually-exclusive proposed genetic models for the Jacadigo Group iron and manganese rocks have been a topic of discussion and debate since their discovery. These models can be summarized as follows: (a) marine genesis with sediments of continental origin (Dorr 1945); (b) marine genesis with sediments of marine origin (Almeida 1946; Putzer, 1958; Haralyi and Walde, 1986); (c) volcanogenic marine genesis (Walde 1981; Walde et al. 1981; Leonardos and Walde 1982; O'Connor and Walde 1985); (d) formation in a glacio-marine sedimentary 
106

107

108

109

110

111

112

113

114

115

116

117

environment followed by supergene enrichment (Schneider 1984; Schreck 1984; Leeuwen and Graf 1987; Graf et al. 1994; Costa et al. 2005); (e) sedimentary genesis in a flooded graben with a contribution of hydrothermal leaching from hidden mafic rocks (Haralyi and Walde 1986; Walde 1988; Trompette et al. 1998); (f) SEDEX, or sedimentary exhalation (Dardenne 1998); and (g) sedimentary genesis in an oceanic environment with a deep-sea hydrothermal contribution (Klein and Ladeira 2004). Recently, Angerer et al. (2016) proposed a biologically-mediated origin in a glacio-marine environment for the carbonate BIFs of the Santa Cruz Mine region located on the southeastern part of the Santa Cruz plateau. In a recent comprehensive study, Biondi and Lopez (2017) (a) recognized the biogenic mediation during the genesis of manganese ore; (b) described in detail mineral structures termed by them kremydilites and argued that they may represent fossilized microbial colonies from organisms that mediated the formation of the manganese layers; and (c) modified the region's stratigraphy based on the fossil assemblages, showing that the Urucum iron-manganese rocks correlate to the carbonate rocks of the Bocaina Formation, of the Corumbá Group, previously considered post-depositional to those of the Jacadigo Group.

The Ediacaran Period of formation is proposed by the authors based on the presence of the Corumbella Verneri fossil, found amidst the ironstones separating Mn-2 from Mn-3 (Figs 2B and Figs 4B to D, Biondi and Lopez 2017). This fossil has always been considered Ediacaran, which establishes a wider interest concerning the Urucum Mn deposit.

Here, we explore the origin of kremydilites described in Biondi and Lopez (2017) and present a model that explains the processes of sedimentation and diagenesis that facilitated the origin of these structures and the manganese layers. Recent works have provided a geological setting diagram, mineralogy (low magnification optical microscopy, X-ray diffraction, SEM-EDSbased), and chemistry datasets based on bulk samples and in situ (SEM-EDS) data (e.g. Frei et al. 2017), but microbial mediation as a plausible mechanism for the genesis of these rocks is still under debate (Biondi and Lopez 2017). We expand the results of these previous studies with more detailed optical microscopy (OM), cathodoluminescence microscopy (CL), Raman- and Fouriertransform infrared spectroscopy (FTIR) to document the micro-mineralogy, presence, and distribution of embedded organic matter. The goal here is to explore the role of microorganisms 
134 in the process of manganese ore genesis from Urucum, and to understand the diagenesis, structures, 135 and process of formation of kremydilites.

\section{GEOLOGICAL AND GEOCHRONOLOGICAL BACKGROUND}

The Santa Cruz Formation is mainly composed of jaspilitic BIFs, (massive) iron formations (IFs), massive banded jasper, and ferruginous arkosic silt and sandstones. The greatest thickness of the Santa Cruz Formation, 396 m, is documented in drill hole (DH) 44-28, made at the Vetorial Mine, and bookended by a $40 \mathrm{~m}$ section at the northern end of the Rabicho plateau (Fig. 2). The massive manganese layers, Mn-1, Mn-2, and Mn-3, occur in the lower half of this formation and are interlayered with BIFs and massive jasper.

The Jacadigo and Corumbá Groups are considered coeval (Biondi and Lopez 2017) and of Ediacaran age, based on the presence of stromatolites below Mn-1 (Jacadigo Group) and Corumbella fossils in the rocks of the Bocaina and Santa Cruz Formations (respectively, Corumbá and Jacadigo Groups). The age of this fossil in the ironstones of the Santa Cruz Formations (Jacadigo Group) and limestones of the Tamengo Formation (Corumbá Group) was estimated at ca. 550 Ma (Germs 1972; Grant 1990; Grotzinger et al. 1990; Hofmann and Mountjoy 2001; Bengtson 2002). The proposed age of this horizon was 555-542 Ma by ichnofossils, identified by

151 Parry et al. (2017), in the Bocaina Formation. These ages are consistent with U-Pb geochronology

152 of detrital zircons from a volcanic ash layer intercalated with carbonate rocks of the Tamengo 153 Formation, at $543 \pm 3 \mathrm{Ma}$ (Babinski et al. 2008), and the ${ }^{40} \mathrm{Ar} /{ }^{39} \mathrm{Ar}$ age of $587 \pm 7 \mathrm{Ma}$ for 154 cryptomelane in the Mn-1 to Mn-3 layers (Piacentini et al. 2013; Frei et al. 2017 and references 155 therein).

156 Dating braunite from the Mn-1 layer, Piacentini et al. (2013) interpreted the $547 \pm 3$ to $513 \pm 4$ $157 \mathrm{Ma}\left({ }^{40} \mathrm{Ar} /{ }^{39} \mathrm{Ar}\right)$ age as a minimum age, arguing that the $\mathrm{Ar} / \mathrm{Ar}$ thermo-chronological system was 158 rejuvenated by tectonic warming, which was considered a consequence of the metamorphism 159 underwent by the Jacadigo Group rocks. Also using the ${ }^{40} \mathrm{Ar} /{ }^{39} \mathrm{Ar}$ method, they dated $513 \pm 3 \mathrm{Ma}$ 160 some crystals of muscovite collected from the arkoses that are interlayered with the BIFs, which 161 was also considered metamorphic. According to Piacentini et al. (2013), these ages are "possibly 
related to disruption between the Amazon Craton and the Apa River cratonic fragment and they do not reflect the time of Jacadigo Group deposition", which would be greater than $590 \mathrm{Ma}$, and concluded that Jacadigo's rocks would have at least $587 \pm 7$ Ma.

To reconstruct the paleogeography of the sedimentary basin, Mn-2 and Mn-3 were leveled and used as stratigraphic markers. This procedure makes it possible to outline the geometrical differences between the Mn-layers. This reconstruction shows that stratigraphy observed within the Urucum plateaux always includes $\mathrm{Mn}-1$, and that this stratum lines the basin floor wherever the Jacadigo Group is described (e.g., Urban et al. 1992; Biondi and Lopez 2017) (Fig. 2). Yet, unlike Mn-1, both the Mn-2 and Mn-3 layers occur only in the interpreted depocenter of the basin, in the region of Urucum, Santa Cruz and southeast of the Morro Grande plateaux (Fig. 1). In the interior of each plateau, mining of the manganese layers reveals that Mn-2 and Mn-3 are flat and parallel to one another, whereas the Mn-1 unit follows the contours of the basin floor. By positioning Mn-2 and Mn-3 in their respective stratigraphic horizons it is now possible to reconstruct Urucum marginal basin floor (Fig. 2).

The origin of the sediments of Urucum has been detailed elsewhere (Walde 1981; Walde et al. 1981; Leonardos and Walde 1982; O'Connor and Walde 1985, Haralyi and Walde 1986; Walde 1988; Trompette et al. 1998, Dardenne 1998, Klein and Ladeira 2004, Angerer et al. 2016; Biondi and Lopez 2017), and we provided a brief synopsis, here. The Santa Cruz Formation formed as an in-fill of an ancient graben with iron and manganese-rich sediments overlying fluvial deposits from the Urucum Formation, while limestones from the Bocaina and Tamengo Formations were deposited in the shallow marginal regions (Biondi and Lopez 2017; Fig. 2). As has been proposed for some Phanerozoic Mn ores (e.g. Polgári et al. 2012ab, 2016b), the most probable sources of the $\mathrm{Mn}$ and Fe was hydrothermal exhalations in a submarine environment. The Mn and Fe fluids were transported to the sedimentary basin via basement faults (SI 1-2-Figs) that became activated 
each time the graben widened. During inundations attributed to sedimentation of the Mn-1, Mn-2, and Mn-3 units, Mn and Fe discharged on basin floor mixed with Mn and Fe brought in by water from the open ocean as well as with that originating from the exhalates located outside the Urucum basin.

\section{Fig. 2.}

A transition between the Urucum and Santa Cruz formations through the Mn-1 horizon exists in all mines from the area (Urban et al. 1992). Furthermore, Biondi and Lopez (2017) showed that there are typically two or more layers of Mn-1 manganese ore with meter- to decimeter-scale thicknesses, locally interlayered with jaspillite-rich clasts. We now describe these relationships in more detail.

The lower Mn-1 ore layer is relatively siliceous and composed mainly of braunite, cryptomelane cement and $\mathrm{Mn}-\mathrm{Fe}$-rich carbonate, whereas the Upper Mn-1 layer is a fine-grained, massive, clastic layer of manganese oxides with undulating parallel lamination and numerous decimeter-scale oblate structures, characterized by a massive core and silty clay and arkose wrap dubbed amygdalites (Fig. 3C). The ore layer is bounded by sharp planar contacts typically overlain by conglomerate consisting of angular granite pebbles in an arkosic matrix. Layers Mn-2 and Mn-3 contain mostly massive manganese ore with lamination. They are composed mainly of cryptocrystalline manganese oxides and hydroxides, commonly containing kremydilites (Figs. 3DE and 4) with minor amygdalites (Biondi and Lopez 2017). In Mn-2 and Mn-3, what have been interpreted as the remains of microbial colonies form oblate, $5-15-\mathrm{cm}$ sized concentric kremydilite structures, within the fine-grained and biomass-rich basin floor shale as well as intergranular, oblate gas structures (Figs. 4A, C, F, and H). The main features of the ore beds, including their mineralogical and selective element compositions are summarized in Table 1.

\section{Fig. 3}


Fig. 4.

Table 1.

The textures of the Mn-2 and Mn-3 layers express as 1-10 millimeter-sized spherical, often zoned manganese oxide micro-nodules that coalesce to form the massive ores. These probably

214 involved the aforementioned kremydilite structures made solely of manganese and minor iron oxides. All observed Mn-2 and Mn-3 outcrops have kremydilites, although they do not constitute all of the ore mass from these layers. As previously described, kremydilites occur between the ore bands (Figs. 4A-J), which are massive or banded (and/or laminated), and are distributed in the layers in an apparently homogeneous manner. It is difficult to estimate the volume occupied by kremydilites owing to the fact that they are complicated to see in discontinuous outcrops. For those observed on the mining fronts, it is likely that they occupy more than about $50 \%$ of the ore layer 221 by volume.

\subsection{Forms and type of kremydilites}

Kremydilites occur only between the laminations of the massive ore in the Mn-2 and Mn3 layers, and are absent in banded- or massive ironstones. They are always contoured by the fine laminated ore with micronodular, microbialite micro-texture, in which the diameters of micronodules range from 0.2-0.8 mm (Fig. 4; SI 5-Fig, zones 1, 2, 3; and zones 20 to 24). Microbialite and micro-nodule rich layers are in turn contoured by wavy microbialite layers apparently composed by the amalgamation of nodules smaller than $10 \mu \mathrm{m}$. Its forms are oblate, centimeterto-decimeter scale (Fig. 3) and concentrically zoned. Structures of what we interpret to be the

230 different growth development stages also appear to occur together (Figs. 4 and 5), and each stage

231 of growth is marked by the presence of pores, which delineate coarse concentric, sometimes 232 incomplete envelopes (Fig. 4). Kremydilites on the other hand are porous structures absent of 233 micro-nodules. They occur in varied forms as shown in Figures 4A to H. 
Fig. 5.

The simplest kremydilite form consists of a bubble-filled nucleus (Fig. 4A), followed by those with a nucleus having diffuse borders (Figs. 4C). Other forms include a nucleus with one

237 (Fig. 4E) or two (Fig.4G) diffuse concentric laminae (or shells). The more complex kremdylites, 238 with a nucleus and many concentric shells delineated by millimeter to submillimeter pores, 239 crosscut with lighter, massive, and metallic zones (Figs. 4I). In general, the various kremydilite 240 forms contain many oblate structures (Figs. 4A, E, and G). These are less than $20 \mathrm{~mm}$ across 241 distributed along the layer containing the kremydilite, and inside and/or near them. Mesoscopic 242 inspections of sawn samples (Fig. 4K) as well as thin and polished sections, show that each layer 243 contains disseminated pores. The quantity of pores increases toward the margin of the shell, and 244 each lamina is surrounded and delimited by areas with high pore density (Biondi and Lopez 2017). The pores are often lined by shiny acicular microcrystals of cryptomelane and/or contain organic matter (Biondi and Lopez 2017). Although kremydilites do not contain micro-nodules, and are instead inside the micronodular bands and contoured by microbialite layers, the outermost zones of kremydilite appear to have a composition similar to that of amalgamated micro-nodules. In these zones, the presence of ring-like structures of carbonate microcrystals are common (SI 5Fig, zone 16 - detail image, Biondi and Lopez, 2017). The zones closer to the nucleus (zones 9, 10, and 11) contain mixed anhedral minerals with metallic luster, but with larger dimensions than the anterior zones. The nucleus of the kremydilites (zones 12 and 13) are microgranular and 253 heterogeneous.

\section{SAMPLES}

Representative samples and the methods applied (number of photos and spectra) are summarized in Table 2 and Fig. 3-4. Localities of the sample collection are shown in Fig. 2. 
The samples of Mn-1 are (Fig. 3, SI 3-Fig): COR-4B, a clast-bearing massive ironstone; 259 COR-6, a massive manganese ore; COR-7, a very fine-grained clast-bearing ore with braunite and carbonate; COR-10, a sandy, detritic ore with braunite, quartz, and feldspar; COR-31, an arkosic sandstone with hematite matrix; and COR-32, an amygdalite with cryptomelane massive nucleus surrounded by arkosic sandstone with hematite matrix.

Samples of Mn-2 and Mn-3 are: COR-81, a sample of massive manganese ore; COR-78also with diffuse boundaries; COR-78-D1 (Fig. 4C), a kremydilite with a diffuse core enveloped by two shells, also with diffuse boundaries; COR-75-B5 (Fig. 4E), a porous kremydilite nucleus; COR-75-2 and COR-48 (Fig. 4J), complex kremydilites with porous core surrounded by many concentric, porous shells; and COR-36-A1 (Fig. 4G), a kremydilite with a nucleus and at least two shells (hereafter the samples are cited without COR).

\section{Table 2.}

\section{METHODS}

Thin section and polished section mineralogy was described and quantified using a ZEISS Axio Imager A2m microscope (Federal University of Paraná State, Polytechnic Center, Geology Department, Curitiba, Brazil).

Petrographic structural-textural studies by optical rock microscopy (OM) were also made on 12 thin sections in transmitted and reflected light (NIKON ECLIPSE 600 rock microscope, Institute for Geology and Geochemistry, Research Centre for Astronomy and Earth Sciences, Hungarian Academy of Sciences - IGGR RCAES HAS, Budapest, Hungary).

Cathodoluminescence (CL) petrography was carried out on 7 thin sections using a 281 Reliotron cold cathode cathodoluminescence apparatus mounted on a BX-43 Olympus 
polarization microscope (Szeged University, Hungary). The accelerating voltage was $7-7.7 \mathrm{keV}$

283 during the analysis. Cathodoluminescence spectra were recorded by using an Ocean Optics 284 USB2000+VIS-NIR spectrometer. Spectrometer specifications are a wavelength range of 350$2851000 \mathrm{~nm}$ and 1.5-nm (FWHM) optical resolution.

286 Mineralogical analyses were performed on three bulk samples using a Rigaku Miniflex-600 287 X-ray diffractometer (XRD), with carbon monochromator and $\mathrm{Cu}-\mathrm{K} \alpha$ radiation, at $40 \mathrm{kV}$ and 15 288 mA (IGGR RCAES HAS, Budapest, Hungary). Mineral composition was determined on randomly 289 oriented powdered samples. The diffraction patterns were processed using Siroquant V4 software, 290 and the modal contents determined by the Rietveld method.

In situ FTIR microspectrometry used for micro-mineralogy and organic material 292 identification on nine thin sections to determine the mineralogy and characterize the organic 293 material, as well as clarify the concentric structures (415 spectra, IGGR RCAES HAS, Budapest, 294 Hungary), using a Bruker FTIR VERTEX 70 equipped with a Bruker HYPERION 2000 295 microscope with a 20x ATR objective and MCT-A detector. During attenuated total reflectance 296 Fourier transform infrared spectroscopy (ATR) analysis, the samples were contacted with a Ge 297 crystal $(0.5-\mu \mathrm{m})$ tip with $1 \mathrm{~N}$ pressure. The measurement was conducted for $32 \mathrm{~s}$ in the $600-4000$ $298 \mathrm{~cm}^{-1}$ range with $4-\mathrm{cm}^{-1}$ resolution. Opus 5.5 software was used to evaluate the data. The equipment 299 inappropriate for most of Mn-oxide determinations because those peaks fall in the $<600 \mathrm{~cm}^{-1}$ range 300 (not equipped with that detector). Contamination by epoxy glue and glass was corrected for. High-resolution in situ micro-Raman spectroscopy was used for micro-mineralogy and CM 302 identification and distribution on 9 thin sections (1 polished section) (Szeged University, 303 Hungary). A Thermo Scientific DXR Raman Microscope was used, with a 532-nm (green) diode 304 pumped solid-state (DPSS) Nd-YAG laser, using 1.5-mW laser power and 50x objective lens in 305 confocal mode (confocal aperture $25 \mu \mathrm{m}$ slit). The acquisition time was $1 \mathrm{~min}$, and the spectral 
resolution was $\sim 2 \mathrm{~cm}^{-1}$ for each measurement. The distance between each point was $10 \mu \mathrm{m}$, and

307 the measurement time was 10 min. A composite image of thin sections of Raman microscopy measurements and a series of Raman spectra acquired along the vertical sections are provided in the thin section photomicrographs (arrow points to measurement direction). Diagrams are organized in terms of peak height versus analytical spot number for each of the phases along the 311 Raman-scanned section. Intensities were normalized to the highest peak for each spectrum. Raman measurements were taken on 9 samples (4B, 7, 10, 31, 36-A, 75-2, 75-B5, 48-D1,

313 81). In the case of the homogeneous-like cases $400-500$ and in the case of $75-2,800$ spectra were 314 taken along the line shown on section photos (4B, 7, 10, 31). These are systematic investigations 315 along the line profile. Spectra were obtained every $10 \mu \mathrm{m}$, providing a high-resolution sensitive 316 study. In samples 75-B5, 78-D1, and 81, the measurements were taken across whole thin sections.

317 The spectra were elaborated in two ways:

318 (1) Diagrams were organized in terms of peak height versus analytical spot number of each of the 319 phases along the Raman scanned section (main minerals and organic matter in general). (2) A 320 detailed determination of all spectra were also made. These results are summarized in tables (Excel 321 files, numbers 1, 2, and 3 indicate the intensity-1-weak, 2-moderate, 3-strong-reference data on 322 detection), in which the mineral composition can be followed from point to point, as well as the 323 type of organic matter. (Supporting Information)

324 Aside from the profile analyses, descriptions of the mineral phase transitions were also 325 constructed for clarification of aegirine (5 photos, 4 mineral spectra, and 1 profile), braunite (3 326 photos, 10 point analyses, and 1 profile across mineral transitional zones), cryptomelane (18 327 photos, 54 point analyses, and 2 profiles across spheres), and the composition of the oblate 328 structures (28 photos, 93 point analyses, and 1 profile). 
The following Raman bands were used for normalization: rhodochrosite: $\sim 1086 \mathrm{~cm}^{-1}$, dolomite: $\sim 1093-96 \mathrm{~cm}^{-1}$, apatite: $\sim 965 \mathrm{~cm}^{-1}$, quartz: $\sim 463 \mathrm{~cm}^{-1}$; todorokite $633 \mathrm{~cm}^{-1}$; manjiorite

$331641 \mathrm{~cm}^{-1}$; ramsdellite: $650 \mathrm{~cm}^{-1}$; cryptomelane: $183 \mathrm{~cm}^{-1}$ and $580 \mathrm{~cm}^{-1}$; hollandite: $585 \mathrm{~cm}^{-1}$; 332 birnessite: $656 \mathrm{~cm}^{-1}$; ferrihydrite: 707 and $1045 \mathrm{~cm}^{-1}$; goethite: 297 and $385 \mathrm{~cm}^{-1}$; celadonite: 545 $333 \mathrm{~cm}^{-1}$; barite: 446 and $985 \mathrm{~cm}^{-1}$; johannite: $785 \mathrm{~cm}^{-1}$; aegirine: $970 \mathrm{~cm}^{-1}$; jacobsite: $620 \mathrm{~cm}^{-1}$; 334 hausmannite: $661 \mathrm{~cm}^{-1}$; braunite: $210,510,685 \mathrm{~cm}^{-1}$; and carbonaceous matter: $\sim 1605 \mathrm{~cm}^{-1}$. The identification of minerals was made with the RRUFF Database (Database of Raman spectroscopy, X-ray diffraction, and chemistry of minerals: http://rruff.info/). Contamination by epoxy glue was taken into consideration. Along with the profile analyses, a detailed determination of all peaks was also made.

Comparing the two in situ methods, the AT-FTIR, which did not considerably modify the mineral phases while using the lowest exciting energy, was used to investigate the upper 1-2 $\mu \mathrm{m}$

341 of the samples. This is the also best method to determine organic matter (Polgári and Gyollai, 342 2019; Polgári et al., 2019). On the contrary, Raman spectroscopy, using higher excitation energy, 343 often caused the transformation of metastable minerals to more stable phases. This method yielded 344 information from the upper 3-4- $\mu \mathrm{m}$ depth of the sample surfaces and was the best method for 345 identifying Mn oxides and hydroxides. The Raman comparative spectra database is more extensive 346 than the AT-FTIR database.

\section{RESULTS}

\subsection{Optical (OM) and cathodoluminescence (CL) rock microscopy}

\subsubsection{Optical rock microscopy}

Thin sections represent mineralized biomats based on structural observations, which are eminently visible on smaller magnification photos (40x) (Fig. 6, SI 6-, 7-Figs). In all thin sections, 
adequately high-resolution optical rock microscopy (1000x) supports a series of mineralized biomat microstructures, mineralized microbially produced textures (MMPT) as main constituents (Fig. 6, SI 8-Fig). This microbial microtexture is a basic feature of all the samples, in transmitted as well as reflective light. Well-preserved and mineralized remains of diverse filaments with pearl necklace-like, vermiform inner signatures, and coccoid-like forms embedded in the Mn ore beds are seen, and the whole samples appear densely woven. The minerals are very fine-grained (0.5-1 $\mu \mathrm{m})$ except Mn-1, where clastic contribution occurs. The diameter of the mineralized filaments is around $0.5-1 \mu \mathrm{m}$, with variable length (Fig. 6).

Fig. 6.

Samples 4B, 7, 10, 31, 32 (all from Mn-1) include debris-like components of variable size (20-200 $\mu \mathrm{m})$. In sample 4B, it seems that the darker gray mineral grains transform to lighter phase (SI 8-Fig). The debris grains are mainly quartz with few fragments of jasper and hydrothermally altered feldspar.

\subsubsection{Cathodoluminescence microscopy}

Cathodoluminescence revealed that a part of the debris-like grains (clastic components) is probably composed of real clasts showing the bright, characteristic CL of the mineral (e.g., quartzblue, feldspar-yellowish) (Fig. 7AB, SI 9-Fig). Some other grains with sizes of some tens of $\mu \mathrm{m}$ resemble clasts but do not show luminescence. These non-luminescent grains are most probably secondary minerals formed via diagenesis (Marshall 1998; Hassouta et al. 1999).

Bright blue luminescence is characteristic of kaolinite group-dickite (supported by Raman spectroscopy; Götze et al. 2002), which occurred frequently in our samples (samples 4B, 7, 10, 31, Fig. 7A, B, G, H). The numerous small or larger bright yellow minerals are apatite grains, which often have a lighter margin. These apatites occur along the ore lenses, minerals, and laminae in a woven-like fine-grained biomat-type matrix which mark the borders as accompanying a series of 
minerals that occurred frequently (Fig. 7, SI 9-Fig) (samples 4B, 7, 10). The fine-grained rhodochrosite (mixed carbonate) show dull reddish (orange) luminescence (Fig. 7A, B) (samples 4B, 7, 10). Samples 75-2, 75-B5, and 78-D1 are non-luminescent.

\section{Fig. 7.}

\subsection{FTIR spectroscopy}

Measurements were performed in two ways: (i) randomly, in seven sections $(6,7,10,31$, 32, 36-A1, 78-F3) and (ii) along profiles, in kremydilite sample 48B (Fig. 4K) and in oblate structure (36-A2) (Fig. 4H).

\subsubsection{Local area analyses}

Mineral phases and types of organic matter for (i) are summarized in Table 3 and SI 10-

Table, according to the measuring area and frequency.

\section{Table 3.}

In summary, Fe-oxide-hydroxides (ferrihydrite, lepidocrocite, hematite) are common in all the Mn ore beds, Fe-silicates (aegirine) are common in the Mn-1 ore bed, and Fe-sulphide (pyrite) rarely occurs. Variable Mn oxides and hydroxides (todorokite, ramsdellite, pyrolusite, cryptomelane), and oxide-silicates (braunite, serandite) are the main Mn ore minerals. Besides Fe and $\mathrm{Mn}$ ore minerals, feldspar, chlorite, celadonite, kaolinite group-dickite, apatite, and quartz are moderate or minor mineral components. Variable types of organic matter occur in all samples.

\subsubsection{Analyses of kremydilite}

Three profile analyses in kremydilite sample 48B were made (Fig. 4K and Fig. 8). Two

397 profiles crossed the concentric shells of the kremydilite structure on opposite sides (A and C), and 398 one profile crossed the inner part (B).

All concentric shells and the parts intersected between these shells are heterogenous and

400 very fine-grained. Considering that minerals represent the remnants of primary $\mathrm{Mn}$ and $\mathrm{Fe}$ 
minerals, each measuring point in the concentric shells and intersected parts resulted in a mixture of minerals, with often poorly crystallized phases.

Fig. 8.

All shells and the inner part are heterogeneous and very fine-grained. Each measuring point resulted in a mixture of minerals, with often poorly crystallized phases like ferrihydrite. The shells -observed visually_often have the same mineralogy (cryptomelane, hollandite, hematite, rhodocrosite, and pores). The mineralogy of the two sides of the structure are asymmetric (Fig. 8D). Profile A (Fig. 8B), from the margin toward the inner part, contain rhodochrosite-goethite, manjiorite-todorokite, minor ferrihydrite-cryptomelane (6 shells), and in the vicinity of the inner part, cryptomelane-ferrihydrite. Profile $C$, from the margin toward the inner part, contain brauniterhodochrosite, braunite-goethite-rhodochrosite ( 3 shells), braunite-cryptomelane-rhodochrosite, braunite-rhodochrosite, braunite, cryptomelane-ferrihydrite-rhodochrosite $(2$ shells $)$, cryptomelane-ferrihydrite ( 2 shells), and cryptomelane-braunite, and in the vicinity of the inner part, cryptomelane-ferrihydrite. Profile $B$, representing the inner part from the shells to the center, contain cryptomelane-ferrihydrite, ramsdellite-rhodochrosite, birnessite-rhodochrosite (2 zones), cryptomelane-quartz-rhodochrosite, cryptomelane-birnessite-dolomite, cryptomelane-quartzrhodochrosite, ferrihydrite-cryptomelane-dolomite-quartz, and cryptomelane-quartz-dolomite. Varying amounts of pores, with or without organic matter, are characteristic in all layers and in the central parts (Fig. 4).

In summary, mineralogical assemblages contain concentric zones (or "shells") of poorly crystallized, preserved Mn (birnessite, todorokite) and Fe minerals (ferrihydrite), and mainly more stable cryptomelane, hollandite, braunite, hematite, goethite, and rhodochrosite. Profile $C$ mineral components are more stable. More stable minerals represent greater degree of crystallinity.

\subsubsection{Analyses of oblate (bubble-like) structures}


Based on OM of sample 36-A1, the outer and inner matrix and also the dark spots of the oblate structures appear very similar, with only the reflective color differing slightly (SI 11-Fig). FTIR analyses resulted in a similar mineralogy and variable organic matter composition, as the sample is very fine-grained and heterogeneous (Fig. 9). The peaks of most of the minerals show broad bands and low intensities, which are characteristic of disordered, poorly crystallized quartz, 430 carbonates, and feldspar.

\section{Fig. 9.}

Out of the oblate structures, the ore contains a matrix, micro-nodules, and dark spots. The micro-nodules and the matrix consist of cryptomelane, ferrihydrite, minor goethite, rhodochrosite, and variable organic matter. The analyzed dark spot in the outer part consists of pores, cryptomelane, ferrihydrite, minor goethite, rhodochrosite, and organic matter.

There are no micro-nodules inside the oblate structure. The light part of the matrix inside the oblate structure contains cryptomelane, ferrihydrite, quartz, minor dolomite, and organic matter. The dark part comprises dolomite, ferrihydrite, cryptomelane, and organic matter. Inside, the dark spot consists of ramsdellite, quartz, minor dolomite, and organic matter (SI 11-Table). the fine-grained rim built up of ferrihydrite, minor goethite, and organic matter; and (2) the coarsegrained phase, which is a mixture of cryptomelane, disordered quartz, rhodochrosite, dolomite, traces of braunite, and variable organic matter. Comparing the outer and inner parts, differences in 444 mineralogy are reflected in the type of carbonate (rhodochrosite outside and dolomite inside), the Mn oxides of the dark spots (cryptomelane outside and ramsdellite $\left(\gamma-\mathrm{MnO}_{2}\right)$ inside), and the occurrence of quartz in the inner part and rim, and feldspar in the outer part. On the outside of the 447 oblate structure, the rock contains pores and the typical (micronodule-bearing) microtexture of 
Mn-2 and 3, whereas inside, the micro-noduliferous textures do not exist, and pores are partially

449 filled by hollandite.

450

451

452

\subsection{Raman spectroscopy}

Nearly 11,000 spectra were taken for micro-mineralogical and organic matter composition determinations as well as for the distribution of minerals according to the thin section profiles. Representative analyzed profiles are shown in Fig. 10 and SI 12-Fig. The mineral distribution was evaluated visually based on a series of Raman profiles at the $10-\mu \mathrm{m}$ scale (Fig. 10, SI 12-Fig). The determined minerals, including FTIR data, are summarized in Table 4. Variable Mn oxides and hydroxides, Mn oxides-silicates, Mn carbonates, variable Fe oxides hydroxides, Fe silicates, Fe sulfide, ore minerals, apatite, feldspar (albite and orthoclase), mica (muscovite, chlorite, celadonite), kaolinite-dickite, barite, carbonates (strontianite, dolomite, ankerite), and quartz occur in the $\mathrm{Mn}$ ore beds. Variable organic material is also an important constituent. Based on low intensity and broad peaks, the minerals are poorly crystallized and cryptocrystalline. The representative samples contain a mixture of poorly crystallized mineral phases and organic matter.

\section{Table 4.}

\subsubsection{Mineral distribution in profiles by Raman spectroscopy}

A distribution of minerals is evident in all samples, alternating micro-laminae (a few tens of $\mu \mathrm{m}$ thick) along with the kremydilite inner part (Fig. 10, SI 12-Fig). This alternating microlamination refer to mineralized microbial cycles in the sediment pile. The documented distribution of minerals in the Mn ore beds is the following:

\section{Mn-1 from Figueirinha Mine}

- Sample 4B - Hematite (rarely aegirine)/rarely quartz alternation, starting with Mn (braunite) alternation and random apatite, and K-feldspar. 
- Sample 7 - Aegirine/braunite cycles with randomly occurring apatite, mica, and K-feldspar.

- Sample 10 - Aegirine-hematite/quartz alternation (Fe cycles) and Mn cycles superposed (braunite, serandite, hausmannite) occur with randomly occurring apatite, barite, feldspar (albite, K-feldspar), and strontianite.

Mn-1 from São Domingos Mine

- Sample 31 - Hematite (rarely kaolinite/dickite)/quartz alternation (Fe cycles), and Mn cycles superposed (braunite, manjiorite, jacobsite, todorokite, romanèchite).

- Sample 75-2 - Only Mn minerals occur, but jacobsite and hollandite contain Fe. Jacobsite alternate with cryptomelane, ramsdellite, and hollandite. Ramsdellite is the most oxic phase. In the zone of kremydilite, the micro-lamination turns into random mineral distribution. Accessory minerals are: romanèchite (psilomelane), manganite, todorokite, pyrite, and pyrolusite.

- Sample 75-B5 - Goethite is frequent only in this sample. Representative Mn cycles are composed of cryptomelane, hollandite, and occasionally, braunite. Micro-lamination is disordered, and in those zones, random mineral distribution occurs, but locally microlamination is well visible. Accessory minerals are: jacobsite, manganite, ramsdellite, todorokite, hausmannite, romanèchite, pyrolusite, ferrihydrite, apatite, and mica. occur together. Hematite and braunite also occur together, but braunite occurs separately, too. Braunite binds to hematite. Locally, pyrolusite, birnessite, romanèchite, jacobsite, 
manganite, ramsdellite, hausmannite, serandite, ferrihydrite, goethite, mica, and apatite occur.

Mn-3 from MCR Mine

- Sample 81 - Hematite alternates with Mn oxide (cryptomelane-hollandite). Accessory minerals are: todorokite, ramsdellite, jacobsite, rancieite, pyrolusite, birnessite, braunite, ferrihydrite, magnetite, and mica.

Fig. 10 .

\subsubsection{Mineral phase transitions by Raman spectroscopy}

Microscale mineral phase transitions offer very important information on syngenetic and diagenetic formation processes. Mineral compositions of Urucum samples also provide information on this aspect, which explains the focus on specific mineral transitions.

\subsubsection{Aegirine}

Aegirine is common in Mn-1, occurring as an alternating mineral with braunite. A detailed study on the phase transition was made for sample 4B (Fig. 11). The microtexture of aegirine resembles a vermiform network that intrudes into the quartz. The quartz occurs in the undulating hematite network as a gel-like segregated silica. Aegirine is present at the contact of quartz, and riebeckite seems to consume aegirine. This relationship shows that aegirine and riebeckite consume quartz. At the contact of segregated quartz, hollandite/vernadite and apatite occur. Braunite binds to hematite in the vicinity of quartz.

\section{Fig. 11.}

\subsubsection{Braunite}

Braunite also consumes segregated quartz similarly to aegirine, in a vermiform habit, and is in close contact with the hematite network (Fig. 12) (sample 4B). Segregated quartz also contains K-feldspar. Hematite occur as small clusters and contains an undulating network as mineralized biomats. 
Fig. 12.

\subsubsection{Cryptomelane}

All the spectra taken in the micro-nodules (cell colonies) and matrix material show dominant vernadite/hollandite-type Mn-oxides-hydroxide composition and a greater or less amount of cryptomelane and variable organic matter (sample 75-2). The minerals are in a cryptocrystalline mixture with variable amounts. The textural differences do not correspond to significant mineralogical differences (Fig. 13, SI 13-Fig). The central part of the micro-nodules consists of hollandite/vernadite and organic matter, around which cryptomelane, pyrolusite and ramsdellite occur.

Fig. 13. to compare the mineral composition and distribution inside the oblate structure, in its vicinity, and in the rim (sample 36-A1, Fig. 14, SI 14-Fig).

The dark spots in the outer matrix are mainly pores, except dark porous inner rims with variable thicknesses, which are composed of a hollandite-type Mn oxide phase (dominant phase), cryptomelane, and goethite. The matrix among the dark spots is built up by hollandite, cryptomelane, and goethite.

The non-porous rim of the oblate structure mainly consists of hollandite and cryptomelane in variable amounts. Rarely fine-grained clusters of goethite occur among the hollanditecryptomelane flakes.

In comparing the mineral phases and distribution in the outer, inner, and rim areas of the

542 measured oblate structure, we find that they are similar. The matrix of the inner part of the oblate 543 structure is composed of very fine-grained goethite (ferrihydrite) and small particles of Mn oxides 
544 (hollandite and cryptomelane in variable amounts); however, hollandite is dominant in the dark 545 spots. The mineral composition of the matrix and dark spots show a unified distribution, as any 546 difference or significant trend in the matrix or in the dark spots was not detected.

\section{Fig. 14.}

\subsubsection{Organic matter}

The organic matter of Mn-1 ores from Figueirinha (samples 4B, 7, and 10) and São Domingos (sample 31) area are dominated by two bands near 1320 and $1610 \mathrm{~cm}^{-1}$, which are D and $\mathrm{G}$ bands of hydrogenated amorphous carbon (Chen et al. 2007). This ore bed contains also traces of aromatic hydrocarbons $\left(825 \mathrm{~cm}^{-1}\right)$, and skeletal stretching of $\mathrm{C}=\mathrm{C}$ and $\mathrm{C}=\mathrm{O}$ molecules. Bands of aliphatic hydrocarbons occur at 1000-1280 $\mathrm{cm}^{-1}$ (Okolo et al. 2015) (samples 4B, 7, 10, 31), $1300-1390 \mathrm{~cm}^{-1}$ represents $\mathrm{CH}_{3}$ (Jehlička et al. 2009), and $1487 \mathrm{~cm}^{-1}$ refer to $\mathrm{CH}_{2} / \mathrm{CH}_{3}$ vibrational mode (Jehlička et al. 2009) (samples 7, 10). The band at $1518 \mathrm{~cm}^{-1}$ refers to the $\mathrm{C}=\mathrm{C}$ stretching in polyenes (sample 31 ), while $1620-1820 \mathrm{~cm}^{-1}$ show the $\mathrm{C}=\mathrm{O}$ vibration of oils (Orange et al. 1996) (sample 4B).

The organic matter of ores of Mn-2 (Urucum West Mines) (samples 75-2, 78-D1, and 75B5), contain bands of aliphatic hydrocarbons $\left(1104 \mathrm{~cm}^{-1}\right), \mathrm{CH}_{3}$, and the $\mathrm{D}$ and $\mathrm{G}$ band of hydrogenated amorphous carbon based on bands near 1320 and $1610 \mathrm{~cm}^{-1}$. The sample 75-2 contains only the D and G band of amorphous hydrocarbon, whereas sample 75-B5 contains the aromatic hydrocarbon $\left(825 \mathrm{~cm}^{-1}\right)$ bands of $\mathrm{CH}_{2} / \mathrm{CH}_{3}$ vibration $\left(1386,1469 \mathrm{~cm}^{-1}\right)$, and $\mathrm{C}=\mathrm{O}$ 563 vibration of oils $\left(1750-1800 \mathrm{~cm}^{-1}\right)$. The sample $78-\mathrm{D} 1$ has bands D and $\mathrm{G}$ of hydrogenated 564 amorphous carbon and traces of $\mathrm{CH}_{2} / \mathrm{CH}_{3}$ vibrational mode of aliphatic hydrocarbon $(1345,1362$ $565 \mathrm{~cm}^{-1}$ ). The sample of the Mn-3 ore bed (MCR Mine, sample 81) contains mostly hydrogenated 566 amorphous carbon (D and $\mathrm{G}$ bands at 1317 and $\left.1600 \mathrm{~cm}^{-1}\right)$ and traces of aliphatic (1000-1200 
$\left.\mathrm{cm}^{-1}, 1469 \mathrm{~cm}^{-1}\right)$ and aromatic hydrocarbons $\left(825 \mathrm{~cm}^{-1}\right)$. Only 60 of 1903 spectra contains organic material.

\section{DISCUSSION}

\subsection{Sedimentation age and environments}

The presence of long chain oil type in manganese layers with kremydilite indicates that temperatures were hardly larger than $90^{\circ} \mathrm{C}$, which eliminates the possibility that the Jacadigo

574 Group' rocks have been metamorphosed. This find makes it likely that the ${ }^{40} \mathrm{Ar} /{ }^{39} \mathrm{Ar}$ age of the 575 Mn-1 layer is effectively $547 \pm 3$ to $513 \pm 4 \mathrm{Ma}$, the ages of braunite and muscovite determined 576 by Piacentini et al. (2013). This age seems to be reinforced by that determined by Babinsky et al. 577 (2008), which dated detrital zircons (U - Pb SHRIMP) from a volcanic ash layer intercalated with 578 carbonate rocks of the Tamengo Formation at $543 \pm 3$ Ma.

Corumbella and stromatolite occurrences and field information published by Biondi and

580 Lopez (2017) indicate that the Santa Cruz Formation (BIFs) and the manganese layers sedimented 581 at the same time or after the Bocaina Formation; and that the ages of these rocks are about 550 582 Ma. The age of this fossil in the ironstones of the Santa Cruz Formations (Jacadigo Group) and 583 limestones of the Tamengo Formation (Corumbá Group) was estimated at ca. 550 Ma (Germs 584 1972; Grant 1990; Grotzinger et al. 1990; Hofmann and Mountjoy 2001; Bengtson 2002). Also, 585 the proposed age of this horizon was 555-542 Ma by ichnofossils, identified by Parry et al. (2017), in the Bocaina Formation.

There is no diagnostic evidence that sedimentation occurred during some glacial period or during some glaciation, as initially proposed by Urban et al. (1992). The only arguments of these authors were: (a) the presence of the granite blocks they interpreted as dropstones, without even

590 observing whether any of these blocks have faceted, friction-sectioned sides, and/or have striated

591 faces, as is typical of dropstones. These characteristics were never observed in the Urucum

592 (Trompette et al., 1998; Freitas et al., 2011; Biondi and Lopez, 2017). (b) To consider the Santa

593 Cruz Formation, with at least $400 \mathrm{~m}$ thick BIFs, as similar to the Rapitan Formation, with less than

$59410 \mathrm{~m}$ thick BIFs (Young, 1976). As the Rapitan Formation would be Ediacaran and of glacial 595 origin (Young, 1976), Urban et al. (1992) inferred that the Santa Cruz would have the same origin; 
and most subsequent authors adopted this idea. However, keeping in mind that this hypothesis is traditionally defended by many authors (e.g. Angerer et al., 2016), it should be discussed.

The last glacier related to snowball earth, and the sedimentation of Rapitan-denominated BIFs, was the Marinoan glaciation, which began at about $650 \mathrm{Ma}$ and ended at about $635 \mathrm{Ma}$. Considering all the information presented above, the Urucum's BIFs, ironstones and manganese layers sedimented about $550 \mathrm{Ma}$ ago, $85 \mathrm{Ma}$ after the end of the Marinoan and the snowball glaciations. The Gaskiers glaciation, which existed for 340,000 years (579.9 to 579.6 Ma), has occurred about $29 \mathrm{Ma}$ before the end of the Jacadigo Group sedimentation, and could hardly influence its sedimentation. It remains, therefore, to relate the formation of the Jacadigo Group with Baykonurian glaciation (547 to $545.5 \mathrm{Ma}$ ), so far recognized only in Asia and Africa (Chumakov, 2009; and Chumakov, 2011; Germs and Gaucher, 2012). We therefore propose to consider the possibility that the sedimentation of the BIFs and manganese layers of the Santa Cruz Formation occurred during the Baykonurian glaciation, which would explain the existence of what is interpreted by Urban et al. (1992), among other authors, as dropstones.

We hold the view that Mn-1 was most likely formed during the first inundation of the ancient graben by the fluvial, oxidative sediments that gave rise to the Urucum Formation. Unit Mn-1 contains predominantly siltic and sandy, ferruginous clastic rocks, cemented by microbially mediated Fe minerals (e.g., aegirine), and Mn-oxide and silicate (braunite, serandite, and hollandite). The areas of Figueirinha and São Domingos mines have a larger concentration of manganese in Mn-1, which are contained in clast-bearing massive ores. The upper Mn-1 layers in the Figueirinha and São Domingos mines, which include amygdalites, were probably deposited in the basin depocenter, where the amygdalites formed from hydrodynamic flux. Layers Mn-2 and Mn-3 formed in "offshore" (= greater depth) environments during periods of tectonic quiescence, when fine, clastic quartz fragments and other detrital sedimentation ceased.

\subsection{Mineralogical interpretations}

Microtextural evidence in all the studied samples appears as dense features, and the mineral types and embedded variable organic matter raise the microbially-mediated formation of the ore beds, which we argue occur as microbialites (MMPT). Two microbial ore forming systems are proposed as dual systems, characterized by $\mathrm{Fe}$ - and Mn-oxidizing metabolic processes (Feoxidizing bacteria (FeOB) and Mn-oxidizing bacteria (MnOB)). 
Several studies on the genesis and preservation of oil and natural gas have shown that long chain hydrocarbons are decomposed at temperatures above $90^{\circ} \mathrm{C}$ (Chilingar et al. 2005, p.138142). Preservation in Mn-2 and Mn-3 of aromatic and aliphatic hydrocarbons, $C=C$ stretching in polyenes, $\mathrm{C}=\mathrm{O}$ vibration of oils, among others, indicates that temperatures during diagenesis were low $\left(<90^{\circ} \mathrm{C}\right)$ and that syngenetic as well as diagenetic minerals were preserved, as identified by the Raman and FTIR analyses. Along with hydrocarbons, these analyses identified minerals such as birnessite and ferrhydrite, which we consider remnants of the original sedimentation, (i.e. they were not entirely destroyed during diagenesis). Remnants of syngenetic and diagenetic minerals interpreted as complex systems give a plausible series of processes and environmental formation conditions during sedimentation and diagenesis (Table 4, Fig. 15, SI 15-Table). The frequency of the minerals is different: the main minerals, such as cryptomelane, hollandite, hematite, and braunite, form the ore beds, but the moderate and minor minerals have also genetic importance. The Mn layers are the result of complex diagenetic processes and formation of diagenetic minerals, which include the components of the decomposition of cells and extracellular polymeric substance material (Fe and Mn bacteria, cyanobacteria, and other types; see Ewers 1983; Wignall 1994; Konhauser 1998; Villalobos et al. 2003; Dupraz and Visscher 2005; Dupraz et al 2009; Chan et al. 2011; Gyollai et al. 2017). Some syngenetic poorly crystallized minerals were preserved, and that serves as a starting

644 point. For a clear understanding, a short review on the most important mineral assemblages and primary minerals is needed. Many types of minerals occur, and these can be grouped as follows.

\section{formation}

Remnant syngenetic minerals are reported as microbially mediated minerals forming under obligatory oxic $(\mathrm{Mn})$ and suboxic $(\mathrm{Fe})$ conditions, with neutral and semi-neutral $\mathrm{pH}$. The 
microbially mediated $\mathrm{Mn}$ and Fe oxidation have different oxygen demand, and the diagenetic

651 zones represent different oxygen conditions. The nomination "suboxic" has a double meaning

652 which can cause discrepancies. To avoid misunderstanding, definitions are listed in Table 5. In general, Eh $>0$ represent oxic conditions, but the concentration of oxygen can be different, as shown in Table 5 and Fig. 15, and the microbially mediated processes occur at a given oxygen content. Diagenetic zonation also separates the oxic, suboxic, and anoxic zones, and the oxidizing agent is $\mathrm{O}_{2}$ in the oxic zone, $\mathrm{NO}_{3}{ }^{-}, \mathrm{MnO}_{2}$, and $\mathrm{Fe}_{2} \mathrm{O}_{3}$ in the suboxic zone, and $\mathrm{SO}_{4}{ }^{2-}$ in the anoxic zone (Berner 1980; Coleman 1985; Wignall 1994; Polgári et al. 2012ab).

\section{Table 5.}

Ferrihydrite and lepidocrocite on the Fe side, and vernadite, todorokite, birnessite, and manganite on the Mn side, are regarded as syngenetic minerals (Ehrlich 2002). Accordingly, it is

661 obvious that ore formation started with microbial Fe oxidation. That is why interpretation starts 662 with a description of the Fe system.

\section{Syngenetic Fe system}

Understanding the biochemistry of the biomat formation is a key factor in determining the type of Fe-rich biomat that may have been involved in the formation of the Urucum Mn layers, and to define the environmental conditions. There are various types of microbial metabolisms that

667 can oxidize $\mathrm{Fe}^{2+}$ in nature, which occur under varying states of oxygen-deficient conditions. Three 668 types of Fe-rich biomats are considered for the Urucum; all are neutrophilic and consistent with 669 basin conditions (Fig. 15): (1) Microbial neutrophilic, micro-aerobic Fe(II) oxidizing bacteria (pH 670 8; Eh +0.3 V) (Hallbeck and Pedersen 1990; Ehrenreich and Widdel 1994; Konhauser 1998; 671 Ehrlich 2002) supported by mineral assemblage (ferrihydrite, goethite, hematite, celadonite); (2) 672 Nitrate-reducing Fe(II) oxidizers in suboxic/anaerobic conditions (lack of filaments; Straub et al. 673 1996); and (3) Photoferrotroph metabolism in anoxic/anaerobic light-demanding conditions, 
674 which is not plausible based on mineral assemblage, which support suboxic-oxic conditions. The 675 fourth (4) type, strongly acidic, oxic metabolism is also not plausible in the Urucum basin, and 676 does not fit with the mineral assemblage. However, a further process we have to consider, is the 677 non-Fe-oxidizing microbes later overgrown by Fe oxides via microbial processes (Konhauser 678 1998). This cannot be excluded, but the homogenous Fe-precipitation on filamentous forms do not 679 support this scenario as a principal process.

680 The rhythmic developmental stages via microbial mediation is basic. Free-living Fe(II) 681 oxidizing bacteria exist in the lag and log phases (Novick 1955; Zwietering et al. 1990), and stalk 682 formation (Fe-rich biomat-mineralization) occurs during the stationary (abbrev.: stat) phase under 683 optimal conditions ( $\mathrm{pH}>6$, aerobic, cell number $>6 \times 10^{5} \mathrm{~mL}^{-1}$, low organic $\mathrm{C}$ content, $1-3$ week 684 whole microbial population growth period; e.g., Gallionella-like freshwater types and 685 Mariprofundus-like marine types) (Hallbeck and Pedersen 1990; Chan et al. 2011; Polgári et al. 686 2012a).

687 Organic biomarkers were not directly associated with Fe-rich biomat structures. Raman 688 and FTIR data show organic matter in the biomat lacework but is not diagnostic as to its type. 689 Based on these data, the diagenesis developed more in rocks represented by sample 75-2, where 690 only amorphous carbon remained in traces, and other type of organic material was consumed. 691 Preservation of organic material was best in sample 75-B5, in which organic material occurs in 692180 of 2447 spectra, and more complex organic material, like oils and aromatic hydrocarbons, 693 were detected. Sample 78-D1 (SI 3-Fig) is more altered, because only traces of complex organic 694 material were preserved, and organic material — mostly D and G bands - occur in only 60 of 3456 695 spectra. Biomarkers cannot be isolated because of multiphase microbial activity and extensive 696 diagenetic overprinting.

697 Fig. 15. 


\section{Syngenetic Mn system}

Mn-oxide formation in Mn-1 ore bed can be explained by the oxide surface catalysis model

700

701

702

703

704

705

706

707

708

709

710

711

712

713

714

715

716 advocated by Morgan (2005). Metal-oxide surfaces are able to accelerate Mn(II) oxidation by redox reactions (e.g., hematite, goethite, lepidocrocite, and manganese dioxide; Wilson 1980; Sung and Morgan 1981; Davies and Morgan 1989). Raman spectroscopy detected vernadite as poorly crystallized mineral phase in the vicinity of hematite biomat lacework (Fig. 11).

In the case of Mn-2 and Mn-3, during the development of the Mn-oxide proto-ore, the first product of microbial enzymatic $\mathrm{Mn}(\mathrm{II})$ oxidation probably was a bio-oxide (e.g., vernadite, todorokite, birnessite), similar to the experimental studies of Villalobos et al. (2003); Bargar et al. (2005); and Bodeï et al. (2007). This enzymatic Mn oxidation can be referred to as Cycle I. The demand of microbial (enzymatic) Mn(II) oxidation is obligatory oxic conditions $(>2 \mathrm{~mL} / \mathrm{L}$ dissolved oxygen). This bio-oxide is an X-ray amorphous oxide similar to $\delta-\mathrm{MnO}_{2}$ (vernadite, todorokite, birnessite; all detected by Raman), which is thought to be a disordered thermodynamically unstable 7 - $\AA$-vernadite (hexagonal phyllomanganate) containing Mn(IV) vacancy defects, with very small particle sizes $(<20 \mathrm{~nm}$ lateral dimensions), and having only two or three $\mathrm{MnO}_{2}$ layers stacked along the c-axis (Villalobos et al. 2003). A decrease in the dissolved $\mathrm{Mn}(\mathrm{II})$ appears to act as a reductant for the biogenic oxide and control the stability of secondary abiotic reaction products $\left(\mathrm{Mn}^{2+}\right.$ components in minerals of Urucum support this process). Cation binding, like Mg, supports phyllomanganate transformation to stable tectomanganate (Bodeï et al. 2007). Experimental studies showed that extracellular polymers from bacteria catalyze the adsorption of Mg on the surface of the cells (Mandernack et al. 1995). Thus, the bacterial cells not only directly oxidize $\mathrm{Mn}(\mathrm{II})$ to $\mathrm{Mn}(\mathrm{IV})$, but also, in the early stages of oxidation, influence the cation composition of the Mn-oxide mineral being produced. Mineralogical changes similar to these are likely to be commonplace in natural settings where bacterial oxidation of $\mathrm{Mn}(\mathrm{II})$ occurs 
and may liberate sorbed metal ions or alter the rates of Mn-oxide surface processes, such as the degradation of organic molecules. It is noteworthy that microbes may exploit such mineral transformation reactions to indirectly control chemical conditions in the vicinity of the cell (Mandernack et al. 1995).

A series of detailed mineralogy and micro-textures are shown in Fig. 13 (sample 75-2 from Mn-2 ore bed). The studied part is representative for syngenetic microbial Mn oxidation. The distribution of vernadite/hollandite and very early diagenetic cryptomelane and nsutite show micro-nodules with mineralized microbial colonies with embedded organic matter, which appear to support this scenario. Recent results also comport with the study of Piacentini et al. (2013) who, based on petrographic evidence, reported that cryptomelane may not be the primary Mn mineral precipitated in the Neoproterozoic ocean floor.

\subsubsection{Diagenetic minerals}

\section{Diagenetic Fe system}

According to the diagenesis of Fe-rich biomats, the microbes produce poorly ordered ferrihydrite (lepidocrocite) as a primary mineral, which transforms to more ordered minerals, such as goethite or hematite (reduced form as magnetite), within a few months or years via dissolutiondehydration processes, as mentioned before (Konhauser 1998; Schwertmann and Cornell 2007; Gyollai et al. 2015). The main Fe oxide mineral in the filaments of our samples is hematite, but Raman analyses indicate that goethite also occurs (sample 75-B5, SI 12-Fig). In Mn-1, aegirine, and in Mn-2, rare jacobsite can represent mineralized Fe-biomats. In other rare occurrences, pyrite also occurs reflecting that locally anoxic conditions existed but did not become dominant. The fossilized Fe-rich biomats were rapidly and extensively encrusted by minerals, such as dolomite and silica, similar to what has been reported by Baele et al. (2008). Amorphous silica segregation 
745 is derived by either the destruction of organic complexes or the transformation of ferrihydrite 746 (Baele et al. 2008).

Aegirine, occurring in cyclic microlaminae alternating with braunite in $\mathrm{Mn}-1$, is the diagenetic mineral form of FeOB (Fig. 10). Aegirine forms via early diagenesis from the syngenetic Fe-oxi-hydroxides (ferrihydrite) and segregated silica, and represents a more stable mineral phase. Aegirine micro-laminae represent the Fe-oxidizing microbial cycles, and braunite represents the Mn cycle in silicified and stable form, also reported by Johnson et al. (2016). This aegirine-braunite microbialite represents oxic/suboxic conditions (Listova, 1961). High-resolution the segregated silica via the transitional mineral riebeckite (Fig. 11). Riebeckite is also a common constituent in BIF with aegirine reported by Savko (2006), who proposed metamorphic formation, which does not fit with our observations. In Mn-1, aegirine forms a woven network (Fig. 11), the hematitic proforma of biomat with the segregated silica. At the contact between hematite and silica, apatite, vernadite/hollandite, and braunite occur. Similar to aegirine, braunite also consumes the segregated silica. Our results fail to fit with the hydrothermal origin of aegirine proposed for 760 Paleoproterozoic Hotazel iron-formation, South Africa (Tsikos and Moore 2005); the cyclic occurrence, worm-like consuming behavior, and also the mineral assemblage contradicts with that scenario. Comparison with other natural aegirine occurrences, however, such as authigenic aegirine in the lacustrine Green River Formation of Wyoming, U.S.A. (Fortey and Michie 1978), 764 shows a close similarity. In short, the reported authigenic formation of aegirine fits well with our 765 results, but the source of $\mathrm{Na}$ instead of volcanic activity was more probably the decomposition of 766 cell and extracellular polymeric substance organic material.

As the depth of the basin is not known, fragments of slightly lithified and re-sedimented 768 and cemented biomats occur, a shallow marine condition cannot be excluded. In such 
environments, evaporitic alkaline sodium-rich conditions cannot be ruled out and indeed, are preferred for aegirine formation. The high silica concentration favors aegirine formation instead of clay minerals (Decarreau et al. 2004, 2008), which only sporadically occur in the samples studied here (celadonite, chamosite).

Celadonite, a dominant mineral phase in the Mesozoic Úrkút Mn-deposit (Polgári et al. 2012b; 2016ab), is an Fe-mica reflecting suboxic neutral conditions. It is rare in Urucum presumably because of high silica content.

\section{Chamosite formation is favored by seawater solutions at low temperatures with a relatively} reduced $\mathrm{pH}$, a low amount of $\mathrm{SiO}_{2}$, high content of $\mathrm{Fe}^{2+}$ and $\mathrm{Fe}^{3+}$, and a relatively high amount of $\mathrm{Al}$ and $\mathrm{Mg}$. Aluminum may be donated to the system by organic matter as reported by Maliva et al. (1999) who showed that the aluminum content is greatly increased by complexation with organic acids. Low silica concentration in solution is the most important condition for lowtemperature synthesis of clay minerals, as high silica concentration in solution inhibits their formation (Harder 1976).

\section{Diagenetic Mn system}

In diagenesis, the stabilization of the syngenetic Mn oxide hydroxides proceeded and pure forms, such as pyrolusite, ramsdellite, nsutite, hausmannite, manganite, and variable-cation-bound forms (e.g., $\mathrm{Na}, \mathrm{K}, \mathrm{Ca}, \mathrm{Mg}, \mathrm{Ba}, \mathrm{Fe}$ ) such as cryptomelane, jacobsite, romanèchite, and manjiorite grew (Giovanoli 1980; Mandernack et al. 1995; Villalobos et al. 2003; Bargar et al. 2005; Bodeï et al. 2007; Johnson et al. 2016). Of note, as described by Polgári et al. (2012b), Maynard (2014), and Johnson et al. (2016), rhodochrosite can result from the sporadic activity of heterotrophic microbes during the early stages of diagenesis. Rhodochrosite is, however, only frequent in the only fully analyzed kremydilite sample shown in Fig. 8. Otherwise, these poorly mineralized cryptocrystalline mineral phases mix in a variable amount in the microlaminae as a manifestation 
793 of mineralized Mn cycles. Similarly, pyrolusite, ramsdellite, and romanèchite indicate Mn 794 precipitation via diagenesis from low-temperature pore fluids as reported by Rajabzadeh et al. 795 (2017). microbial forms

Harder (1978) noted that “...the silica content of sedimentary iron ores is found in quartz 799 and different iron-containing clay minerals. Chamosite, greenalite, cronstedtite, nontronite, 800 glauconite, and thuringite are common minerals in sedimentary iron ores. In general, all these 801 minerals are extremely fine-grained." We find that the formation of Mn-1 manganese ore in 802 Urucum influenced and changed this general protocol, despite the observation of quartz, local Fe 803 mica, and Fe clay. Highly alkaline pore water conditions in diagenesis (accompanied by elevated 804 Na content) caused aegirine precipitation instead of smectite (Decarreau et al. 2004, 2008). Low 805 silica content and $\mathrm{Si} / \mathrm{Fe}$ ratio lead to chamosite formation under reduced $\mathrm{pH}$ and Eh conditions. 806 The high silica content probably influenced silica uptake of variable Mn oxide-hydroxide minerals. 807 Through stabilization caused by diagenetic processes, the Mn oxide hydroxide bound not only $\mathrm{Fe}^{2+}$ 808 and $\mathrm{Fe}^{3+}$ (e.g., jacobsite, hollandite minerals), but also silica (braunite, serandite), to form a highly 809 variable content of oxide-silicate mixed minerals. These are characterized by highly variable 810 composition. Texturally, mineral habits are strongly modulated (and perhaps templated) by 811 extracellular polymeric substances that form a network of pore spaces.

812 Braunite alternates with aegirine in $\mathrm{Mn}-1$ and also occurs in $\mathrm{Mn}-2$ representing the 813 mineralized Mn cycle (Fig. 10). The principal reasons for this viewpoint is that the system acts as 814 a diagenetic cycle owing to the fact that in $\mathrm{Mn}-1$ an active oxide surface catalyst is likely 815 responsible for the mineral assemblage, as opposed to enzymatic Mn oxidation. The interpretation 816 is that braunite formation is due to combined diagenesis, as the segregated silica needed for 
817 braunite is typical of Fe system diagenesis. The most likely formation of braunite is sedimentary

818 or early diagenetic via biogeochemically mediated processes, as proposed by Serdyuchenko (1980)

819 and Johnson et al. (2016). These studies report scenarios that are broadly similarly to our Urucum 820 samples. Micro-textural evidence (Fig. 11-12) clearly shows the formation of braunite in the

821 vicinity of hematite biomat, vernadite/hollandite, and apatite, via the consumption of segregated

822 silica. While syngenetic mineralization took place under oxic neutrophilic conditions, slightly

823 alkaline and oxic conditions were also reported for braunite formation $(\mathrm{pH}$ 9.5-9.9; Eh $+0.43 \mathrm{~V}$;

824 Listova 1961); this comports well with our scenario.

825 Serandite, as an oxide-silicate mineral, also belong to this process (empirical composition

826 of hollandite also can contain $\mathrm{Si}$ ). The relationship between serandite and braunite is documented

827 by our Raman profiles (Fig. 10). Jacobsite can be interpreted as the transitional form between Mn 828 and Fe oxides. substance, ions that were previously bound on their surfaces release $\mathrm{Ca}, \mathrm{Mg}, \mathrm{Na}, \mathrm{K}, \mathrm{P}, \mathrm{S}, \mathrm{Si}, \mathrm{Co}$, $\mathrm{Zn}, \mathrm{Ba}, \mathrm{Sr}$, and rare earth elements. These are bioactive elements in accordance with Takahashi et al. (2007), Heim (2010), Meyer et al. (2012), Gyollai et al. (2017), and Yu et al. (2019). Formation

834 of $\mathrm{CO}_{3}{ }^{2-}, \mathrm{PO}_{4}{ }^{2-}, \mathrm{SiO}_{4}{ }^{4-}$, and $\mathrm{SO}_{4}{ }^{2-}$ anions commences and a complex transforming mineralization begins to take place, which (depending on local geochemical conditions) can result in clay mineral 836 formation, mixed carbonates, feldspar, silica, and apatite. These poorly crystallized minerals can 837 transform into more stable minerals over time (Konhauser 1998; Dupraz and Visscher 2005). The 838 various geochemical features of $\mathrm{Mn}$ ores are modulated by such syngenetic and diagenetic 839 processes. These include increased Co content compared with crustal abundance, a characteristic 840 for Urucum ores as well as the Úrkút locality (Polgári et al. 2012b; Biondi and Lopez 2017). 
841 Reaction of FeOB with Co proceeds easily, and MnOB can also oxidize Cobalt (Moffett 1990).

842 The liberalization of the cell surface-bound elements provides sources of elements e.g., in the case

843 of $\mathrm{K}$ in the formation of hollandite or Si in the case of braunite and other elements (Piacentini et 844 al. 2013).

845 Abundant quartz is common in Mn-1, which in part is attributable to the contribution of 846 detrital debris, but also represents the dominant segregated reactive silica phase (Cole and Shaw 847 1983; Fisk et al. 2006). In laboratory experiments, FeOB requires protection against concentration 848 and other types of stress, and silica is used for protection by microbes (Młoszewska et al 2018). 849 The amorphous silica can easily transform into more stable minerals, such as quartz (Herdianita et 850 al. 2000).

In unit Mn-1, a part of the segregated silica is stabilized as quartz, but the formation of 852 aegirine and braunite also consumed considerable amounts. Through combined diagenesis in Mn-2 853 and Mn-3, braunite and serandite formed, which consumed (and thus, reduced) the segregated 854 silica content. Feldspar and kaolinite/dickite also formed, and rarely, cancrinite occurs. Kaolinite minerals can form under acidic condition ( $\mathrm{pH} \mathrm{2-7)}$ and within a wide temperature range. In our Urucum samples, only kaolinite and dickite were detected in this class of minerals. Kaolinite can form at low temperatures $25^{\circ} \mathrm{C}$ (Dekoninck et al. 2018). Dickite typically forms under low pH conditions. that forms in the temperature range between 120 and $280^{\circ} \mathrm{C}$ (Eberl and Hower 1975; Inoue 1995), and its presence is not supported by our results, which favor low-temperature conditions. On the 861 other hand, the reported important role of organic matter in the formation of dickite fits with our 862 results (Maliva et al. 1999). Similar to the Al demand of chamosite mentioned above, the mobility 863 of aluminum is enhanced by complexation with organic acids. In such systems, aluminum is 
864 released and hence available for clay-mineral precipitation when the organo-aluminum complexes 865 are destabilized (Maliva et al. 1999).

866 Cancrinite is a mixed silicate-carbonate-sulfate transitional mineral, which only 867 sporadically occurs in Urucum, but nevertheless reflects the variability of diagenetic conditions. 868 Apatite can precipitate at $\mathrm{pH}$ of $7-8$ and occurs in micrometer-sized crystals in the silica-rich part 869 of BIFs. Similar apatite occurrences were noted in our samples, based on Raman and CL analyses. 870 Muscovite (hydromuscovite) is common in the studied samples and was most likely formed by the 871 diagenesis of cyanobacteria filaments in Fe-rich microbialites by the leaching of biofilm alkali 872 elements (Na, Ka, Al, Mg) (Ewers 1983; Gyollai et al. 2015, 2017).

873 Among carbonates, the occurrence of dolomite (ankerite) in Mn-1 can be considerable, and 874 strontianite is present but scarce. Barite, gypsum, and johannite belong to the sulfates that form 875 from marine sulfate and/or organic constituents. Barite, a mineral precipitating under typical oxic 876 conditions $(\mathrm{Eh}>+0.2)$ at low temperature, is considered here as oxygen supply indicator, because 877 barite occurring with hematite indicates conditions that are more oxic than occurring without 878 hematite (Hanor 2000).

879 Considering the mineral assemblage, it is clear that the initially high segregated silica 880 content did not support clay formation via early diagenesis, and silica-consuming minerals are 881 numerous, which finally resulted in a decrease in silica content, which did not support quartz 882 formation. In Mn-1, the quartz content is considerable compared with Mn-2 and Mn-3, which can 883 be interpreted by the lower amount of Mn oxyhydroxides in Mn-1. Some quartz is probably of 884 clastic origin as well as feldspar and mica, but authigenic formation of these minerals is also 885 common in microbially mediated diagenetic processes, and non-luminescent minerals belong to 886 this group (Marshall 1998; Hassouta et al. 1999) (Fig. 7). 

amounts of Mn oxides and hydroxides, which overwhelm microbial Fe oxidation.

Most of the minerals detected here have well characterized formation conditions, as summarized in Table 4. Based on mineralogy, proto-ore sedimentation and diagenesis occurred under suboxic-obligatory to oxic and semi-neutral to alkaline conditions.

\subsection{Formation of kremydilites and oblate structures} correspond to different stages of development or growth. The presence of oblate structures and pores inside and outside the kremydilites indicate that they and the sediments in which they formed were a highly soft, porous, and permeable aqueous mud, within which pore fluids and gases could 897 form and migrate out (Figs. 4A-B, E-F, G-H and Fig. 16). Gas bubbles are common accompanying 898 phases of microbial mediation, which are trapped after burial, which is also characteristic of our 899 Urucum samples (Figs. 4A-B, E-F, and G-H). Different stages of the formation of a kremydilite, 900 including oblate structures, are shown in Fig. 4. The beginning of the microbial activity inside the aqueous mud deposited in the marginal basin floor, composed mainly of birnessite, ferrihydrite, organic matter, and $\mathrm{Mn}$ and Fe oxides (Fig. 8). Organic matter becomes oxidized (Fig. 4) generating $\mathrm{CO}_{2}$ and/or $\mathrm{CH}_{4}$ and/or $\mathrm{H}_{2}$, which forms intergranular bubbles (Figs. 4A-B, E-F, and G-H) that migrate towards the surface (Fig. 16B). After the first oxidation stage of organic matter, a cluster of pores remains, constituting the nucleus zone of the kremydilite structures (Fig. 4A-B and C-D). The reactivation of microbial oxidation of organic matter generates the first concentric layer of pores (= shell) around the previously formed nucleus (Fig. 4E-F). The repetition of this 908 process can generate multiple concentric layers of pores (shells) (Fig. 4G-H), and evolve to form 909 a complex kremydilite (Fig 4 I-J) with many layers, marked by the accumulation of pores 910 concentrically organized around the nucleus, as in the kremydilite sample 48 (Figs. 4K and 8A- 
911 B). The reactivation process of microbial oxidation can cease at any time, forming kremydilites

912 with one or two concentric layers around the nucleus or repeating at different times, forming 913 complex structures with multiple concentric layers (Figs. 4I-J and K). The oblate structures, now 914 preserved in the Urucum ores, did not reach the basin floor and were preserved during diagenesis. 915 The cryptomelane needle mesh structure, the prismatic cryptomelane crystallites, and the micro916 nodules were microbialites or organominerals (Dupraz et al. 2009), and the cylindrical holes are 917 likely tube escape structures through which gas bubbles migrated from the zone of microbial 918 activity (organic matter oxidation).

919 The mineralogy of the kremydilite from sample 48 (Fig.8C-E) seems to reflect the changes 920 caused by the diagenesis of the original sediment while it was buried (Fig. 16), as defined by 921 Raiswell (1987). Burial initiated the diagenesis and ore formation (Figs. 8C-D and 16B) 922 simultaneously with successive cycles of heterotrophic microbial activity, which formed the 923 kremydilite concentric layers of cryptomelane, birnessite, ferrihydrite, rhodochrosite crystallized 924 in the nucleus zone, braunite, rhodochrosite, cryptomelane crystallized in the bottom part, and 925 ferrihydrite and cryptomelane in the upper part (Figs. 8C-D, and Fig. 16B). The complete oxidation 926 of the layer and of all the kremydilites contained therein, forming the massive Mn-2 and 3 ore 927 type, is a process that began during early diagenesis and was extended after lithification through 928 microbial mediation. The origin of the oblate form of kremydilites, with concentric layers around 929 a nucleus, is a consequence only of the oxidation of the organic matter (biomass) during diagenesis 930 and the subsequent formation of pores. This process is independent of the chemical and/or mineral 931 composition of the original sediment (but Mn reduction occurs). The original and present chemical 932 and mineral composition of kremydilites arises from: (a) the abundant sedimentation of Mn 933 oxyhydroxides via enzymatic oxidation and, to a lesser extent, of Fe oxyhydroxides and (b) the 934 changes caused by diagenesis, which transforms the sediment into different minerals, as 
manganese (Fe-)-rich biomass becomes manganese-rich sediment, then $\mathrm{Mn}(\mathrm{Fe})$-rich sedimentary rock. This is the origin of an economical Mn ore deposit. The absence of iron kremydilites in the jaspilites, similar to the Mn ore beds, shows that the formation of kremydilites was a unique process that only occurred in the Mn-rich sediments, forming a new type of manganese ore.

\section{Fig. 16.}

It was previously proposed that kremydilite formed by photoferrotroph microbial processes (photosynthetic) under anoxic conditions (Biondi and Lopez 2017), which is not in accordance with the interpretation of recent results on the mineral assemblage. Our new interpretation is that these formed in suboxic-oxic conditions and slightly alkaline $\mathrm{pH}$. To reach a plausible interpretation, as a first step, it is important to determine the formation processes of kremydilite. The mineral assemblage of the studied sample supports an early diagenetic origin, rather than syngenesis (Fig. 8). The kremydilite structure resembles both nodules and concretions; thus, to compare these structures, definitions are necessary. Nodules and concretions are very similar, and sometimes, these terms are used interchangeably. However, while concretions incorporate material of the host sediment, nodules contain solely authigenic phases (Raiswell and Fisher 2000; Jackson 2005; Baumann et al. 2016; and references therein). In our case, there are only authigenic minerals based on mineral assemblage in kremydilite and in oblate structures. Consequently, based on definition, these cannot be concretions but instead are most probably better termed nodules. The definition of a nodule is also contradictory in our case, however, as in sedimentology and geology terminology a nodule is usually defined as a small, irregularly rounded knot, mass, or lump of a mineral or mineral aggregate that typically has a contrasting composition from the enclosing sediment or sedimentary rock (Jackson 2005). This is not the case in Urucum. In general, the objects we dub "nodules" lack any internal structure except for the preserved remnants of original bedding or fossils, which is also not the case here, as kremydilite is a concentric structure 
959 (structured pore system forming "pore shells" without cement infilling, which is also a difference).

960 A further aspect is mineralogy, which differs from the typical ones occurring in nodules and 961 concretions including most commonly calcite, siderite, chert, apatite (phosphorite), anhydrite, and pyrite. In Urucum, kremydilite occurs as high-quality Mn oxide ore.

964 unique concretion-like structure, which lacks the background sediment, and the accumulated sediment is the result of successive phases of oxidation of organic matter (Fig. 4) during diagenesis (Fig. 8). Authigenic mineral formation occurs during syngenesis and early diagenesis. In this sense, kremydilite, the most characteristic structure in Mn-2 and Mn-3 ore beds, can be interpreted as a unique type of syngenetic and diagenetic structure and represent a unique type of ore (also taking into consideration Maynard (2010) and Kuleshov (2011), on ore types). This interpretation is further in accordance with the main features of kremydilites, like variable-preserved porous content, signs of gas production and migration, concentric structures, and the multiple stages of 972 development. Then again, differences, such as lack of cementation and incorporation of material 973 of the host sediment, are consequential. All things considered, this is a rare ore-type, as reported by Biondi and Lopez (2017). Yet, how did these kremydilite structures form en masse? The interpretation that we favor is that heterotrophic cell colonies randomly activated in the microbialite sediment after burial in suboxic neutral/alkaline conditions, side-by-side with lithification and stabilization of minerals 978 (Mn reduction $(\mathrm{MnR})$ and reactive organic matter decomposition via heterotrophic microbial 979 mediation can be referred to as Cycle II). Rhodochrosite is a common (dominant) component in 980 the kremydilite structure in the core zone and also in the shells, from the core to the margin (Fig. 981 8). The process probably continues only along the poorly crystallized reactive vernadite and 982 todorokite. Cryptomelane and braunite are more stable. They do not take part in the process, nor 
983 does ferrihydrite, as the system does not reach the Fe reduction zone (FeR) because of the high

984 Mn concentration and relatively low organic matter content.

Why is Urucum (Neoproterozoic, Brazil) concretionary and not laminated like in Úrkút

986 (Mesozoic, Hungary)? Much less organic matter was buried, and this fact did not lead to the

987 formation of a horizontally continuous MnR zone realizing rhodochrosite laminae. Instead, local

988 heterotrophic cell colony centers caused the formation of kremydilite in the biomat system,

989 overprinting the syngenetic lamination, causing a nodular, concretional appearance. The

990 kremydilites are most probably diagenetic and not syngenetic, as rhodochrosite is diagenetic, as

991 referred to in Polgári et al. (2012b), Maynard (2014), and Johnson et al. (2016).

992 Both FTIR and RAMAN analyses show that substances inside and outside the oblate 993 structures evolved in different ways. This is exemplified by the presence of pores in each 994 kremydilite shell, the absence of pores inside the bubbles, and the absence of micro-nodules inside 995 the oblate structures. At the contact zone of the "more" oxic outer part and "suboxic" inner part, 996 spherical enrichment of cryptomelane occurred, forming a dense margin (rim). The micro-texture 997 of this rim (and also the outer and inner part) is microbial and contain "diffusional channels" (SI 998 11-Fig).

\section{6.6. Basin development}

1000 As mentioned, unit Mn-1 follows the basin floor relief, while Mn-2 and Mn-3 occur as 1001 horizontal beds in the ironstone. This can be viewed as a special series produced by syngenetic 1002 processes via authigenic mineral accumulation, summarized according to chronology of 1003 syngenetic and diagenetic processes in Fig. 17. The ore formation commenced with flooding on 1004 porous fluvial sediments, and the ore forming fluids $\left(\mathrm{Fe}^{2+}\right.$ and $\left.\mathrm{Mn}^{2+}\right)$ infiltrated and microbially 1005 colonized the pores in a woven form, and around the clastic particles in the sediment to the depth 1006 where diffusion was active (supported by microbially mediated micro-texture, which is 
syngenetic). Initially, biomass, composed of Mn and Fe hydroxides, organic matter, manganoan

1008 and ferroan carbonate and amorphous silica, deposited on the basin floor. In the extracellular 1009 polymeric substance network, diagenetic minerals along with clastic material dominated (based on

1010 CL). The ore formation started with enzymatic Fe oxidation, as the Raman profiles of Mn-1

1011 samples prove, resulting in a well-developed biomat system. This offered oxide surface catalysis

1012 for Mn oxidation, which was not enzymatic during Mn-1 because the level of oxygen supply did 1013 not reach the obligatory oxic level (Morgan 2005). The dynamic processes affected the top zone 1014 of sediments up to the diffusion depth, which moved upward in time, forming the Mn-1 ore bed.

1015 The effect of fluvial contribution decreased via marine flooding, and the clastic 1016 contribution ceased gradually, offering excellent calm conditions for undisturbed Fe- and Mn1017 biomat formation, resulting in fine cyclic mineral lamination (mineralized biomats, microbialite) 1018 (Fig. 10, SI 12-Fig). The FeOB continued forming ironstone (Biondi and Lopez 2017), under 1019 suboxic conditions, in which oxygen supply was not favorable for MnOB. Enzymatic Mn oxidation starting as chemical nutrients $\left(\mathrm{Mn}^{2+}\right)$ were in the system, and the

1021 Mn-2 and later Mn-3 layers suddenly occurred in the Fe sediments. This made conditions more oxic and obligatory oxic. The sudden change is caused simply by the turning of oxygen supply from suboxic (dissolved oxygen-DO 0.2-2.0 mL/L) to obligatory oxic ( $\mathrm{DO}>2.0 \mathrm{~mL} / \mathrm{L})$ conditions,

1024 which is the criterion of enzymatic Mn(II) oxidation. In the background of formation of Mn-2 and $1025 \mathrm{Mn}-3$, the microbial Fe oxidation continued, as supported by the well detectable micro-lamination 1026 (cyclicity) of microminerals. The sharp contact in the field representing that horizon where Fe is 1027 forced back to local suboxic parts. The $\mathrm{Fe}^{2+}$ ascending fluid does not reach the obligatory oxic 1028 zone as a dominant contribution, because microbes oxidize it in the suboxic zone (Fig. 15). The 1029 Raman profiles clearly show that the Fe biomat system existed via all Mn ore beds, but with 1030 different intensity. Fe and Mn occurred together in an intimate form similar to Úrkút (Polgári et 
1031 al. 2012b). A similar sharp boundary (contact zone) occurs between gray (black) shale and Mn

1032 carbonate ore in Úrkút, which is also the result of change in the oxygen supply becoming 1033 obligatory oxic. This was a sensitive redox system for enzymatic Mn oxidation (Polgári et al. 1034 2016a).

1035 Summarizing the ore formation, Fig. 17 shows our model for the process that generated the 1036 massive manganese ore with kremydilites, found in the Mn-2 and Mn-3 layers of Urucum. After 1037 the formation of the ferrihydrite, birnessite, organic matter, and rhodochrosite mud-like biomass 1038 (Fig. 17A), the microbial reduction generates micro-nodules with the minerals of the original 1039 sediment in the nucleus involved by ferrihydrite (Fig. 17B), then by rhodochrosite and braunite. 1040 Late diagenetic and post-diagenetic oxidation generates Mn-2 and Mn-3 ore layers, composed of 1041 massive and/or zoned, concentric, spherical nodules, and/or zoned nodules with an eye shape (Fig. 1042 17C). The formation of kremydilites begins simultaneously or immediately after the formation of 1043 micro-nodules, in places where a cluster of microbes begins to oxidize organic matter, generating 1044 pores and producing methane, $\mathrm{CO}_{2}$, and/or $\mathrm{H}_{2}$ bubbles. This activity forms a small structure with 1045 a homogeneous and porous nucleus bound by a porous layer, which may involve the nucleus totally 1046 or partially, formed at the edge of the zone of microbial activity. The resumption of microbial 1047 activity around the same nucleus will cause greater oxidation where a greater amount of non1048 oxidized organic matter is available, generally near and on the outside of the last formed layer.

\section{$1049 \quad$ Fig. 17.}

1050 Late and post-diagenetic processes cause complete oxidation of the micro-nodules and 1051 kremydilites (Fig. 17D). Raman analyses of spherical nodules of sample 75-B2 show that central 1052 parts of micro-nodules were transformed to hollandite/vernadite and organic matter, around which 1053 cryptomelane and nsutite (pyrolusite and ramsdellite) crystallize (Fig. 17F). The minerals of the 1054 kremydilites are entirely oxidized during post-diagenetic conditions and transformed mainly into 
cryptomelane, hollandite, braunite, with little organic matter, hematite and goethite, generating the massive manganese ore of the Urucum and Mn-2 and Mn-3 layers (Fig. 17G). From time to time, coarse detrital influx disturbed the calm formation of microbial mats, resulting in turbiditic accumulation. It has been proposed that these turbidites were caused by earthquakes from rifting activity (Biondi and Lopez 2017). The most probable source of ore was hydrothermal, exhalative in submarine environment (Biondi and Lopez 2017 and references therein).

\section{CONCLUSIONS}

High-resolution Raman and AT-FTIR spectroscopy used on Mn ore samples of Mn-1, Mn-2, and Mn-3 ore beds in the ca. 550 Ma Urucum deposit yields information used to construct a selfconsistent model for the formation of these ores. This approach was used to document numerous metastable, poorly crystallized mineral phases and organic matter that represent the remnants of primary microbially mediated Mn and Fe minerals.

1. Based on mineralogy, the proto-ore sedimentation and the diagenesis of the Urucum Mn ore deposit occurred under suboxic-obligatory oxic and semi-neutral to alkaline conditions, where microbial $\mathrm{Mn}^{2+}$ enzymatic oxidation (with reactive organic matter) resulted in fine-grained accumulation of Mn oxides (Cycle I).

2. The sharp contact between the manganese and iron layers represents that horizon, where the obligatory oxic conditions facilitated the start of enzymatic Mn oxidation (Mn engine), which overwhelmed microbial Fe oxidation. The Fe biomat system existed via all Mn ore beds, but with different intensity. Fe and Mn occurred together in an intimate form.

3. Heterotrophic microbially mediated Mn reduction (Cycle II) developed only locally embedded in the form of oxide kremydilite structure, which represents a unique, new ore type. Among the kremydilite structures, regular double-microbial mineralogical cycles formed with 
1079 alternating mineralized Fe- and Mn-oxidizing bacterial activity (microbialite). Detailed study

1080 raised that kremydilite and oblate structures formed on the effect of heterotrophic cell colonies,

1081 whose activity overprinted the original lamination. The Mn reduction resulted in rhodochrosite

1082 (Cycle II) a characteristic constituent in these structures. The reason that rhodochrosite formation

1083 did not become dominant in the form of laminae is the smaller amount of organic matter

1084 accumulation, which allowed for Mn reduction via diagenesis only in random centers, resulting in

1085 diagenetic kremydilite. That is why oxic-suboxic mineral stabilization and diagenetic mineral 1086 formation became dominant.

1087 4. Mn-1 follows the basin floor relief, whereas Mn-2 and Mn-3 occur as horizontal beds in 1088 the ironstone pile. The ore formation started with flooding on porous fluvial sediments, and the 1089 ore forming fluids $\left(\mathrm{Fe}^{2+}\right.$ and $\left.\mathrm{Mn}^{2+}\right)$ infiltrated and microbially colonized the pores in a woven form, 1090 and around the clastic particles on chemical $\left(\mathrm{Fe}^{2+}, \mathrm{Mn}^{2+}\right)$ nutrients, in the sediment to the depth 1091 where diffusion was active. In the extracellular polymeric substance network, diagenetic minerals 1092 along with clastic material became dominant.

1093 5. The Fe-oxidizing bacteria continued forming ironstone, under suboxic conditions, in 1094 which oxygen supply was not favorable for Mn-oxidizing bacteria.

1096 in clast accumulation, which interrupted the fine microbial lamination. These turbidites may have 1097 been caused by earthquakes (due to rifting activity).

\section{REFERENCES}

1100 Almeida, F.F.M., 1946. Origem dos minérios de ferro e manganês de Urucum (Corumbá, Estado 1101 do Mato Grosso): Boletim da Divisão de Geologia e Mineralogia do Departamento 1102 Nacional da Produção Mineral (DNPM, Rio de Janeiro), 119, 58p. 
1103

1104

1105

1106

1107

1108

1109

1110

1111

1112

1113

1114

1115

1116

1117

1118

1119

1120

1121

1122

1123

1124

1125

1126

1127

1128

1129

1130

1131

Angerer, T., Hagemann, S.G., Walde, D.H.G., Halverson, G.P., Boyce, A.J., 2016. Multiple metal source in glaciomarine facies of the Neoproterozoic Jacadigo iron formation in the "Santa Cruz deposit”, Corumbá, Brazil. Precambrian Research 275, p. 369-393.

Babinski, M., Boggiani, P.C., Fanning, C.M., Fairchild, T.R., Simo, C.M., Sial, A.N., 2008. U-Pb SHRIMP geochronology and isotope chemostratigraphy $(\mathrm{C}, \mathrm{O}, \mathrm{S})$ of the Tamengo formation, Southern Paraguay Belt, Brazil. South American Symposyum on Isotope Geology, $6^{\text {th }}$, San Carlos de Bariloche (Argentina), p. 160.

Baele, J.M., Bouvain, F., De Jong, J., Matielli, N., Papier, S., Préat, A., 2008. Iron microbial mats in Modern and Phanerozoic environments. In Instruments, Methods, and Missions for Astrobiology XI (Vol. 7097, p. 70970N 12p.). International Society for Optics and Photonics.

Banfield J.F. and Nealson K.H. (eds), 1997. Geomicrobiology: Interactions between Microbes and Minerals. Reviews in Mineralogy 35, Mineralogical Society of America, Washington, D.C.

Bargar, J.R., Tebo, B. M., Bergmann, U., Webb, S.M., Glatzel, P., Chiu, V.Q., Villalobos, M., 2005. Biotic and abiotic products of Mn (II) oxidation by spores of the marine Bacillus sp. strain SG-1. American Mineralogist 90(1):143-154.

Baumann, L.M., Birgel, D., Wagreich, M., Peckmann, J., 2016. Microbially-driven formation of Cenozoic siderite and calcite concretions from eastern Austria. Austrian Journal of Earth Sciences 109(2):211-232.

Bazylinski, D.A., Frankel, R.B., 2003. Biologically controlled mineralization in prokaryotes. In: Biomineralization (Dove P.M., De Yoreo J.J. and Weiner S. eds). Reviews in Mineralogy and Geochemistry 54, Mineralogical Society of America and the Geochemical Society, Washington, D.C.

Bengtson, S., 2002. Origins and early evolution of predation. Paleontological Society papers 8: 289-317.

Berner, R.A., 1980. Early diagenesis: a theoretical approach, 250 pp., Princeton University Press, Princeton.

Biagioni, C., Capalbo, C, Lezzerini, M., Pasero, M., 2014. Ferrihollandite, $\mathrm{BaMn}^{4+}{ }_{6} \mathrm{Fe}^{3+}{ }_{2} \mathrm{O}_{16}$, from Apuan Alps, Tuscany, Italy: description and crystal structure. Eur. J. Mineral. 26, 171-178. 
1132

1133

1134

1135

1136

1137

1138

1139

1140

1141

1142

1143

1144

1145

1146

1147

1148

1149

1150

1151

1152

1153

1154

1155

1156

1157

1158

1159

1160

Biondi, J.C.; Lopez, M., 2017. Urucum Neoproterozoic-Cambrian manganese deposits (MS, Brazil): Biogenic participation in the ore genesis, geology, geochemistry, and depositional environment. Ore Geology Reviews 91:335-386.

Bodeï, S., Manceau, A., Geoffroy, N., Baronnet, A., Buatier, M., 2007. Formation of todorokite from vernadite in Ni-rich hemipelagic sediments. Geochimica et Cosmochimica Acta 71(23):5698-5716.

Chan, C.S., Fakra, S.C., Emerson, D., Fleming, E.J., Edwards, K.J., 2011. Lithotrophic ironoxidizing bacteria produce organic stalks to control mineral growth: implications for biosignature formation. Multidisciplinary Journal of International Society for Microbial Ecology 5:717-727.

Chen, J.Y., Schopf, J.W., Bottjer, D.J., Zhang, C.Y., Kudryavtsev, A.B., Tripathi, A.B., Wang, X.Q., Yang, Y.H., Gao, X. and Yang, Y., 2007. Raman spectra of a Lower Cambrian ctenophore embryo from southwestern Shaanxi, China. Proceedings of the National Academy of Sciences 104(15):6289-6292.

Chilingar, G.V., Buryakovsky, L.A., Eremenko, N.A and Gorfunkel, M.V., 2005. Geology and Geochemistry of Oil and Gas: Developments in Petroleum Science 52, 138-142.

Chumakov, N. M., 2009. The Baykonurian glacio-horizon of the Late Vendian. Stratigraphy and Geological Correlation 17 (4): 373-381. doi:10.1134/S0869593809040029

Chumakov, N. M., 2011. Glacial deposits of the Baykonur Formation, Kazakhstan and Kyrgyzstan. Geological Society, London, Memoirs Chapter 26, 36(1): 303307.doi:10.1144/M36.26.

Cole, T.G., Shaw, H.F., 1983. The nature and origin of authigenic smectites in some recent marine sediments. Clay Miner. 18:239-252.

Coleman, M.L., 1985. Geochemistry of diagenetic non-silicate minerals: kinetic considerations. Philos. Trans. R. Soc. Lond. A315:39-56.

Costa, M.L., Fernandez, O.J.C., Ribeiro, P.A., Silva, N.C., Poellmann, H., 2005. Contribuições mineralógicas e geoquímicas sobre a origem do minério de manganês do Morro do Urucum (Corumbá, Brasil): Simpósio Brasileiro de Metalogenia, 1th, Gramado (RS, Brasil), Abstracts, CDROM. 
1161 Dardenne, M.A., 1998. Modelo hidrotermal exalativo para os depósitos de Fe-Mn da região de corumbá, Mato Grosso do Sul: Congresso Brasileiro de Geologia, 40th, São Paulo, Brasil, Abstracts, p. 158.

1164 Davies, S.H., Morgan, J.J., 1989. Manganese (II) oxidation kinetics on metal oxide surfaces. Journal of Colloid and Interface Science 129(1): 63-77.

Decarreau, A., Petit, S., Martin, F., Farges, F., Vieillard, P., Joussein, E., 2008. Hydrothermal synthesis, between 75 and $150^{\circ} \mathrm{C}$, of high-charge, ferric nontronites. Clays and Clay Minerals 56(3):322-337.

Decarreau, A., Petit, S., Vieillard, P., Dabert, N., 2004. Hydrothermal synthesis of aegirine at 200 C. European Journal of Mineralogy 16(1):85-90.

Dekoninck, A., Moussi, B., Vennemann, T., Jamoussi, F., Mattielli, N., Decrée, S., Chaftar, H.R., Hatira, N., Yans, J., 2018. Mixed hydrothermal and meteoric fluids evidenced by unusual $\mathrm{H}$ - and O-isotope compositions of kaolinite-halloysite in the $\mathrm{Fe}(-\mathrm{Mn})$ Tamra deposit (Nefza district, NW Tunisia). Applied Clay Science 163, 33-45. https://doi.org/10.1016/j.clay.2018.07.007

Dupraz, S., Parmentier, M., Ménez, B., Guyot, F., 2009. Experimental and numerical modeling of bacterially induced $\mathrm{pH}$ increase and calcite precipitation in saline aquifers. Chemical Geology 265:44-53.

Eberl, D., Hower, J. O. H. N., 1975. Kaolinite synthesis: The role of the Si/A1 and (alkali)/(H+) ratio in hydrothermal systems. Clays and Clay Minerals 23:301-309.

Ehrenreich, A., Widdel, F., 1994. Anaerobic oxidation of ferrous iron by purple bacteria, a new type of phototrophic metabolism. Applied and Environmental Microbiology 60(12):45174526.

Ehrlich, H.L., 2002. Geomicrobiology. (4th edition). Marcell Dekker Inc., 183 - 274.

Ewers, W.E., 1983. Chemical Factors in the Deposition and Diagenesis of Banded Iron-Formation, in: A.F. Trendall and R.C. Morris (Eds.): Developments in Precambrian Geology 6, Iron formation: Facts and Problems. Elsevier, pp. 491-512. 
1192

1193

1194

1195

1196

1197

1198

1199

1200

1201

1202

1203

1204

1205

1206

1207

1208

1209

1210

1211

1212

1213

1214

1215

1216

1217

1218

1219

1220

1221

1222

Fisk, M.R., Popa, R., Mason, O.U., Storrie-Lombardi, M.C., Vicenzi, E.P., 2006. Iron-magnesium silicate bioweathering on Earth (and Mars?). Astrobiol. 6(1):48-69.

Fortey, N.J., Michie, U.M., 1978. Aegirine of possible authigenic origin in Middle Devonian sediments in Caithness, Scotland. Mineralogical Magazine 42(324):439-442.

Frei, R., Døssing, L.N., Gaucher, C., Boggiani, P.C., Frei, K.M., Bech Árting T., Crowe, S.A., Freitas, B.T., 2017. Extensive oxidative weathering in the aftermath of a late Neoproterozoic glaciation - Evidence from trace element and chromium isotope records in the Urucum district (Jacadigo Group) and Puga iron formations (Mato Grosso do Sul, Brazil). Gondwana Research 49, 1-20.

Freitas, B.T., Warren, L.V., Boggiani, P.C., Paes de Almeida, R., Piacentini, T., 2011. Tectonosedimentary evolution of the Neoproterozoic BIF-bearing Jacadigo Group, SW Brazil: Sedimentary Geology, 238, p. 48-70.

Garrels, R.M., MacKenzie, F.T., 1971. Evolution of Sedimentary Rocks. Ed. Nortom, New York.

Germs, G.J.B., 1972. New y fossil from Nama Group, South West Africa. American Journal of Sciences 272:752-761.

Germs, G.J.B.; Gaucher, C., 2012. Nature and extent of a late Ediacaran (ca. 547 Ma) glaciogenic erosion surface in southern Africa. South African Journal of Geology 115, 91102.doi:10.2113/gssajg.115.91.

Giovanoli, R., 1980. On natural and synthetic manganese nodules. In: Varentsov I.M. and Grasselly Gy. (Eds.) Geology and Geochemistry of Manganese. 1. Akadémiai Publishing House, Budapest, 159-203.

Götze, J., Plötze, M., Götte, T., Neuser, R.D., Richter, D.K., 2002. Cathodoluminescence (CL) and electron paramagnetic resonance (EPR) studies of clay minerals. Mineralogy and Petrology 76(3-4):195-212.

Graf, J.L., O’Connor, E.A., Leeuwen, P.V., 1994. Rare earth element evidence of origin and depositional environment of late Proterozoic ironstone beds and manganese ore deposits, SW Brazil and SE Bolivia: Journal of South American Earth Sciences 7, p. 115-133.

Grant, S.W.F., 1990. Shell structure and distribution of Cloudina, a potential index fossil for the terminal Proterozoic. American Journal of Sciences 290:261-294.

Grotzinzer, J.P., Bowring, S.A., Saylo, B.Z., Kaufman, A.J., 1990., Biostratigraphic and geochronology constraints on early animal evolution. Science 270:598-604. 
Gyollai, I., Polgári, M. P., Fintor, K., Popp, F., Mader, D., Pál-Molnár, E., 2015. Microbially mediated deposition of postglacial transition layers from the Neoproterozoic Otavi Group, Namibia: evidence of rapid deglaciation after the Sturtian cryogenic period. Carpathian Journal of Earth and Environmental Sciences 10(1):63-76.

Gyollai, I., Polgári, M., Fintor, K., Pál-Molnár, E., Popp, F., Koeberl, C., 2017. Microbial activity records in Marinoan Snowball Earth postglacial transition layers connecting diamictite with cap carbonate (Otavi Group, NW-Namibia). Austrian Journal of Earth Sciences 110(1): 2-18.

Hallbeck, L., Pedersen, K., 1990. Culture parameters regulating stalk formation and growth rate of Gallionella ferruginea. Microbiology 136(9):1675-1680.

Hanor, J.S., 2000. Barite-celestine geochemistry and environments of formation. Reviews in Mineralogy and Geochemistry 40:193-275.

Haralyi, N.L.E., Walde, D.H.G., 1986. Os minerais de ferro e manganês da região de Urucum, Mato Grosso do Sul, in Schobenhaus, C., and Coelho, C.E.S., ed., Principais Depósitos Minerais do Brasil. Departamento Nacional da Produção Mineral (Brasilia, Brazil), v.2, p.127-144.

Harder, H., 1976. Nontronite synthesis at low temperatures. Chemical Geology 18(3):169-180.

Harder, H., 1978. Synthesis of iron layer silicate minerals under natural conditions. Clays and Clay Minerals 26(1):65-72.

Hassouta, L., Buatier, M.D., Potdevin, J.L., Liewig, N., 1999. Clay diagenesis in the sandstone reservoir of the Ellon Field (Alwyn, North Sea). Clays and Clay Minerals 47(3):269-285.

Hasui, Y., Almeida, F.F.M., 1970. Geocronologia do Centro-Oeste brasileiro. Boletim da Sociedade Brasileira de Geologia (São Paulo), 19:5-26.

Heim, C.N., 2010. An integrated approach to the study of biosignatures in mineralizing biofilms and microbial mats. PhD thesis, Georg-August-University of Göttingen, Germany. p. 183

Herdianita, N.R., Browne, P.R.L., Rodgers, K.A., Campbell, K.A., 2000. Mineralogical and textural changes accompanying ageing of silica sinter. Mineralium Deposita 35:48-62.

Hofmann, H.J., Mountjoy, E.W., 2001. Namacalathus-Cloudina assemblage in Neoproterozoic Miette Group (Byng Formation), British Columbia - Canada oldest shelly fossil. Geology 29:1091-1094.

Inoue, A., 1995. Determination of aspect ratios of clay-sized particle. Clay Science 9(5):259-274. 
1254

1255

1256

1257

1258

1259

1260

1261

1262

1263

1264

1265

1266

1267

1268

1269

1270

1271

1272

1273

1274

1275

1276

1277

1278

1279

1280

1281

1282

1283

1284

Jackson, J.A., 2005. Glossary of geology. 5th revised and enlarged ed. ISBN 3-540-27951-2. Berlin: Springer, $900 \mathrm{p}$.

Jehlička, J., Št’astná, A., Přikryl, R., 2009. Raman spectral characterization of dispersed carbonicaceous matter in decorative crystalline limestones. Spectrochimica Acta Part A: Molecular and Biomolecular Spectroscopy 73(3):404-409.

Johnson, J.E., Webb, S.M., Ma, C., Fischer, W.W., 2016. Manganese mineralogy and diagenesis in the sedimentary rock record. Geochim. et Cosmochim. Acta 173, 210-231.

Klein, C., Ladeira, E.A., 2004. Geochemistry and mineralogy of Neoproterozoic banded ironformations and some selected, siliceous manganese formations form the Urucum district, Mato Grosso do Sul, Brazil.Economic Geology 99, p. 1233-1244.

Konhauser, K.O., 1998. Diversity of bacterial iron mineralization: Earth-Science Revs. 43:91-121.

Kuleshov, V.N., 2011. Manganese deposits: Communication 1. Genetic models of manganese ore formation. Lithology and Mineral Resources 46, 473-493. https://doi.org/10.1134/S0024490211050038

Leeuwen, P. van, Graaf, J.L., 1987. The Urucum-Mutum iron and manganese deposits, Mato Grosso do Sul, Brazil, and Santa Cruz, Bolivia. Part 1-The region's potential as an economic source of iron and manganese: Geologie en Mijnbouw 65, p. 317-325.

Leonardos, O.H., Walde, D.H.G., 1982. Sobre a estratigrafia e a gênese dos depósitos de manganês a luz do vulcanismo Jacadigo: Congresso da Sociedade Brasileira de Geociências, 27th, Salvador, Abstracts, p. 203.

Listova, L.P., 1961. Experimental studies of physic-chemical conditions of sedimentation of manganese oxides and carbonate. Ocherki Metallogen. Osadochn. Porod. Publication of the AN USSR, Moscow, 319-351.

Maliva, R.G., Dickson, J.A.D., Fallick, A.E., 1999. Kaolin cements in limestones; potential indicators of organic-rich pore waters during diagenesis. Journal of Sedimentary Research 69(1):158-163.

Mandernack, K.W., Post, J., Tebo, B.M., 1995. Manganese mineral formation by bacterial spores of the marine Bacillus, strain SG-1: evidence for the direct oxidation of Mn (II) to Mn (IV). Geochimica et Cosmochimica Acta 59(21):4393-4408.

Marshall, D.J., 1998. Cathodoluminescence of Geological Materials. Unwin Hyman, Boston, 146 pp. 
Maynard, J.B., 1983. Geochemistry of Sedimentary Ore Deposits. Ed. Springer Verlag, New York Maynard, J.B., 2010. The chemistry of manganese ores through time: a signal of increasing diversity of earth-surface environments. Economic Geology 105, 535-552. https://doi.org/10.2113/gsecongeo.105.3.535

Maynard, J.B., 2014. Manganiferous sediments, rocks, and ores, in: Treatise on Geochemistry. Elsevier, pp. 327-349.

Meyer, E.E., Quicksall, A.N., Landis, J.D., Link, P.K., Bostick, B.C., 2012. Trace and rare earth elemental investigation of a Sturtian cap carbonate, Pocatello, Idaho: Evidence for ocean redox conditions before and during carbonate deposition. Precambrian Research 192-195, 89-106.

Młoszewska, A.M., Cole, D.B., Planavsky, N.J., Kappler, A., Whitford, D.S., Owttrim, G.W., Konhauser, K.O., 2018. UV radiation limited the expansion of cyanobacteria in early marine photic environments. Nature Communications 9, 3088.

Moffett, J.W., 1990. Microbially meddiated cerium oxidation in sea-water. Nature 345 (6274):421423.

Morgan, J.J., 2005. Kinetics of reaction between $\mathrm{O}_{2}$ and $\mathrm{Mn}$ (II) species in aqueous solutions. Geochimica et Cosmochimica Acta 69(1):35-48.

Novick, A., 1955. Growth of Bacteria. Ann. Rev. Microbiol. 9: 97-110.

O'Connor, E.A., Walde, D.H.G., 1985. Recognition of an Eocambrian orogenic cycle in SW Brazil and Bolivia: Zbl. Geologie Paläontologie 1, p. 1441-1456.

Okolo, G.N., Neomagus, H.W., Everson, R.C., Roberts, M.J., Bunt, J.R., Sakurovs, R., Mathews, J.P., 2015. Chemical-structural properties of South African bituminous coals: Insights from wide angle XRD-carbon fraction analysis, ATR-FTIR, solid state 13C NMR, and HRTEM techniques. Fuel 158, pp.779-792.

Orange, D., Knittle, E., Farber, D., Williams, Q., 1996. Raman spectroscopy of crude oils and hydrocarbonic fluid inclusions: A feasibility study. The Geochemical Society, Special Publication 5:65-81.

Parry, L.A., Boggiani, P.C., Condon, D.J., Garwood, R.J., Leme, J.M., McIlroy, D., Brasier, M.D., Trindade, R., Campanha, G.A.C., Pacheco, M.L.A.F., Cleber Q. C. Diniz, C.Q.D., Alexander, G., Liu, A.G., 2017. Ichnological evidence for meiofaunal bilaterians from the 
terminal Ediacaran and earliest Cambrian of Brazil: Nature (Ecology and Evolution), v. 1(10), p. 1455-1464. DOI: 10.1038/s41559-017-0301-9.

Piacentini, T., Vasconcelos, P.M., Farley, K.A., 2013. ${ }^{40} \mathrm{Ar} /{ }^{39} \mathrm{Ar}$ constraints on the age and thermal history of the Urucum Neoproterozoic banded-iron formation, Brazil. Precambrian Research 228:48-62.

Polgári, M., Gyollai, I., 2019 Connection between biomineralization and the evolution of Earth. Frontiers in Microbiology (in press)

Polgári, M., Gyollai, I., Fintor, K., Horváth, H., Pál-Molnár, E., Biondi, J.C., 2019. Microbially mediated ore forming processes and the cell mineralization. Frontiers in Microbiology (in press)

Polgári, M., Hein, J. R., Tóth, A.L., Pál-Molnár, E., Vigh, T., Bíró, L., Fintor, K., 2012a. Microbial action formed Jurassic Mn-carbonate ore deposit in only a few hundred years (Úrkút, Hungary). Geology 4(10):903-906.

Polgári, M., Hein, J.R., Bíró, L., Gyollai, I., Németh, T., Sajgó, C., Fekete, J., Schwark, L., PálMolnár, E., Hámor-Vidó, M., Vigh, T., 2016a. Mineral and chemostratigraphy of a Toarcian black shale hosting Mn-carbonate microbialites (Úrkút, Hungary). Palaeogeography, Palaeoclimatology, Palaeoecology 459:99-120.

Polgári, M., Hein, J.R., Németh, T., Pál-Molnár, E., Vigh, T., 2013. Celadonite and smectite formation in the Úrkút Mn-carbonate ore deposit (Hungary). Sedimentary Geology 294, 157-163.

Polgári, M., Hein, J.R., Vigh, T., Szabó-Drubina, M., Fórizs, I., Bíró, L., Müller, A., Tóth, A.L., 2012b. Microbial processes and the origin of the Úrkút manganese deposit, Hungary. Ore Geology Reviews 47:87-109.

Polgári M, Németh T, Pál-Molnár E, Futó I, Vigh T, Mojzsis S.J., 2016b. Correlated chemostratigraphy of Mn-carbonate microbialites (Úrkút, Hungary). Gondwana Research 29, 1, 278-289. DOI: 10.1016/j.gr.2014.12.002.

Putzer, H., 1958. Die Kryptomelan- und Jaspelit-Lagerstätten von Corumbá im Staate Mato Grosso, Brasilien: Erzmet all, v. 11, p. 527-538.

Raiswell, R., 1987 Non-steady state microbial diagenesis and the origin of carbonate concretions and nodular limestones. In: Marshall J D. eds. of "Diagenesis of sedimentary sequences". London: Geological Society Spec Pub 36:41-54. 
Raiswell, R., Fisher, Q.J., 2000. Mudrock-hosted carbonate concretions: a review of growth mechanisms and their influence on chemical and isotopic composition. Journal of the Geological Society 157(1):239-251.

Rajabzadeh, M. A., Haddad, F., Polgári, M., Fintor, K., Walter, H., Molnár, Z., Gyollai, I., 2017. Investigation on the role of microorganisms in manganese mineralization from AbadehTashk area, Fars Province, southwestern Iran by using petrographic and geochemical data. Ore Geology Reviews 80:229-249.

Savko, K.A., 2006. Phase equilibria in rocks of the paleoproterozoic banded iron formation (BIF) of the Lebedinskoe deposit, Kursk Magnetic Anomaly, and the petrogenesis of BIF with alkali amphiboles. Petrology 14(6):567-587.

Schneider, G., 1984. Zur Mineralogie and Lagerstättenbildung der Mangan- und Eisenerzvorkommen de Urucum Distriktes (Mato Grosso, Brasilien): Frankfurter Geowiss. Arb. Serie C 1, (Frankfurt), 205 p.

Schreck, P., 1984. Geochemische Klassifikation und Petrogenese der Manganerze des Urucum Distriktes bei Corumbá (Mato Grosso do Sul, Brasilien): Frankfurter Geowiss. Arb. Serie C 1, (Frankfurt), $206 \mathrm{p}$.

Schwertmann, U., Cornell, R.M., 2007. Iron Oxides in the Laboratory: Preparation and Characterization. Wiley-VCH, $188 \mathrm{pp}$.

Serdyuchenko, D.P., 1980. Precambrian biogenic-sedimentary manganese deposits. In Geology and Geochemistry of Manganese, Vol. 2 (ed. I. M. Varentsov and G. Grasselly), Stuttgart, 61-88.

Skinner, H.C.W., 1993. A review of apatites, iron and manganese minerals and their roles as indicators of biological-activity in black shales. Precambrian Research 61, 3-4, 209-229.

Straub, K.L., Benz, M., Schink, B.,Widdel, F., 1996. Anaerobic, nitrate-dependent microbial oxidation of ferrous iron. Applied and environmental microbiology 62(4):1458-1460.

Sung, W., Morgan, J.J., 1981. Oxidative removal of Mn (II) from solution catalysed by the $\gamma$ FeOOH (lepidocrocite) surface. Geochimica et Cosmochimica Acta 45(12):2377-2383.

Takahashi, Y., Hirata, T., Shimizu, H., Ozaki, T., Fortin, D., 2007. A rare earth element signature of bacteria in natural waters? Chemical Geology 244(3-4):569-583. 
1375

1376

1377

1378

1379

1380

1381

1382

1383

1384

1385

1386

1387

1388

1389

1390

1391

1392

1393

1394

1395

1396

1397

1398

1399

1400

1401

1402

1403

1404

1405

Trompette, R., Alvarenga, C.J.S., Walde, D.H.G., 1998. Geological evolution of the Neoproterozoic Corumbá graben system (Brazil) - Depositional context of the stratified Fe and Mn of the Jacadigo Group: Journal of south American Earth Sciences 11, 587-597.

Trudinger, P.A., Swaine, D.J. eds., 1979. Biogeochemical cycling of mineral-forming elements (Vol. 3). Elsevier. pp. 1-672.

http://oriasmail.citromail.hu/dl3/?tid=7aab706ea32020b3008ea46a063058758

Tsikos, H., Moore, J.M., 2005. Sodic metasomatism in the Palaeoproterozoic Hotazel iron-formation, Transvaal Supergroup, South Africa: implications for fluid-rock interaction in the Kalahari manganese field. Geofluids 5(4):264-271.

Urban, H., Stribrny, B., Lippolt, H., 1992. Iron and manganese deposits of the Urucum district, Mato Grosso do Sul, Brazil. Economic Geology 87:1375-1392.

Villalobos, M., Toner, B., Bargar, J., Sposito, G., 2003 Characterization of the manganese oxide produced by Pseudomonas putida strain MnB1. Geochimica et Cosmochimica Acta 67(14):2649-2662.

Walde, D.H.G., 1981. Die Mangan- und Eisenvorkommen von Urucum, Mato Grosso, Brasilien: Erste Ergebnisse und ein weiteres Program, Zbl. Geol. Paläontologie 1, p. 505-513.

Walde, D.H.G., 1988. Das proterozoische Paraguay-Araguaia Orogen in West-Brasilien, Ausgehend von Untersuchungen im Raum Corumbá: Habilitationsscrift, Albert Ludwigs Universität, Freiburg, 122 p. (umpublished).

Walde, D.H.G., Gierth, E., Leonardos, O.H., 1981. Stratigraph and mineralogy of the manganese ores of Urucum, Mato Grosso, Brazil: Geologie Rundschau 70, p. 1077-1085.

Whitney, D.L., Evans, B.W., 2010. Abbreviaations for names of rock-forming minerals. American Mineralogist 95, 1, 185-187. DOI: 10.2138/am.2010.3371.

Wignall, P.B., 1994. Black shales: Oxford, UK, Clarendon Press, 124 p.

Wilson, D.E., 1980. Surface and complexation effects on the rate of Mn (II) oxidation in natural waters. Geochimica et Cosmochimica Acta 44(9):1311-1317.

Young, G.M., 1976. Iron-formation and galciogenic rocks of the Rapitan Group, Northwest Territories, Canada. Precambrian Research 3, 137-158.

Yu, W., Polgári, M., Gyollai, I., Fintor, K., Szabó, M., Kovács, I., Fekete, J., Yuansheng, Du.Y., Zhou, Q., 2019. Microbial metallogenesis of the Cryogenian manganese ore deposits in South China on micrometer scale. Precambrian Research 322, 122-135. 
Zwietering, M.H., Jongenburger I, Rombouts F.M, van Riet T.K., 1990. Modeling of the bacterial growth curve. Appl. Envir. Microbiol. 56:1875-1881.

\section{ACKNOWLEDGMENTS}

The authors thank the support of National Research, Development and Innovation Office, National Scientific Research Found No. 125060. We also thank the Companies VALE URUCUM and MCR URUCUM, for allowing us access to their mines and allowing the collection of samples of their ores. S.J.M. thanks the University of Lorraine (France) for a visiting professorship appointment during the writing phase of this paper. Comments by anonymous reviewers, as well as editorial handling by Wilson Teixeira and Eric Tohver are appreciated.

\section{FIGURE CAPTION}

Fig. 1. (A) Map showing the positions of manganese layers Mn-1 to Mn-3 and the mines of the central Urucum region (modified after Urban et al. 1992, Biondi and Lopez 2017) and, (B) $\mathrm{S}-\mathrm{S}$ ' regional geological section. The thicknesses of layers Mn-1 to Mn-3 are exaggerated by a factor of approximately ten. UTM coordinates referenced to Datum WGS 84.

Fig. 2. Stratigraphic columns made in the region of manganese and iron mines of Urucum, and sample locations. Note that the Mn-1 layer is not flat, and its shape is adapted to the basin floor while Mn-2 and Mn-3 are plane-parallel (modified after Urban et al. 1992, Biondi and Lopez 2017).

Fig. 3. Representative samples of Mn-1 (A-C), Mn-2, and Mn-3 (D-F). (A) Sample of silt, massive Mn-1 (fragments of quartz, altered feldspar, apatite, chert). (B) Clast-bearing, massive-, arkosean-, Fe-rich sample from Lower Mn-1. (C) Oblate amygdalite-bearing massive, finegrained manganese ore, with arkosean Fe-rich bands. (D-F) Kremydilite in its most developed form after diagenesis, sawed according to orthogonal planes, showing its oblate form. (D) Kremydilite sawn according to orthogonal planes, showing its oblate form. (E) The concentric organization of the several layers that constitute complex kremydilite, each concentric layer with limits marked by pores. (F) Schematic drawing of a cut kremydilite, illustrating its shape and its interior. For more representative samples see SI-3-Fig. 
Fig. 4. Different stages of development or growth of kremydilites. The text in the figure explains each stage. Bubbles: oblate structures. (A-I): photos of polished surfaces, (K) photomicrograph.

Fig. 5. Photomicrographs (reflected light) of the micro-nodules that constitute the massive parts of the Mn-2 and Mn-3 ore beds. (A-B) The larger nodules, less than $0.8 \mathrm{~mm}(3 \mathrm{~A})$ at present are formed mainly by cryptomelane and hollandite, and the matrix is hematite (Biondi and Lopez 2017). (C-D) Most micro-nodules are zoned, with a dark, porous nucleus. A, C, D photos are photomicrographs made by optical rock microscope, reflective mode, (B) is back scattered electron image by EPMA.

Fig. 6. Micro-textural features of samples (photomicrographs). Mineralized microbial biosignatures. (A) biomat (arrow, sample 36-A); (B) clastic particles (arrow, reflected light $1 \mathrm{~N}$, sample 4B); (C) mineralized microbial biosignatures (arrows, reflected light $1 \mathrm{~N}$, sample 75-2, rectangle shows enlarged area); (D) mineralized microbial biosignatures (arrows, reflected light $1 \mathrm{~N}$, sample 75-2, enlarged area on C); (E) mineralized microbial biosignatures (arrows, 1N, transmitted light, sample 7); (F) mineralized microbial biosignatures (arrows, reflected light $1 \mathrm{~N}$, sample 10); $(\mathrm{G}, \mathrm{H})$ mineralized microbial biosignatures (arrows, 1N, transmitted light, samples 32 and 36-A1). On (G) putative cyanobacteria are shown by arrow (based on similarity published by Gyollai et al., 2015 on Namibian Neoproterozoic sample).

Fig. 7. Mineralogy observed under cathodoluminescence microscopy. (A, B) Typical CL image of Mn-1 samples. Bright blue luminescence is characteristic of kaolinite group-dickite (supported by Raman spectroscopy, Götze et al. 2002); bright yellow minerals are apatite grains; the fine-grained rhodochrosite (mixed carbonate) show dull reddish (orange) luminescence color. (C, E, G) transmitted light photos by $1 \mathrm{~N}$, crossed N, and CL images of the same area of sample 7. (D, F, H) transmitted light photos by $1 \mathrm{~N}$, crossed N, and CL images of the same area of sample 10. Circles show the clastic-like but non-luminescent mineral grains.

Fig. 8. Results of the FTIR analyses of the kremydilite sample 48-B and interpretation of the results. (A-B) Image of sample (A), its concentric shells (layers) and location of the analyzed points (B). (C) Simplified proposed syngenetic minerals that build up each layer. (D) Interpretation of early diagenetic minerals detected by FTIR. Abbrev.: fehy- 
ferrihydrite; Mnox-Mn oxide and hydroxide; manji-manjiorite; todor-todorokite; crypcryptomelane; birn-birnessite; qz-quartz; rhod-rhodochrosite; Mndol-Mn-bearing dolomite; brau-braunite; goeth-goethite; spherical micro-nodules border: fluffy micronoduliferous host material.

Fig. 9. Representative part of oblate structure, sample 36-A (A-B) and mineral distribution (FTIR)(C). (A-B) Microtexture of a part of oblate structure, OM, reflective mode (1 and $\mathrm{xN}$ ), arrows show mineralized microbial signatures and diffusion channels. Abbrev: Ferriferrihydrite; Goe-goethite; Rhod-rhodochrosite; Cryp-cryptomelane; C org-organic matter; Q-quartz; Dol-dolomite; Brau-braunite; Ramsd-ramsdellite; Mx-matrix material; inhominhomogenous, italic-the component is poorly crystallized, minor.

Fig. 10. Raman profiles. Representative alternating (cyclic) mineral micro-lamination in sample 7 (Mn-1) (for detailed section see SI 12-Fig).

Fig. 11. Distribution of minerals in sample 4B (A-B) by Raman spectroscopy. Aegirine, riebeckite, braunite, quartz, hematite, apatite, hollandite/vernadite identified by Raman (A-B). Mineral abbreviations are after Whitney and Evans (2010) except bra = braunite, ver $=$ vernadite, hol $=$ hollandite.

Fig. 12. Distribution of minerals in sample 4B (A-B) by Raman spectroscopy. Braunite, hematite, apatite, quartz, and K-feldspar were identified by Raman (A-B). Mineral abbreviations are after Whitney and Evans (2010); except bra = braunite.

Fig. 13. Distribution of minerals in sample $75-2$ by Raman spectroscopy. Cryptomelane, hollandite/vernadite and nsutite (pyrolusite+ramsdellite) were identified in a micronodule, as shown in Fig. 5C-D.

Fig. 14. Composite map from the investigated oblate structure sample 36-A by Raman spectroscopy - measured areas are indicated on the picture (those places which are detailed in SI 14-Fig are in yellow color). Abbrev.: M-matrix area, 001 line-rim area.

Fig. 15. Physico-chemical vs bacterial $\mathrm{Fe}$ and $\mathrm{Mn}$ oxidation (modified after Garrels and MacKenzie 1971; Maynard 1983). Eh in Volt. Concerning NR, FeR, MnR, and SR see Table 5 and note that "suboxic" zone is used for these diagenetic zones in the sense of an oxidant agent. Sharp-turning contact between Fe and Mn mineralization as transformation to obligatory oxic conditions is estimated at $\mathrm{Eh}=0.4 \mathrm{~V}(\mathrm{DO}>2 \mathrm{~mL} / \mathrm{L})$. 
1497 Fig. 16. Kremydilite formation environment on the floor of the Urucum basin. (A) General environment schematically showing the formation of a layer such as Mn-2 or Mn-3. (B) Detail of "mud" or silica-clayey biomass sedimented on the basin floor (left side), showing the evolutionary stages that occur from sedimentation to late diagenesis (right side).

1501 Fig. 17. Cartoon showing the processes of formation of the micro-nodules, oblate structures, kremydilites, and the massive manganese ore of the Mn-2 and Mn-3 layers of Urucum. Abbrev.: CM-organic matter. Read text for details.

1504 


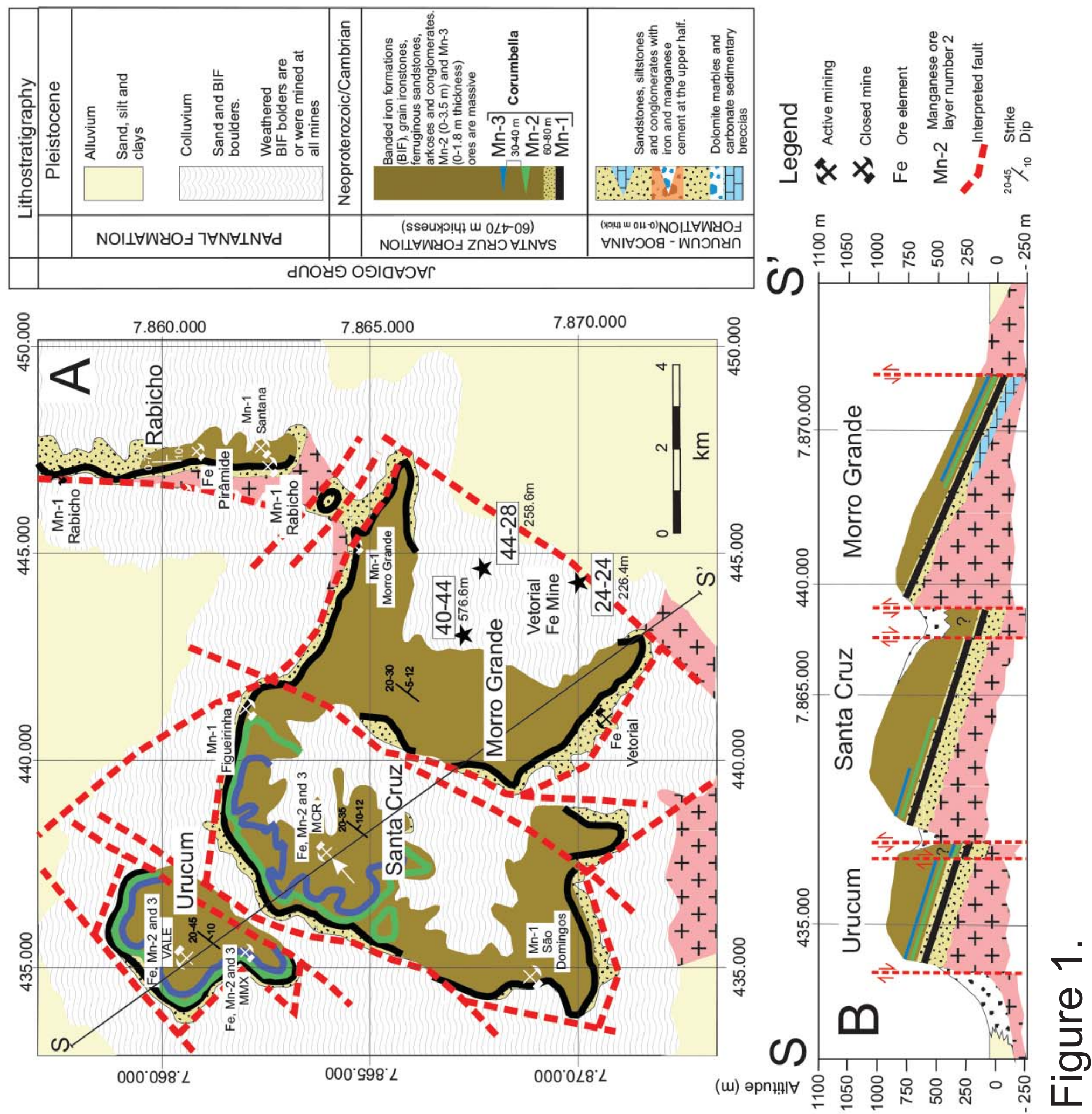




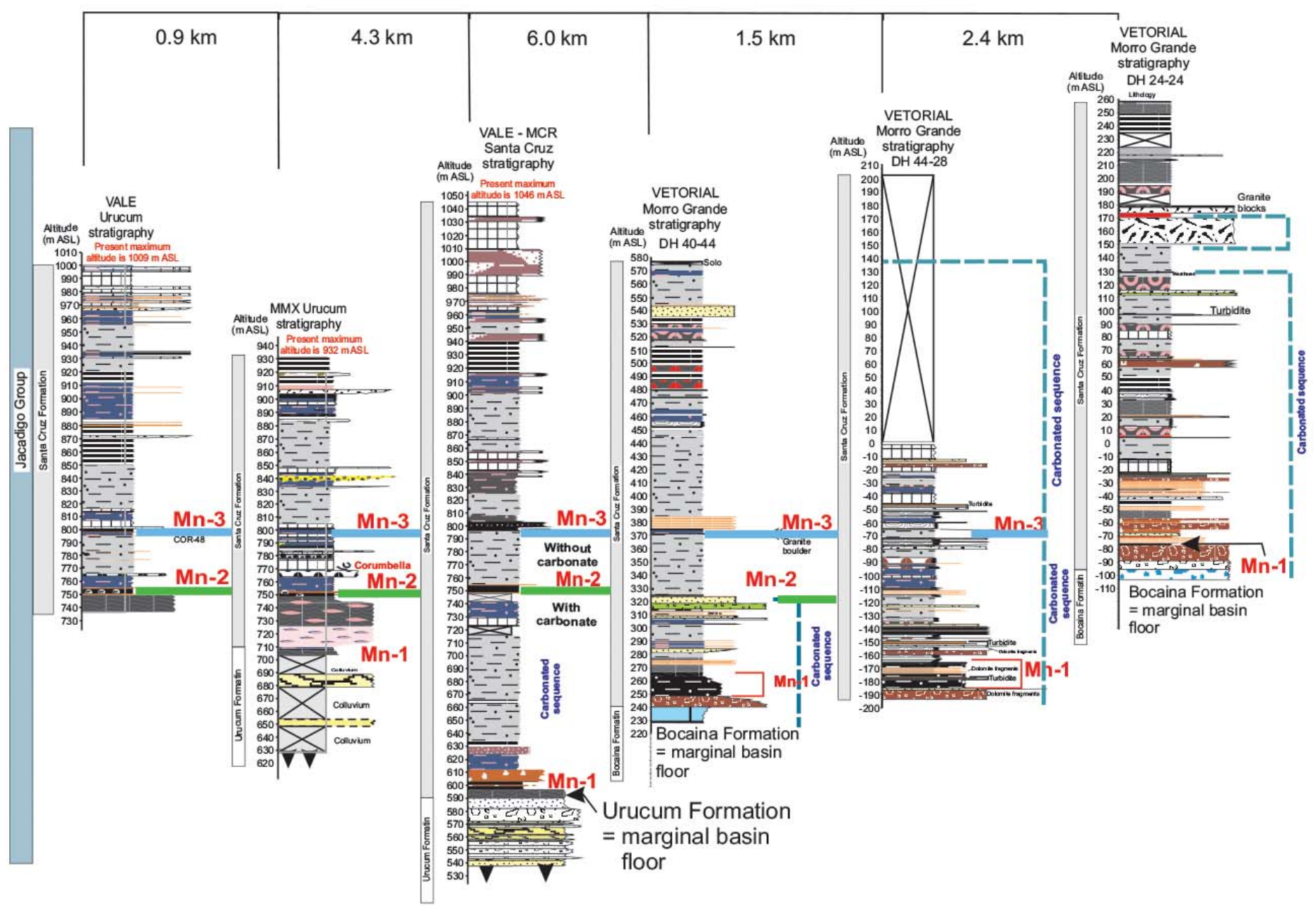

Massive jaspilite

Nodular jaspilite

Banded jaspilite - Banded BIF - Interstratification of bands of massive hematite and chert with narrow carbonate lens

Laminated jaspilite - Banded hematite

H\# intercalated with banded chert, sometimes peloidal.

$\div \div \div$ Laminated and nodular jaspilite - Laminated and peloidal stratified BIF

$\because \div$ with chert and ferroan carbonate intercalations

- $\div$ Banded and nodular jaspilite - Peloidal stratified BIF - Massive peloidal BIF, with chert and ferroan carbonate intercalations

\%.\% Nodular and laminated jaspilite

Jaspilite with embedded jasper nodules

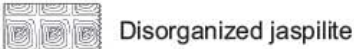

Massive hematite, gray in color, with ferruginous chert and some nodules (COR-117)

Massive hematite with minor nodules

Massive hematite with black nodules and jasper lenses

Massive manganese ore layer

$\mathrm{Mn}-1$ clastic-chemical manganese ore, with $\mathrm{qz}+\mathrm{fK}$

fragments cemented by manganese minerals

$\mathrm{Mn}-1$ clastic-chemical manganese-rich rock, with qz (+fK)

fragments cemented by manganese minerals

Jaspilite with arkosic, micro-conglomerate or sandstone layers (channels)

Ferruginous coarse/mediu/fine grained sandstone

Banded, coarse ferruginous sandstone

- Grain ironstone with intercalations or chert

lenses, reddish in color

Banded-, arkosian sandstone or micro-conglomerate with

parallel lamination

$\ldots$

Turbidite or avalanche (channels)
Intraclastic float ironstone

P.: Polimitic conglomerate/microconglomerate

with sandy hematite matrix

:-2.: Polimitic conglomerate/microconglomerate

with sandy hematite matrix and altered fragments

D:C: Polimitic, non ferruginous conglomerate

Polimitic, non ferruginous conglomerate, with dolomit2 blocks

Ferruginous-, channeled-, arkosean sandstone

Jaspilite with bioturbation

Laminated BIF with worm tracks

Sedimentary breccia

with hematite pebbles

Talus breccia with jaspilite boulders

Oolitic grain ironstone

Cherty-, grain ironstone

- - - Massive, quartz poor arkose, pinksh in color,

- . - - with some jaspilite len

$\because$ Grain ironstone

Grain ironstone

Sandstone with low angle

crossed stratification

Sandstone with crossed lamination

II Whitish and greensh dolomite with interbeded dolomite breccia

Figure 2. 

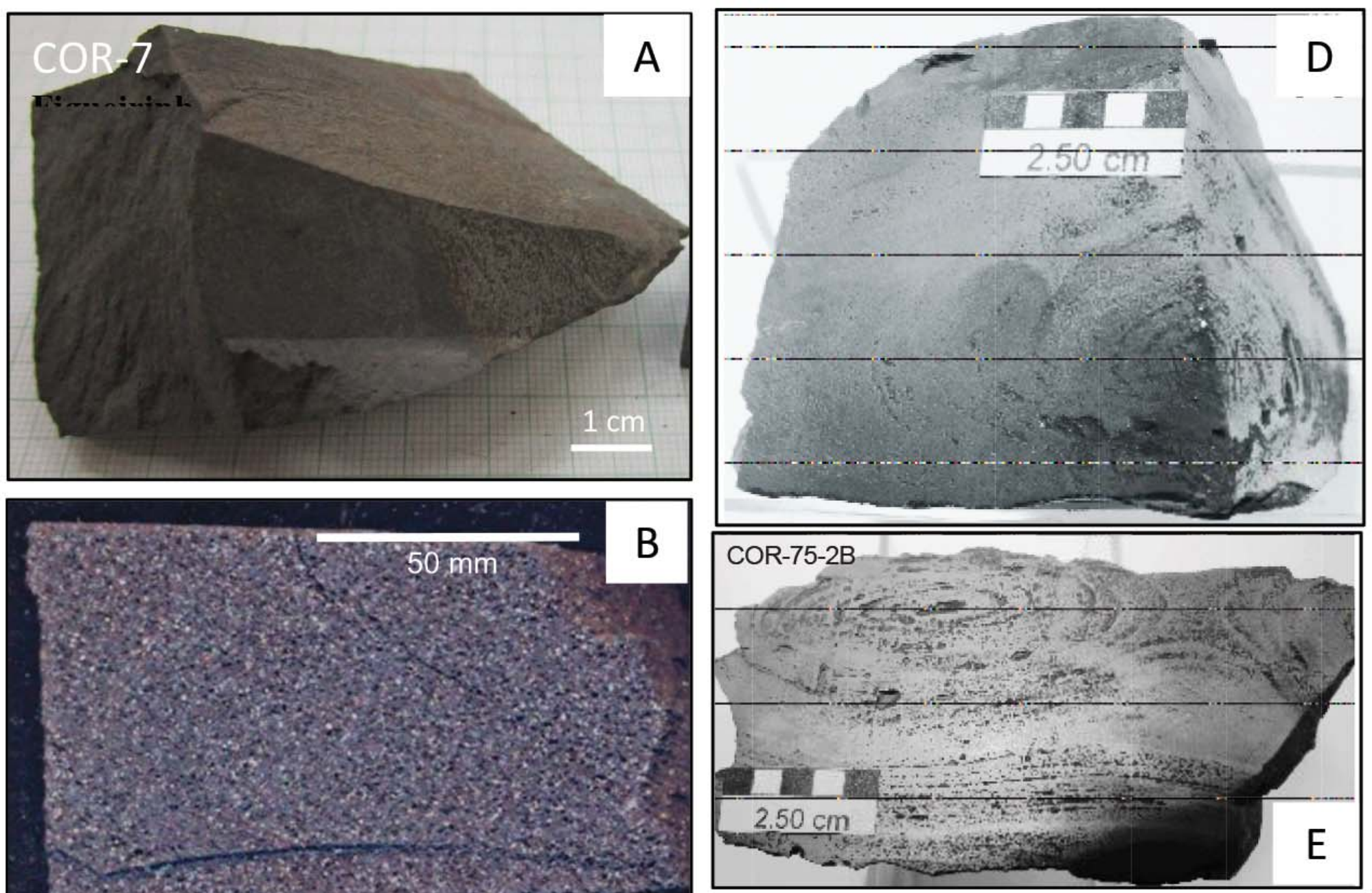

\section{COR-31}
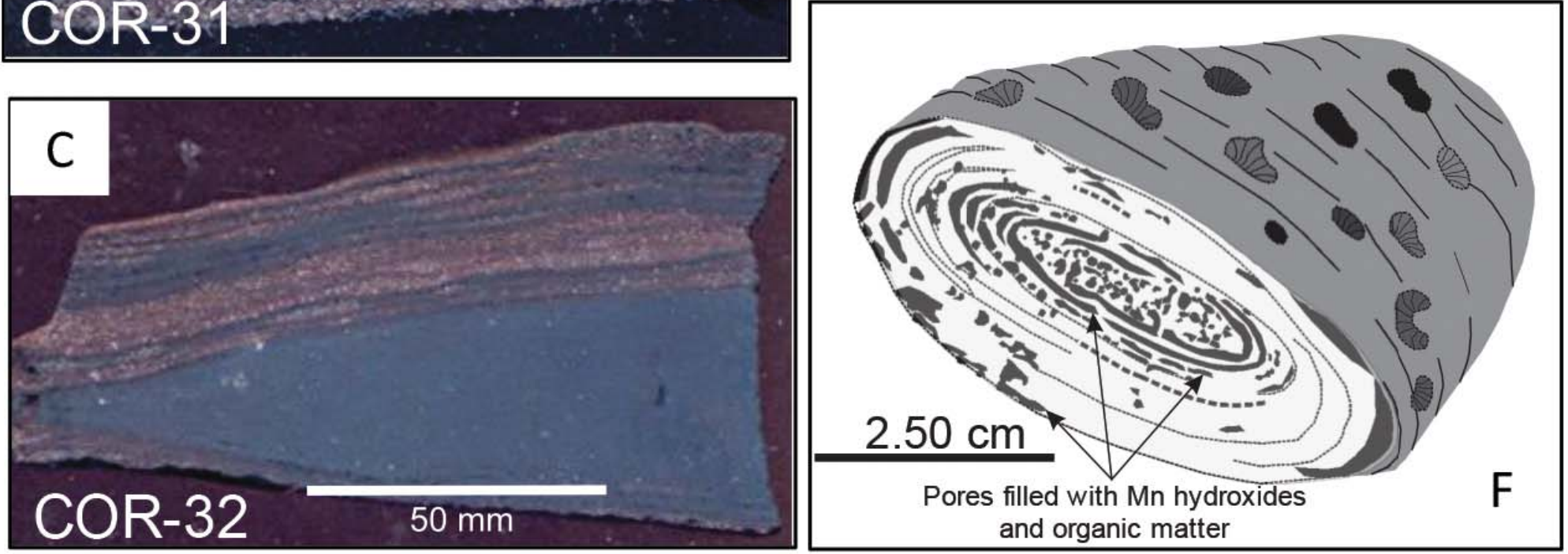

Figure 3. 

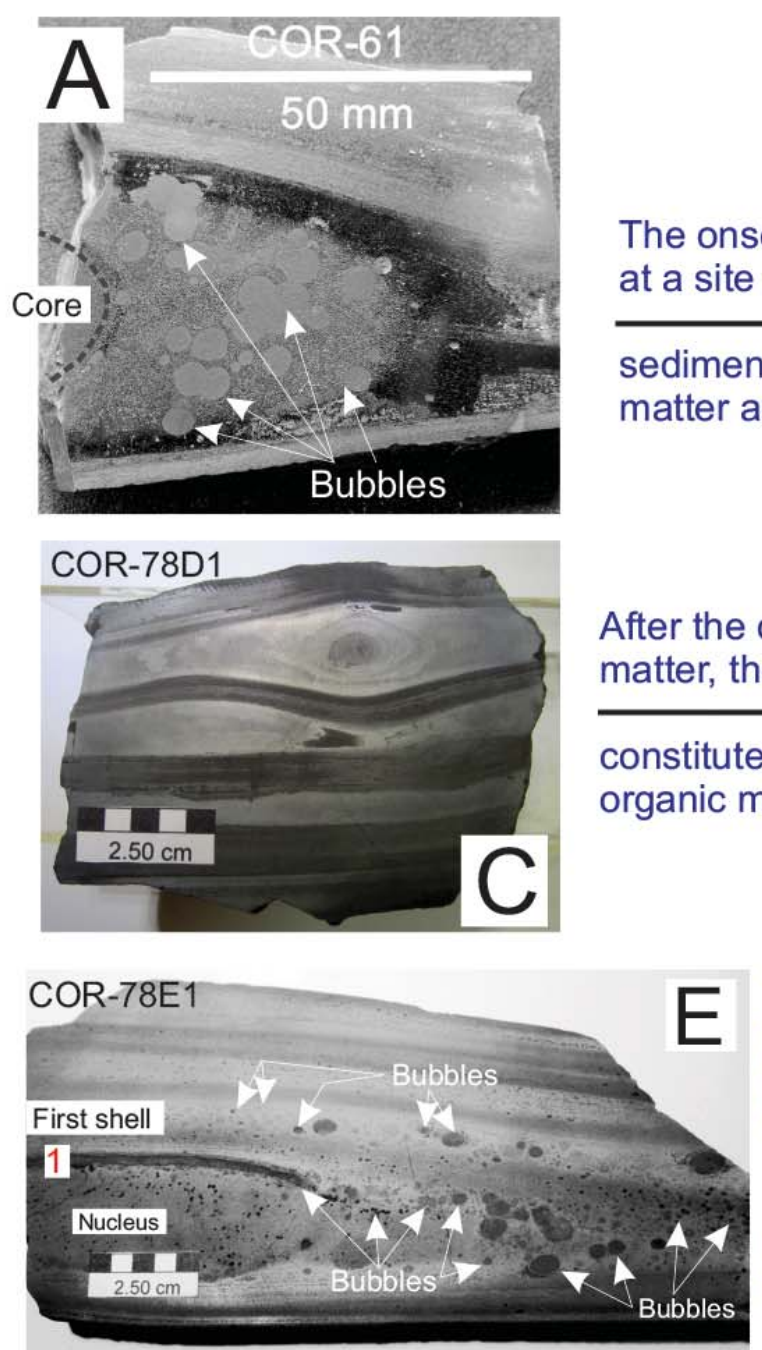

After the oxidation of the organic matter, there remains a nucleus

constituted by pores formed where organic matter was oxydized.

The onset of microbial activity at a site of the manganese

sediment layer oxidizes organic matter and generates gas bubbles.
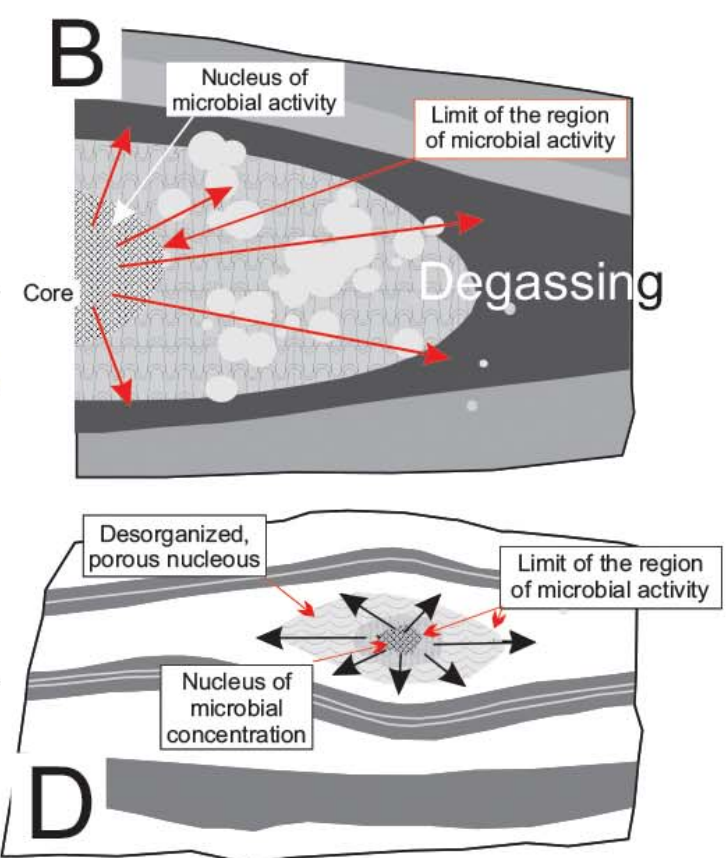

The first reactivation of the microbial activity oxidizes the organic matter existing around the nucleus generating a first layer (shell) of pores around the nucleus.

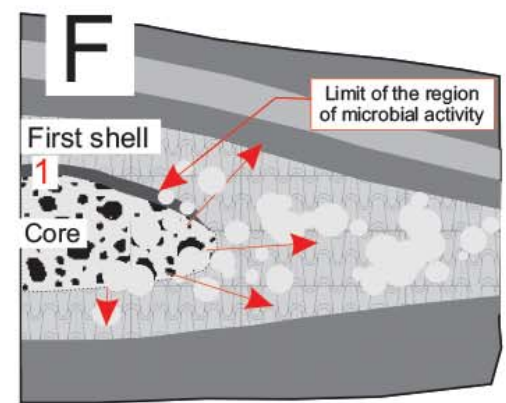

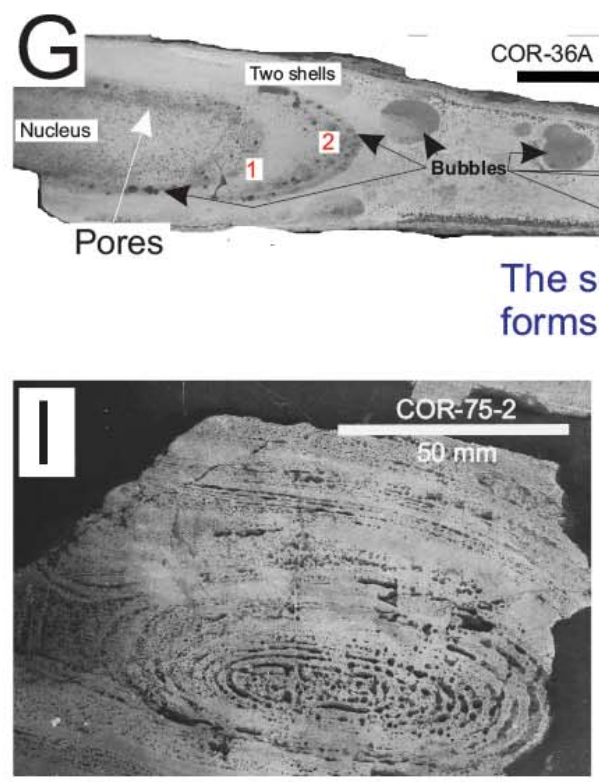

In a well-developed kremydilite, the amount of concentric layers of pores (shells) indicates how many times there was reactivation of microbial activity in that location
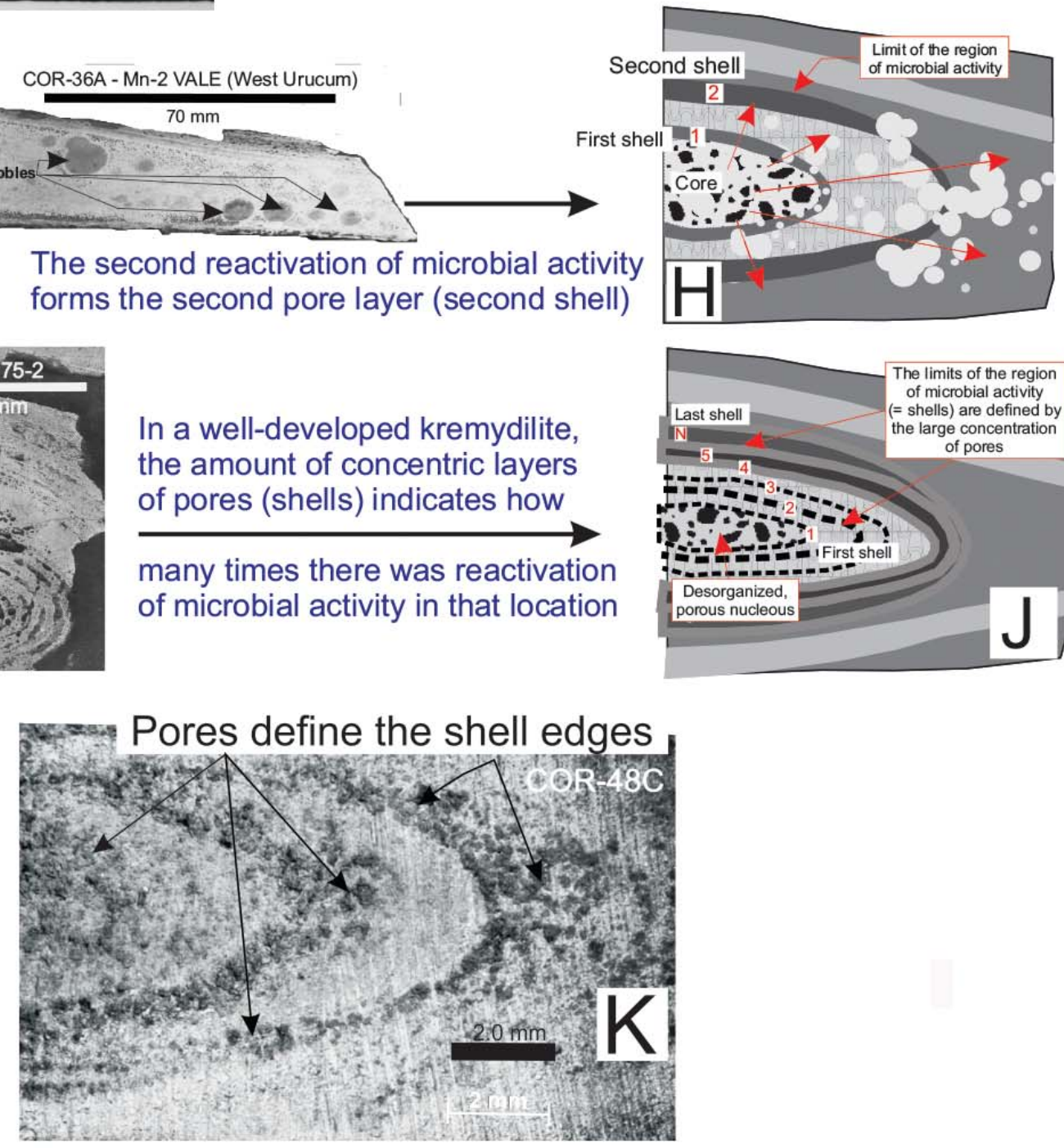

\section{Figure 4}

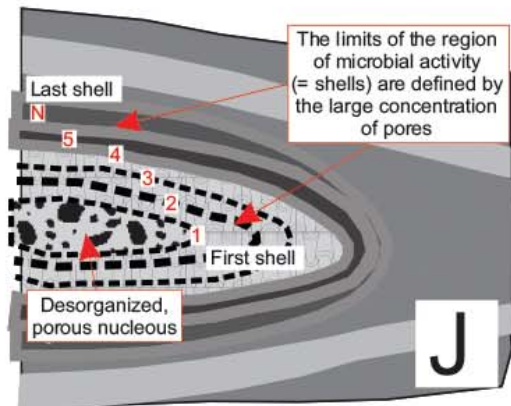



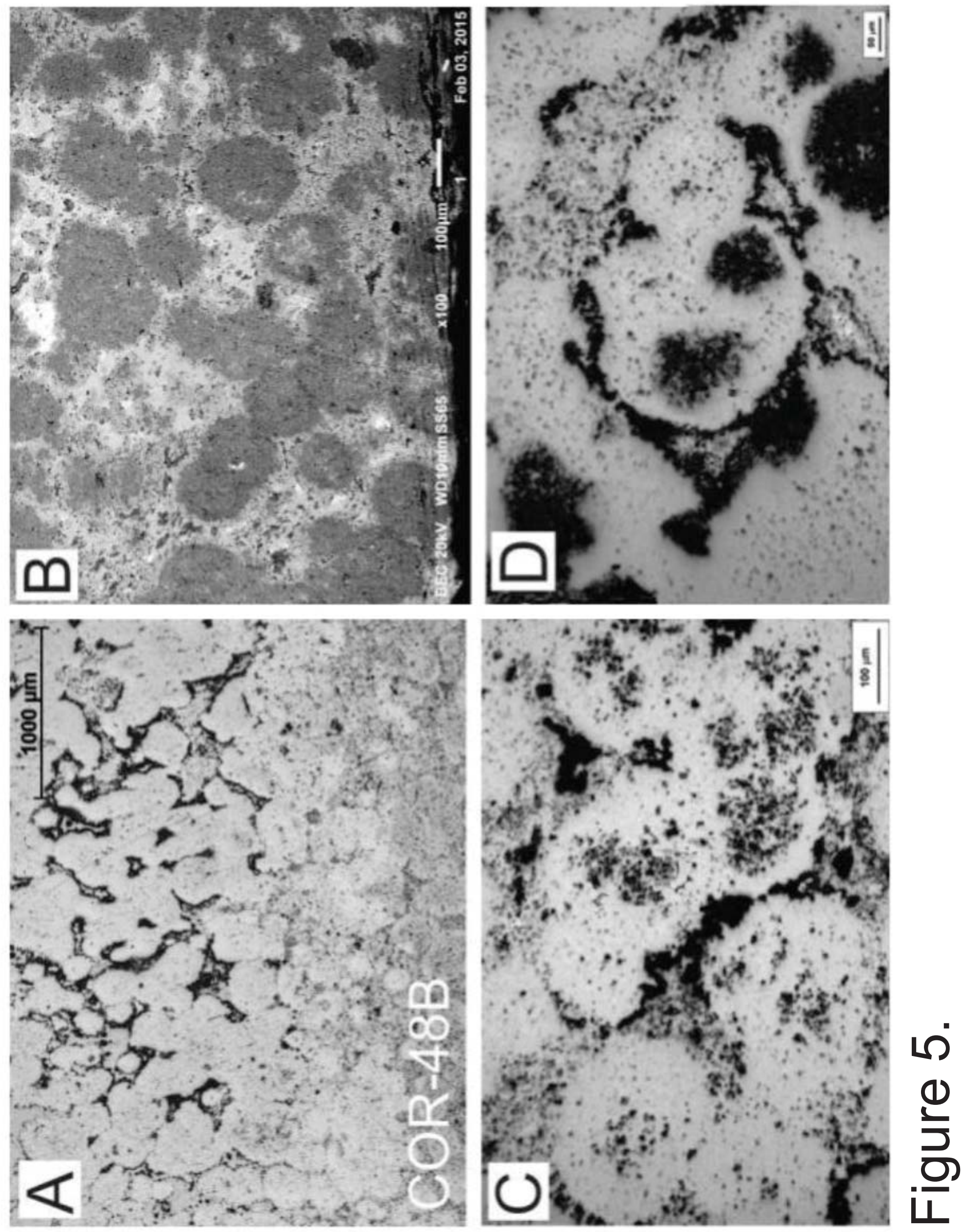

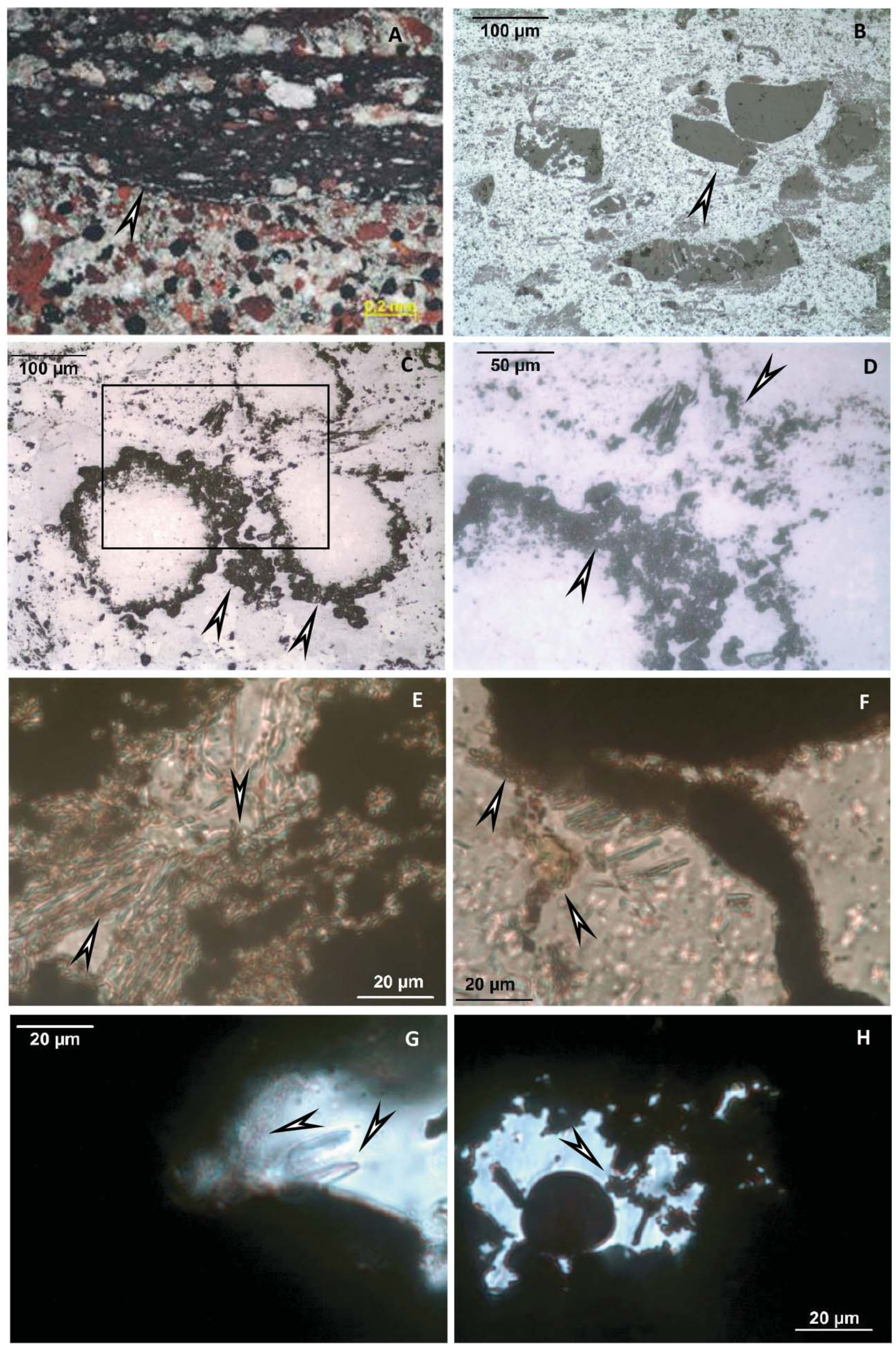

Figure 6. 


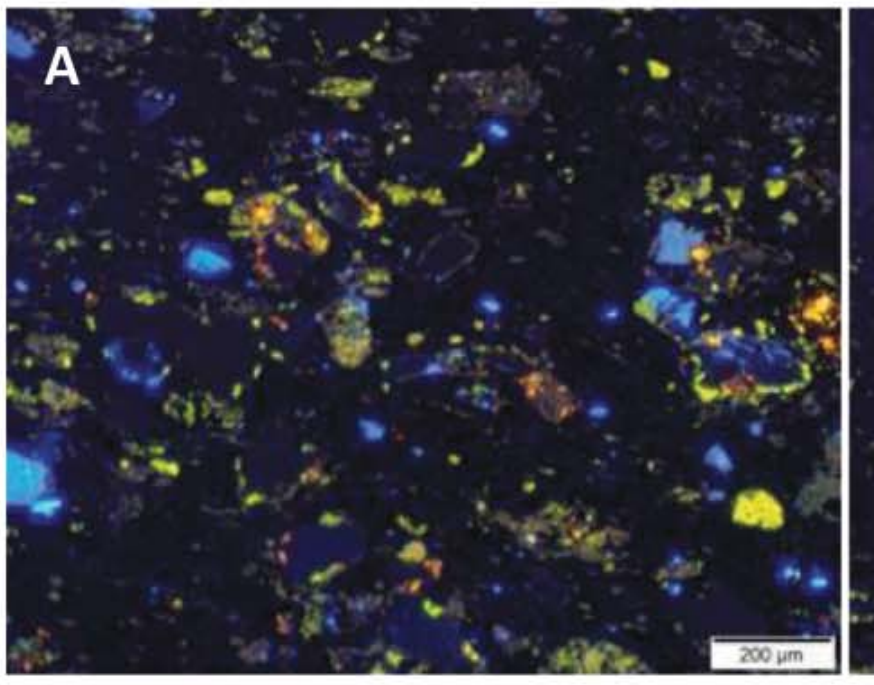

B
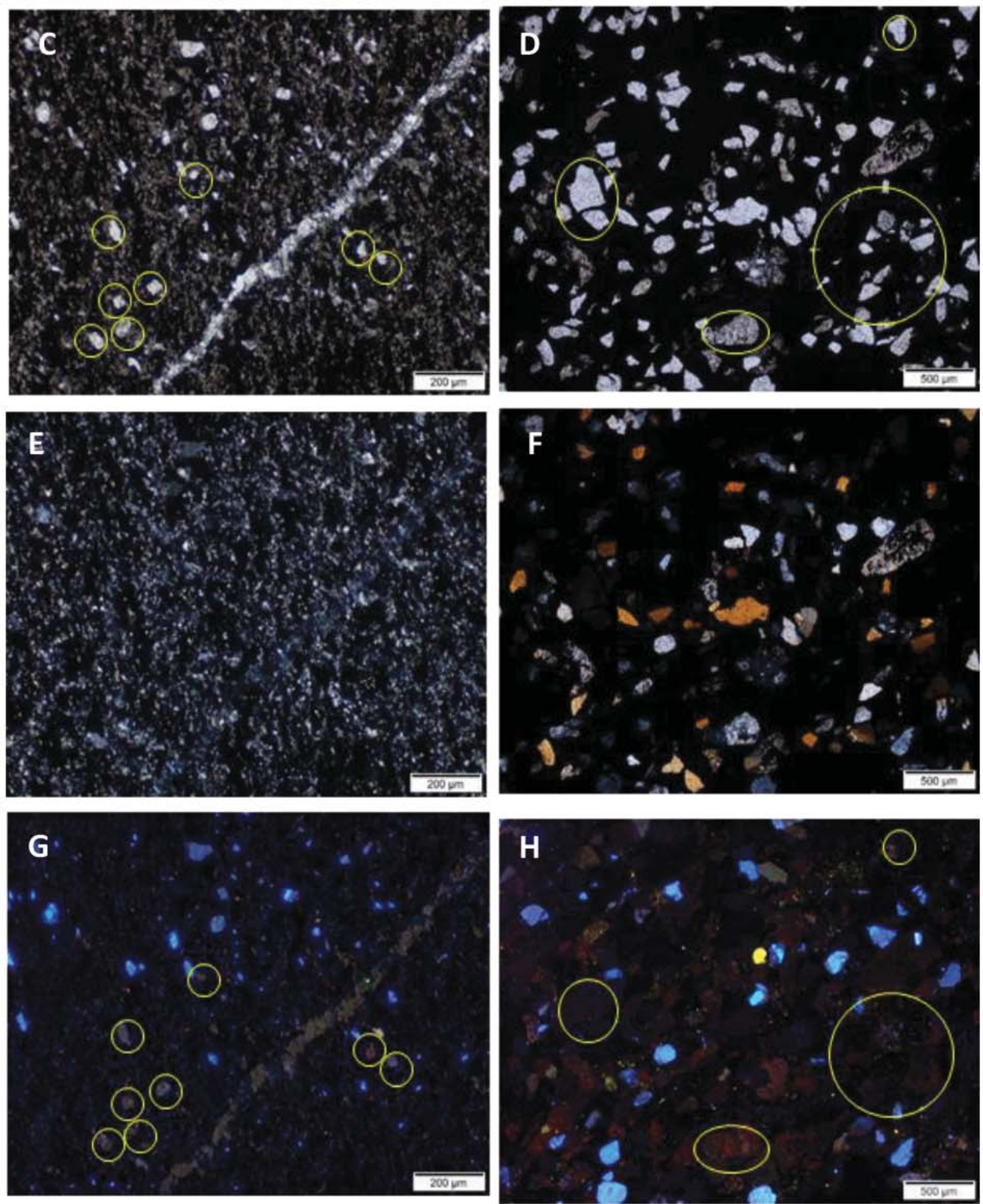

Figure 7 . 

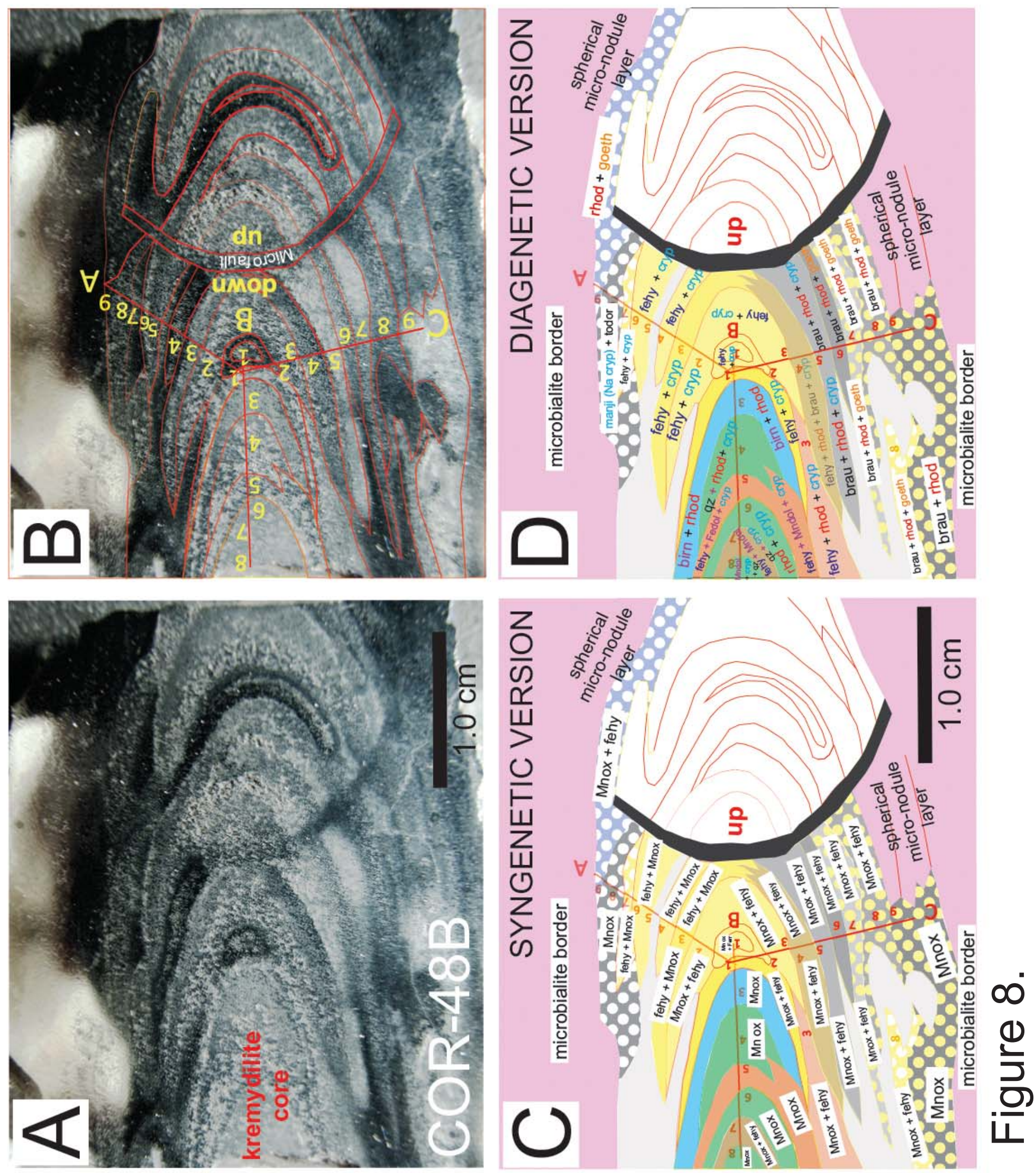

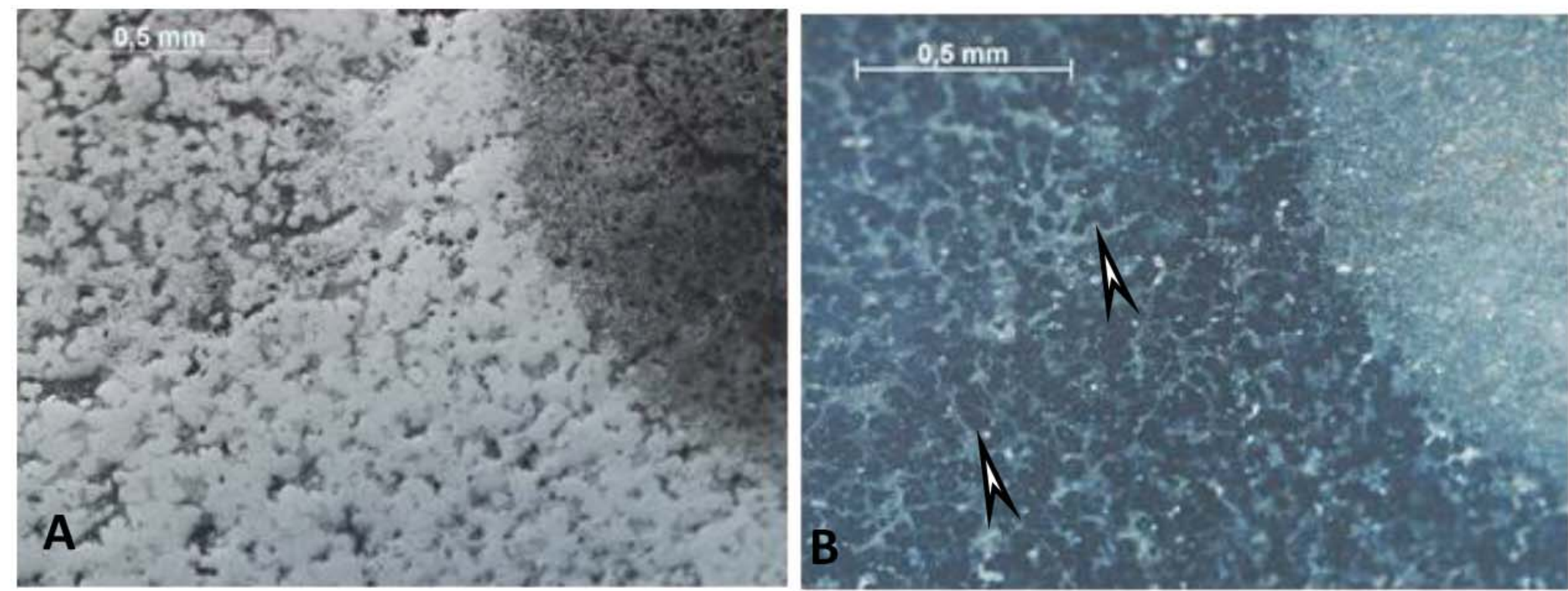

\section{C}

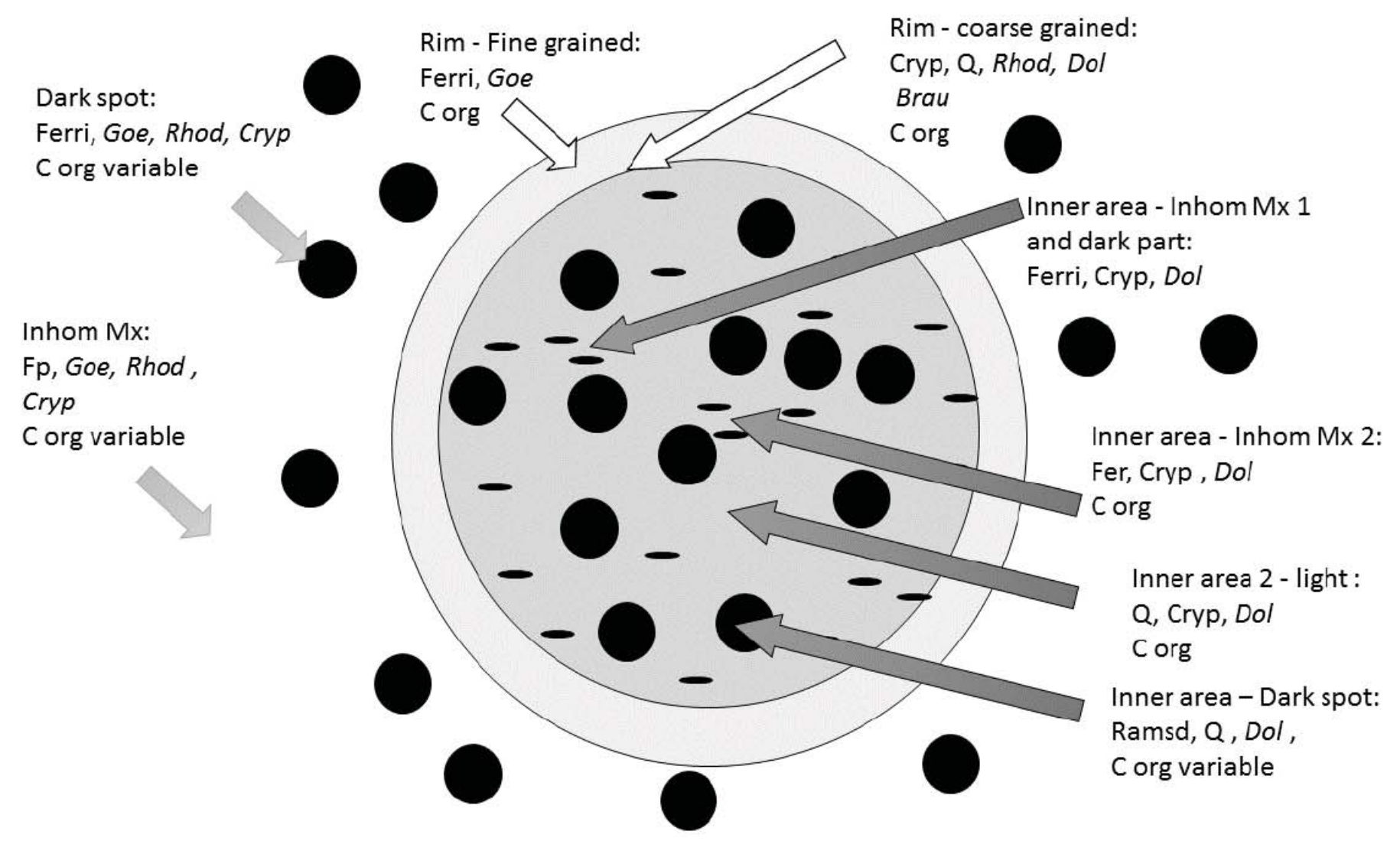

\section{Figure 9.}




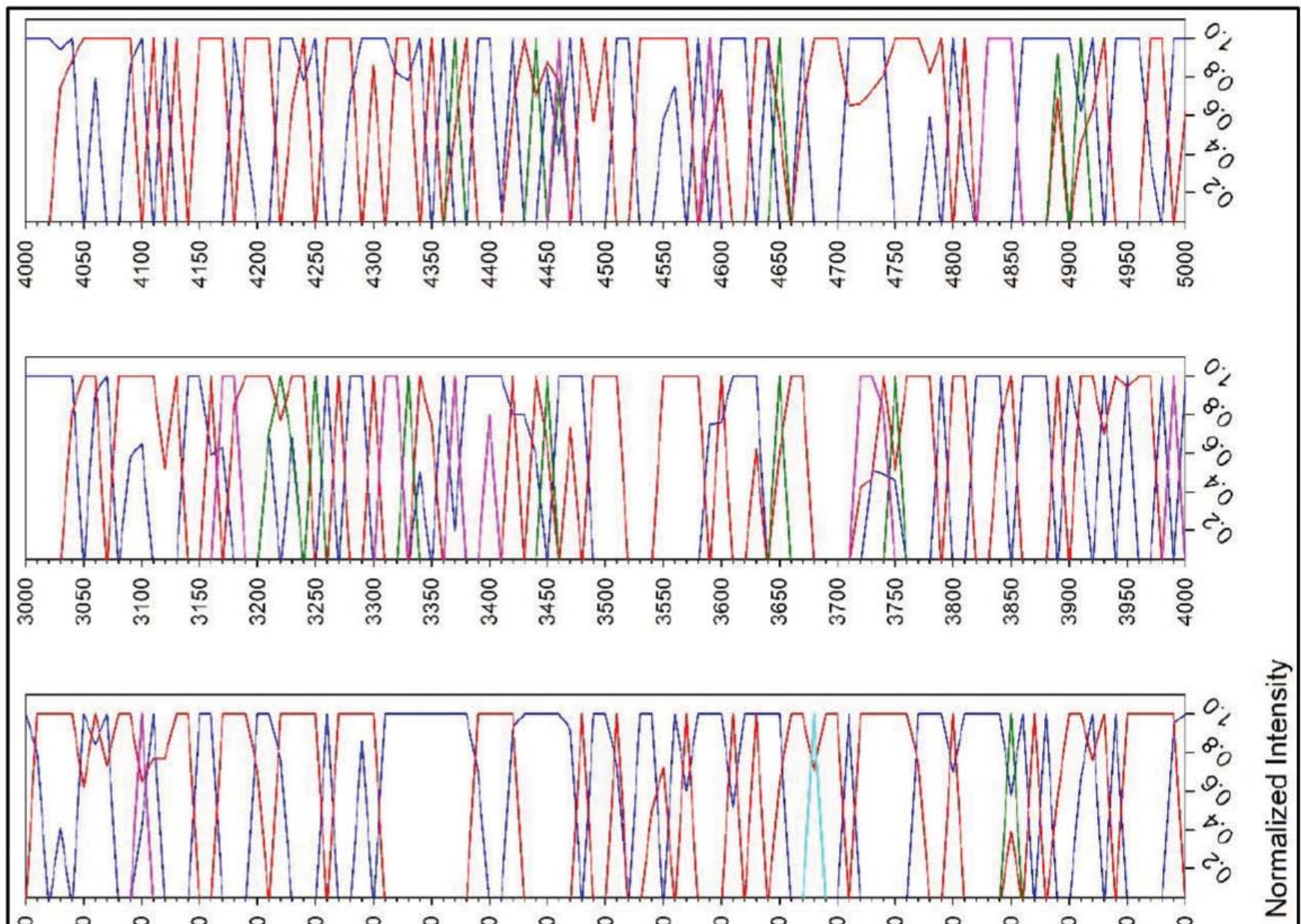

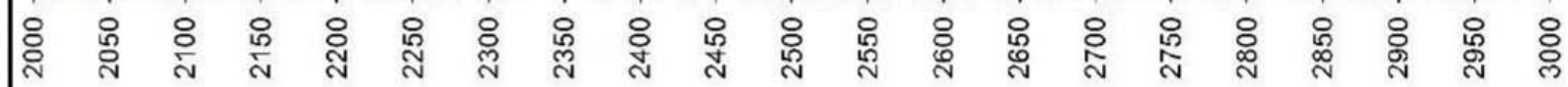

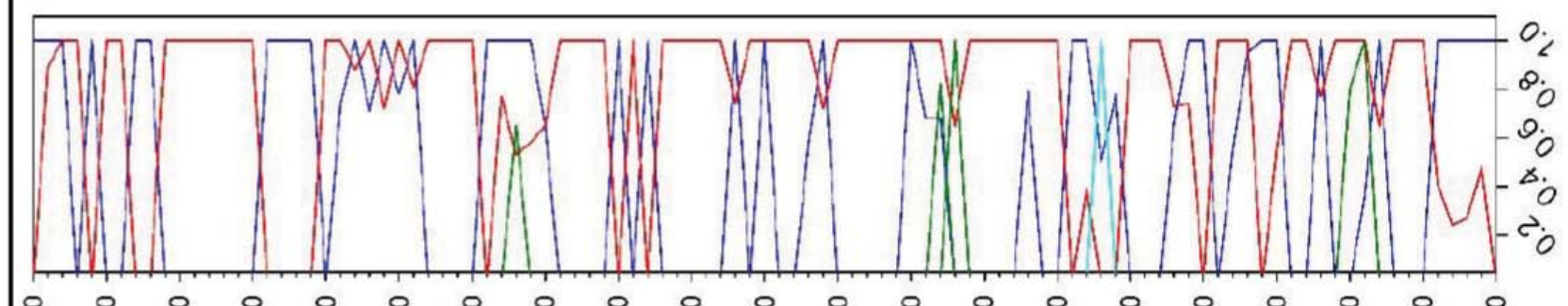

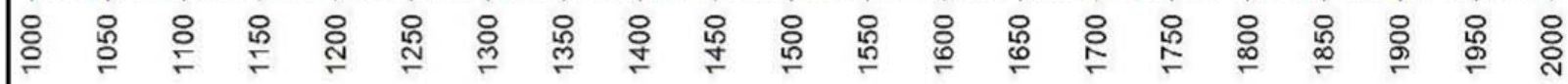

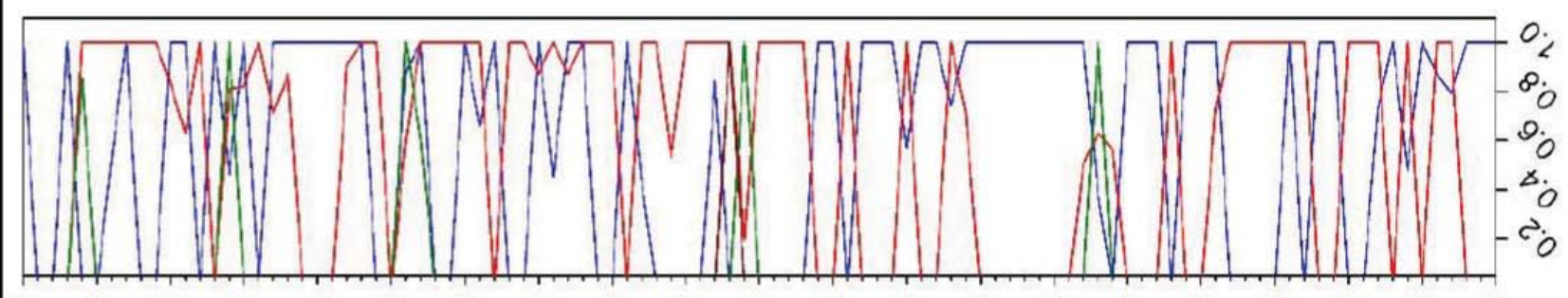

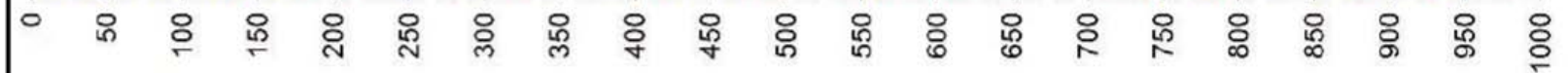

uri / әouels!
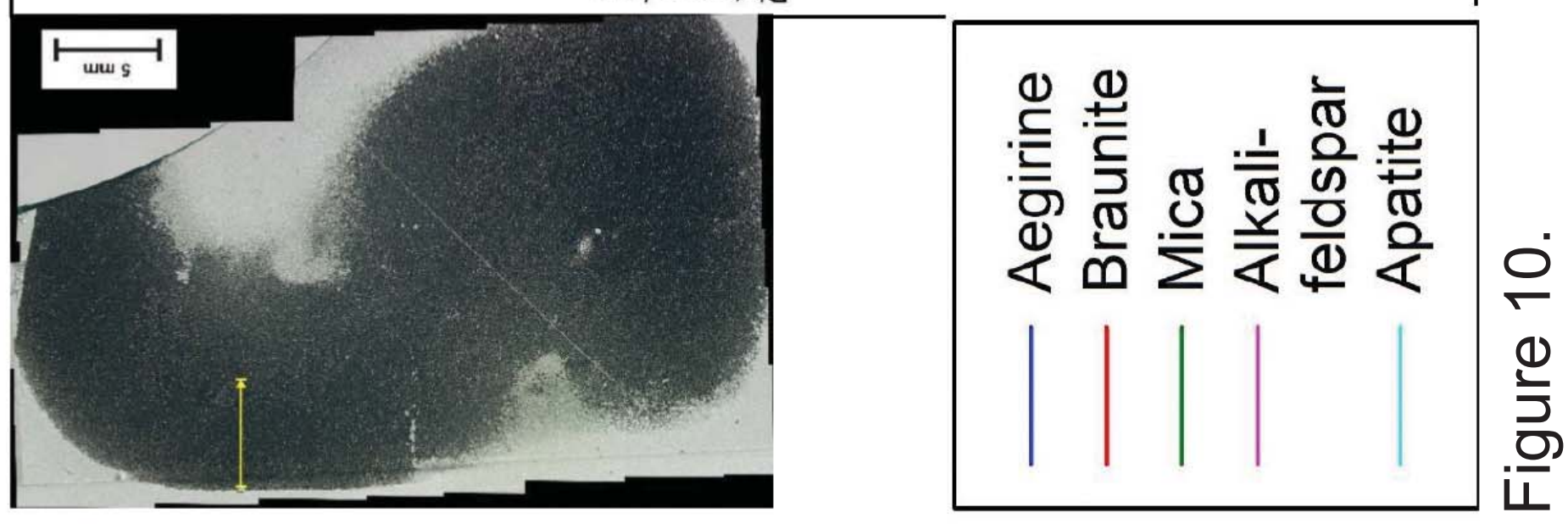


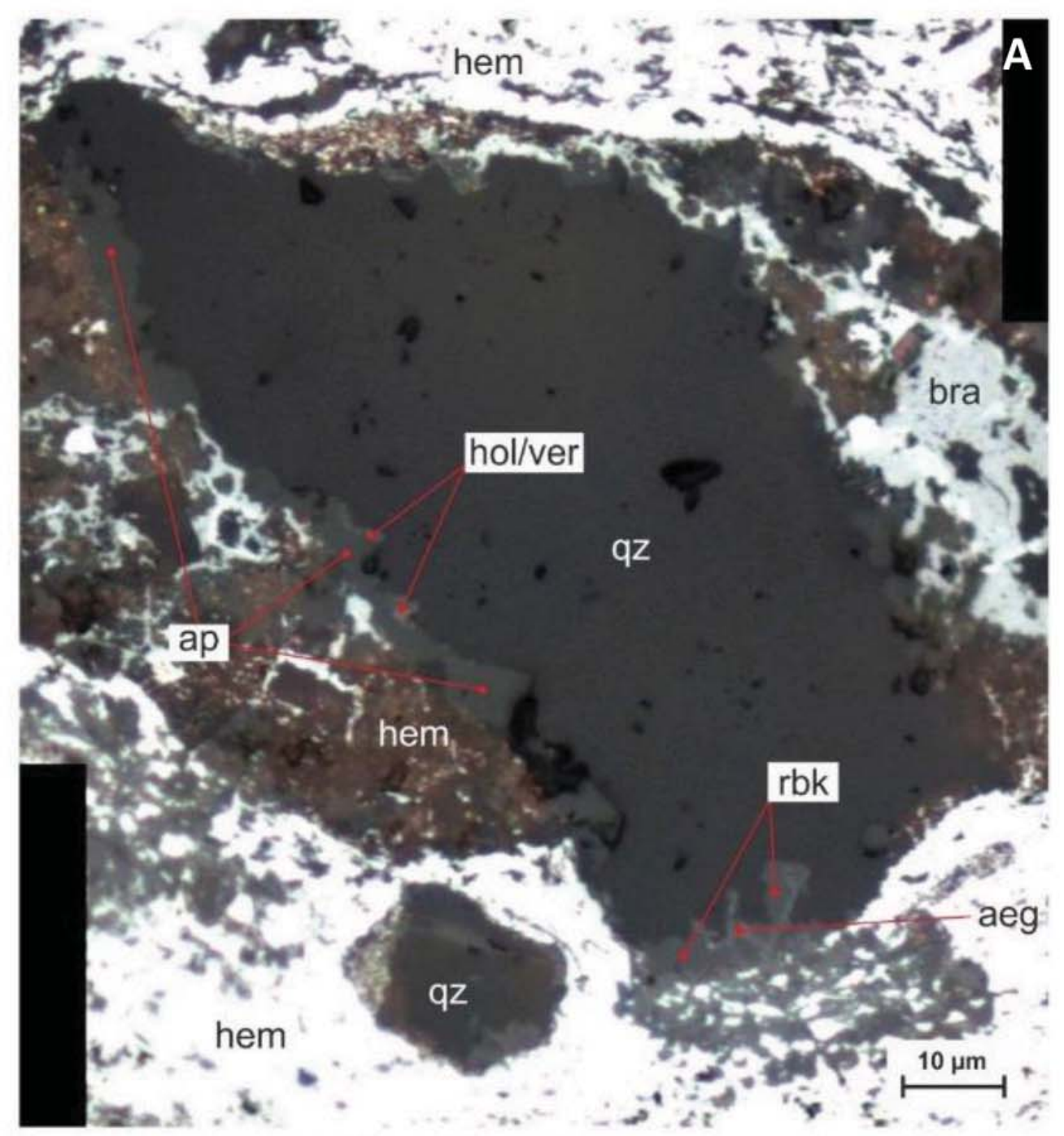

Mineral abbreviations are after Whitney \& Evans (2010), except ver: vernadite; hol: hollandite bra: braunite

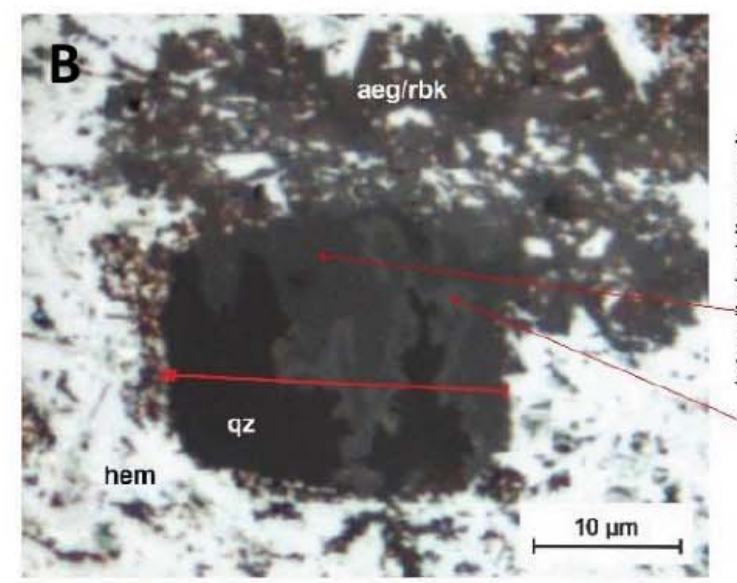

Mineral abbreviations are after Whitney \& Evans (2010)
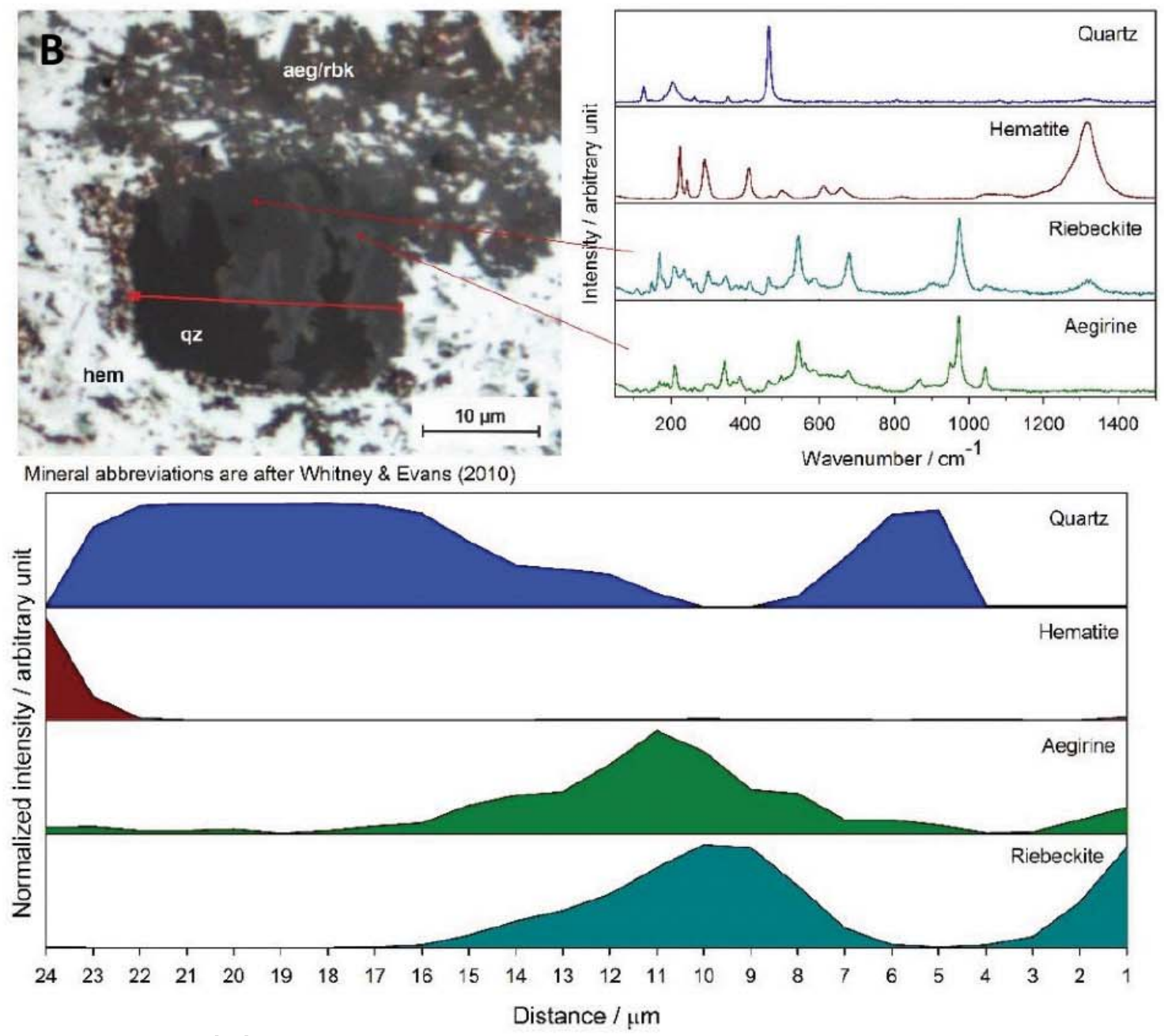

Figure 11. 

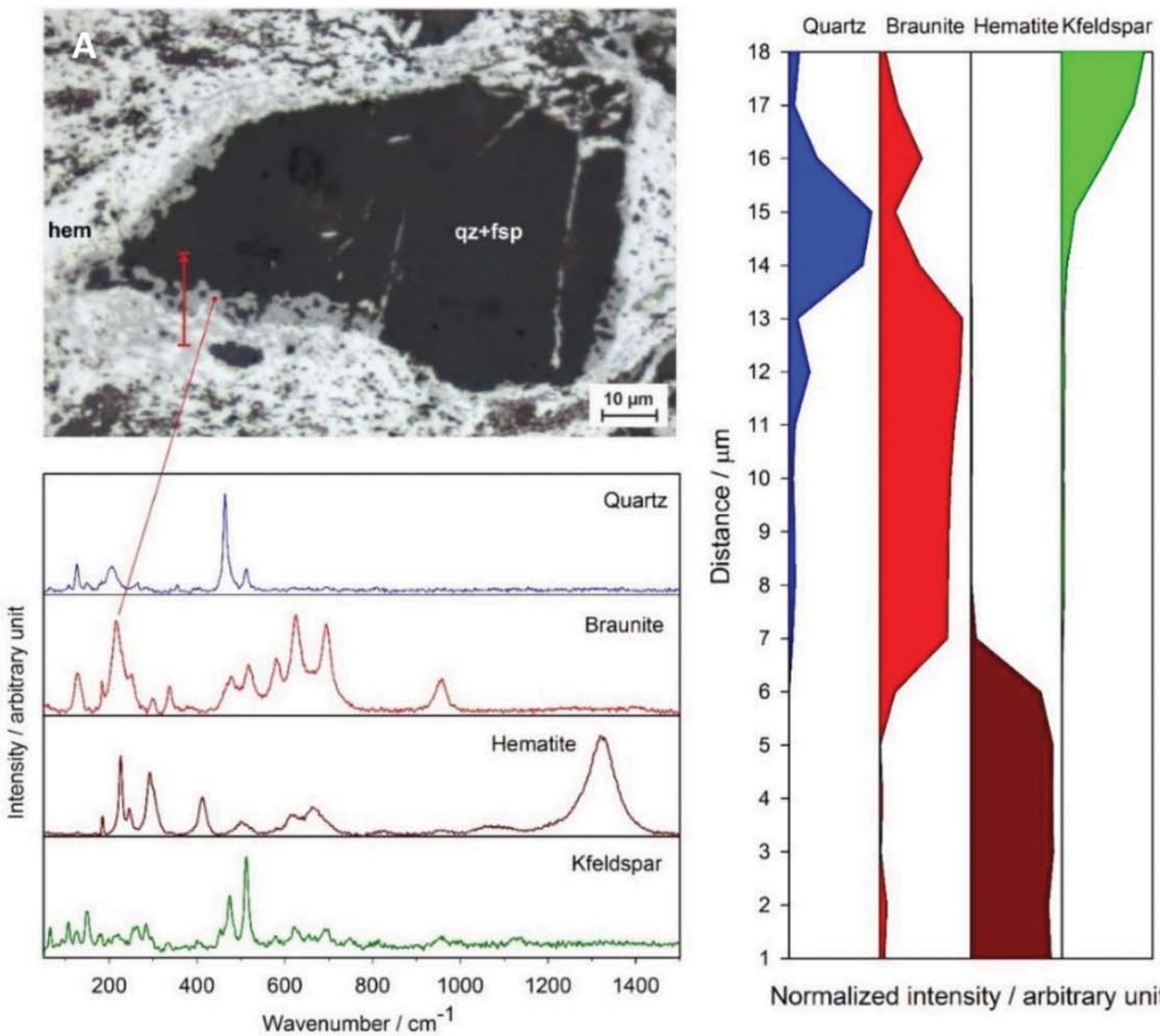

Normalized intensity / arbitrary unit

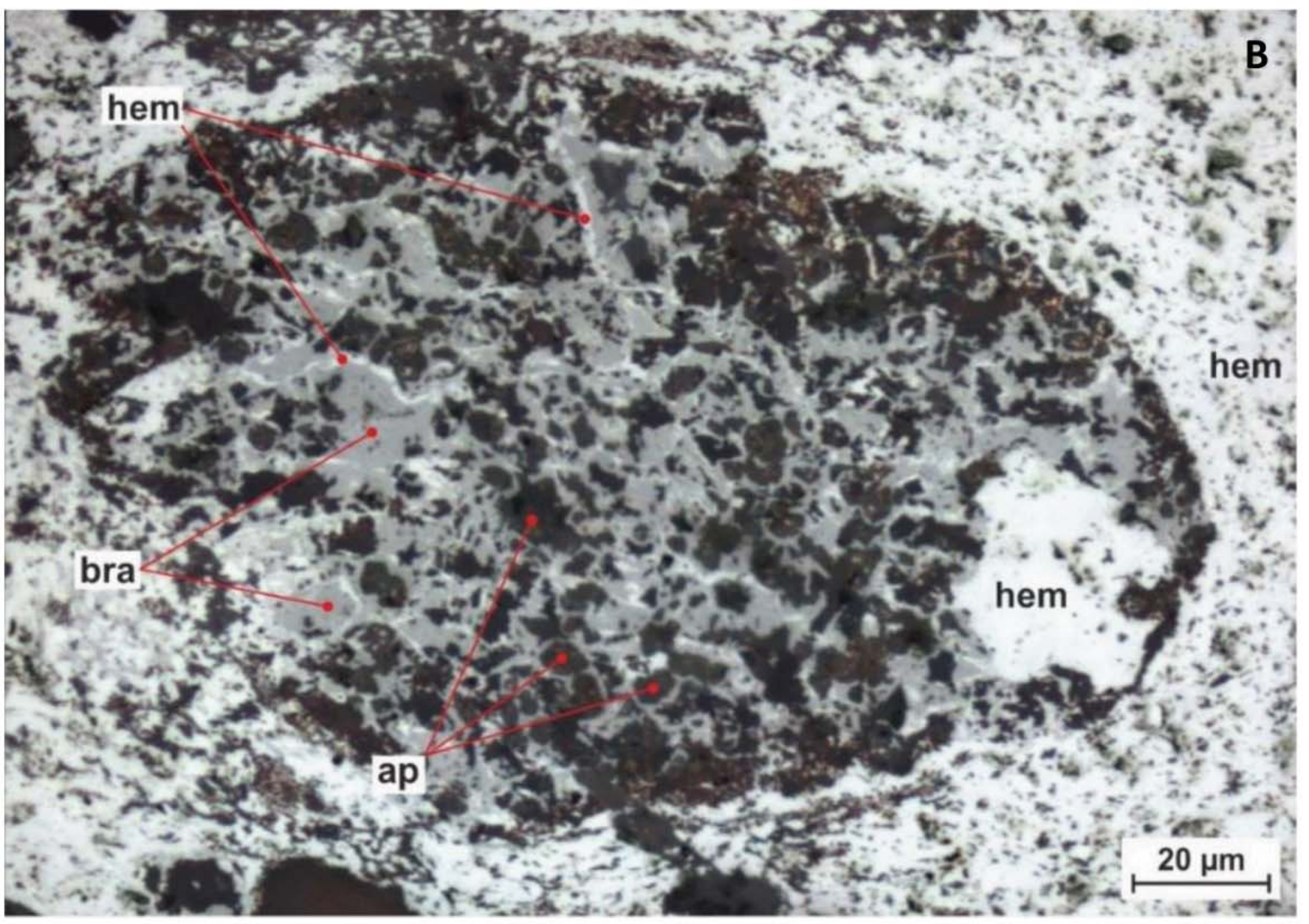

Figure 12. 

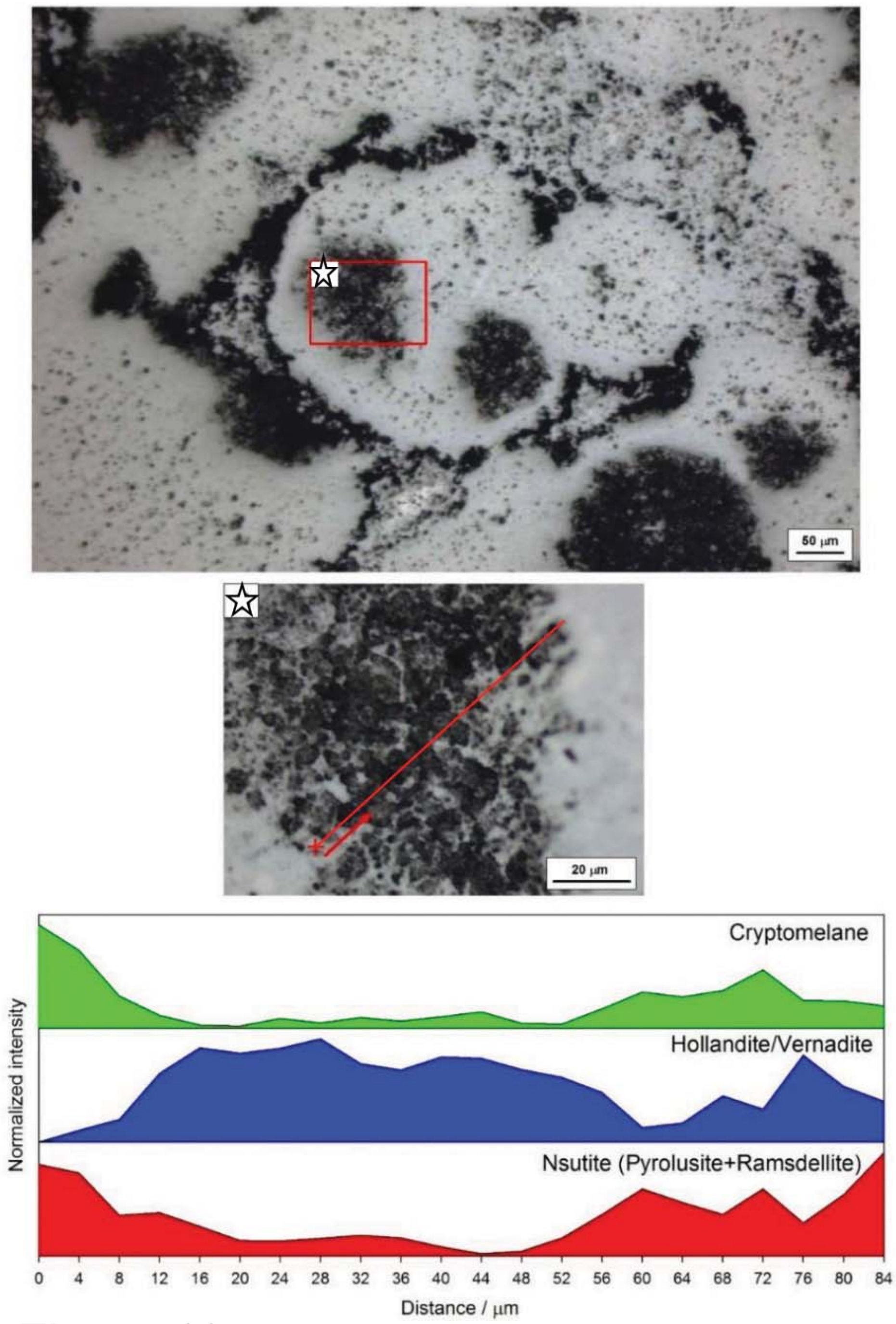

\section{Figure 13}




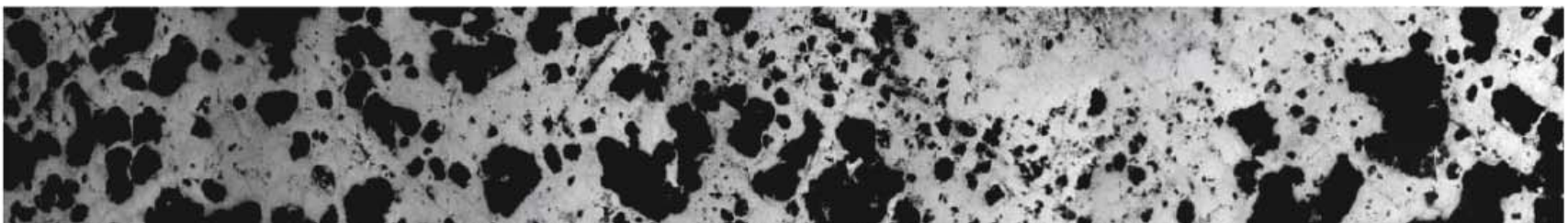

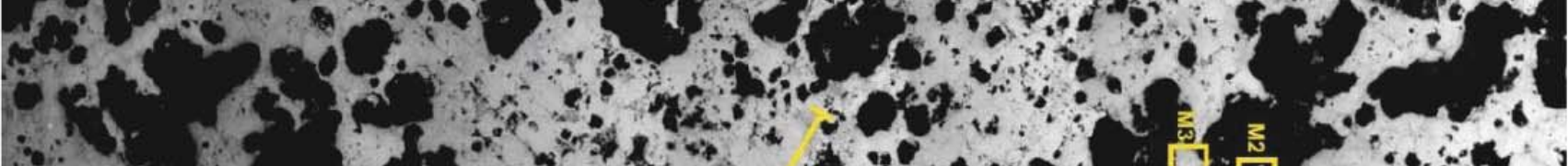

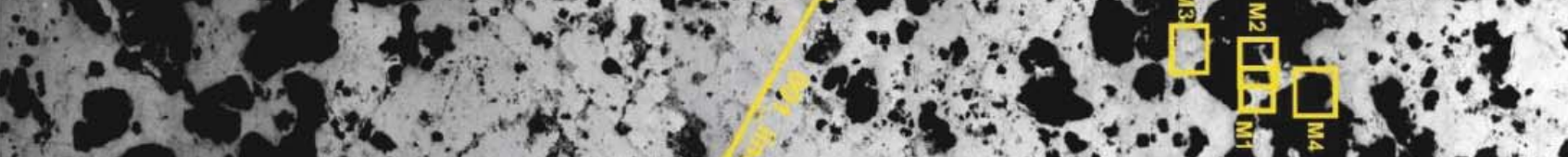

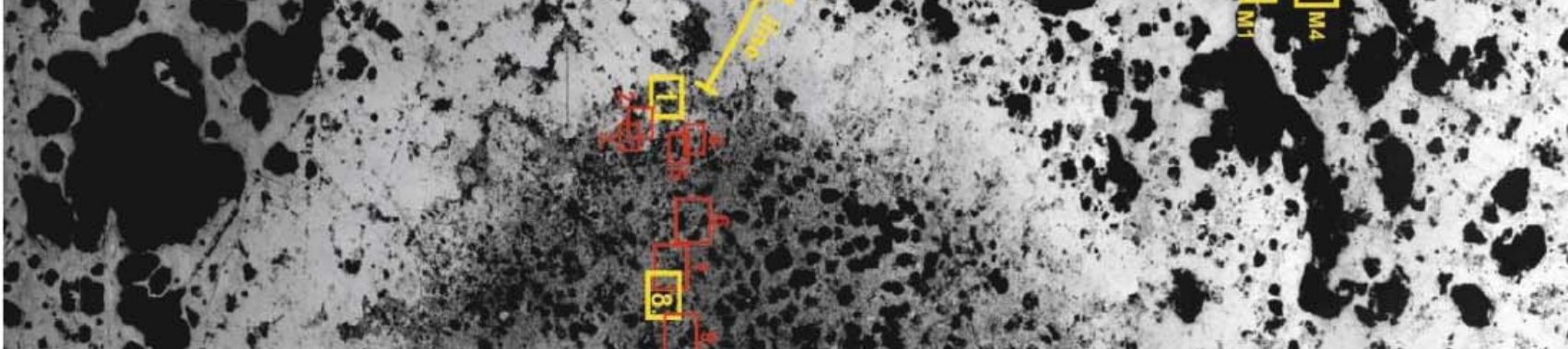

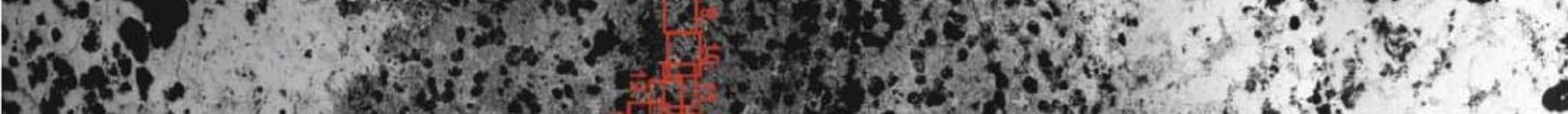

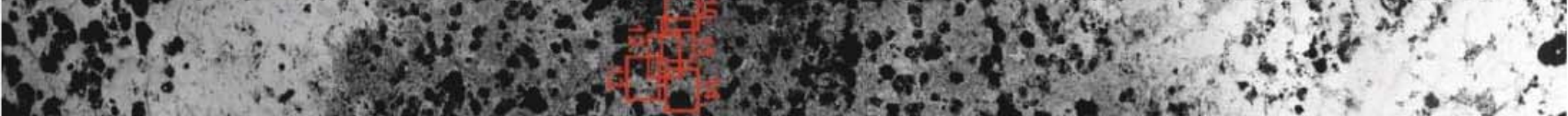

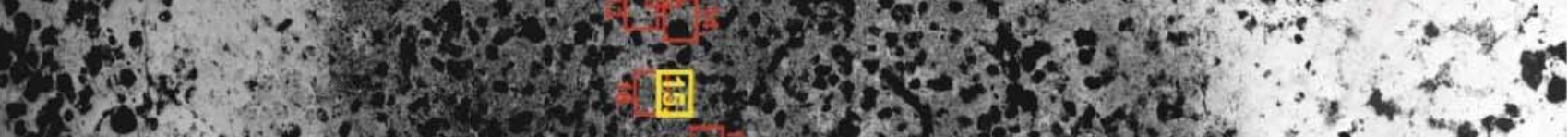

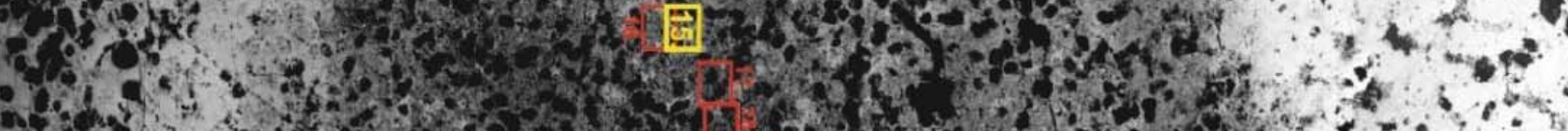
$33^{2}$

tôn

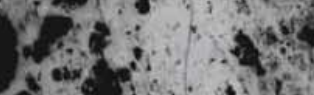

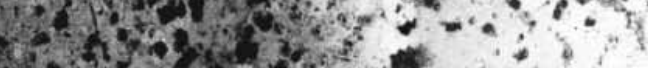
is

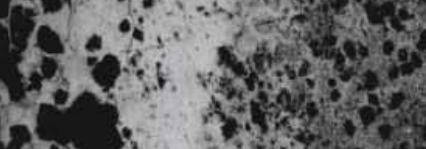

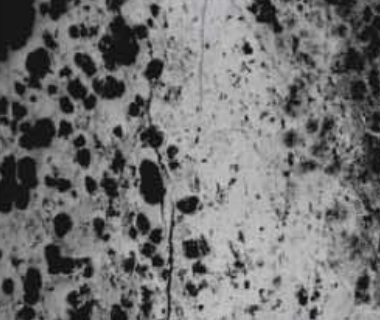

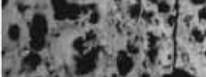

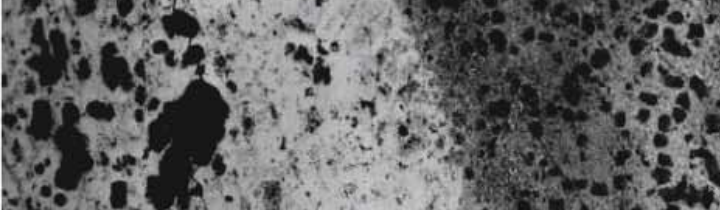

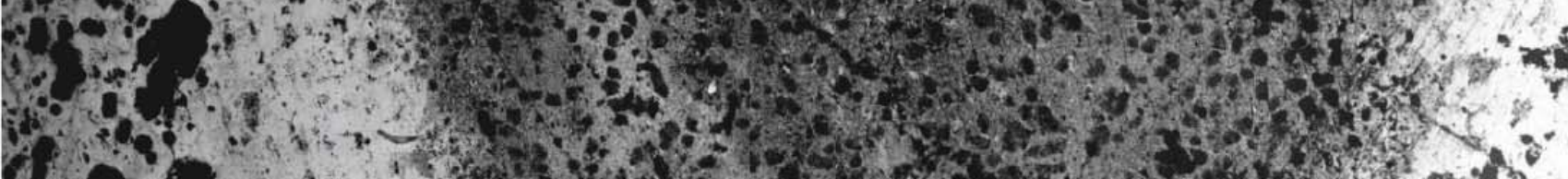

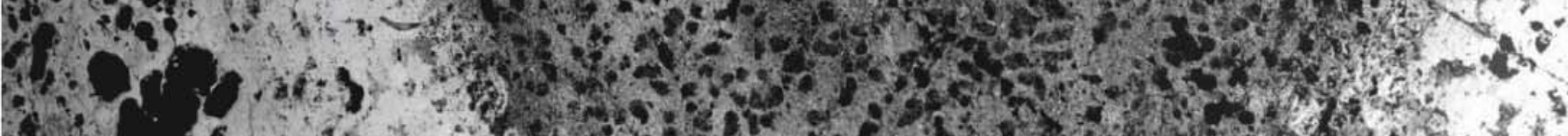

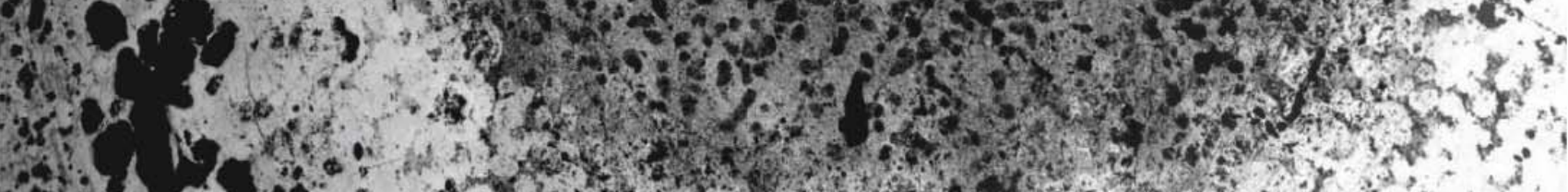

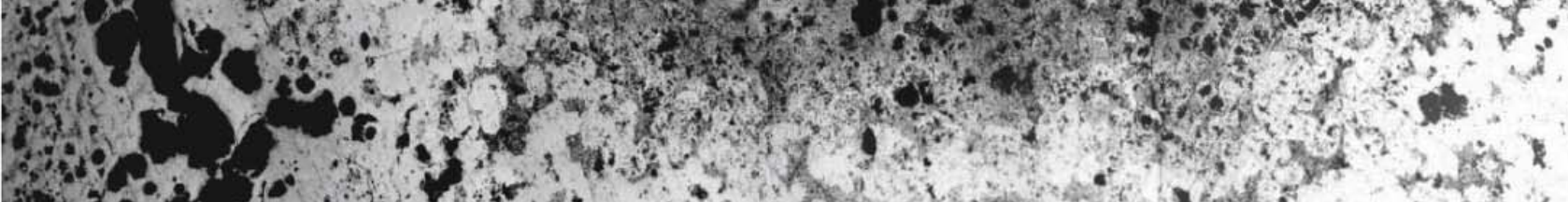

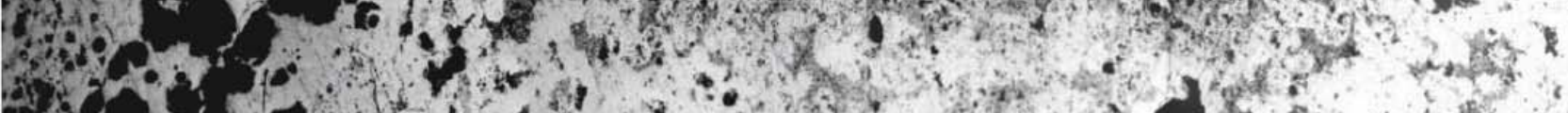

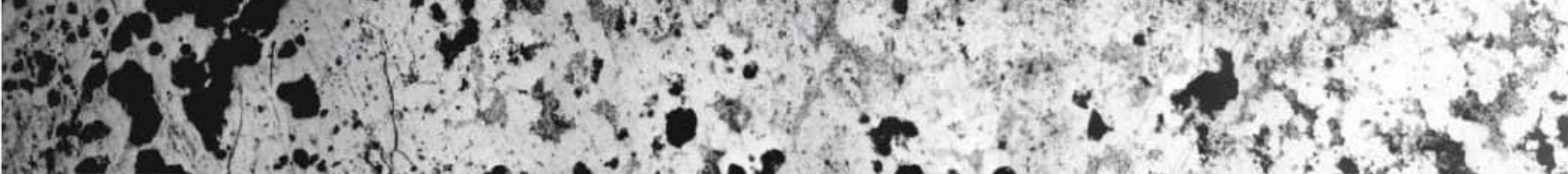

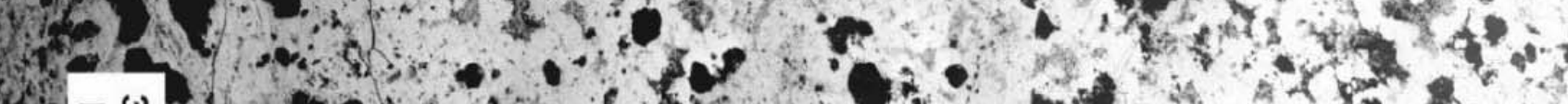

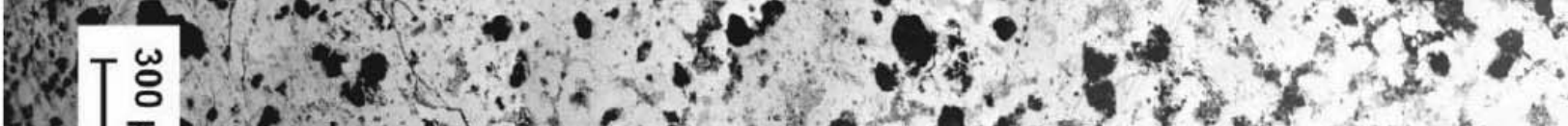
H.

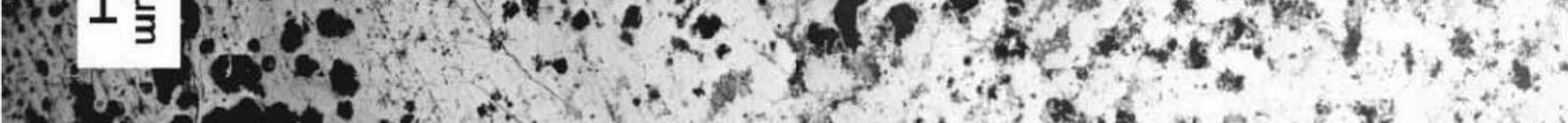

Figure 14. 


\section{Physico-chemical vs. bacterial Fe and Mn oxidation}

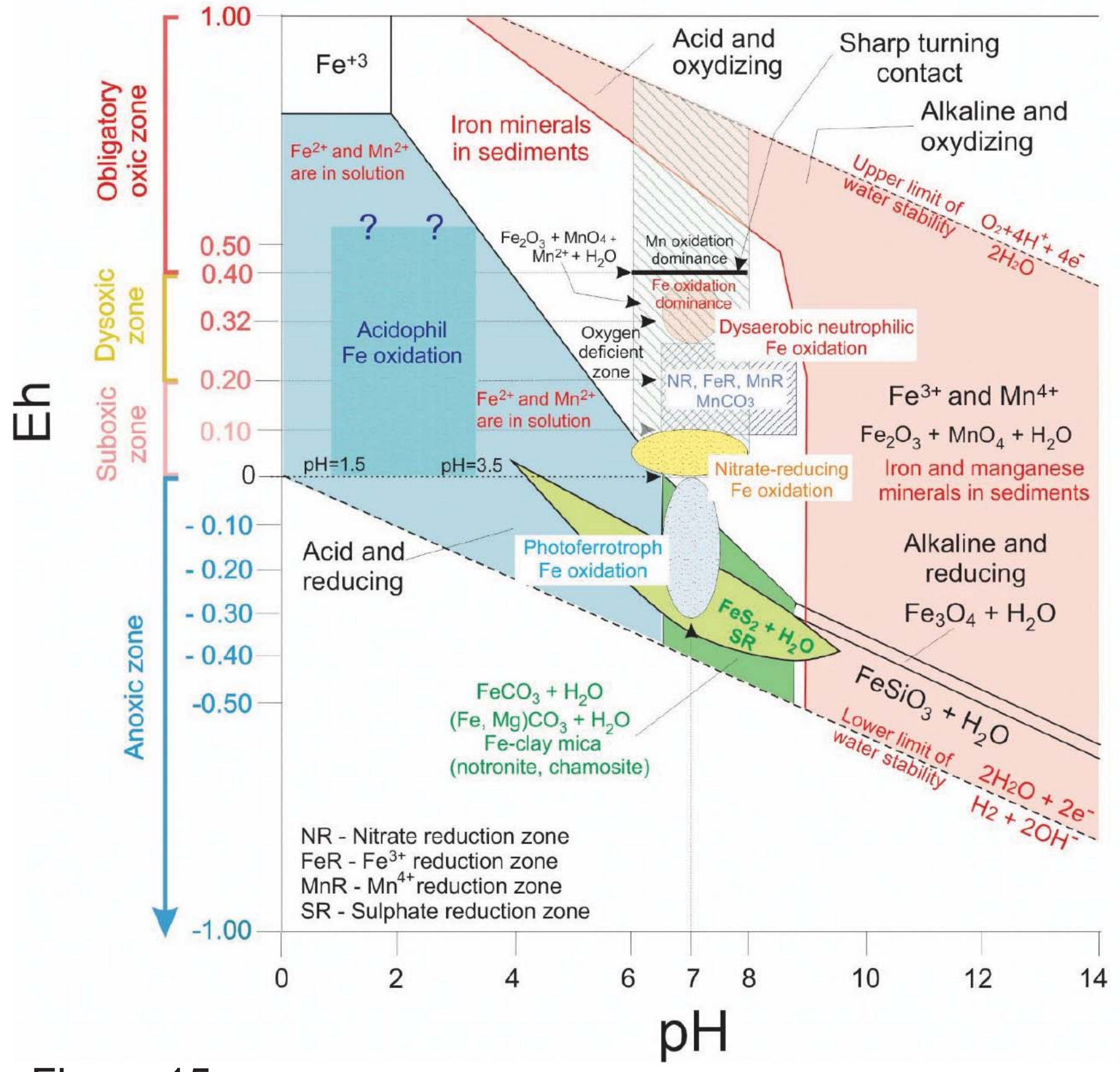

Figure 15. 


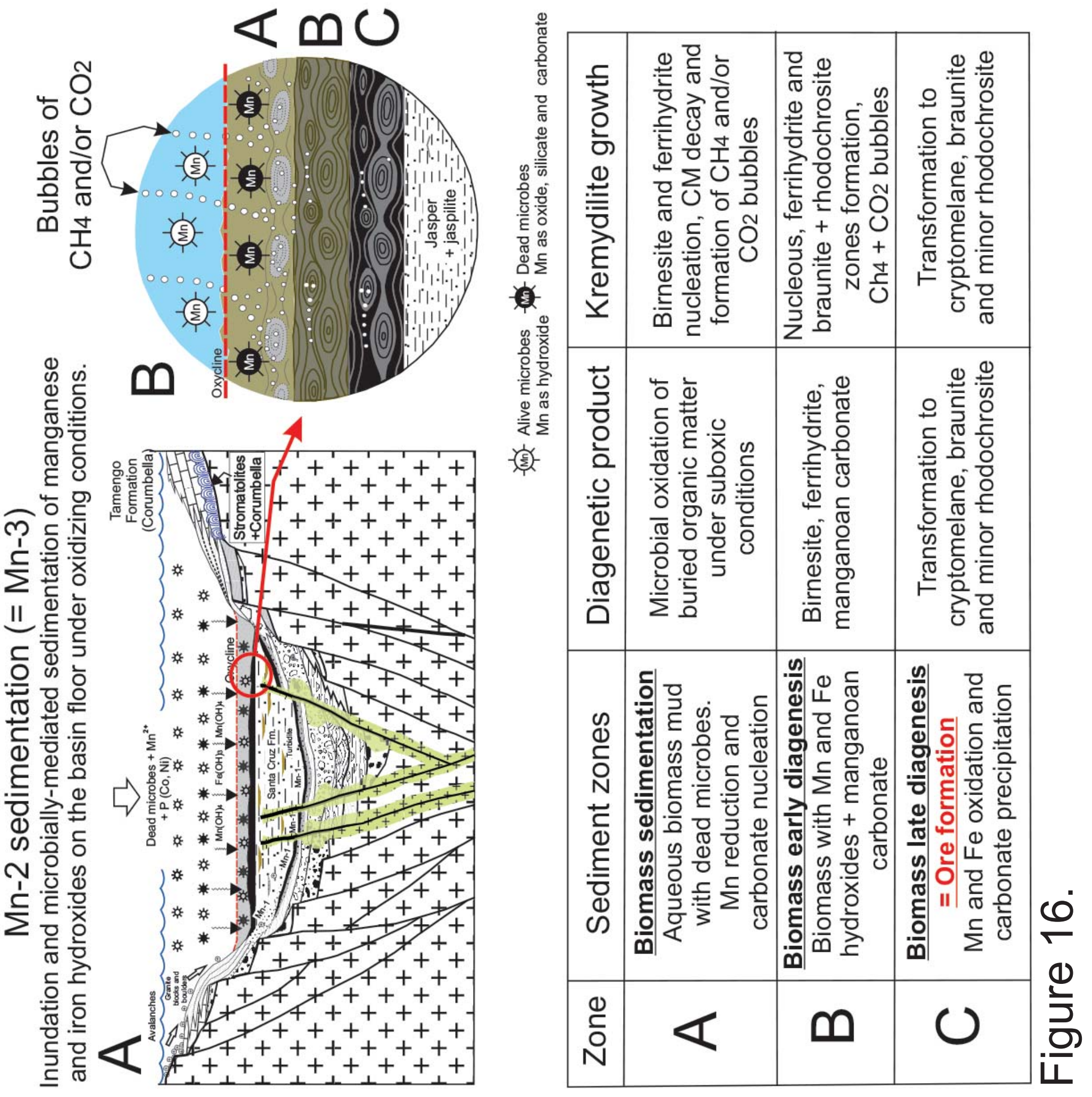




\section{Sedimentation and early diagenesis}

A

Microbialite

$\mathrm{II}=\mathrm{III}=\mathrm{III}=\mathrm{III}=\mathrm{III}=\mathrm{III}=\mathrm{III}$ $\equiv\|\| \equiv\|\| \equiv\|\| \equiv \equiv\|\| \equiv\|\| \equiv\|\| \equiv \equiv \|$ $\equiv\|\|\|\equiv\| \| \begin{gathered}\mathrm{CM}+\text { ferrihydrite }+ \\ \text { birnessite }+\end{gathered}$ 三 \|\|$\equiv \equiv\|\| \equiv$ Mn-Fe carbonate $\equiv\|\| \equiv\|\|$ $\equiv\|\| \equiv\|\| \equiv \equiv\|\| \equiv\|\| \equiv\|\| \equiv\|\| \equiv \equiv \|$ $=\mathrm{III}=\mathrm{III}=\mathrm{III}=\mathrm{III}=\mathrm{III}=\mathrm{III}=\mathrm{III}=$ Microbialite
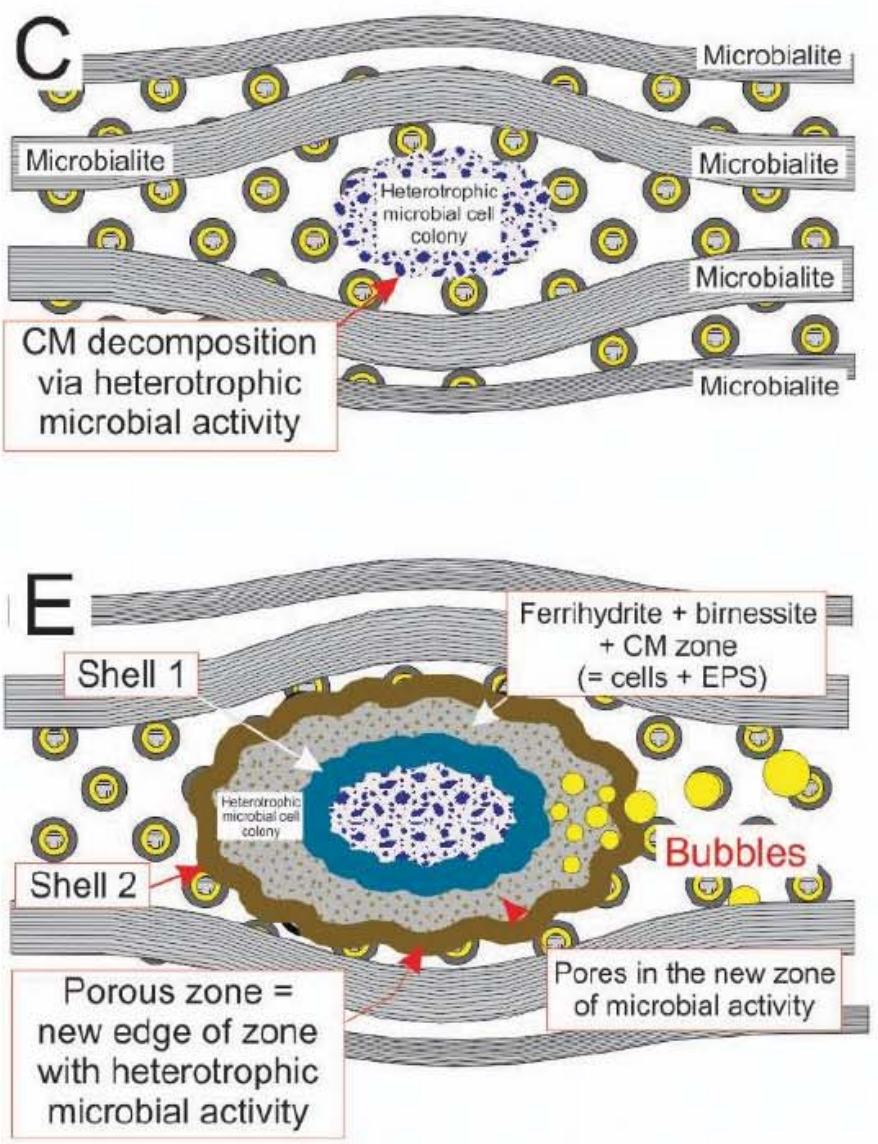

B

Microbial $M n$ reduction and $\mathrm{Mn}$ and $\mathrm{Fe}$ cab nucleation 三 $\mathrm{IIII}=\mathrm{IIII}=$ birnessite + En-Fe carbonate $=\mathrm{III}=\mathrm{III}=$

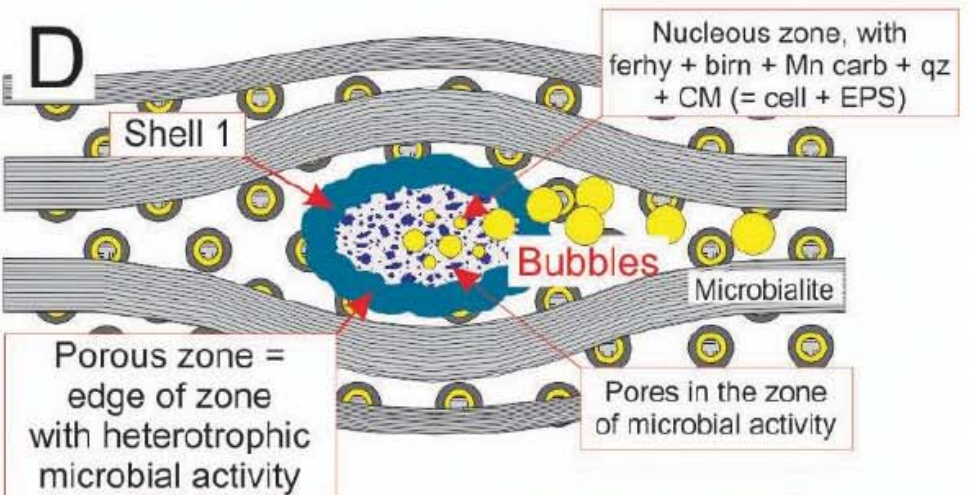
microbial activity

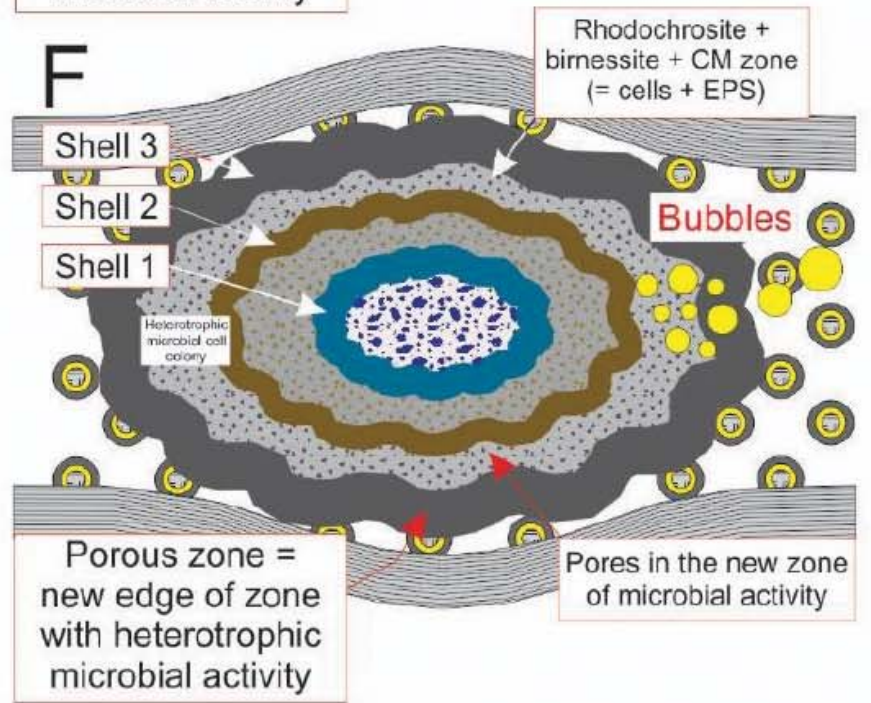

\section{Late and post-diagenesis}

\section{G cryptomelane + hollandite + braunite + hematite $+\mathrm{CM}$}

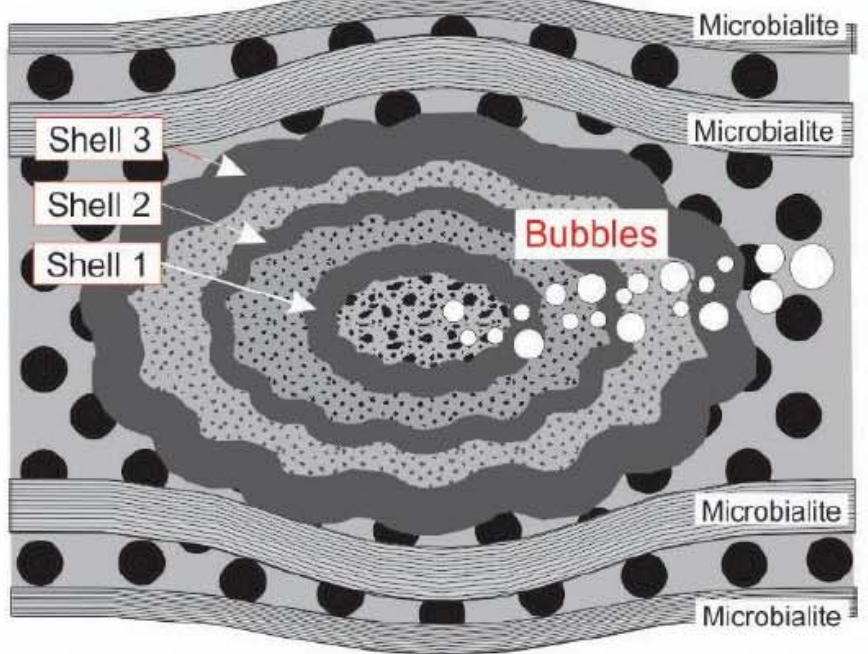

\section{Legend}

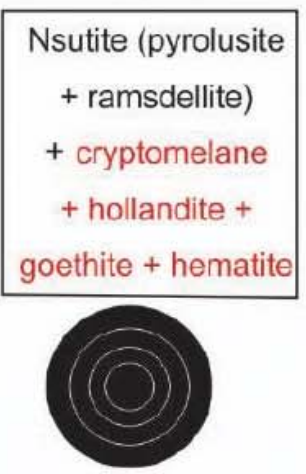


Table 1. Main features, mineralogical and selective element composition of ore beds (12 samples)(Biondi and Lopez 2017)

\begin{tabular}{|c|c|c|}
\hline Ore bed & Mn-1 & Mn-2-3 \\
\hline Main features & $\begin{array}{l}\text { Sandy (fragments of quartz, altered feldspar, } \\
\text { apatite, chert), laminated, amygdalite- } \\
\text { bearing }\end{array}$ & Kremydilite \\
\hline Mineralogy & $\begin{array}{l}\text { Figueirinha-Upper Mn-1 } \\
30-75 \text { v\% braunite } \\
<0.5 \text { vol\% aegirine } \\
3-15 \text { vol\% quartz } \\
5-15 \text { vol\% feldspar } \\
\text { 1-5 vol\% clay minerals, apatite, chlorite } \\
\text { locally } 10-30 \text { vol\%Fe-dolomite or siderite, } \\
\text { Mn-dolomite } \\
\text { São Domingos-Upper Mn-1 } \\
\text { (laminated, amygdalite-bearing) } \\
40-75 \text { vol\% cryptomelane-hollandite } \\
\text { 10-30 vol\% quartz } \\
\text { 10-15 vol\% hematite, apatite, clay minerals } \\
\text { Composition of amygdalite cores } \\
60-90 \text { vol\% cryptomelane (hollandite?) } \\
\text { 0-10 vol\% quartz } \\
5-15 \text { vol\% hematite, clay minerals } \\
\text { Santa Cruz-Mn-1 } \\
\text { arkozic sandstone cemented by hollandite } \\
\text { (cryptomelane, pyrolusite), quartz, feldspar, } \\
\text { hematite } \\
\text { Composition offerruginous sandstone } \\
30-40 \text { vol\% hematite } \\
60-70 \text { vol\% quartz } \\
1-5 \text { vol\% clay minerals }\end{array}$ & $\begin{array}{l}\text { 77-98 vol\% cryptomelane } \\
0-23 \text { vol\% hollandite } \\
9-19 \text { vol\% braunite } \\
7-21 \text { vol\% hematite } \\
0-5 \text { vol\% clay minerals and CM }\end{array}$ \\
\hline \multicolumn{3}{|c|}{ Average chemical composition of selective elements (wt. \%) } \\
\hline $\begin{array}{l}\text { Mn } \\
\text { Fe } \\
\text { K } \\
\text { Ba } \\
\text { LOI }\end{array}$ & $\begin{array}{l}\text { Mn-1 contains a Lower and an Upper part, } \\
\text { whose compositions vary locally, which is } \\
\text { the reason why it is not possible to } \\
\text { determine the average chemical } \\
\text { composition of this unit. }\end{array}$ & $\begin{array}{l}50.06(\mathrm{SD}-2.73 \%) \\
8.58(\mathrm{SD}-2.59 \%) \\
1.82(\mathrm{SD}-0.75 \%) \\
0.29(\mathrm{SD}-0.30 \%) \\
10.80(\mathrm{SD}-0.88 \%)\end{array}$ \\
\hline
\end{tabular}


Table 2. Samples and used methods

\begin{tabular}{|c|c|c|c|c|c|c|c|c|}
\hline Sample ID & Layer & Locality (Fig. 1) & TS* & OM & CL & FTIR & Raman & XRD \\
\hline COR-81 & Mn-3 & $\begin{array}{l}\text { MCR-VALE mine, Sta } \\
\text { Cruz Plateau }\end{array}$ & $\mathbf{x}$ & $\mathbf{x}(\mathbf{3 4})$ & & & $\mathbf{x}(\mathbf{1 , 9 0 3 )}$ & \\
\hline COR-78-F3 & Mn-2 & $\begin{array}{l}\text { Urucum-VALE mine, } \\
\text { Urucum W plateau }\end{array}$ & $\mathbf{x}$ & $x(65)$ & & $\mathbf{x}(60)$ & & \\
\hline COR-78-D1 & Mn-2 & $\begin{array}{l}\text { Urucum-VALE mine, } \\
\text { Urucum W plateau }\end{array}$ & $\mathbf{x}$ & $\mathbf{x}(\mathbf{5 9})$ & $\mathbf{x}(\mathbf{1 1})$ & & $x(3,456)$ & \\
\hline COR-75-B5 & Mn-2 & $\begin{array}{l}\text { Urucum-VALE mine, } \\
\text { Urucum W plateau }\end{array}$ & $\mathbf{x}$ & $\mathbf{x}(63)$ & $\mathbf{x}(\mathbf{6})$ & & $x(2,449)$ & \\
\hline COR-75-2 & Mn-2 & $\begin{array}{l}\text { Urucum-VALE mine, } \\
\text { Urucum W plateau }\end{array}$ & $\mathbf{x}$ & $\mathbf{x}(56)$ & $\mathbf{x}(\mathbf{9})$ & & $\mathbf{x}(1,209)$ & \\
\hline COR-48B & Mn-2 & & $\mathbf{x}$ & & & $x(178)$ & & \\
\hline COR-36-A1-A2 & Mn-2 & $\begin{array}{l}\text { MMX mine, Urucum E } \\
\text { plateau }\end{array}$ & $\mathbf{x}$ & $\mathbf{x}(56)$ & & $\mathbf{x}(50)$ & & \\
\hline COR-10 & Mn-1 & $\begin{array}{l}\text { Figueirinha mine, Sta } \\
\text { Cruz N plateau }\end{array}$ & $\mathbf{x}$ & $\mathbf{x}(\mathbf{9 5})$ & $\mathbf{x}(\mathbf{2 3})$ & $\mathbf{x}(\mathbf{1 4})$ & $x(504)$ & $\mathbf{x}$ \\
\hline COR-7 & Mn-1 & $\begin{array}{l}\text { Figueirinha mine, Sta } \\
\text { Cruz N plateau }\end{array}$ & $\mathbf{x}$ & $\mathbf{x}(\mathbf{3 8})$ & $\mathbf{x}(27)$ & $\mathbf{x}(\mathbf{1 2})$ & $x(504)$ & $\mathbf{x}$ \\
\hline COR-6 & Mn-1 & $\begin{array}{l}\text { Figueirinha mine, Sta } \\
\text { Cruz N plateau }\end{array}$ & $\mathbf{x}$ & $x(46)$ & & $\mathbf{x}(37)$ & & \\
\hline COR-4B & Mn-1 & $\begin{array}{l}\text { Figueirinha mine, Sta } \\
\text { Cruz N plateau }\end{array}$ & $\mathbf{x}$ & $x(43)$ & $\mathbf{x}(\mathbf{1 0})$ & & $x(400)$ & \\
\hline COR-32 & Mn-1 & $\begin{array}{l}\text { Sao Domingos mine, Sta } \\
\text { Cruz SW plateau }\end{array}$ & $\mathbf{x}$ & $x(79)$ & & $\mathbf{x}(32)$ & & \\
\hline COR-31 & Mn-1 & $\begin{array}{l}\text { Sao Domingos mine, Sta } \\
\text { Cruz SW plateau }\end{array}$ & $\mathbf{x}$ & $\mathbf{x}(\mathbf{5 6})$ & $\mathbf{x}(27)$ & $\mathbf{x}(32)$ & $x(504)$ & $\mathbf{x}$ \\
\hline $\begin{array}{l}\text { Total } 14 \text { samples } \\
\text { (photos, spectra) }\end{array}$ & & & & 690 & 113 & 415 & 10,997 & 3 \\
\hline
\end{tabular}

Abbrev.: TS-thin section; OM-optical rock microscopy; CL-cathodoluminescence microscopy; FTIR-ATR-infra red spectroscopy; Raman-Raman spectroscopy; XRD-X-ray powder diffraction gray background: samples from Mn-2 and 3 beds (Fig. 3-4 and SI 3-Fig) number of analyses in brackets. 
Table 3. Mineral composition

\begin{tabular}{|c|c|c|c|c|c|c|c|}
\hline $\begin{array}{l}\text { Samples } \rightarrow \\
\text { Minerals } \downarrow\end{array}$ & COR-6 & COR-7 & COR-10 & COR-31 & COR-32 & COR-36A1 & COR-78F3 \\
\hline $\begin{array}{l}\text { Mn minerals } \\
\text { todorokite } \\
\text { ramsdellite } \\
\text { cryptomelane } \\
\text { pyrolusite } \\
\text { romanéchite } \\
\text { serandite } \\
\text { braunite } \\
\end{array}$ & $\begin{array}{l}* \\
* \\
*\end{array}$ & & $*$ & & $\begin{array}{l}* \\
*\end{array}$ & $\begin{array}{l}* \\
*\end{array}$ & $*$ \\
\hline $\begin{array}{l}\text { Fe minerals } \\
\text { ferrihydrite } \\
\text { lepidocrocite } \\
\text { hematite } \\
\text { aegirine } \\
\text { pyrite }\end{array}$ & $*$ & $*$ & & $\begin{array}{l}* \\
* \\
* \\
\end{array}$ & $\begin{array}{l}* \\
*\end{array}$ & $*$ & $\begin{array}{l}* \\
*\end{array}$ \\
\hline $\begin{array}{l}\text { Other minerals } \\
\text { apatite } \\
\text { feldspar (albite, } \\
\text { anortite) } \\
\text { chlorite } \\
\text { quartz } \\
\text { kaolinite/dickite } \\
\text { celadonite }\end{array}$ & $*$ & $\begin{array}{l}* \\
*\end{array}$ & $\begin{array}{l}* \\
*\end{array}$ & $\begin{array}{l}\text { * } \\
* \\
* \\
*\end{array}$ & $\begin{array}{l}* \\
* \\
*\end{array}$ & & \\
\hline Organic matter & $*$ & $*$ & $*$ & $*$ & $*$ & $*$ & $*$ \\
\hline
\end{tabular}




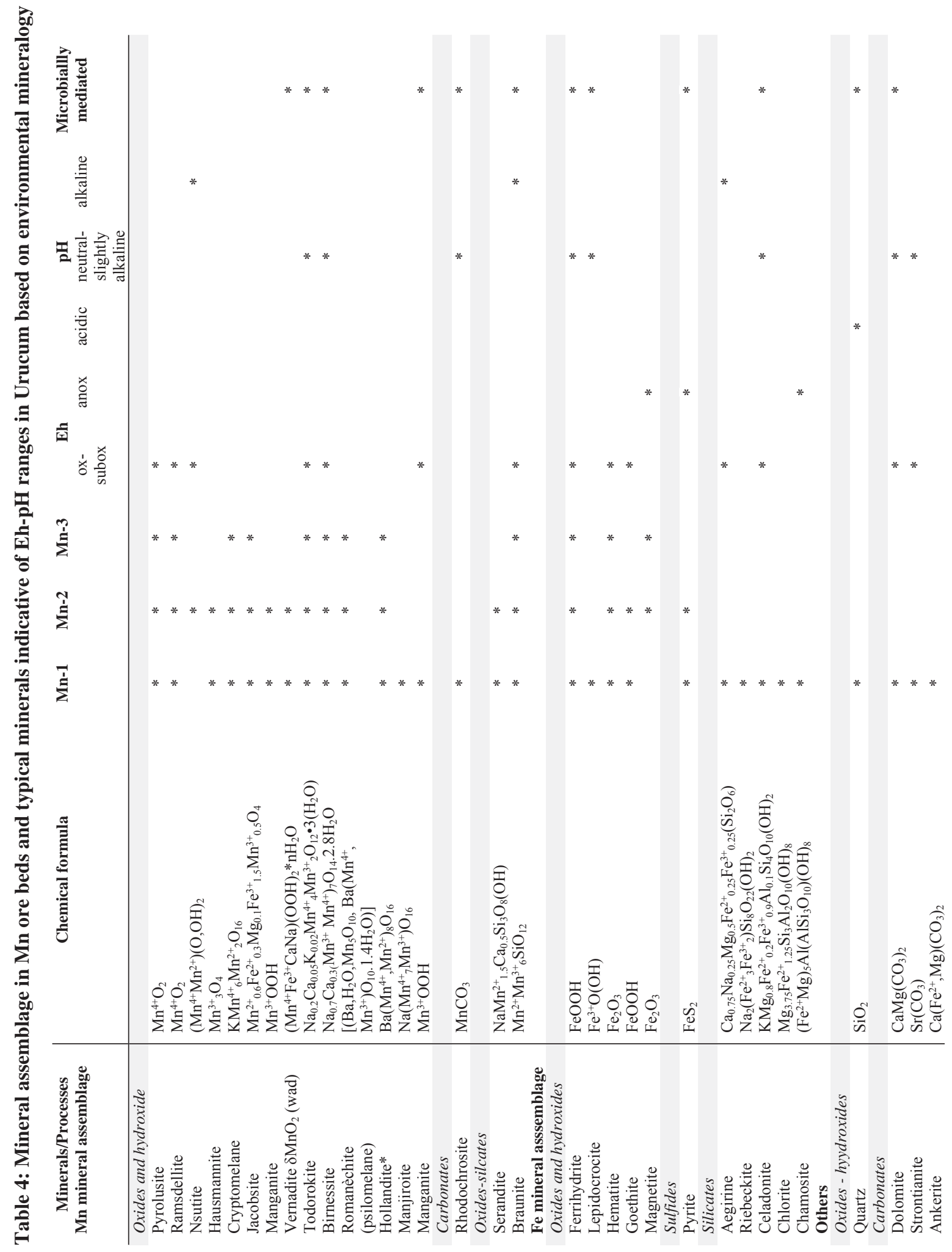




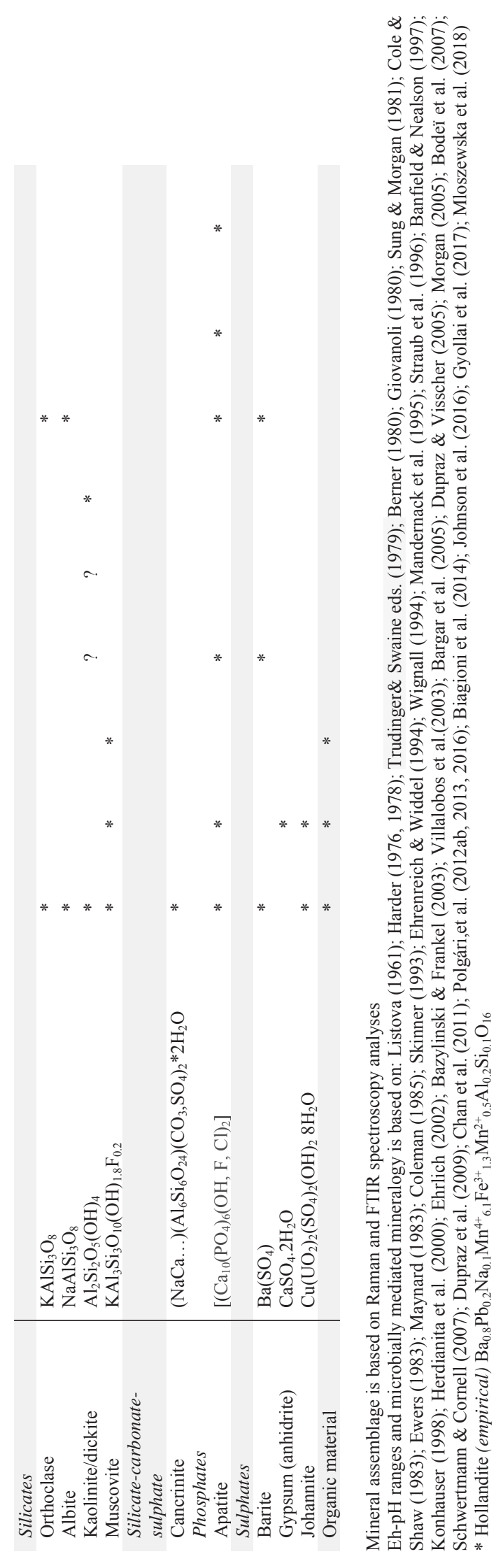


Table 5. Environmental oxygen levels

\begin{tabular}{l|cccc}
$\begin{array}{c}\text { Environmental } \\
\text { oxygen levels }\end{array}$ & Eh $(\mathbf{V})$ & $\begin{array}{c}\text { Dissolved } \\
\text { oxygen }(\mathbf{D O})\end{array}$ & $\begin{array}{c}\text { FeOB } \\
\text { demand* }\end{array}$ & $\begin{array}{c}\text { MnOB } \\
\text { demand }\end{array}$ \\
\hline $\begin{array}{l}\text { obligatory oxic } \\
\text { dysoxic }\end{array}$ & $0.4<\mathrm{Eh}<1.0$ & $\mathrm{DO}>2 \mathrm{~mL} / \mathrm{L}$ & $\mathrm{x}$ \\
& $0.2-0.4$ & $\mathrm{DO} 0.2-2.0$ \\
$\mathrm{~mL} / \mathrm{L}$ & $\approx 0.3$ & \\
$\begin{array}{l}\text { suboxic } \\
\text { anoxic }\end{array}$ & $0-0.2$ & $\mathrm{DO} 0-0.2 \mathrm{~mL} / \mathrm{L}$ & \\
& $<0$ & &
\end{tabular}

*: FeOB demand is around the dysoxic-suboxic zone, and suboxic is the generally used as simplified form; abbrev: FeOB-Fe oxidizing bacteria; MnOB-Mn oxidizing bacteria (Berner 1980; Coleman 1985; Wignall 1994) 


\section{Conflict of interest}

The authors declare no competing financial interests on this research. The research in this manuscript has not been previously published nor is under consideration elsewhere. All authors have approved submission of this manuscript to Precambrian Research. 


\section{SUPPORTING INFORMATION}

\section{BIOGENESIS OF THE NEOPROTEROZOIC KREMYDILITE MANGANESE ORES FROM URUCUM (BRAZIL) - A NEW MANGANESE ORE TYPE}

\section{Running title: Biogenesis of a Neoproterozoic manganese ore}

Joăo Carlos Biondi ${ }^{1+}$, Márta Polgári ${ }^{2,3^{*+}}$, Ildikó Gyollai ${ }^{2}$, Krisztián Fintor ${ }^{4}$, Ivett Kovács ${ }^{2}$, József Fekete ${ }^{2}$, Stephen Mojzsis ${ }^{2,5}$

${ }^{1}$ Federal University of Paraná State, Polytechnic Center, Geology Department, 81531-980 Curitiba,Brazil,e-mail: biondiufpr@gmail.com

${ }^{2}$ Institute for Geological and Geochemical Research, RCAES, Hungarian Academy of Sciences, 1112 Budapest, Budaörsi u. 45, Hungary, e-mail: rodokrozit@gmail.com. gyildi@gmail.com,iv.kovacs@gmail.com,fekete.jozsef@csfk.mta.hu

${ }^{3}$ Eszterházy Károly University, Dept. of Natural Geography and Geoinformatics, 3300 Eger, Leányka u. 6, Hungary

${ }^{4}$ Szeged University, Dept. of Mineralogy, Geochemistry and Petrology, 6722 Szeged, Egyetem u. 2-6, Hungary,e-mail:efkrisz@gmail.com

${ }^{5}$ University of Colorado, Department of Geological Sciences, 2200 Colorado Avenue, UCB 399, Boulder, Colorado 80309-0399, United States of America

*corresponding author:

rodokrozit@gmail.com

${ }^{+}$The first two authors have contributed equally to this work

\section{Content}

SI 1-Fig. Map and geological section of Urucum

SI 2-Fig. Stratigraphic columns of the Jacadigo Group

SI 3-Fig. Representative samples of Mn-1, Mn-2 and Mn-3

SI 4-Fig. Pores and micro-channels in kremydilites

SI 5-Fig. Structure of kremydilite

SI 6-Fig. Panorama images of the analyzed samples

SI 7-Fig. Biomat structures of representative samples

SI 8-Fig. Microtexture of samples by optical rock microscopy

SI 9-Fig. CL images of samples

SI 10-Table. FTIR measurement of samples 
SI 11-Fig. Interpretation of mineral composition and distribution of spherical (bubble-like) structure of sample 36-A based on FTIR

SI 12-Fig. Mineral distribution in profiles by Raman spectroscopy

SI 13-Fig. Mineralogical distribution by Raman spectroscopy (sample 75-2)

SI 14-Fig. Mineral phases and distribution in spherical (bubble-like) structures by Raman spectroscopy

SI 15-Table. Summary of formation of Mn ore beds according to structural hierarchy 
SI 1-Fig. Map and geological section of Urucum
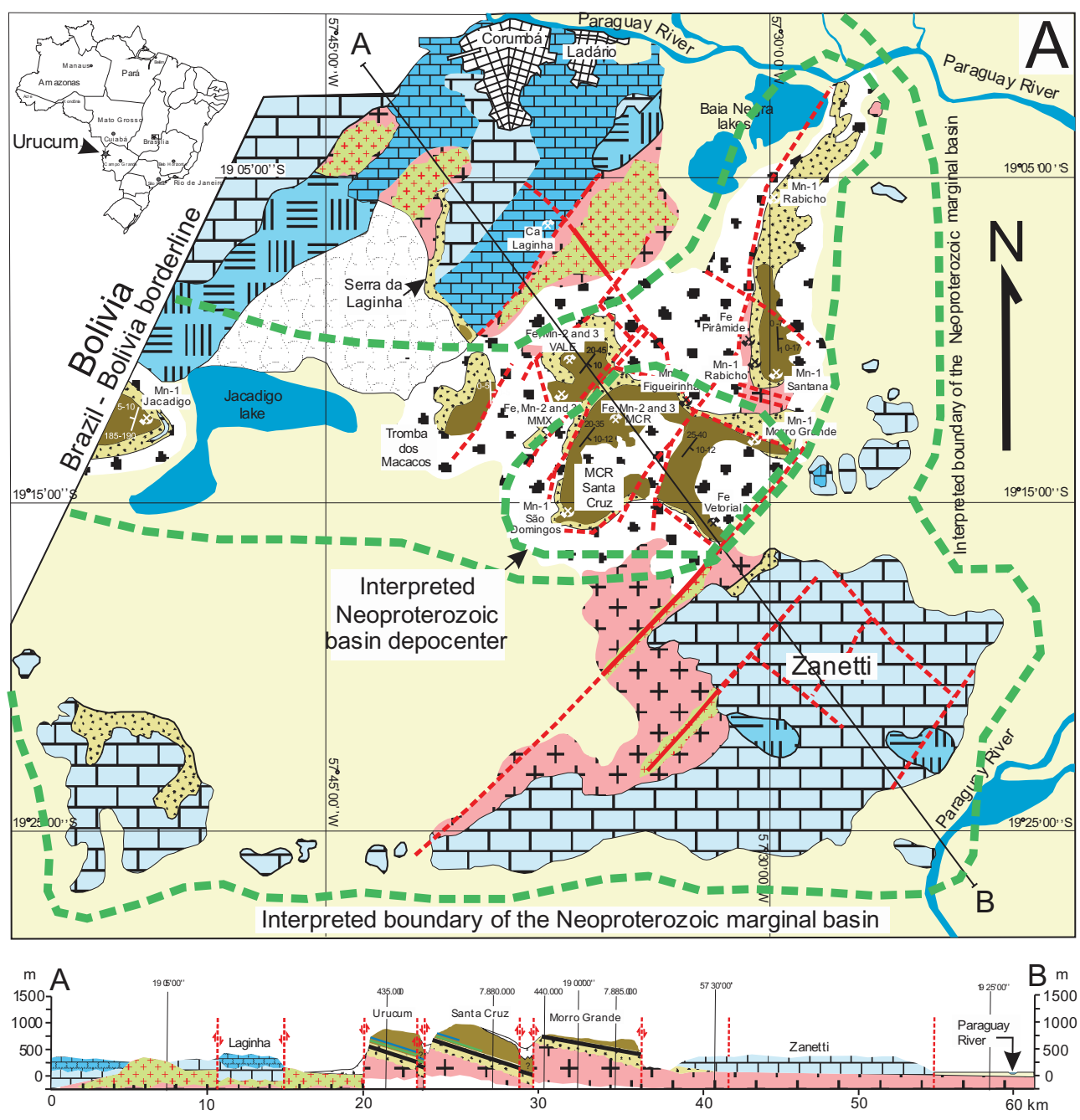

\begin{tabular}{|c|c|c|c|c|}
\hline \multicolumn{3}{|r|}{ Lithostratigraphy } & \multirow{2}{*}{\multicolumn{2}{|c|}{$\begin{array}{lll}0 & 5 & 10 \mathrm{~km} \\
\end{array}$}} \\
\hline & Pleistocene & Neoproterozoic & & \\
\hline \multirow[b]{2}{*}{ 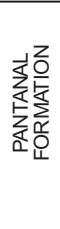 } & & JACADIGO GROUP & \multicolumn{2}{|c|}{ Legend } \\
\hline & \begin{tabular}{|l} 
Sand and clays \\
Alluvial terrace \\
Sand and clays \\
Colluvium \\
Sand and BIF \\
boulders
\end{tabular} & $\begin{array}{l}\text { SANTA CRUZ FORMATION } \\
\text { Banded iron formations (BIF), } \\
\text { grain ironstones, ferruginous } \\
\text { sandstones, siltstones, arkoses } \\
\text { and conglomerates, locally } \\
\text { with presence of Corumbella. } \\
\begin{array}{l}\text { Presence of massive } \\
\text { manganese layers Mn-1, } 2 \text { and 3. Mn }\end{array}\end{array}$ & $\begin{array}{l}\mathrm{X} \\
\mathrm{Fe}\end{array}$ & $\begin{array}{l}\text { Active mining } \\
\text { Closed mine } \\
\text { Ore element } \\
\text { Manganese }\end{array}$ \\
\hline \multirow{4}{*}{ 蓆亭 } & \multirow{4}{*}{ 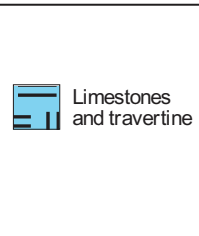 } & $\begin{array}{l}\text { URUCUM FORMATION } \\
\begin{array}{l}\text { Sandstones, conglomerates and } \\
\text { siltstones, locally with manganese } \\
\text { cement and stromatolitefragments. }\end{array}\end{array}$ & & $\begin{array}{l}\text { Confirmed and } \\
\text { interpreted fault }\end{array}$ \\
\hline & & Paleoproterozoic & \multirow{3}{*}{\multicolumn{2}{|c|}{$\begin{array}{ll}K_{10}^{20-45} & \text { Strike } \\
\text { Dip }\end{array}$}} \\
\hline & & RIO APA COMPLEX & & \\
\hline & & {$\left[\begin{array}{l}+ \\
+\end{array}\right.$} & & \\
\hline
\end{tabular}

SI 1-Fig. (A) Geological map (modified after Urban et al. 1992) and geological cross-section. Lines with an interpretation of the probable relative depth of the depocenter of the Urucum marginal basin, and the regional distribution of hydrothermalized granites were added to the map. (B) Lithostratigraphy of the Urucum mining region (modified after Biondi and Lopez 2017). 
Location in the Urucum basin

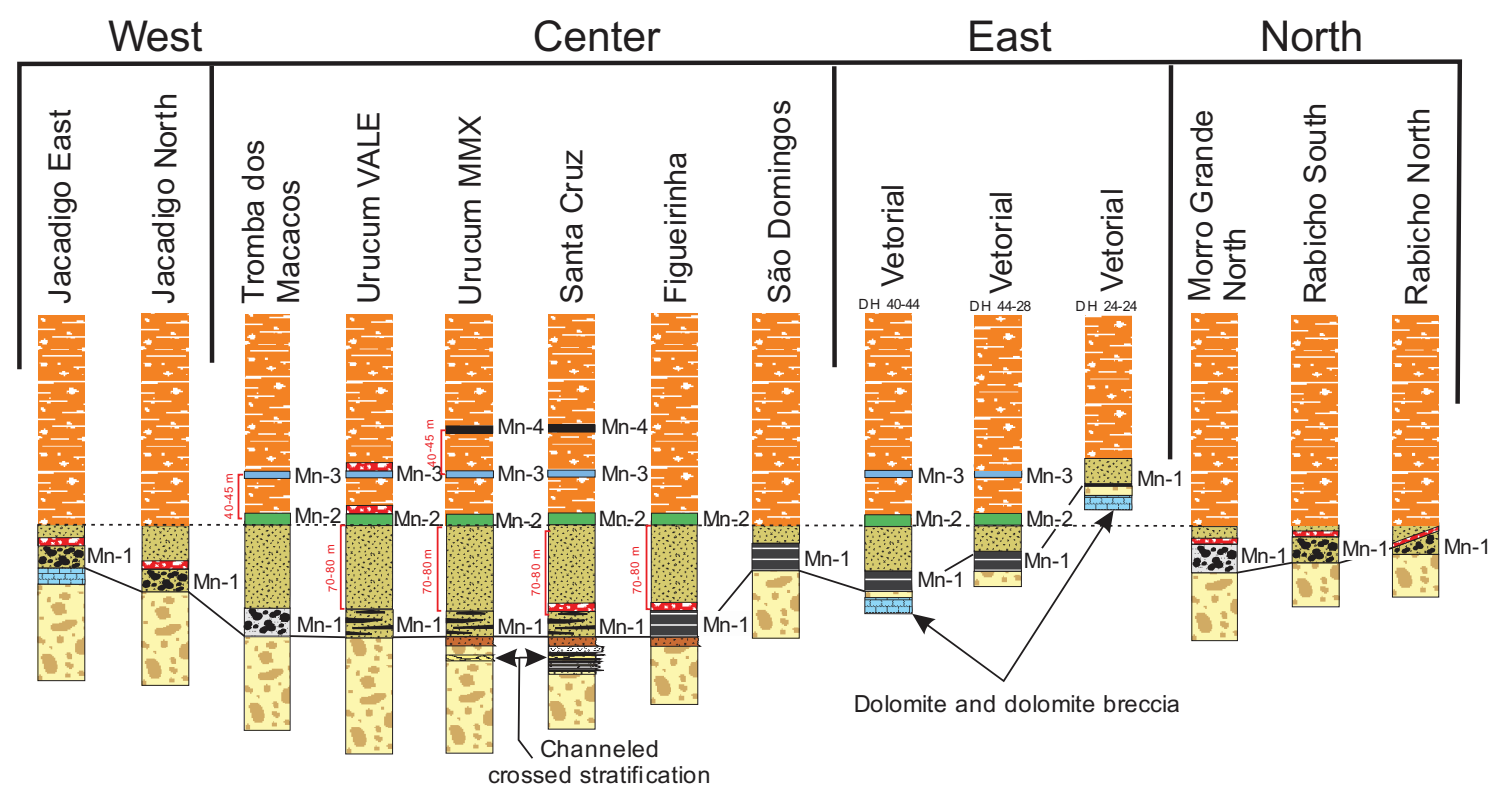

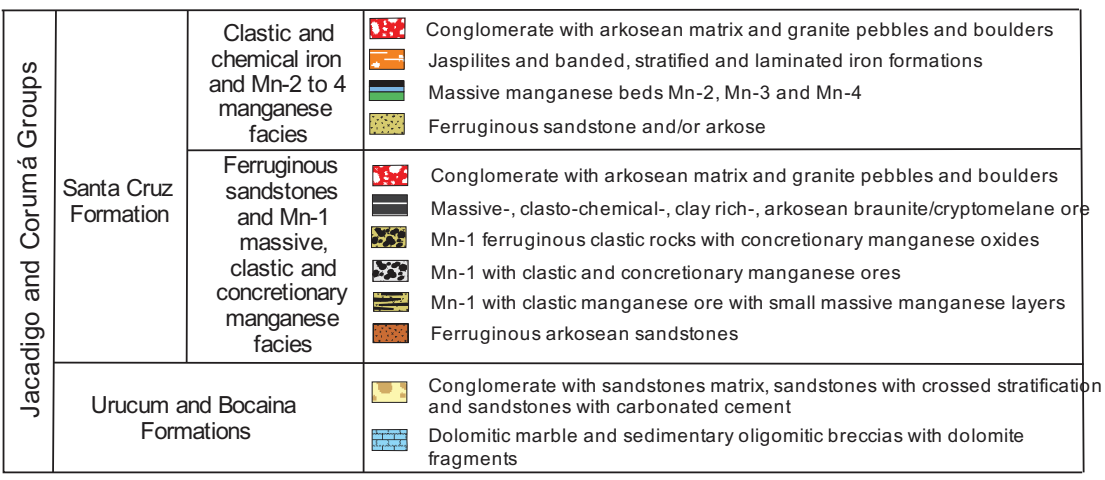

Stratigraphic columns of the Jacadigo Group, arranged from west to east passing through the basin depocenter. The stratigraphic columns of the Morro Grande Norte and Rabicho plateaus, located to the north of the basin, were positioned in the right part of the figure (modified after Urban et al. 1992, Biondi and Lopez 2017). The column elevations are normalized to the stratigraphic position of layer Mn-2 or, where this layer is absent, to the IF base. 


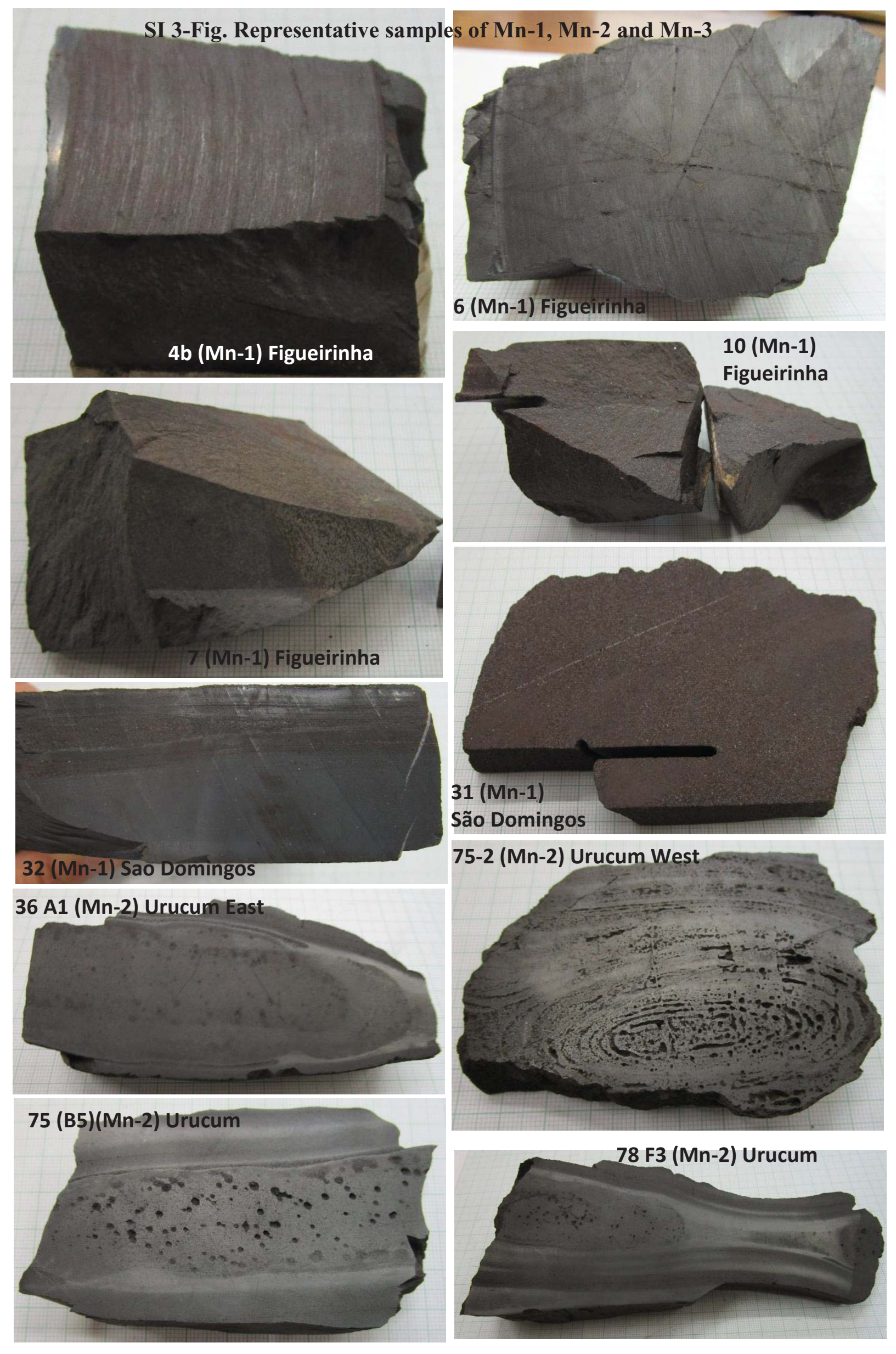



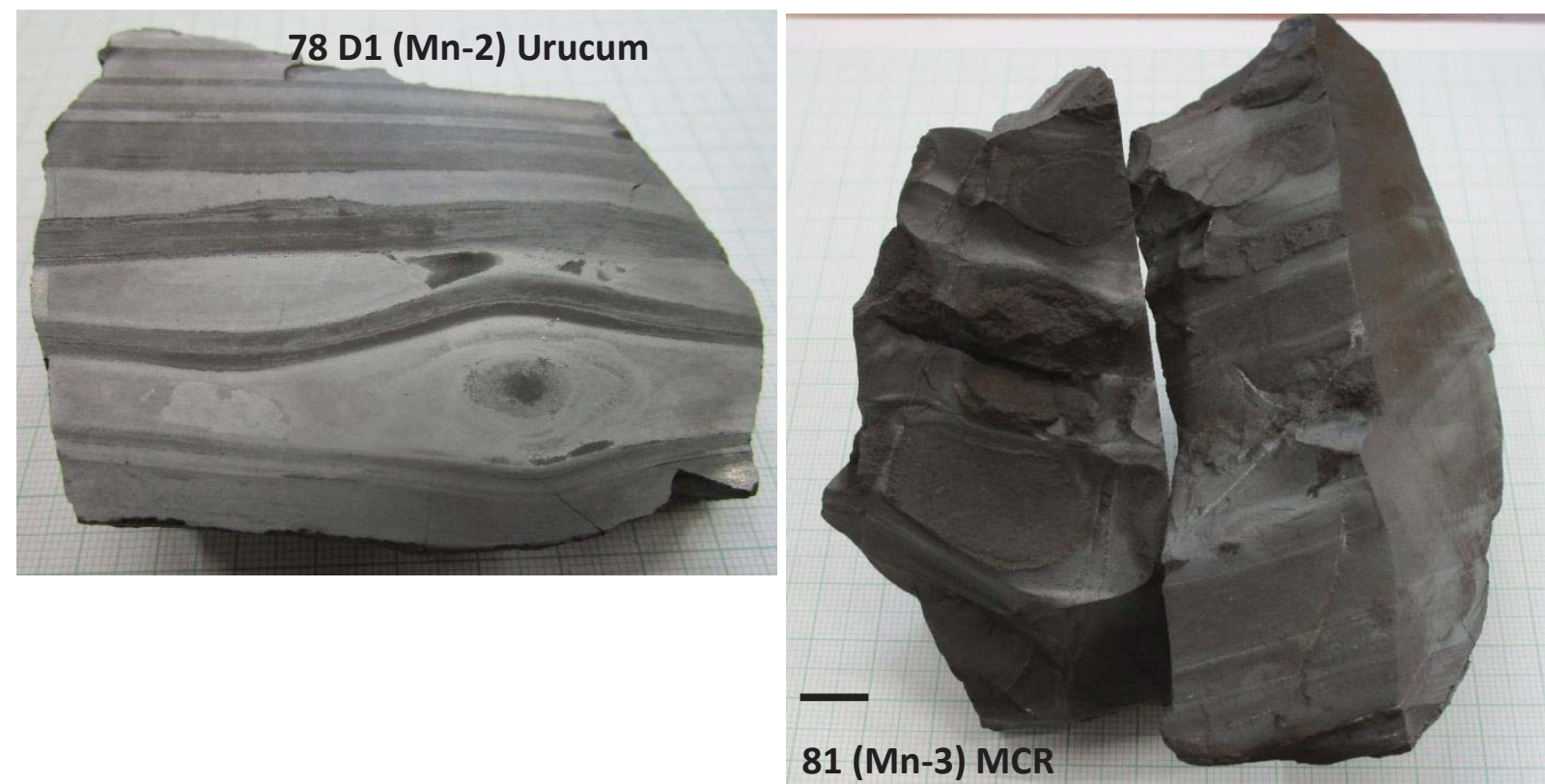

Cut samples

For details see Fig. 1-3 and Table 2.

Scale: $1 \mathrm{~cm}$ 


\section{SI 4-Fig. Pores and micro-channels in kremydilites}
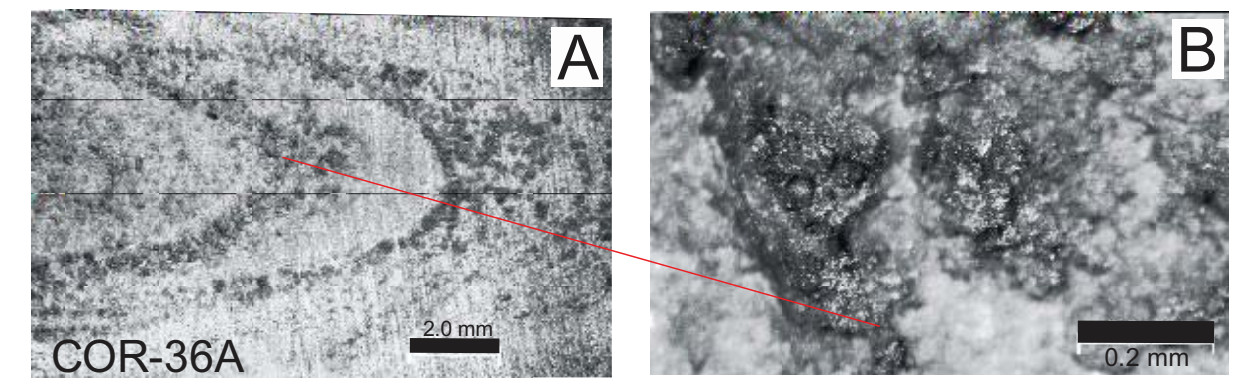

COR-48B

$34 \mathrm{~mm}$

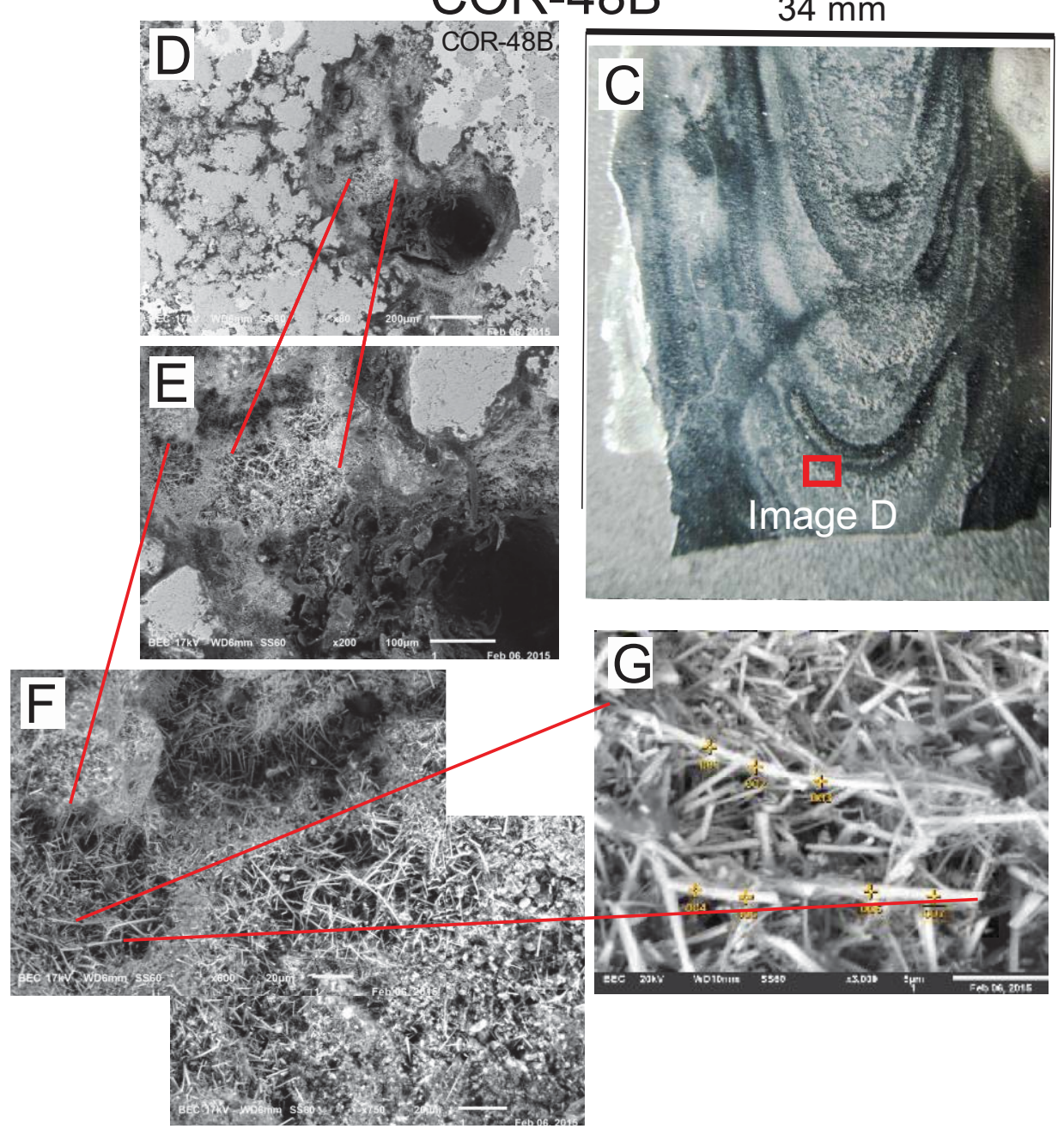

Pores and micro-channels in kremydilites. (A) A set of pores that delineate the micro-layers that surround the nucleus. (B) Pores covered by acicular microcrystals of cryptomelane. (C-G) Micro-channels enveloped by acicular microcrystals of cryptomelane (image $\mathrm{C}=$ polished section; images D to G obtained with SEM - Scanning Electron Microscopy)(Biondi and Lopez 2017) 


\section{SI 5-Fig. Structure of kremydilite}

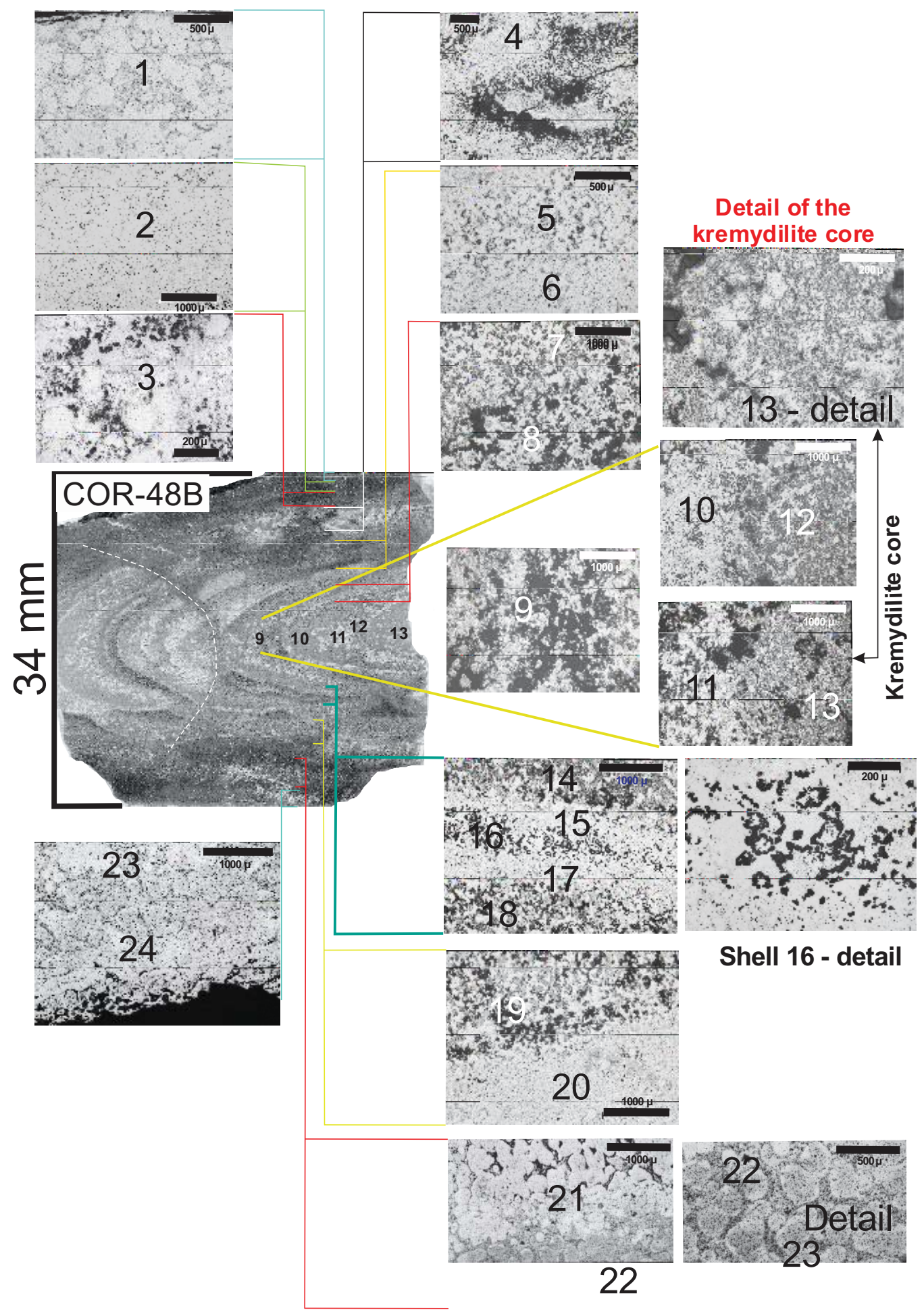

Polished section of the sample 48B showing the bands or sheets of Mn-3 layer in between kremydilite formed (zones 1, 2, 3, and 20 up to 24). Surrounding the core are the most distant concentric micro-layers, shells (shells 4, 5, 6 and 14 to 18) and the nearest ones (shells 9, 10 and 11). Shells 12 and 13 are in the core of the structure. See text for details (Biondi and Lopez 2017). 
The curved and undulating layers (bands) in which kremydilite formed are composed of flakes whose diameters ranged from 0.8 to $0.2 \mathrm{~mm}$ (SI 5-Fig, zones 1, 2, 3; and zones 20 to 24), apparently composed by the amalgamation of flakes, micronodules smaller than $10 \mu \mathrm{m}$ (Fig. $4 \mathrm{~K}$ ). The outermost zones (shells) of kremydilite (SI 5-Fig, shells 4, 5, 6, and 14 to 18) consist of anhedral and irregularly shaped minerals, looking like amalgamated flakes. In these shells the presence of ring-like structures, composed of dark carbonate microcrystals are common (SI 5-Fig, shell 16 - detail image). The shells closer to the nucleus $(9,10$ and 11) are also composed of mixed anhedral, metallic minerals, but with larger dimensions than the anterior shells. The nucleus of the kremydilites (zones 12 and 13) are microgranular and with homogeneous appearances. 
SI 6-Fig. Panorama images of the analyzed samples
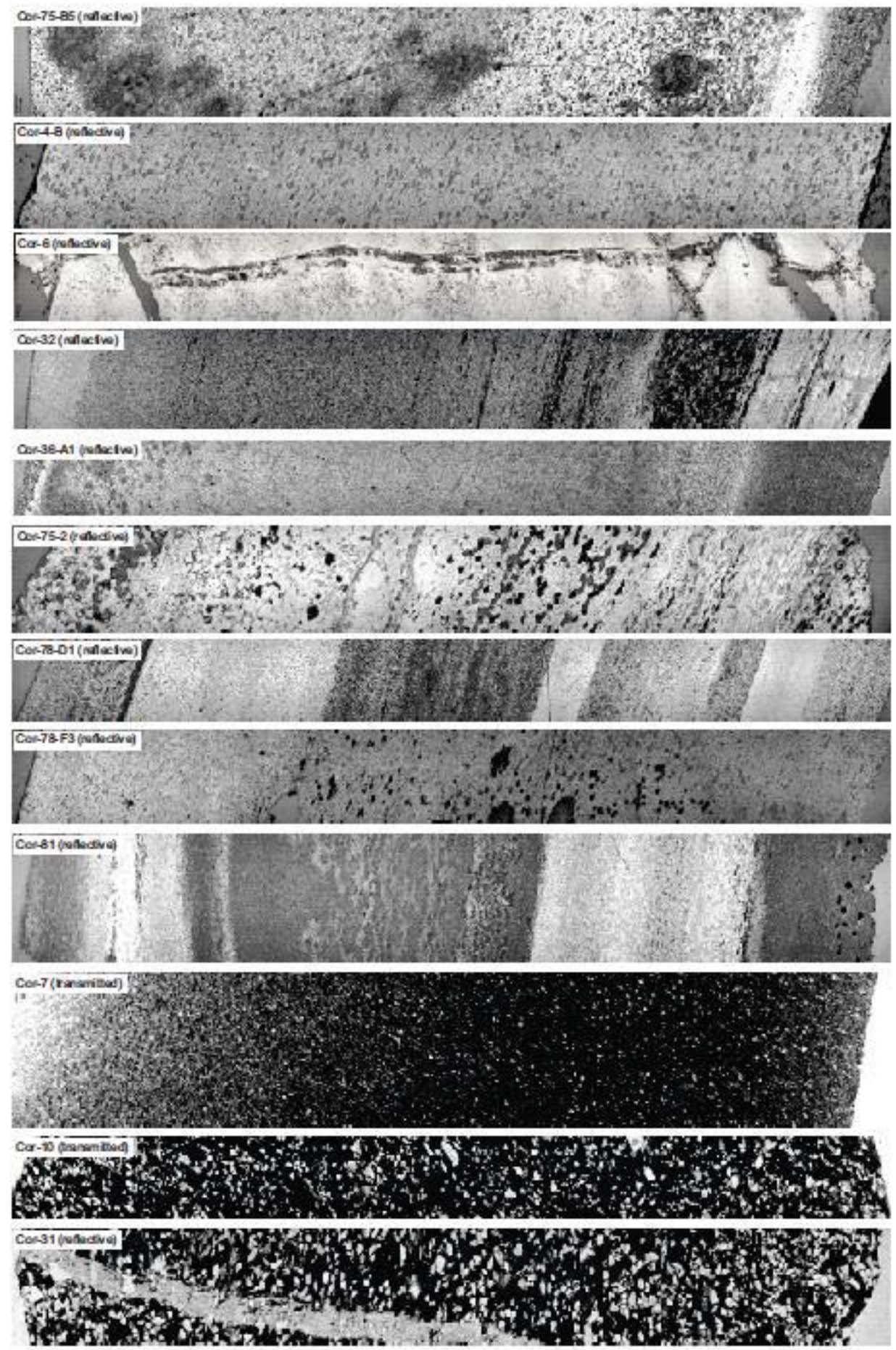
SI 7-Fig. Biomat structures of representative samples (arrows)

Optical rock microscopy, reflected light, 1 Nicol (left side) and crossed Nicols (right side)

Sample 32
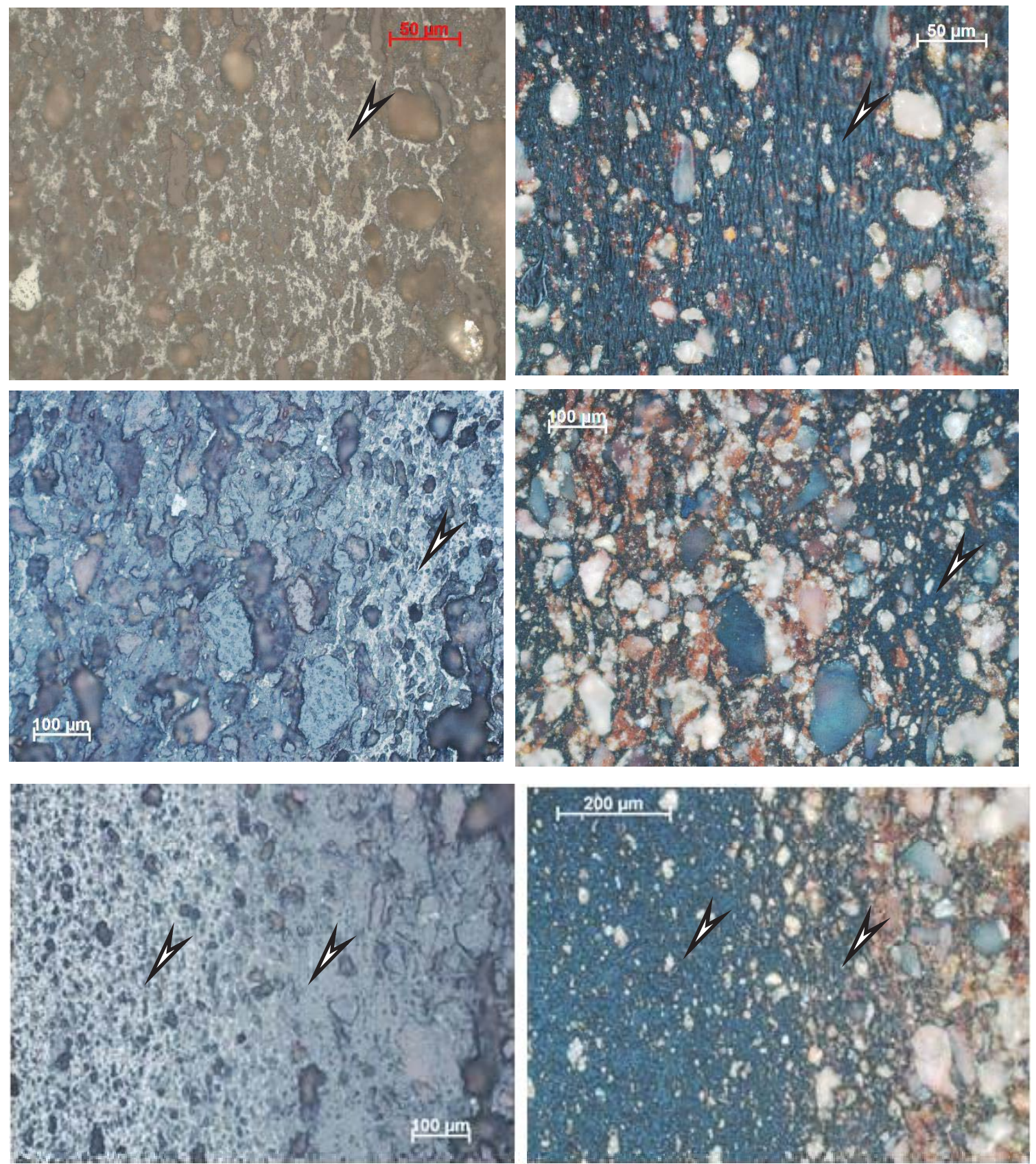


\section{SI 8-Fig. Microtexture of samples by optical rock microscopy \\ Sample 4B}
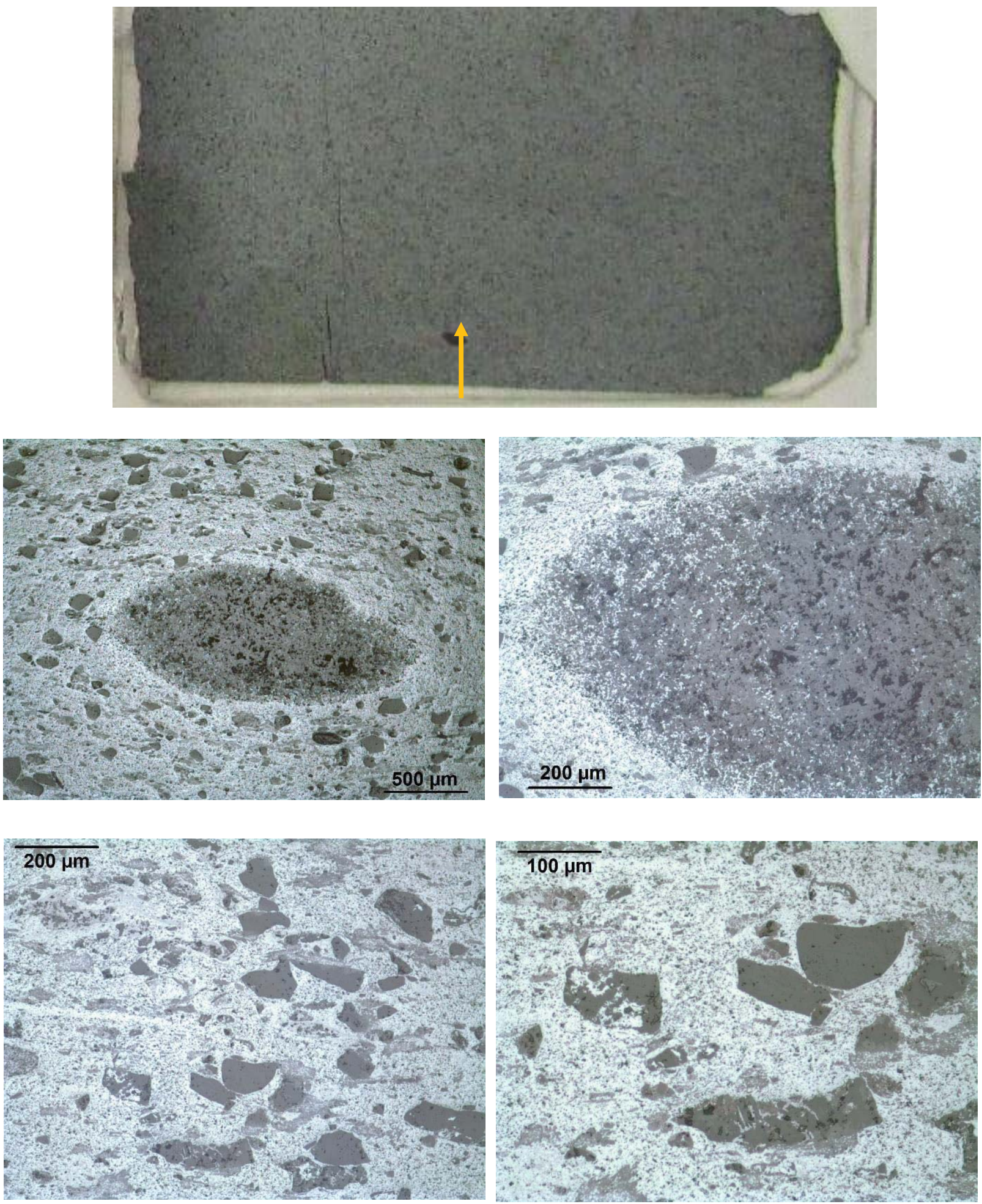


\section{Sample 7}
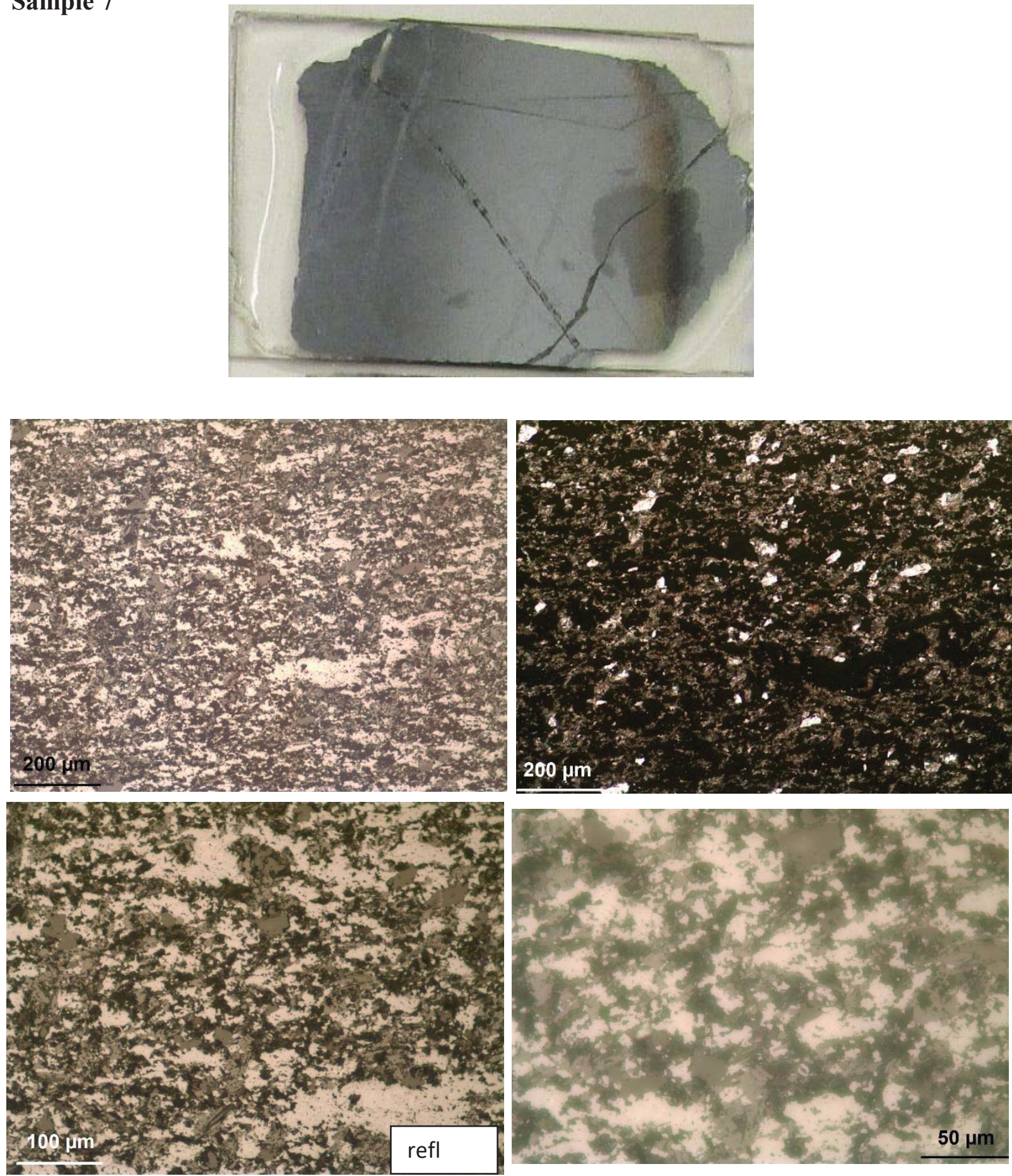

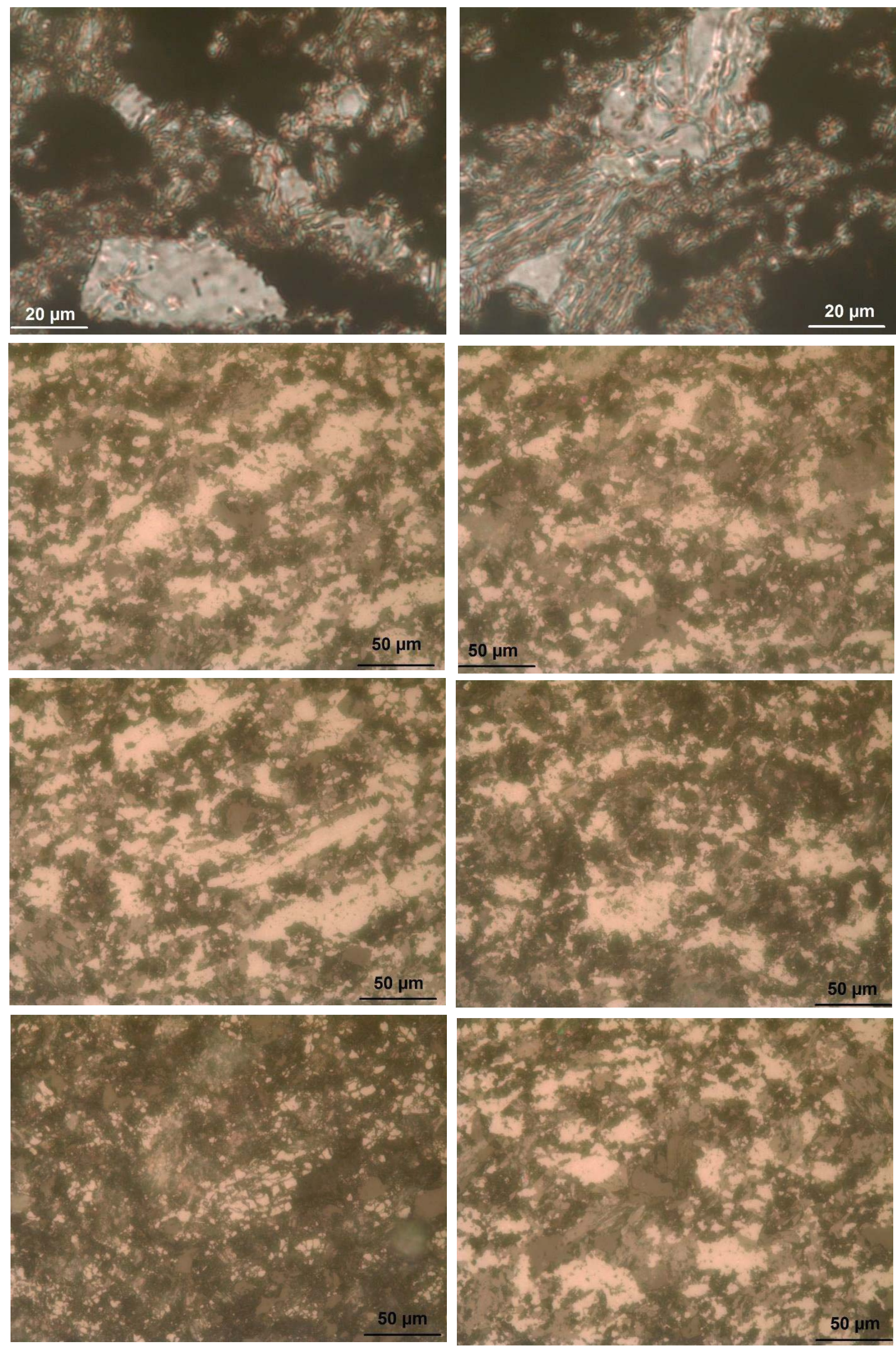

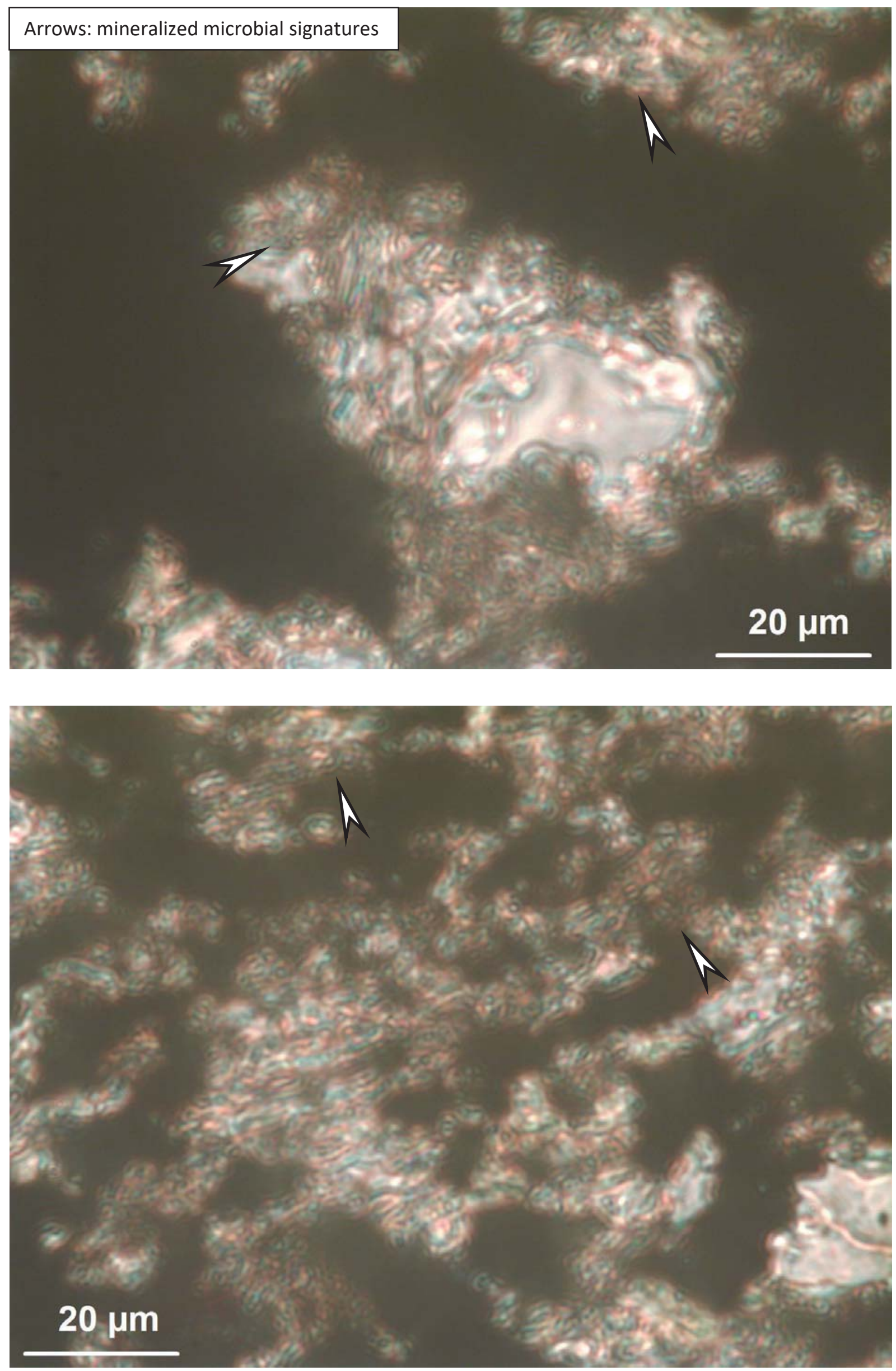

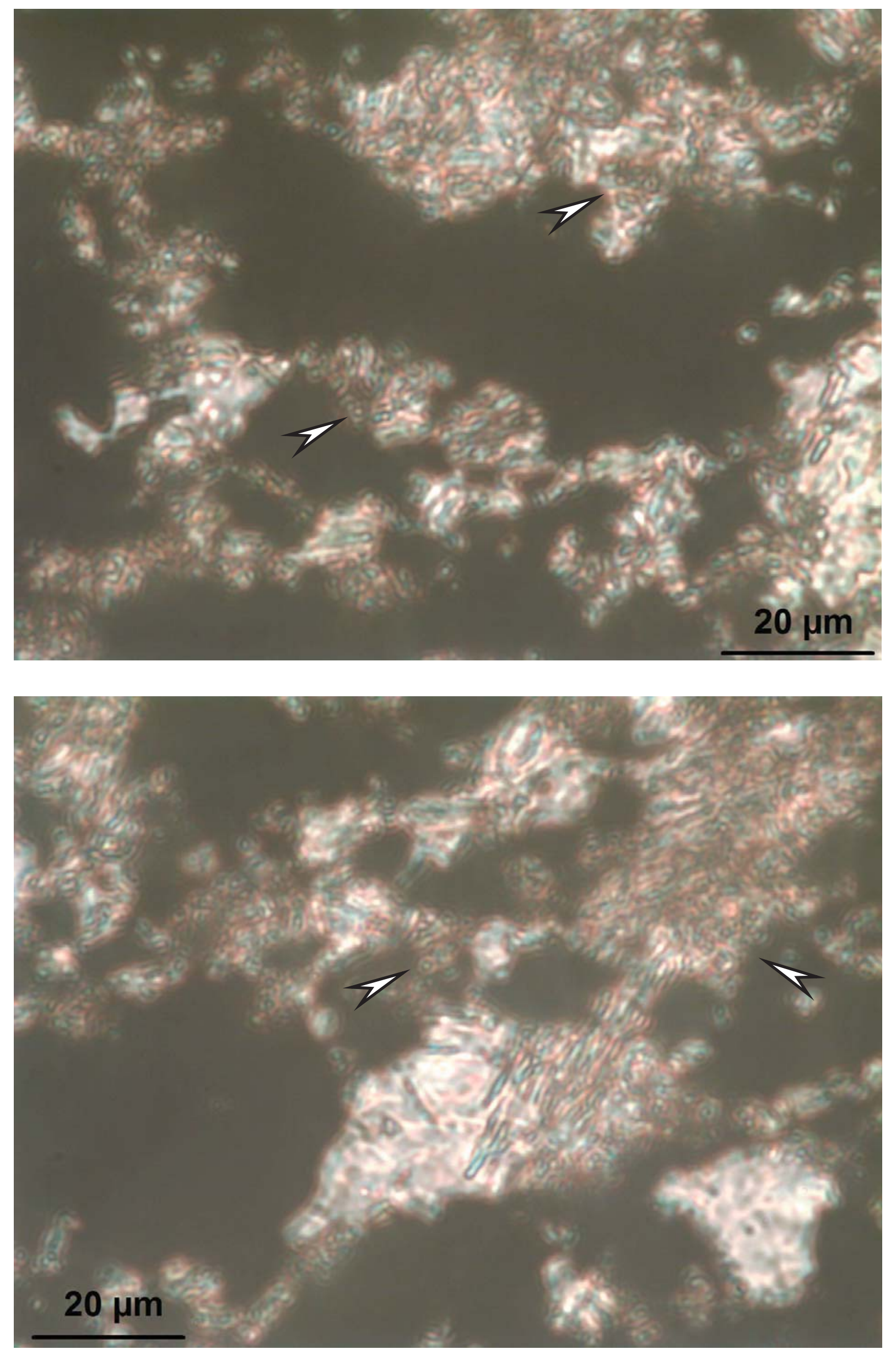

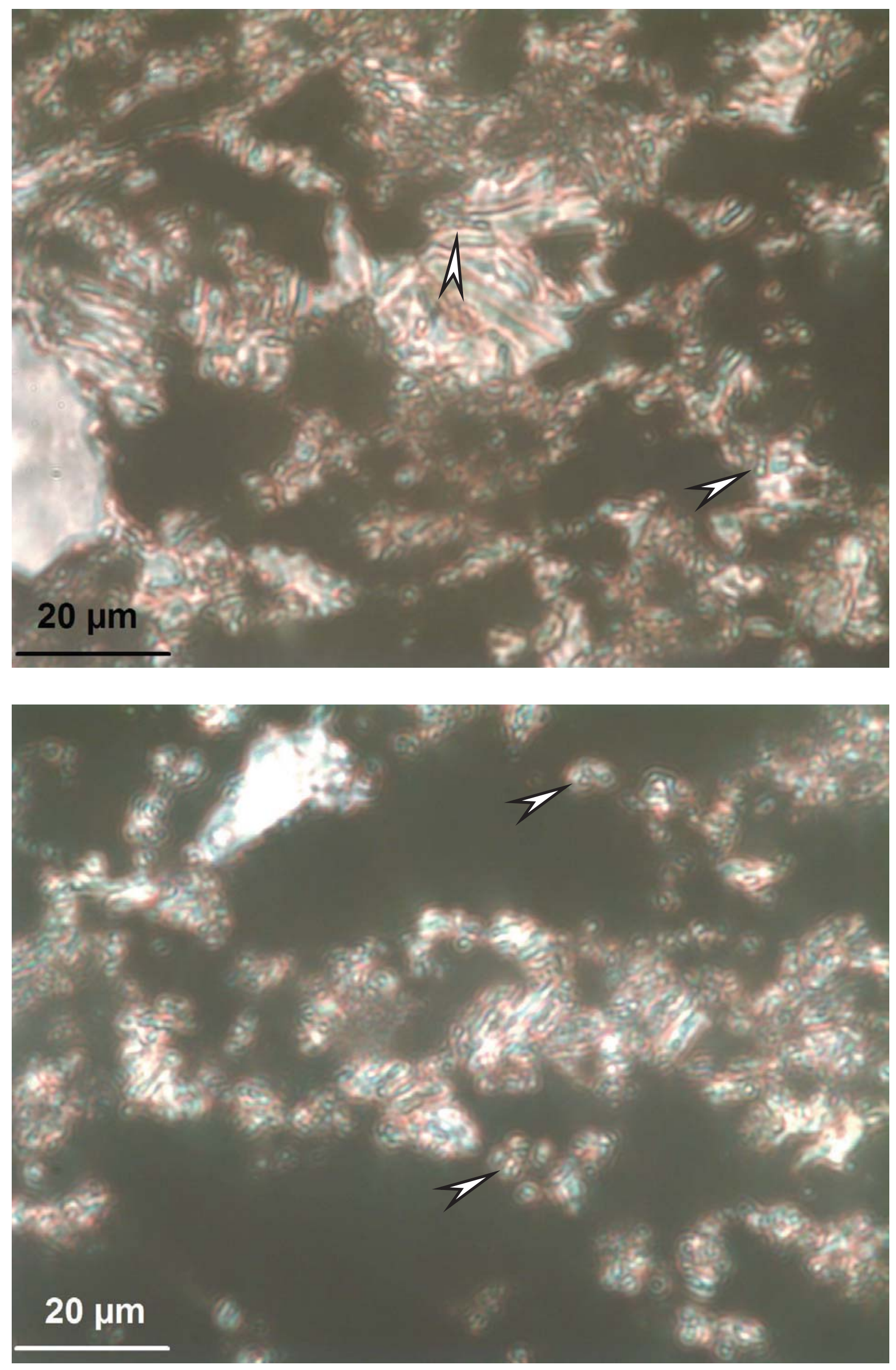

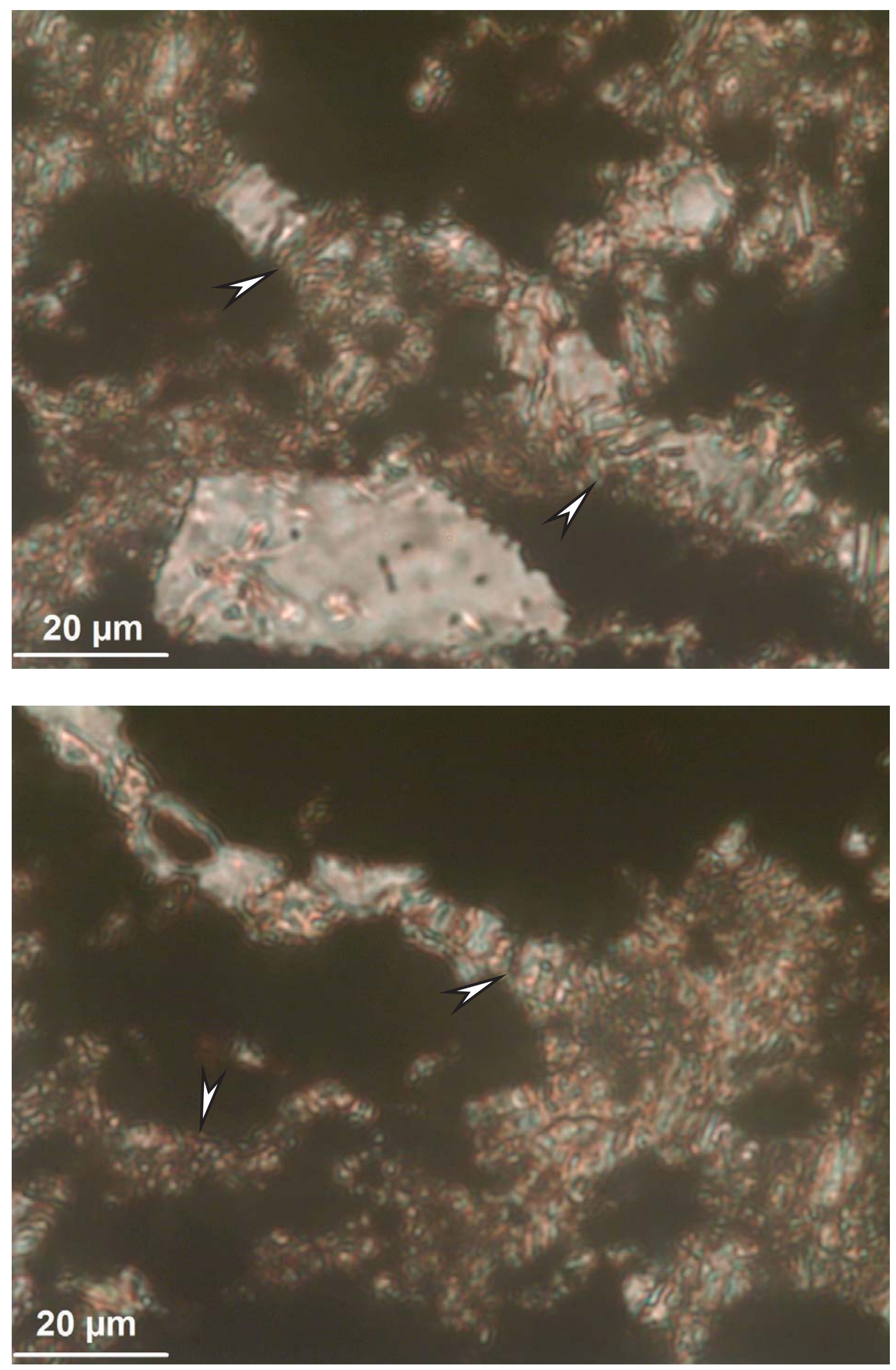

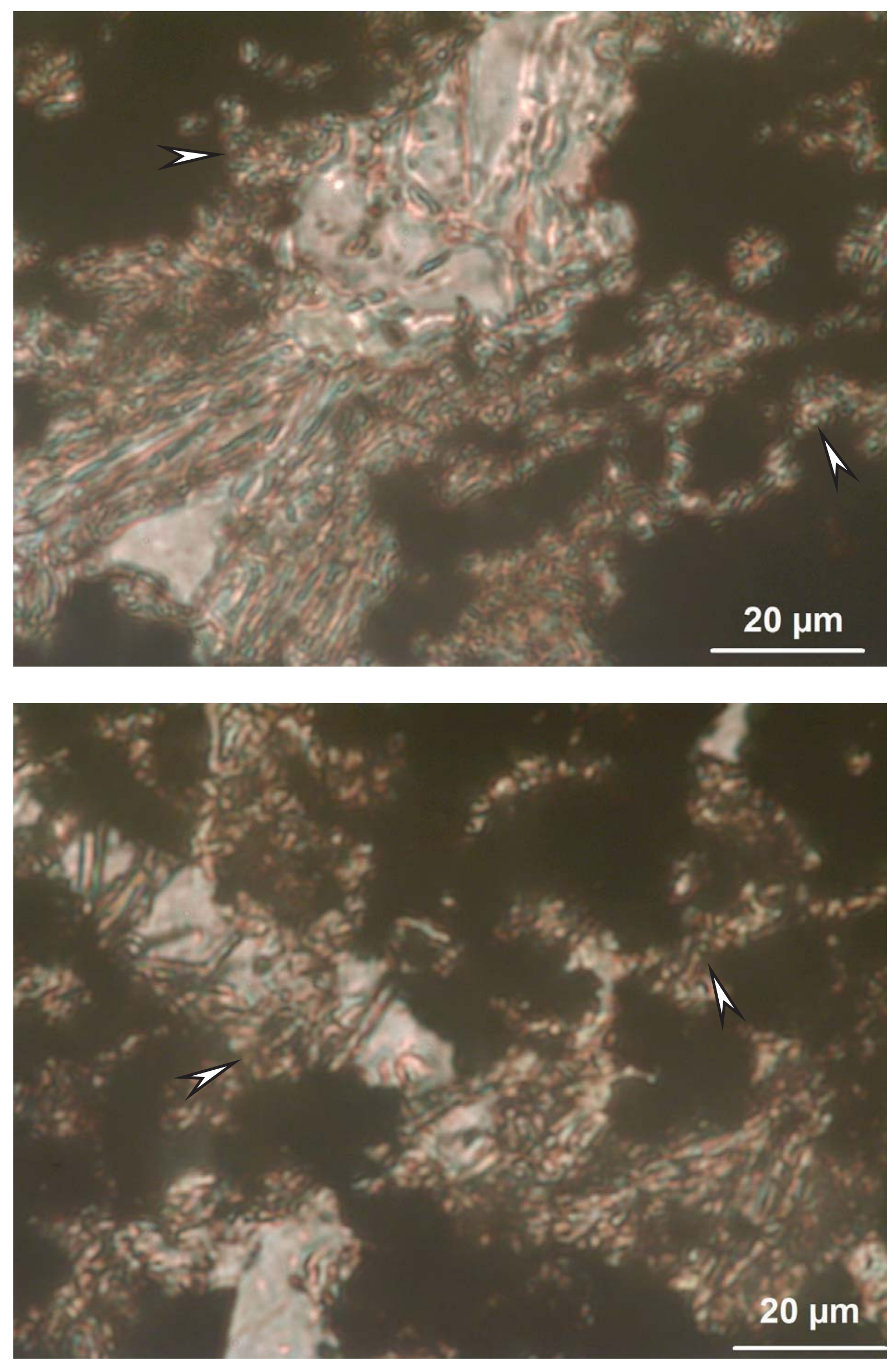
Sample 10
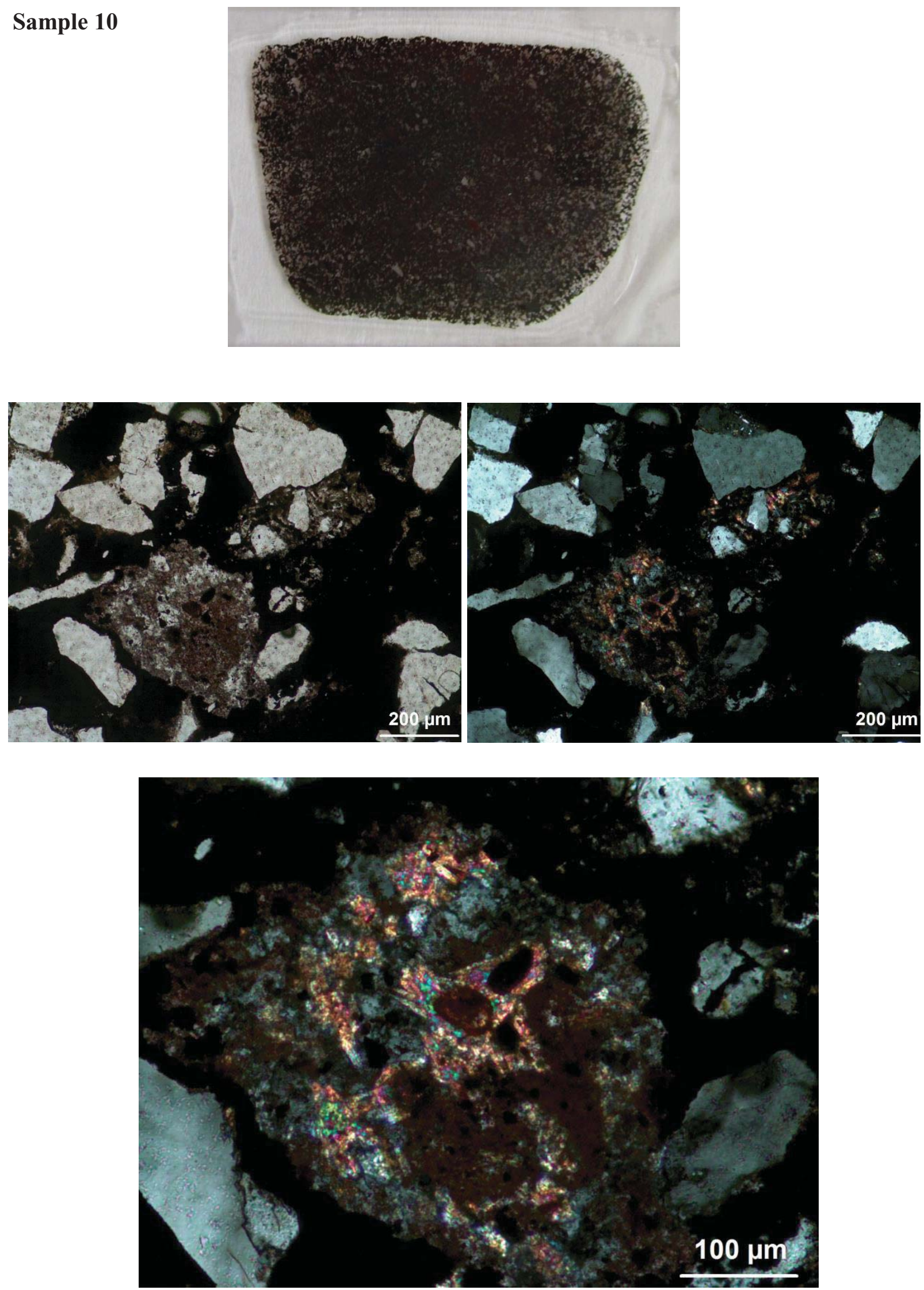

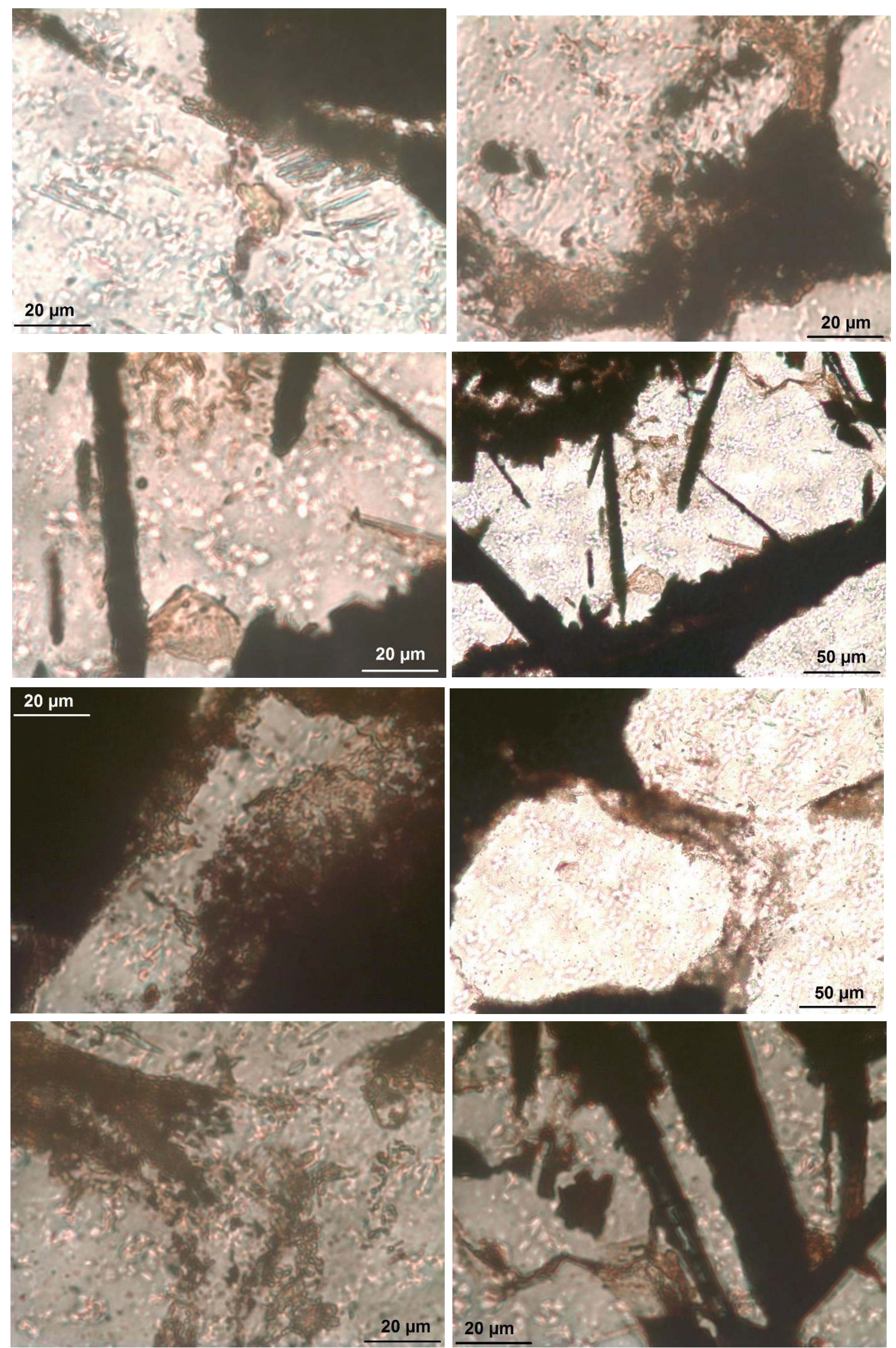

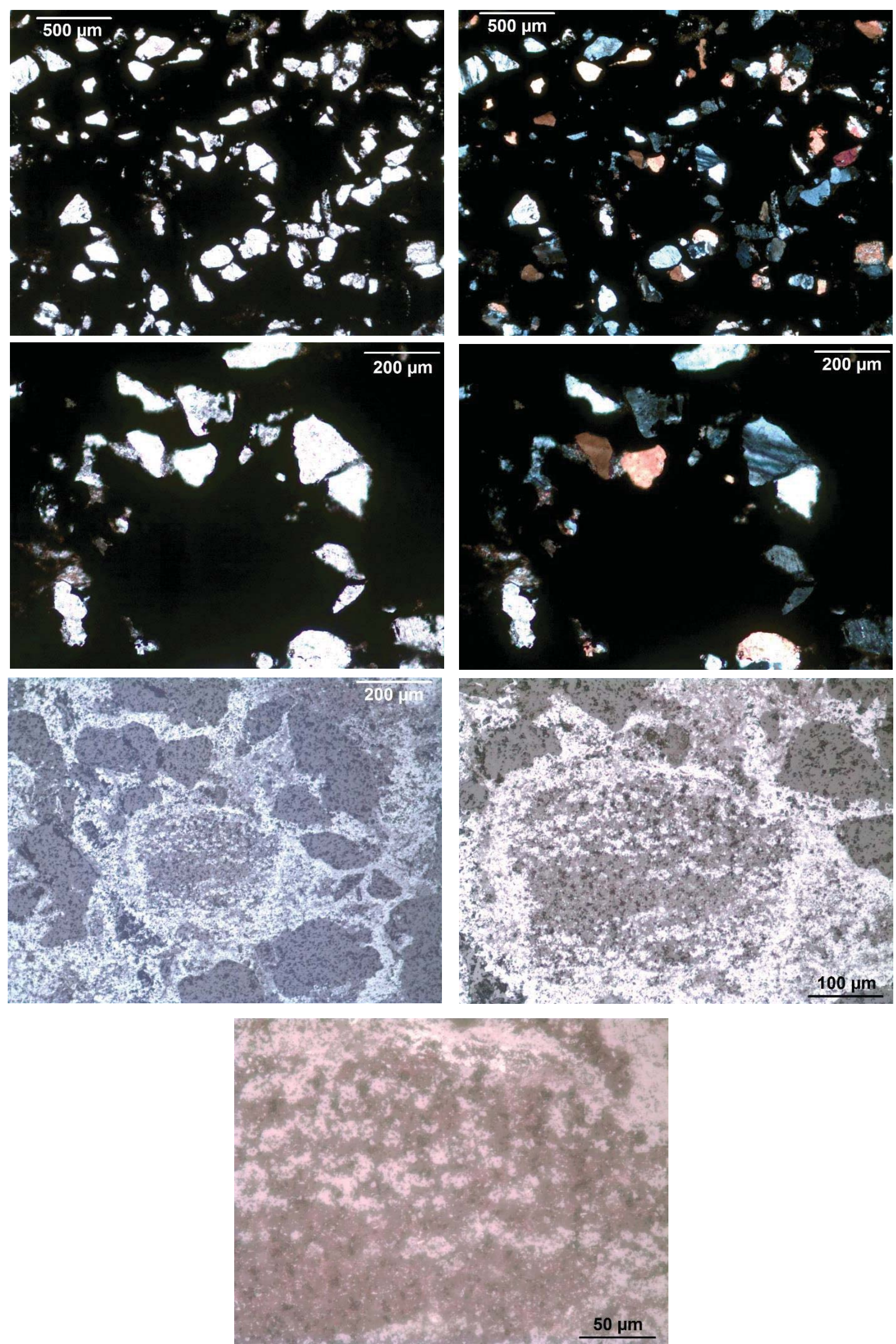


\section{$20 \mu \mathrm{m}$}
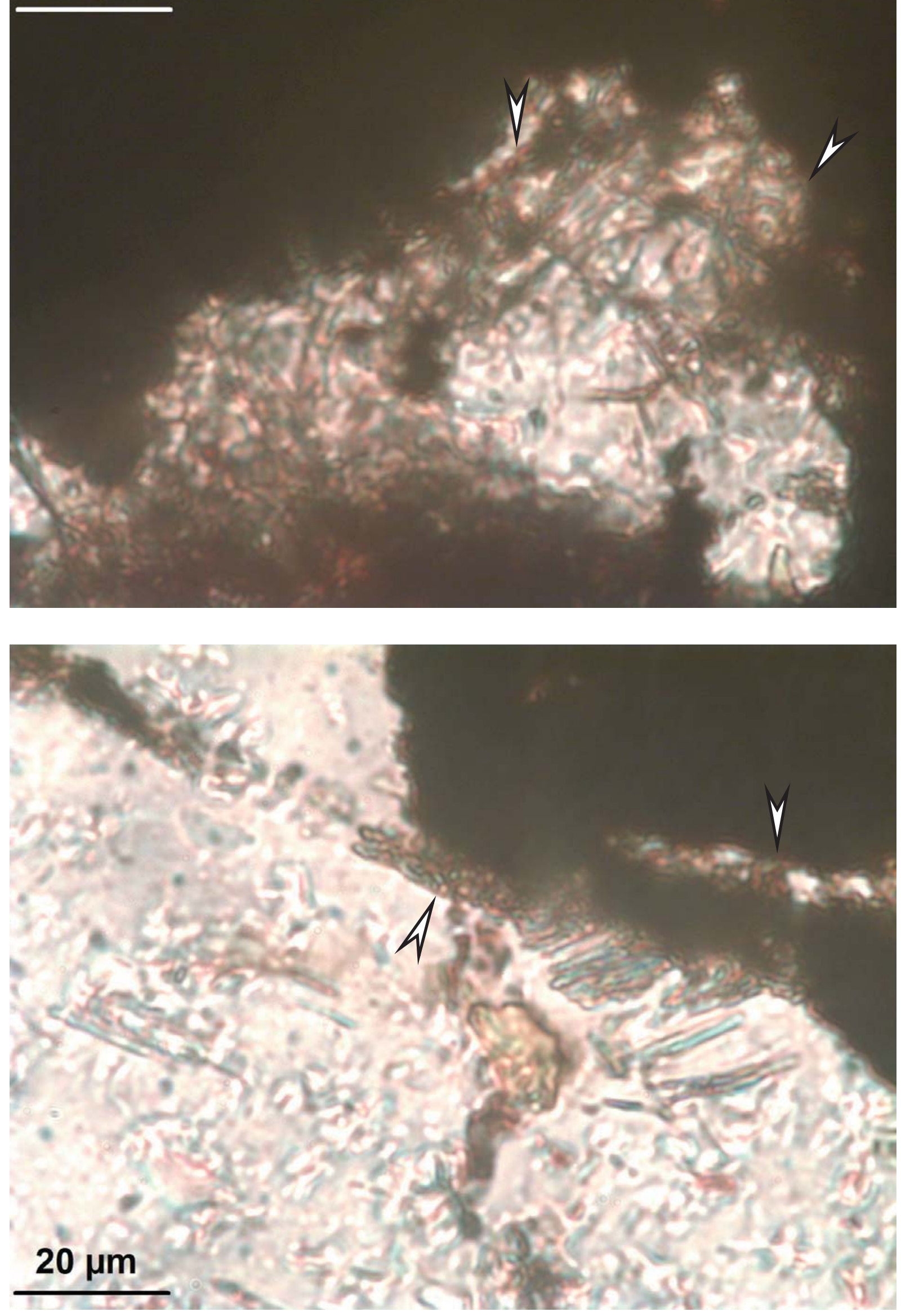

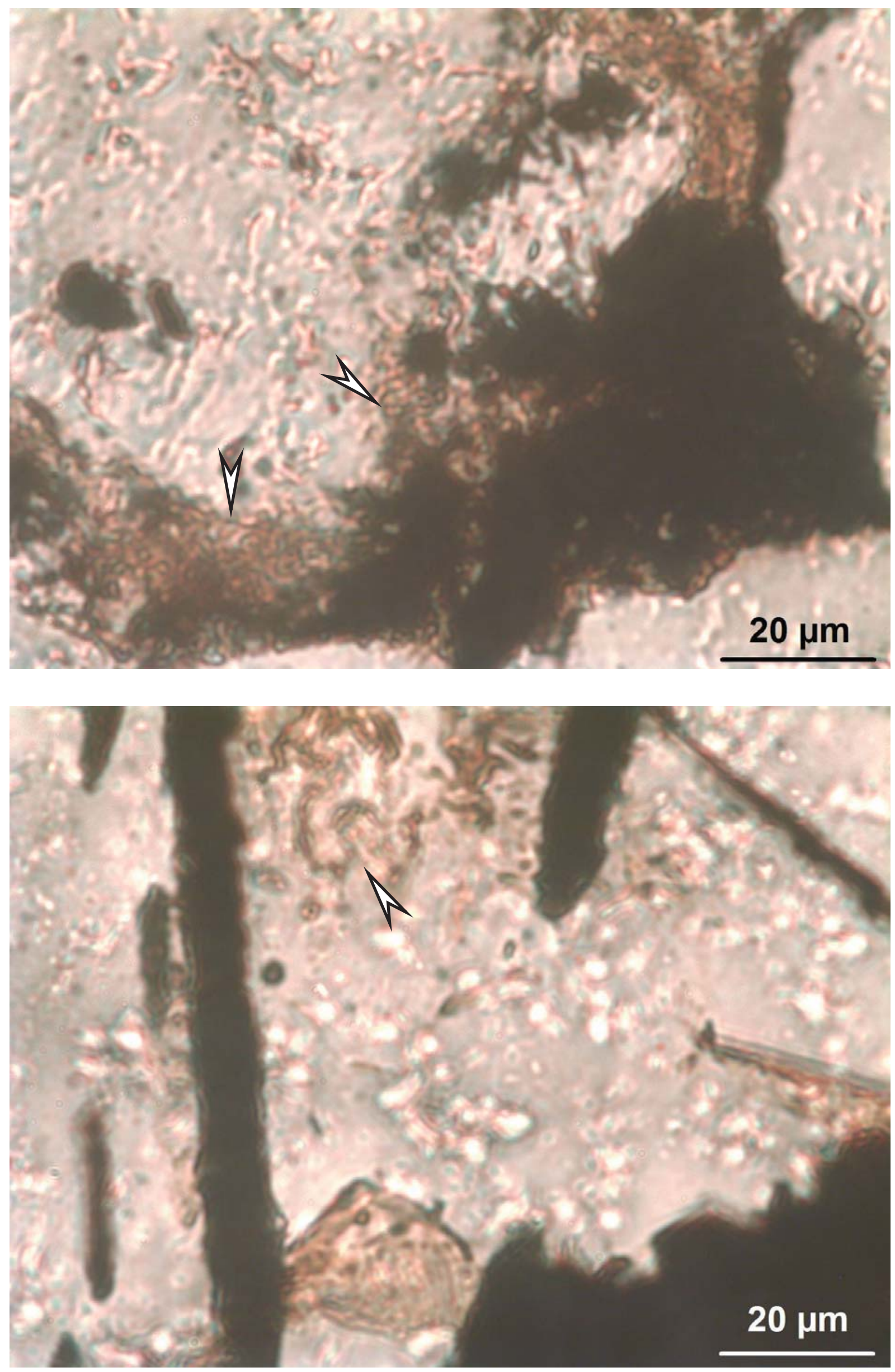

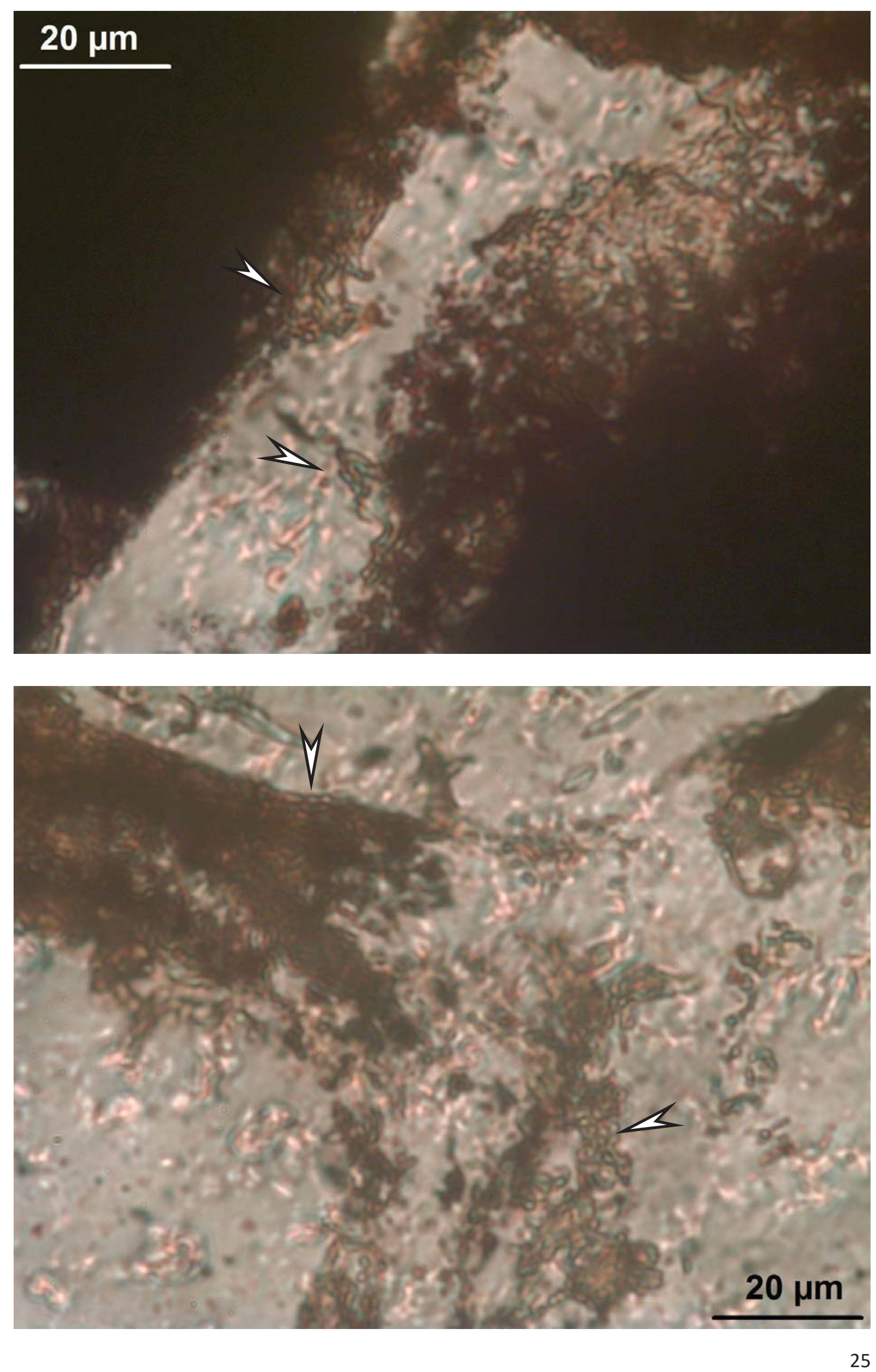

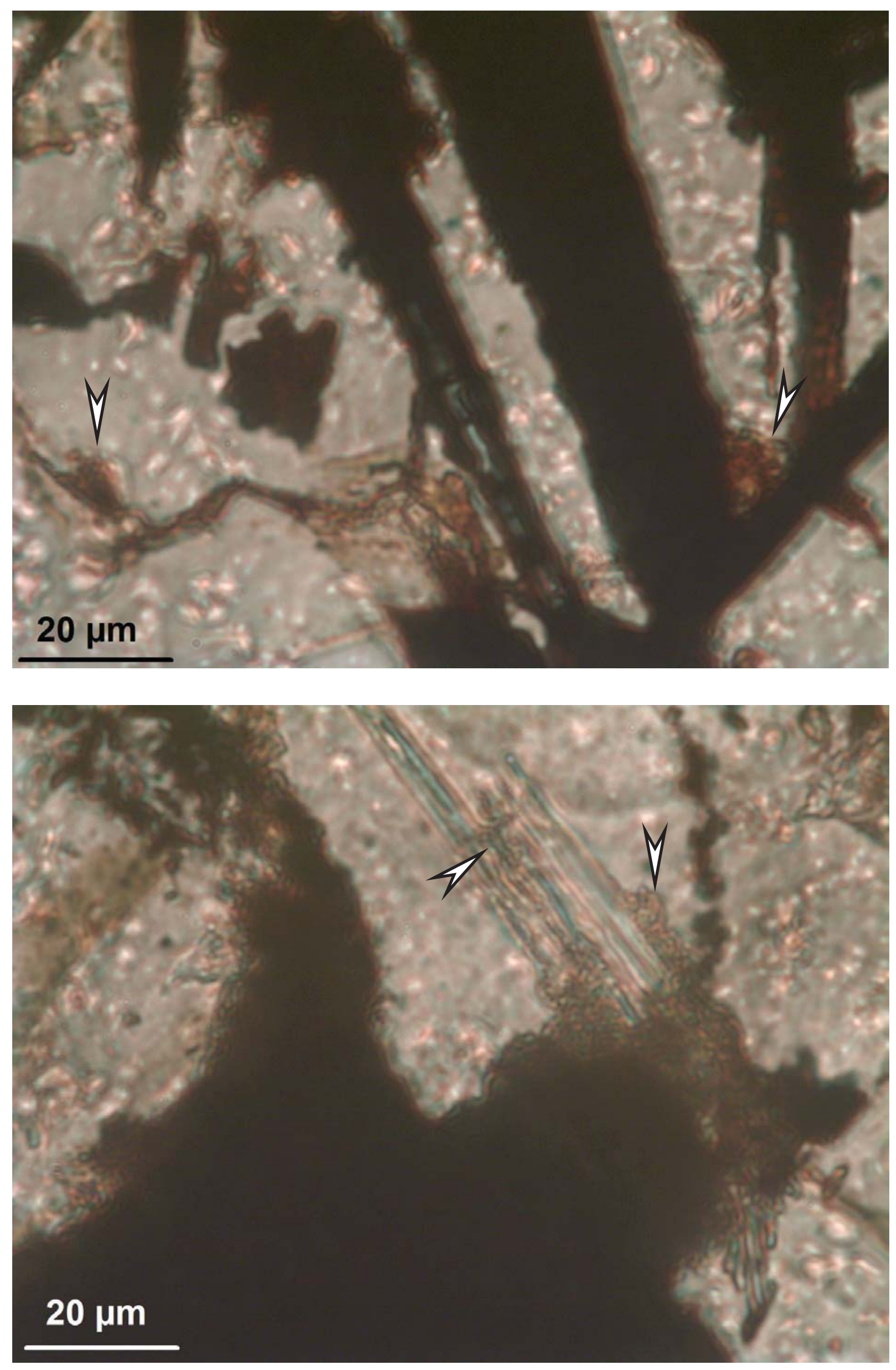

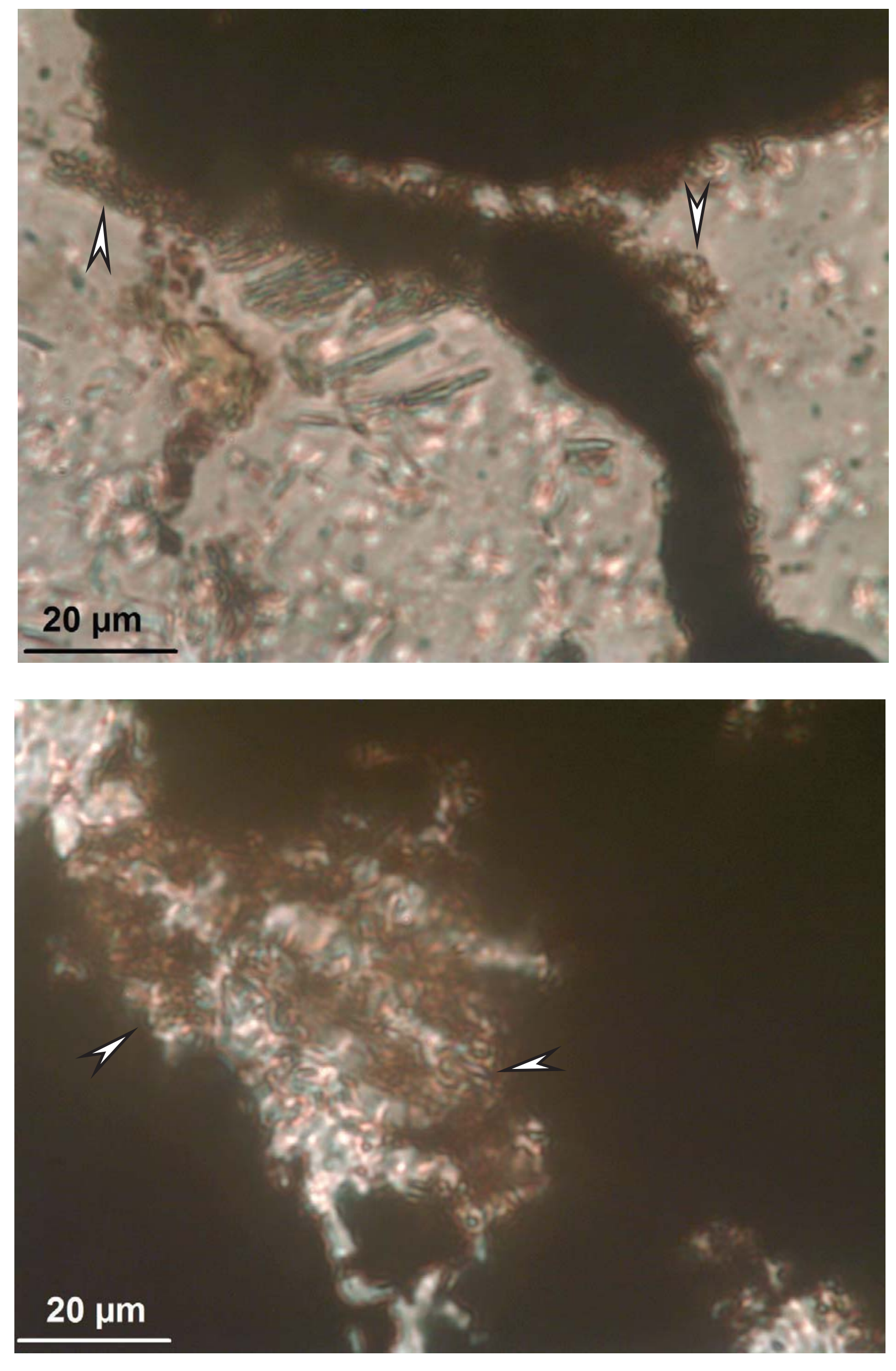


\section{Sample-32}

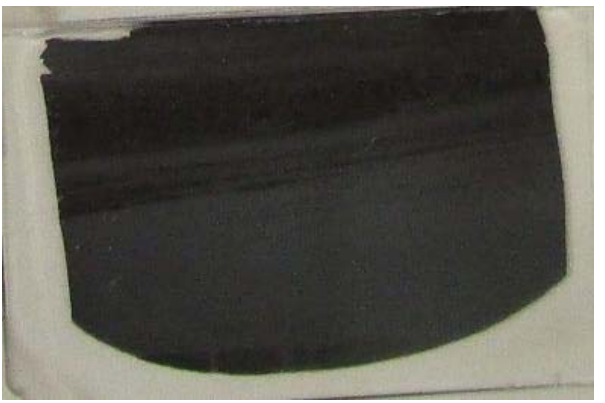

The sample is opaque, but at some places we can look into the material, and microbial signatures are well visible. The reflective photos also show dense microbial mediation. Also, cyanobacteria-like forms are visible. The opaque part is a very dense microbially mineralized material.
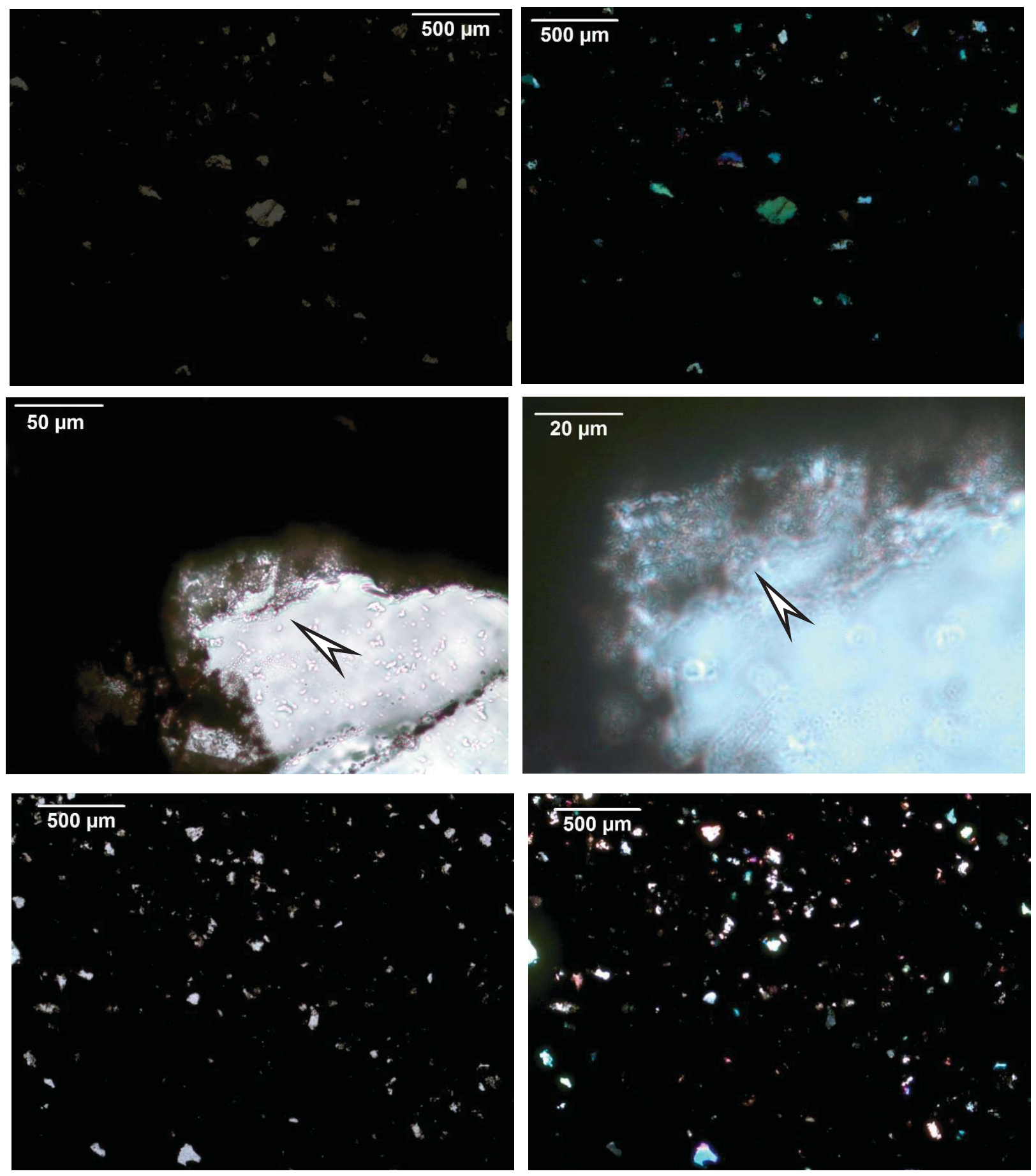

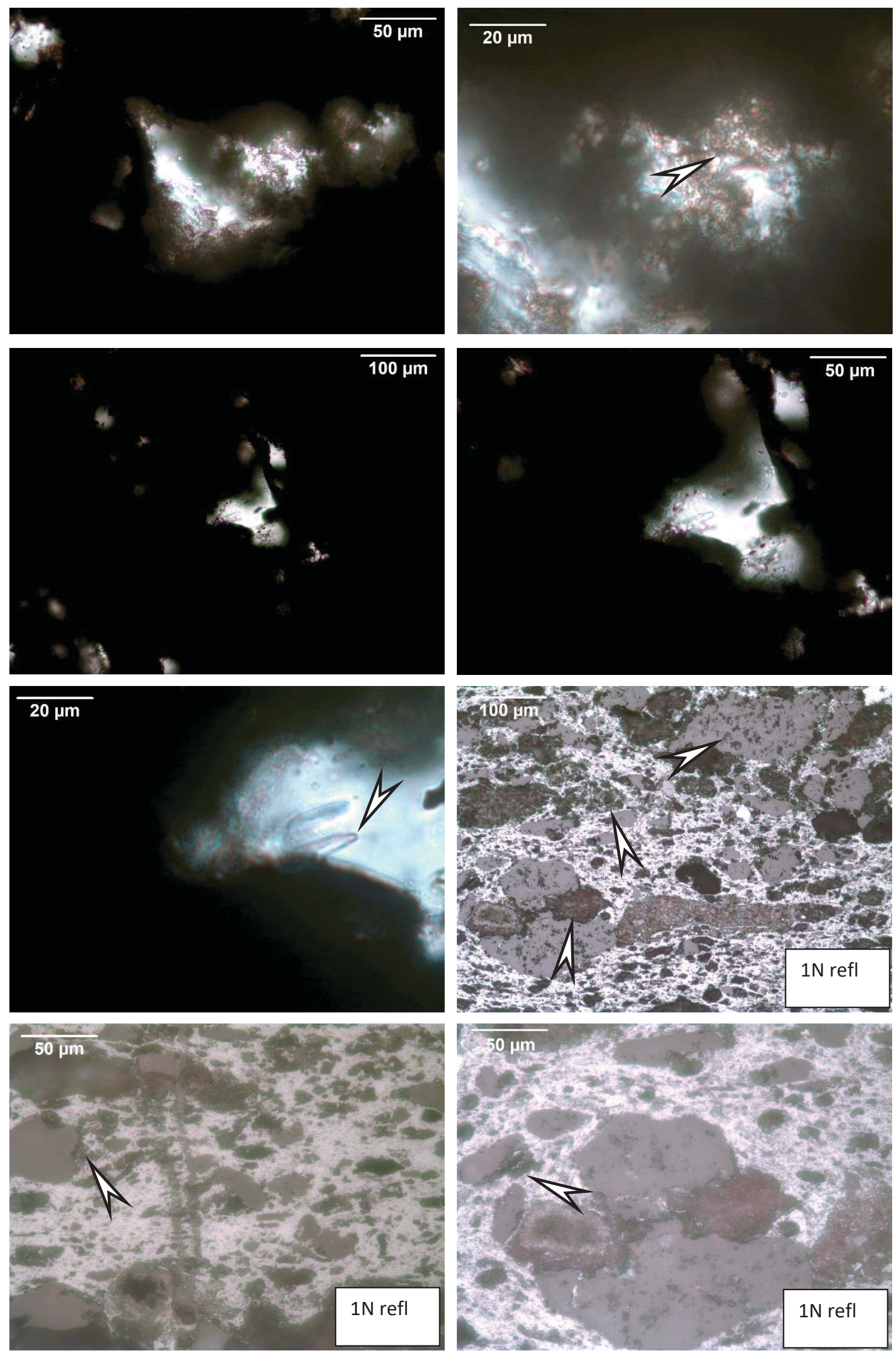


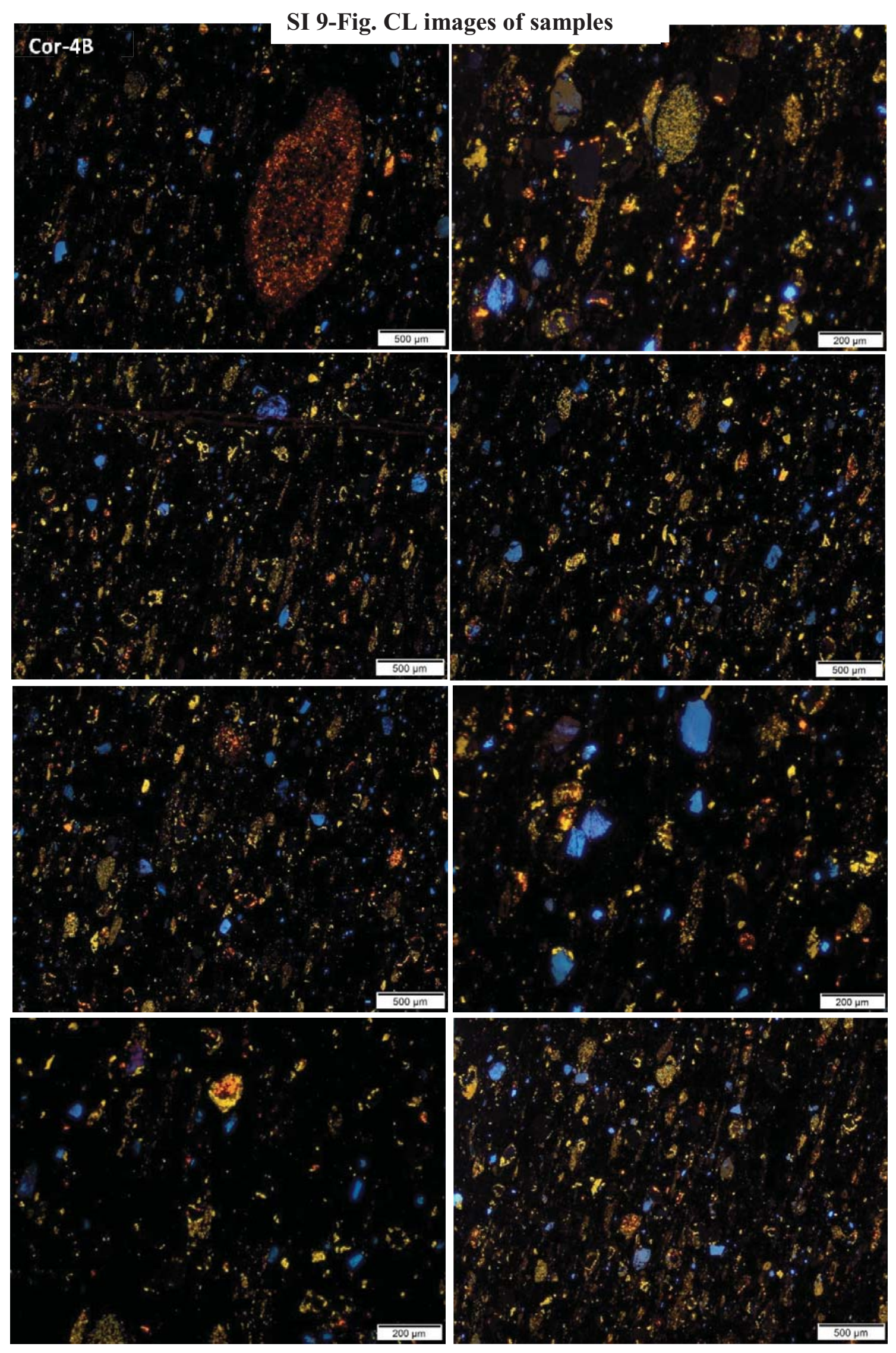




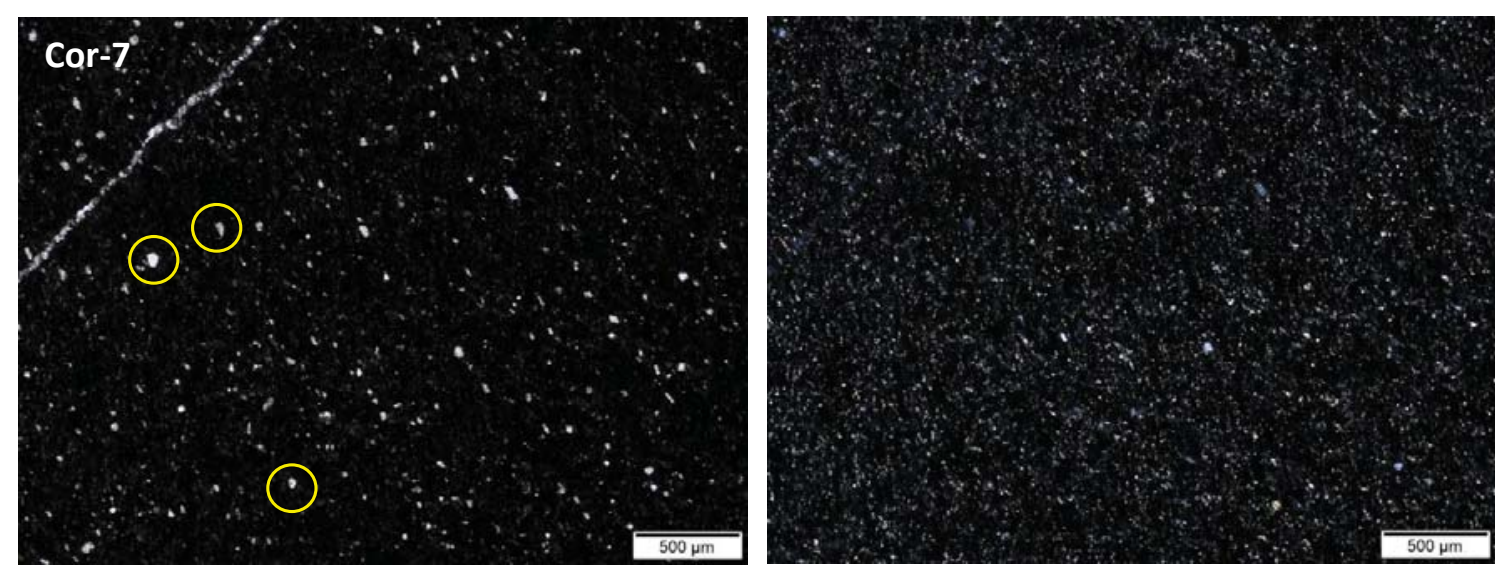

dull: non lumin.

yellow: apatite

blue: „dickite”

orange: carbonate
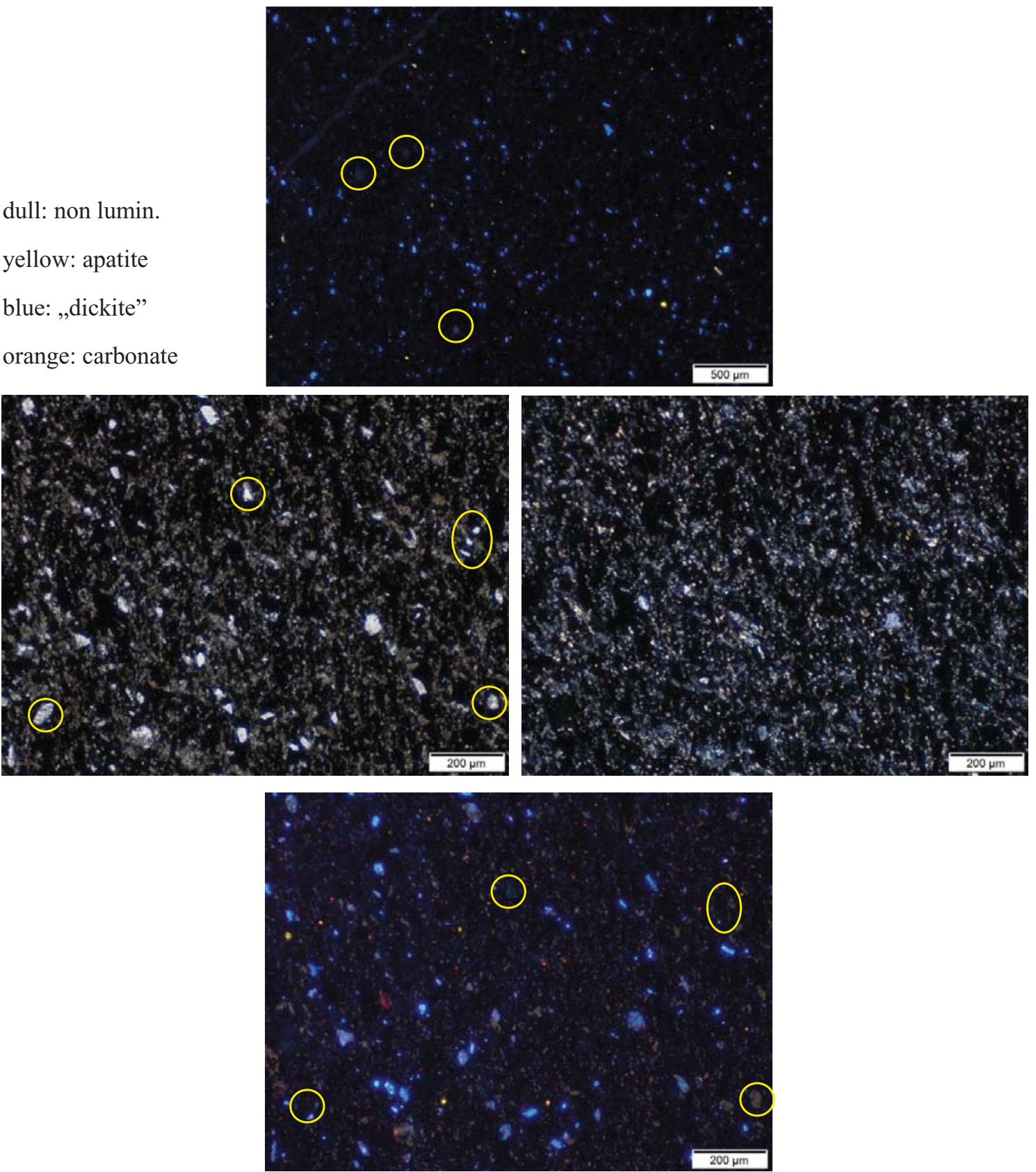

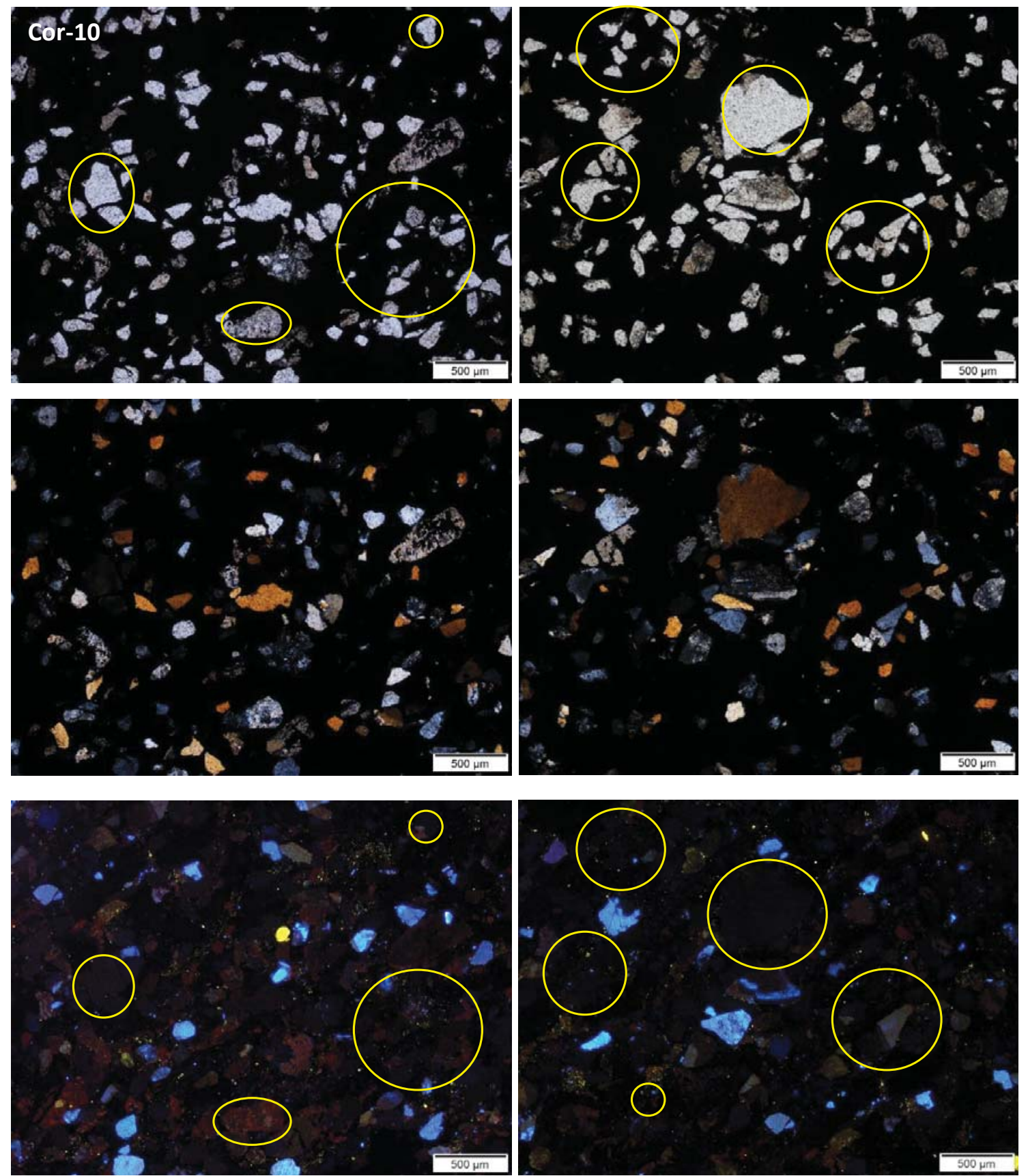

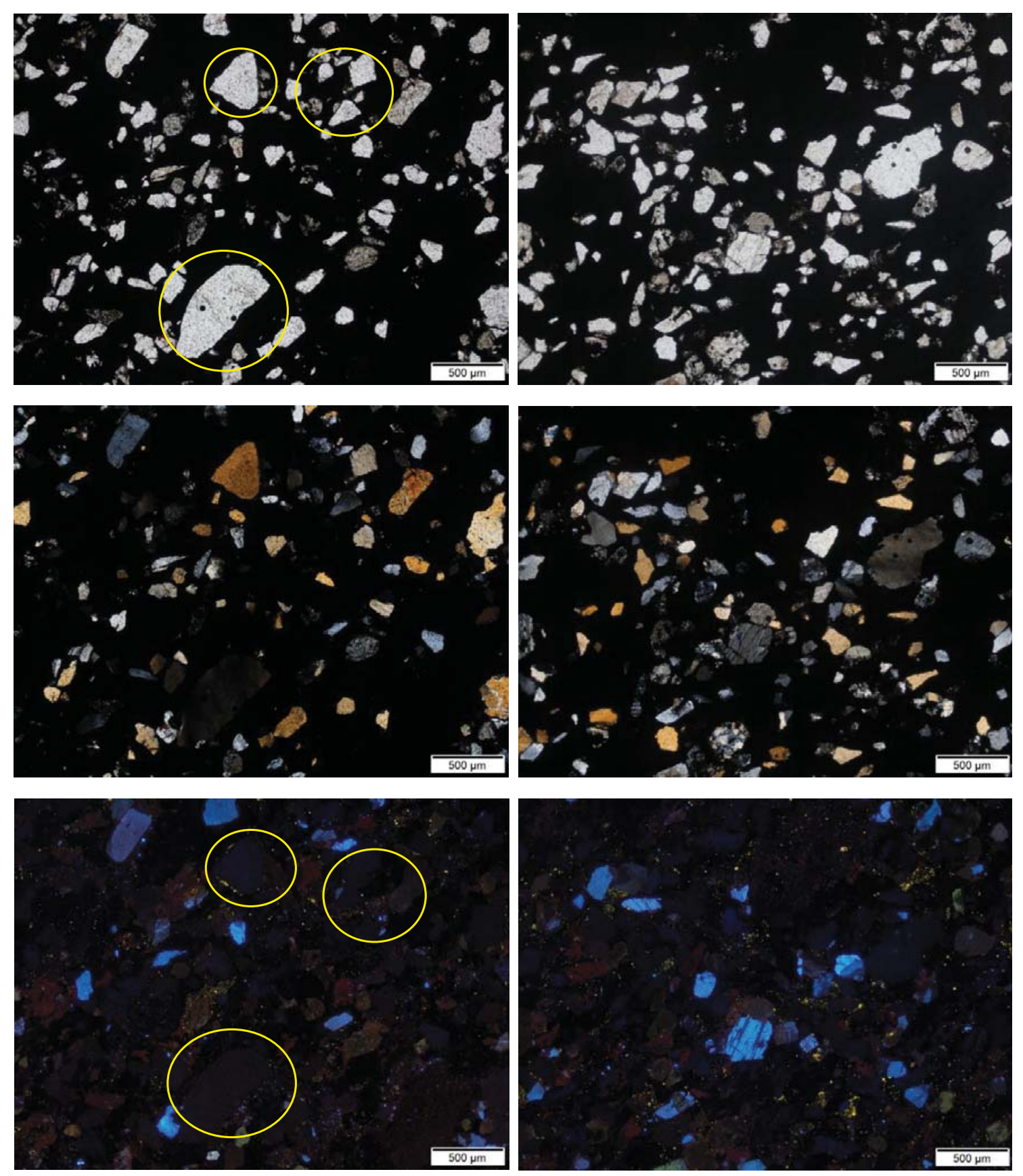

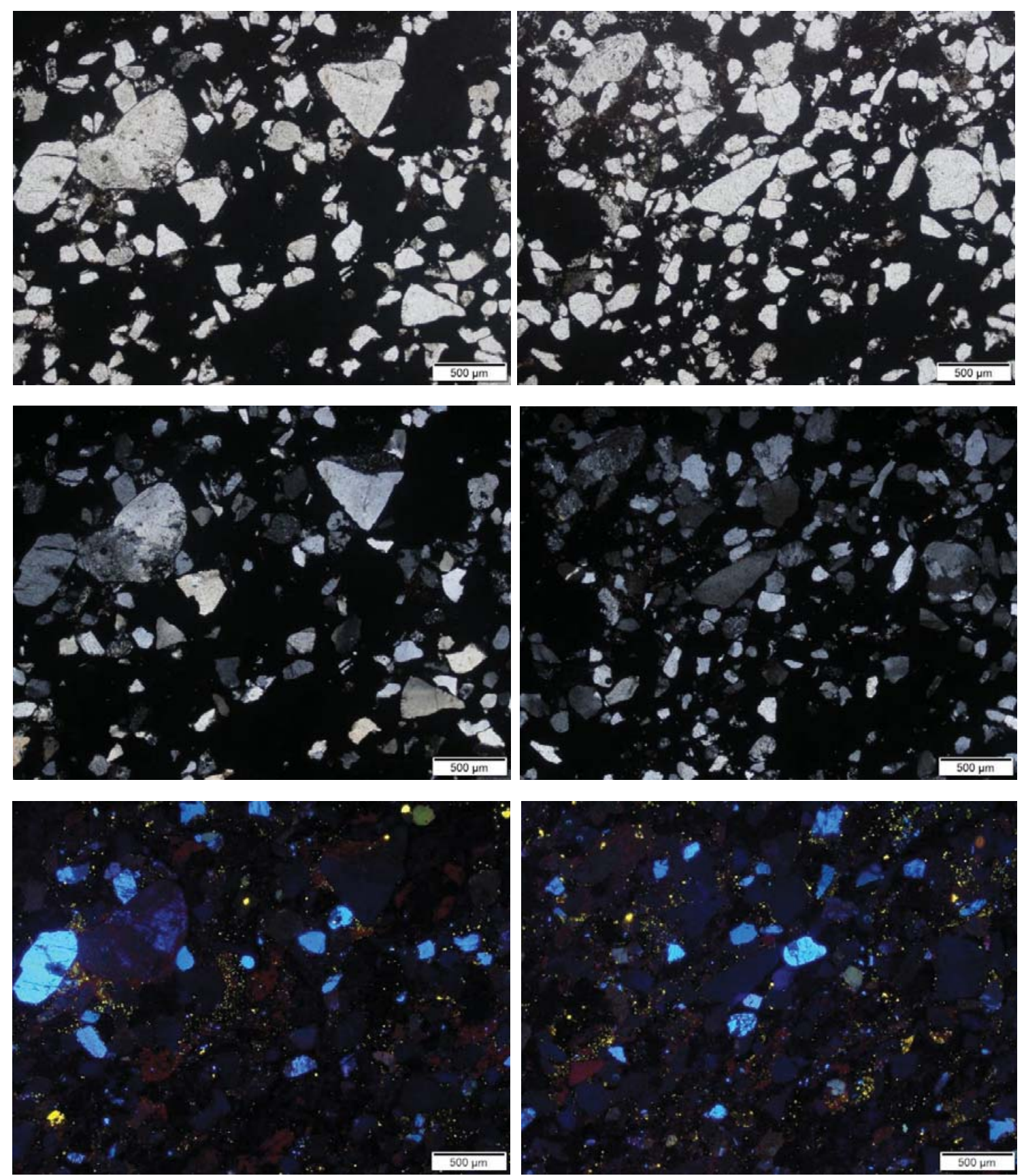

yellow (apatite) grains follow biomat texture

most of the grains looking like debris clasts are non luminescent. 


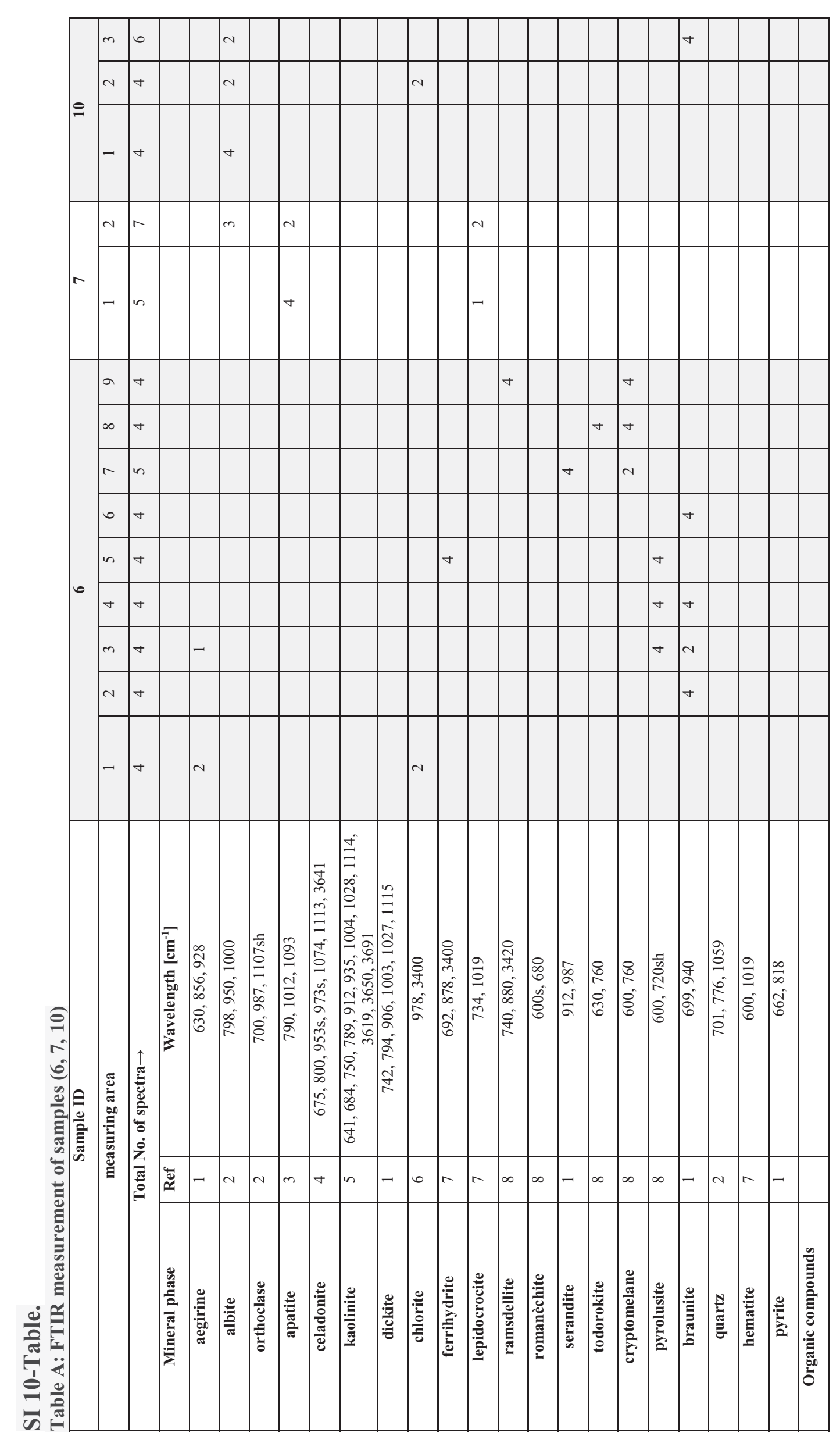




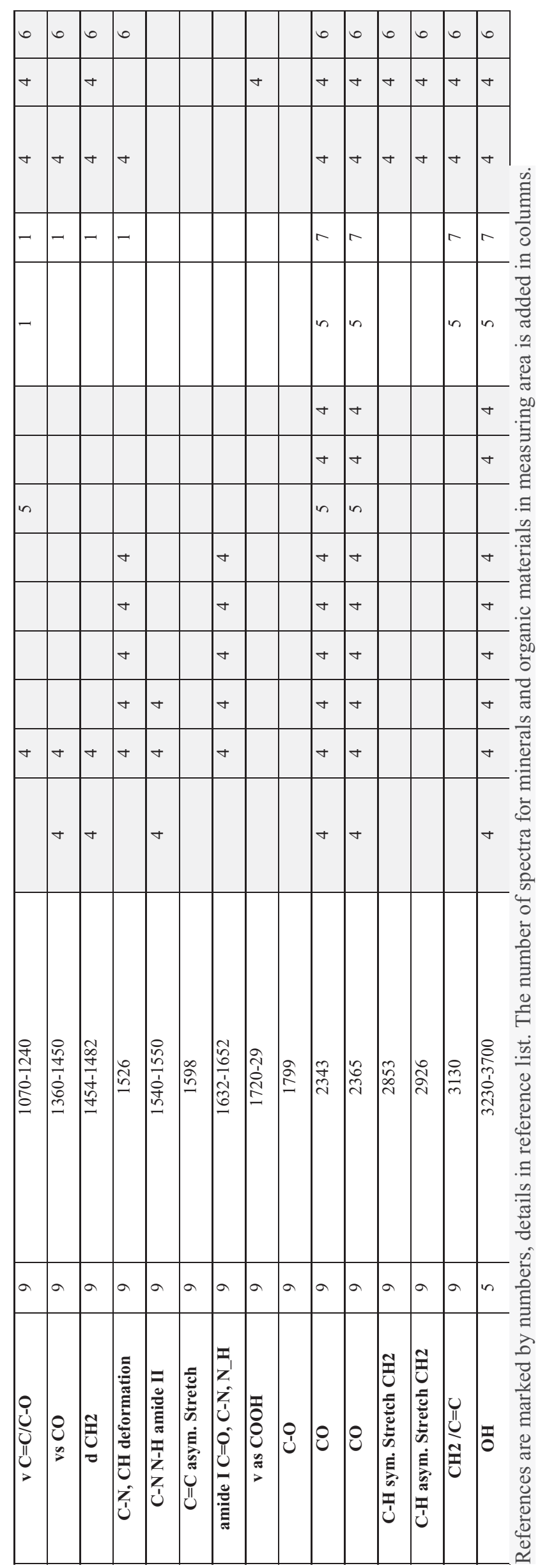




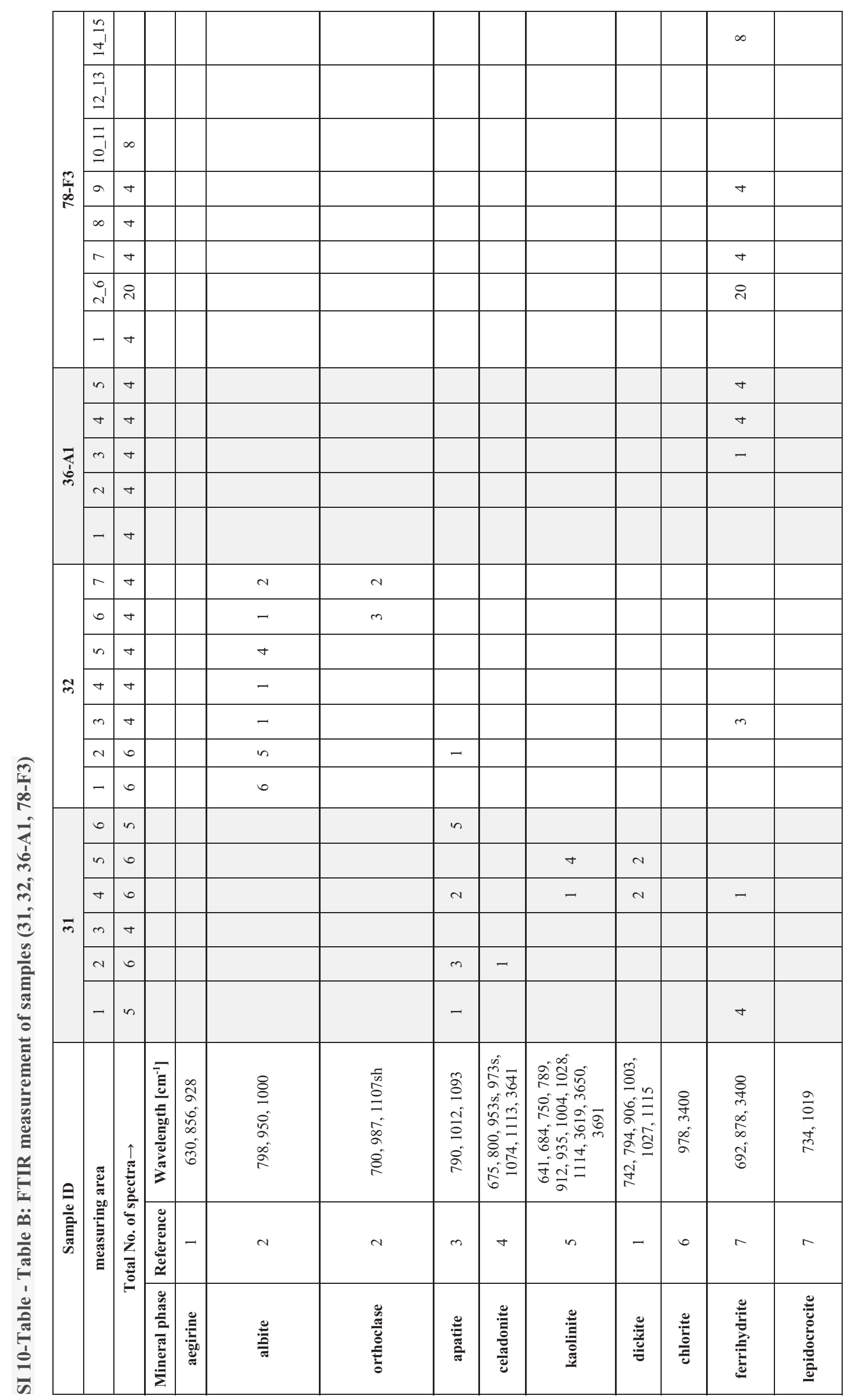




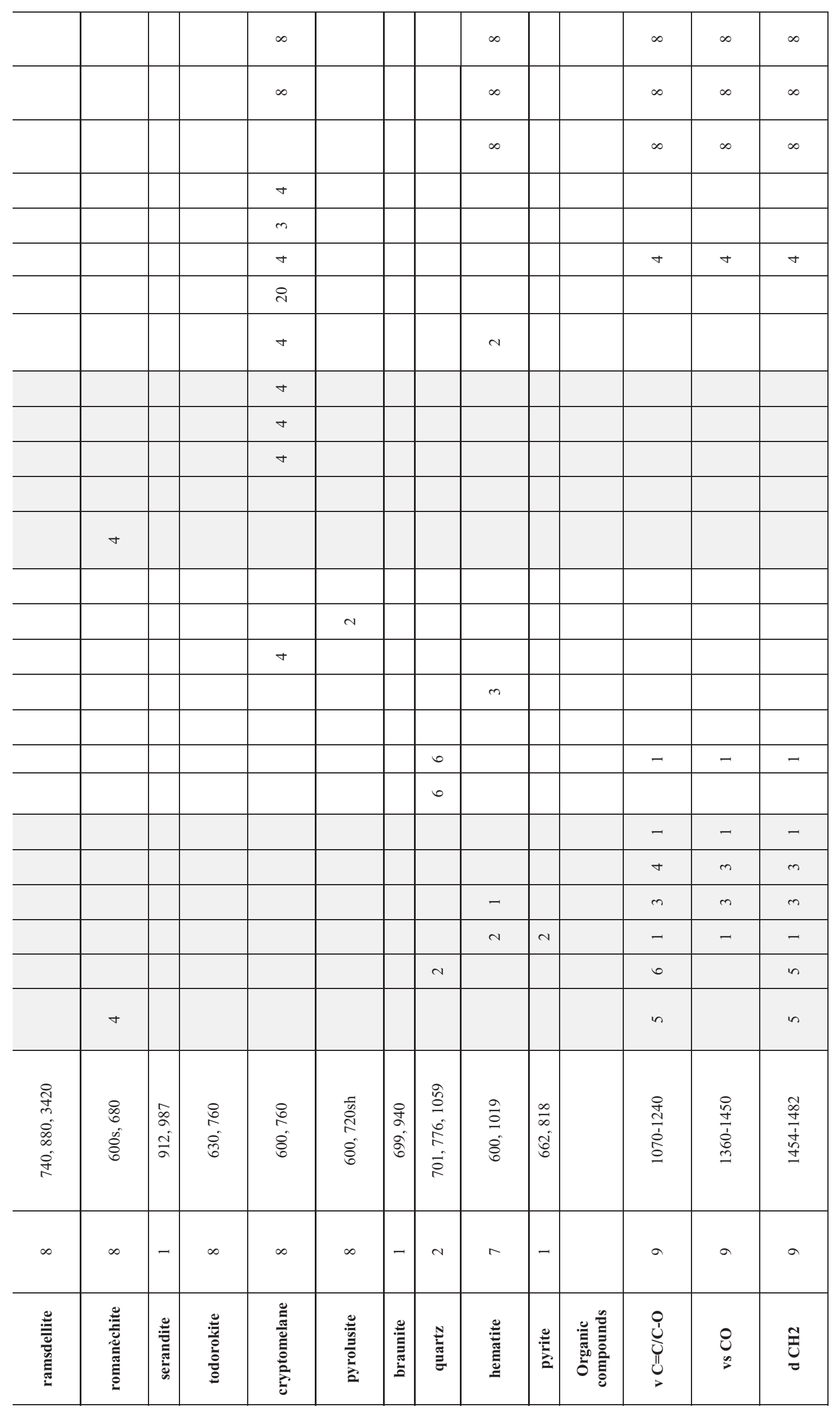




\begin{tabular}{|c|c|c|c|c|c|c|c|c|c|c|c|}
\hline$\infty$ & $\infty$ & & $\infty$ & $\infty$ & & $\infty$ & $\infty$ & & & & \\
\hline$\infty$ & $\infty$ & & $\infty$ & $\infty$ & & $\infty$ & $\infty$ & & & & \\
\hline$\infty$ & $\infty$ & & $\infty$ & $\infty$ & & $\infty$ & $\infty$ & & & $\infty$ & $\infty$ \\
\hline & & & & & & & & & & & \\
\hline & & & & & & & & & & & \\
\hline \multirow[t]{13}{*}{$\nabla$} & $\nabla$ & & $\checkmark$ & $\nabla$ & & $\checkmark$ & $\nabla$ & & & & \\
\hline & & & & & & $\stackrel{\text { i }}{\text { s. }}$ & $\stackrel{\sim}{ }$ & & & & \\
\hline & & & & & & 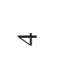 & r & & & & \\
\hline & & & & & & 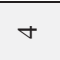 & + & & & & \\
\hline & & & & & & $\nabla$ & ナ & & & $\nabla$ & $\nabla$ \\
\hline & & & & & & $\checkmark$ & $\nabla$ & & & & \\
\hline & & & & & & $\nabla$ & $\nabla$ & & & & \\
\hline & & & & & & $\nabla$ & $\nabla$ & & & & \\
\hline & & & & & & $\checkmark$ & $\nabla$ & & & & \\
\hline & & & & & & $\checkmark$ & $\nabla$ & & & & \\
\hline & & & & & & ナ & $\nabla$ & & & & + \\
\hline & & & & & & $\checkmark$ & $\nabla$ & & & & \\
\hline & & & & & & $\checkmark$ & 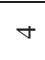 & & & & \\
\hline \multirow[t]{2}{*}{-} & & & & & & 0 & 0 & & - & - & \\
\hline & & & & & & 0 & 6 & & & & \\
\hline- & & - & & & & in & in & in & in & in & in \\
\hline$m$ & & & & & & 0 & 6 & & & 0 & 0 \\
\hline$m$ & & & & & & 0 & 0 & & & 0 & 0 \\
\hline- & & & & & & $\nabla$ & $\nabla$ & & & $\sigma$ & 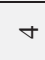 \\
\hline in & & & & & & 0 & 6 & 0 & 0 & 6 & 6 \\
\hline in & & & & & & in & in & in & in & & \\
\hline$\stackrel{\widetilde{N}}{\sim}$ & 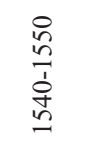 & $\begin{array}{l}\infty \\
\text { in }\end{array}$ & 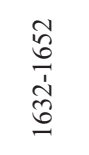 & ते & 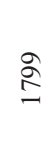 & 尔 & 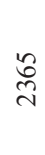 & $\begin{array}{l}\hat{\hat{\infty}} \\
\stackrel{\sim}{N}\end{array}$ & ๙ั & $\frac{m}{m}$ & $\begin{array}{l}\stackrel{8}{0} \\
\text { o. } \\
\text { లై }\end{array}$ \\
\hline$a$ & $a$ & $a$ & $a$ & $a$ & $a$ & $a$ & $a$ & $a$ & $a$ & $a$ & in \\
\hline 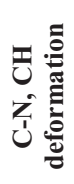 & 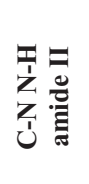 & 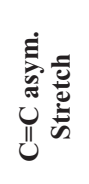 & 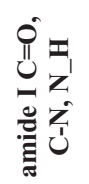 & 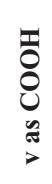 & ن̊ & 8 & 8 & 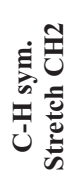 & 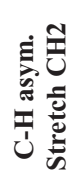 & 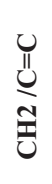 & ఫี \\
\hline
\end{tabular}




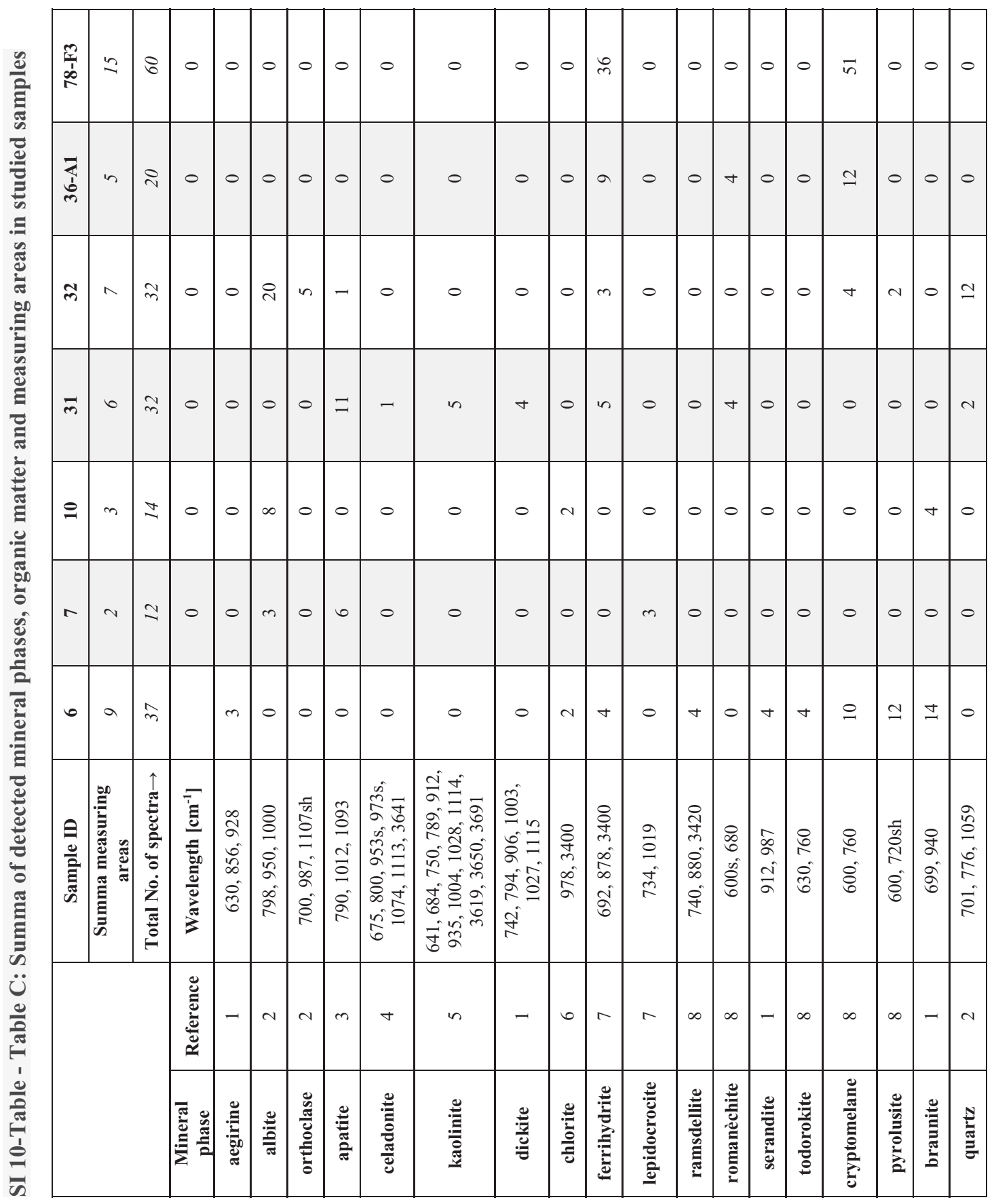




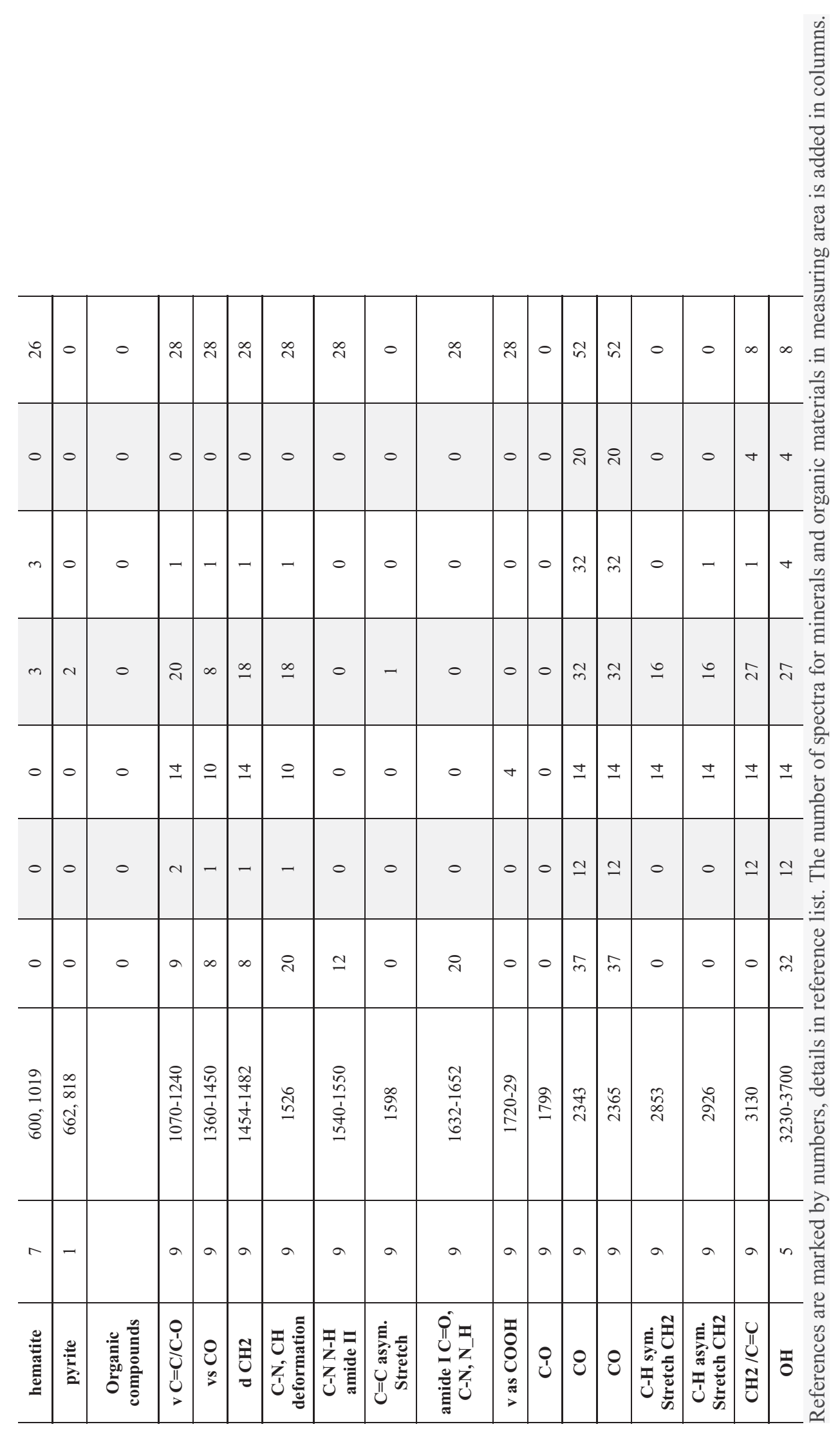




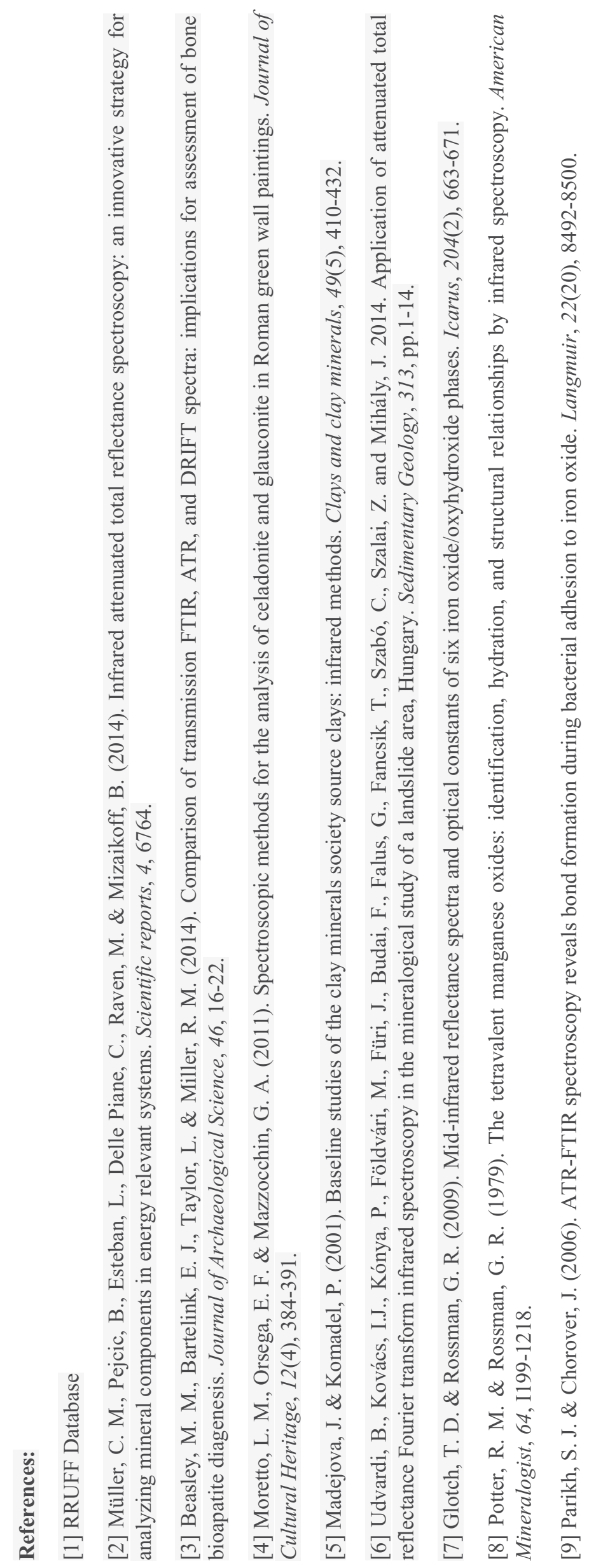




\section{SI 11-Fig. Interpretation of mineral composition and distribution of spherical (bubble-like) structure of sample 36-A based on FTIR}

\section{Outer area}

This area is inhomogeneous, consist of dark spots and bright inhomogenous area.

\section{Matrix}

This inhomogenic matrix area was investigated in „outer area 1" This part is mixed by goethite, feldspar, disordered rhodochrosite, traces of cryptomelane. The organic material contains immaturated hydrocarbons - CH-CCN bonds of amid I-amid II (1520-1660 $\mathrm{cm}^{-}$ $\left.{ }^{1}\right)$.

\section{Dark spots}

This parts contain ferrihydrite (with traces of goethite), disordered rhodochrosite, traces of cryptomelane, organic material and maturated, long-chain hydrocarbon (bands 2900$\left.3100 \mathrm{~cm}^{-1}\right)$, and ketons $(\mathrm{C}=\mathrm{O})$

\section{Rim area}

This is inhomogenous, composed of a fine-grained area, and coarser crystallized area. The coarser area is mixture of cryptomelane and broad bands of disordered quartz, rhodochrosite and dolomite, and traces of braunite. The dolomite has CO3 vibration at $1425 \mathrm{~cm}^{-1}$, the rhodocrosite has near $1390 \mathrm{~cm}^{-1}$. This area contains variable organic material, which contain long chain hydrocarbons ( $\mathrm{CH} 2$ symmetric and asymmetric stretching modes $\left.2853-3130 \mathrm{~cm}^{-1}\right)$, and C-O vibration of ketons $\left(2343-2365 \mathrm{~cm}^{-1}\right)$

The fine-grained porous part is composed of ferrihydrite, traces of goethite. This area contain bands of C-O vibration of ketons at 2343 and $2365 \mathrm{~cm}^{-1}$.

\section{Inner area}

It was measured by 3 FTIR area (inner area 1-3).

\section{Matrix}

The inhomogeneous matrix, which composed of porous, laminated parts, which was measured by lighter part, darker part, and average inhomogeneous part:

The lighter part (area2) is mixture of cryptomelane, quartz, and dolomite, and organic material with $\mathrm{CH} 2$ bonds $\left(1452-1482 \mathrm{~cm}^{-1}\right)$ and ketons $(\mathrm{C}=\mathrm{O})$.

Inhomogenous matrix (area1) dark parts contains dolomite, ferrihydrite, cryptomelane.

Porous inhomogenous matrix (area2) is also mixed material, which contain cyptomelane, ferrihydrite, dolomite (traces) and organic material with $\mathrm{CH} 2$ bonds $\left(1452-1482 \mathrm{~cm}^{-1}\right)$ and ketons $(\mathrm{C}=\mathrm{O})$.

\section{Dark spot}

The inner area 3 focused on dark spots, which are composed of mixture of ramsdellite, quartz and dolomite, and contains organic material of long-chain hydrocarbons (2900$3100 \mathrm{~cm}^{-1}$ ), ketons, and $\mathrm{CN}-\mathrm{CH}$ bonds of PAHs. 
36-A FTIR vibrations

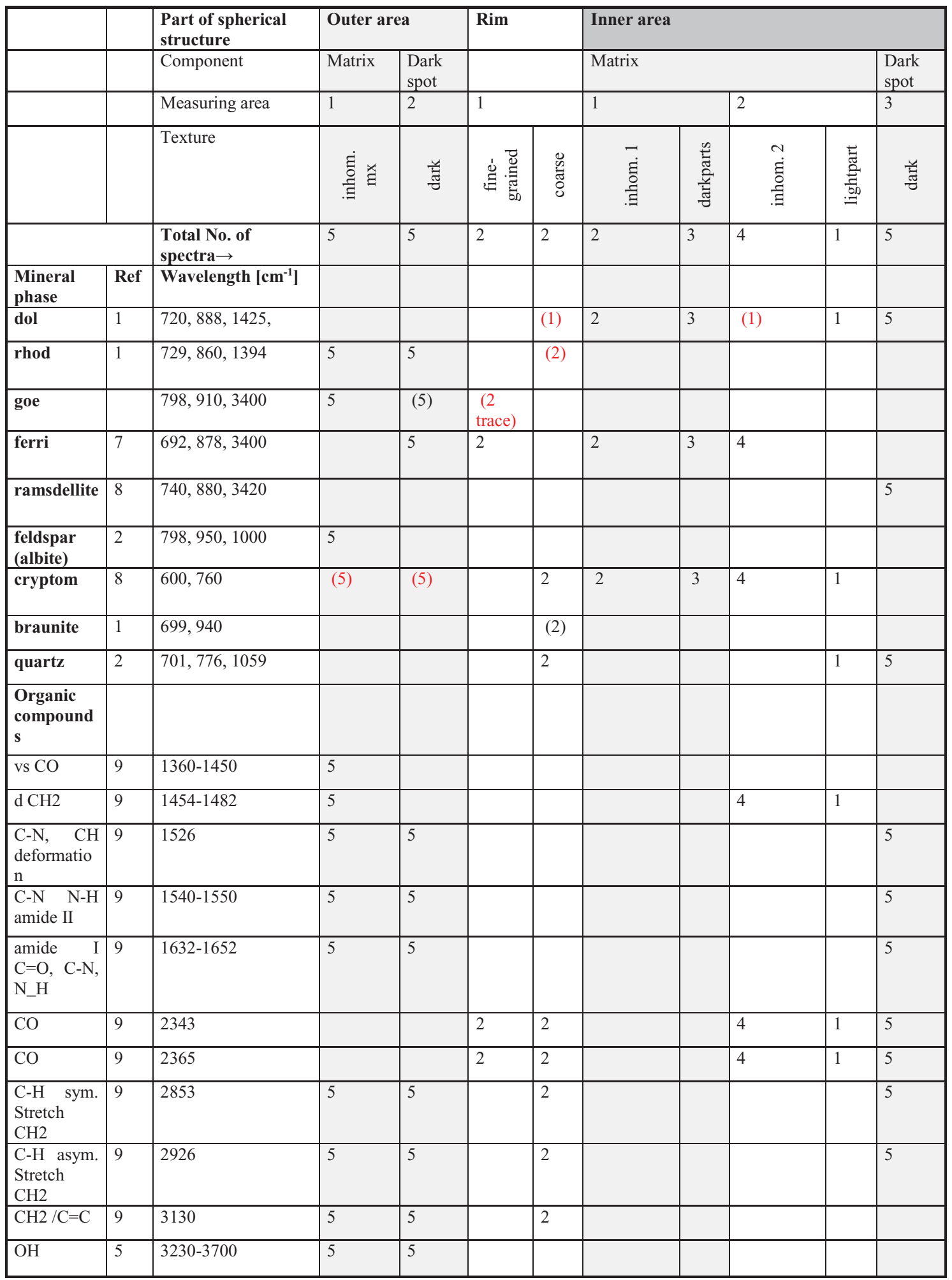

Summary table of mineral phases (References see in SI 10-Table).

\begin{tabular}{|c|c|c|c|c|c|c|c|c|}
\hline \multicolumn{2}{|c|}{ Outer area } & \multicolumn{2}{|c|}{ Rim } & \multicolumn{5}{|c|}{ Inner area } \\
\hline $\begin{array}{l}\text { inhom. } \\
\text { matrix }\end{array}$ & dark spot & coarse & $\begin{array}{l}\text { fine- } \\
\text { grained }\end{array}$ & $\begin{array}{l}\text { inhom. } \\
\text { matrix1 }\end{array}$ & $\begin{array}{l}\text { inhom. } \\
\text { matrix2 }\end{array}$ & dark part & $\begin{array}{l}\text { light } \\
\text { part }\end{array}$ & dark spot \\
\hline $\begin{array}{l}\text { goe } \\
\text { feldsp } \\
\text { rhod } \\
\text { cryptom }\end{array}$ & $\begin{array}{l}\text { ferri } \\
\text { goe } \\
\text { rhod } \\
\text { cryptom }\end{array}$ & $\begin{array}{l}\text { cryptom } \\
\text { quartz } \\
\text { rhod } \\
\text { dol } \\
\text { brau }\end{array}$ & $\begin{array}{l}\text { ferri } \\
\text { goe }\end{array}$ & $\begin{array}{l}\text { ferri } \\
\text { cryptom } \\
\text { dol }\end{array}$ & $\begin{array}{l}\text { ferri } \\
\text { cryptom } \\
\text { dol }\end{array}$ & $\begin{array}{l}\text { ferri } \\
\text { cryptom } \\
\text { dol }\end{array}$ & $\begin{array}{l}\text { cryptom } \\
\text { quartz } \\
\text { dol }\end{array}$ & $\begin{array}{l}\text { ramsdellite } \\
\text { quartz } \\
\text { dol }\end{array}$ \\
\hline
\end{tabular}

Abbrev: goe-goethite, ferri-ferrihydrite, feldsp-feldspar, rhod-rhodochrosite, cryptom-cryptomelane, dol-dolomite, brau-braunite 
36-A - Microtexture of spherical (bubble-like) structure,OM, reflective mode, arrows show mineralized microbial signatures and diffusion channels.
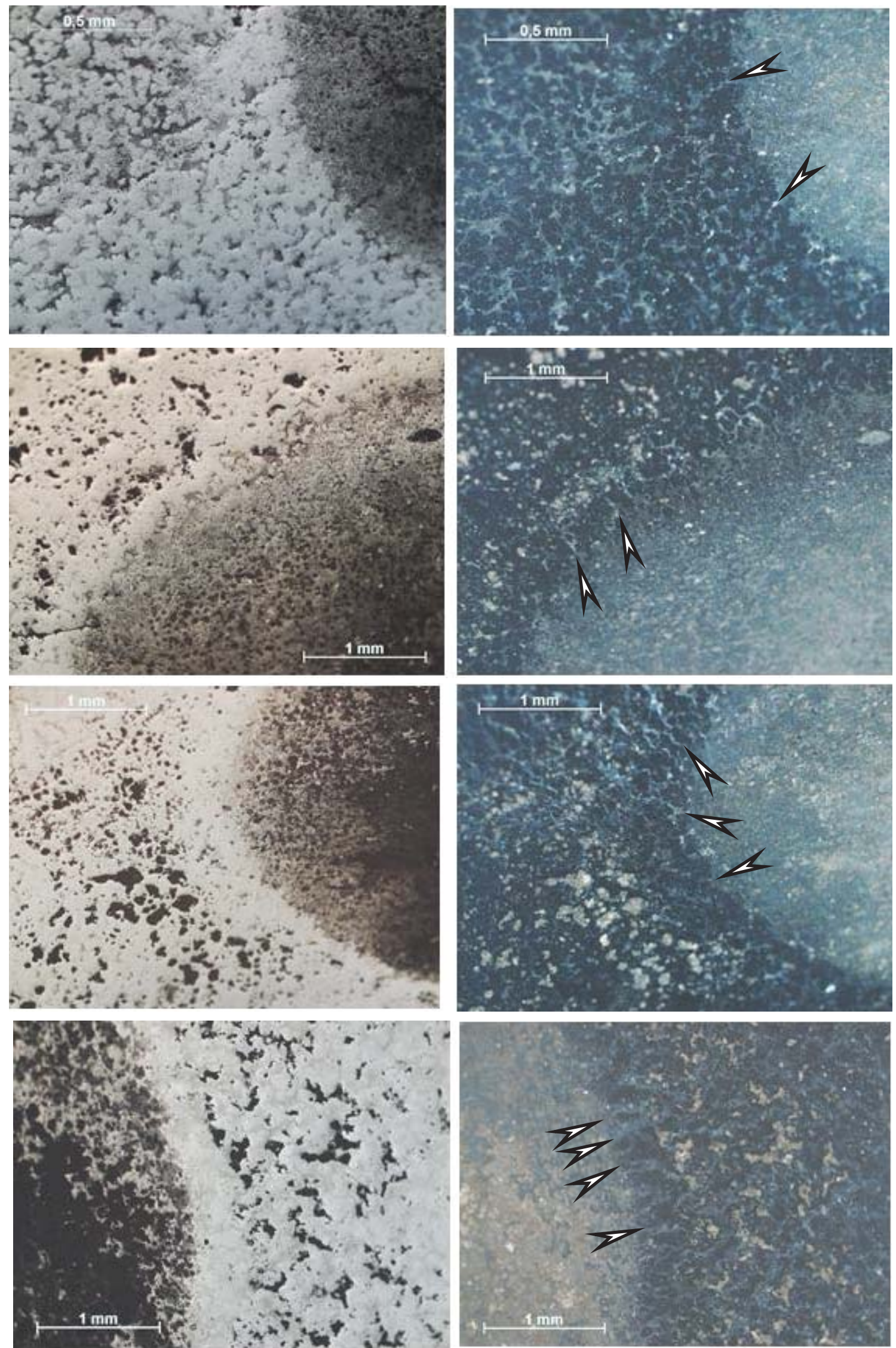
SI 12-Fig. Mineral distribution in profiles by Raman spectroscopy

Abbrev: Plg+Kfs-plagioclase $+\mathrm{F}-$ feldspar; $\mathrm{CM}$-carbonaceous material (organic matter)

4B (Mn-1)
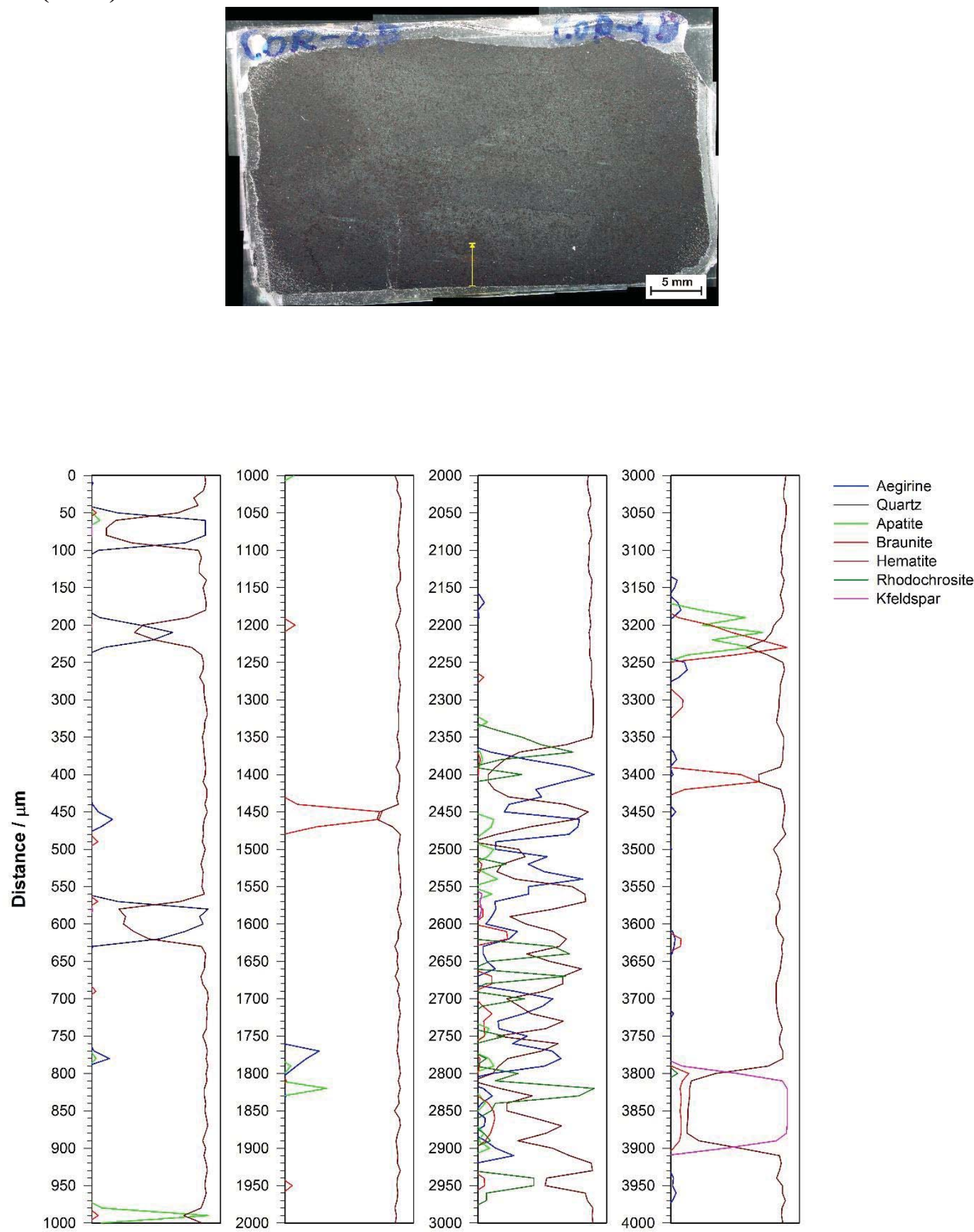

Normalized intensity / arbitrary unit 
10 (Mn-1)
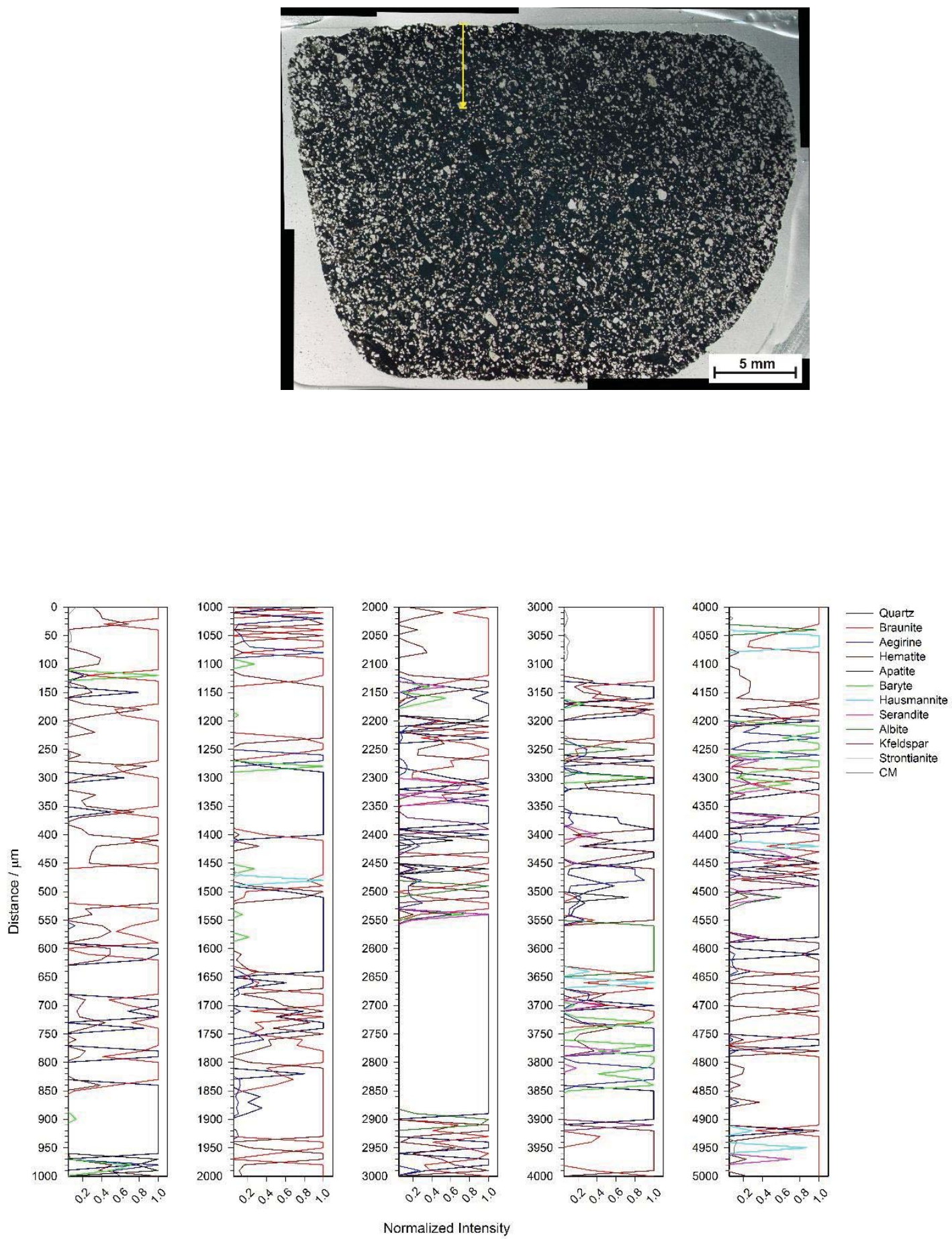
31 (Mn-1)
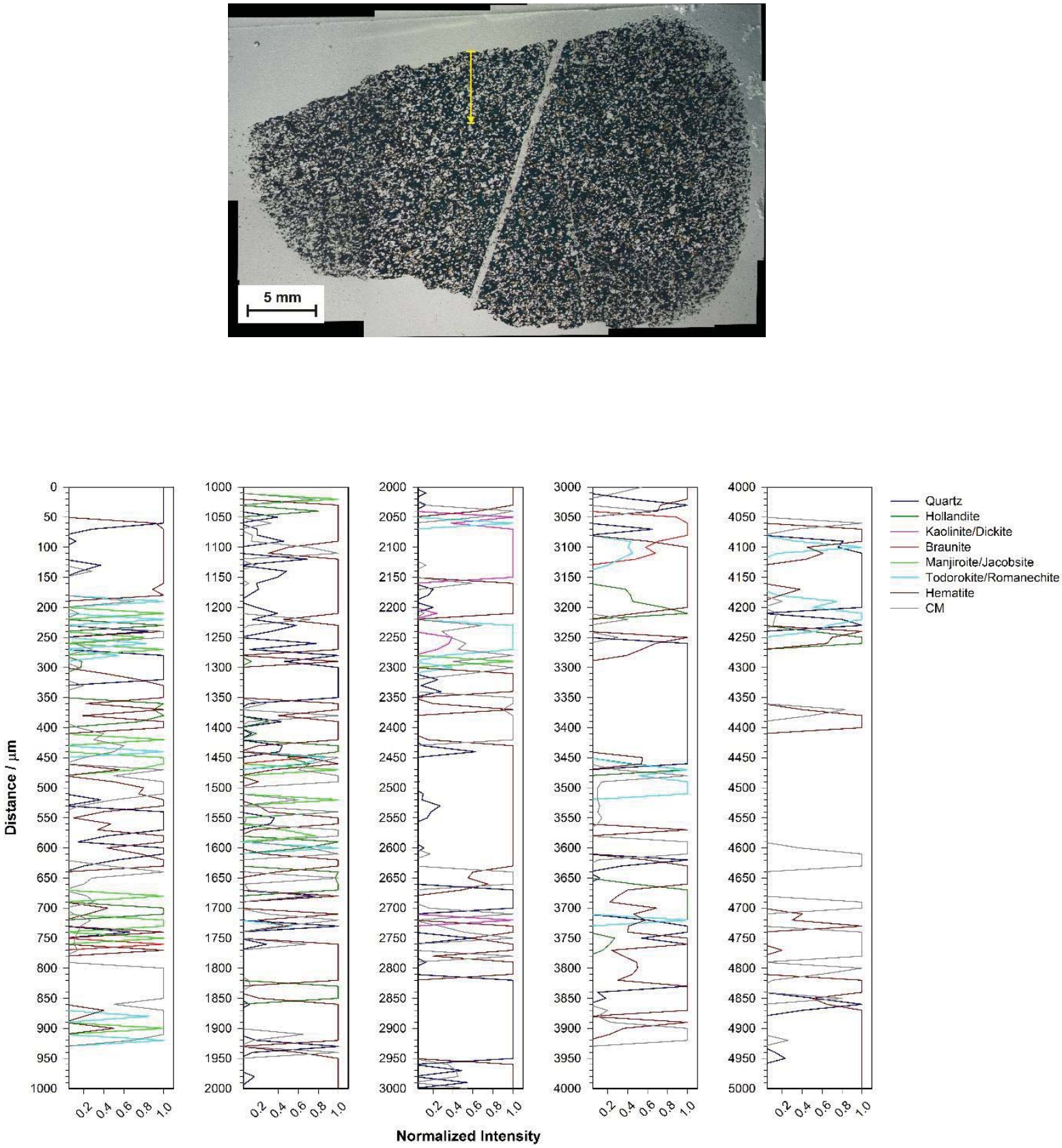

Normalized Intensity 
75-2 (Mn-2)
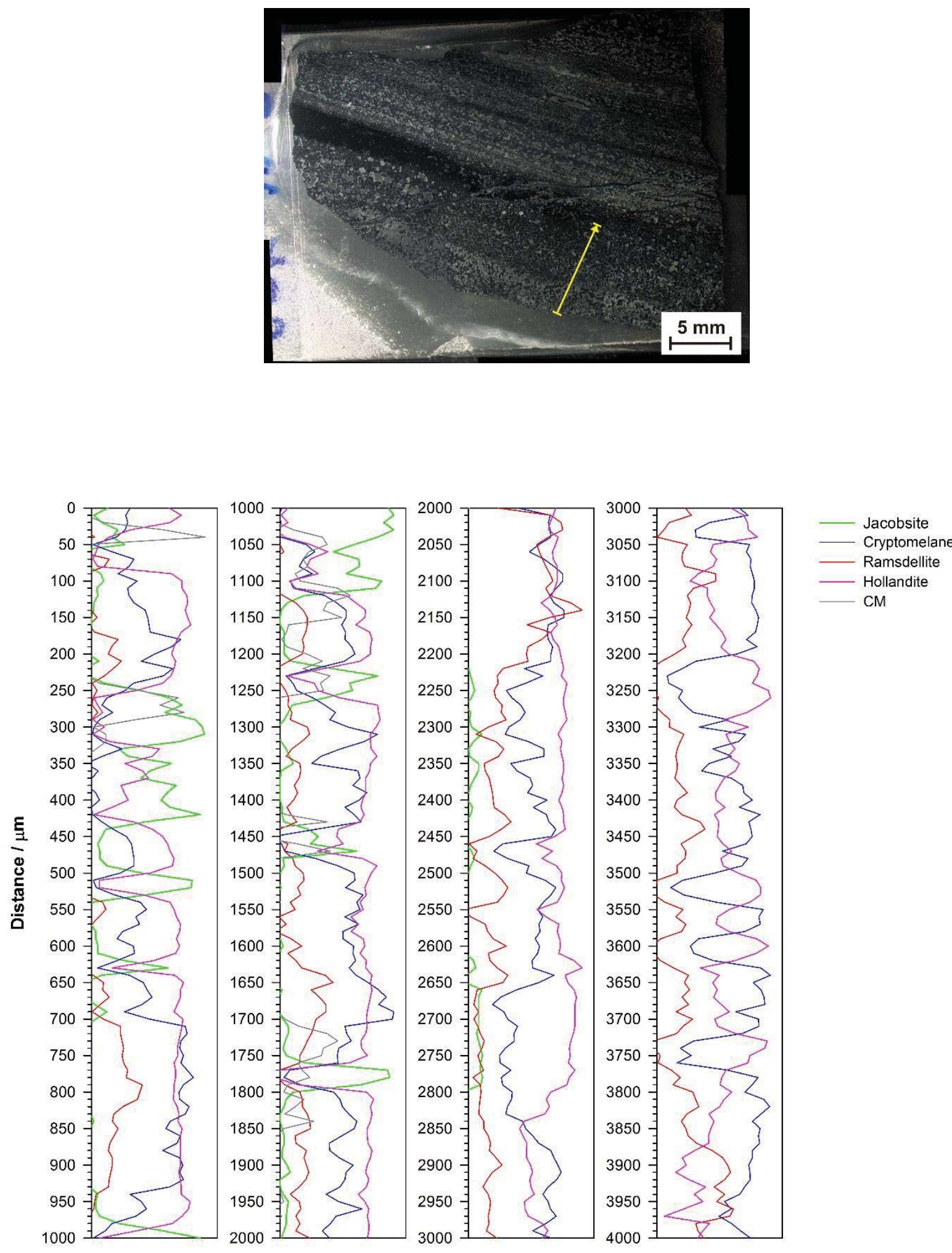

Normalized intensity / arbitrary unit 

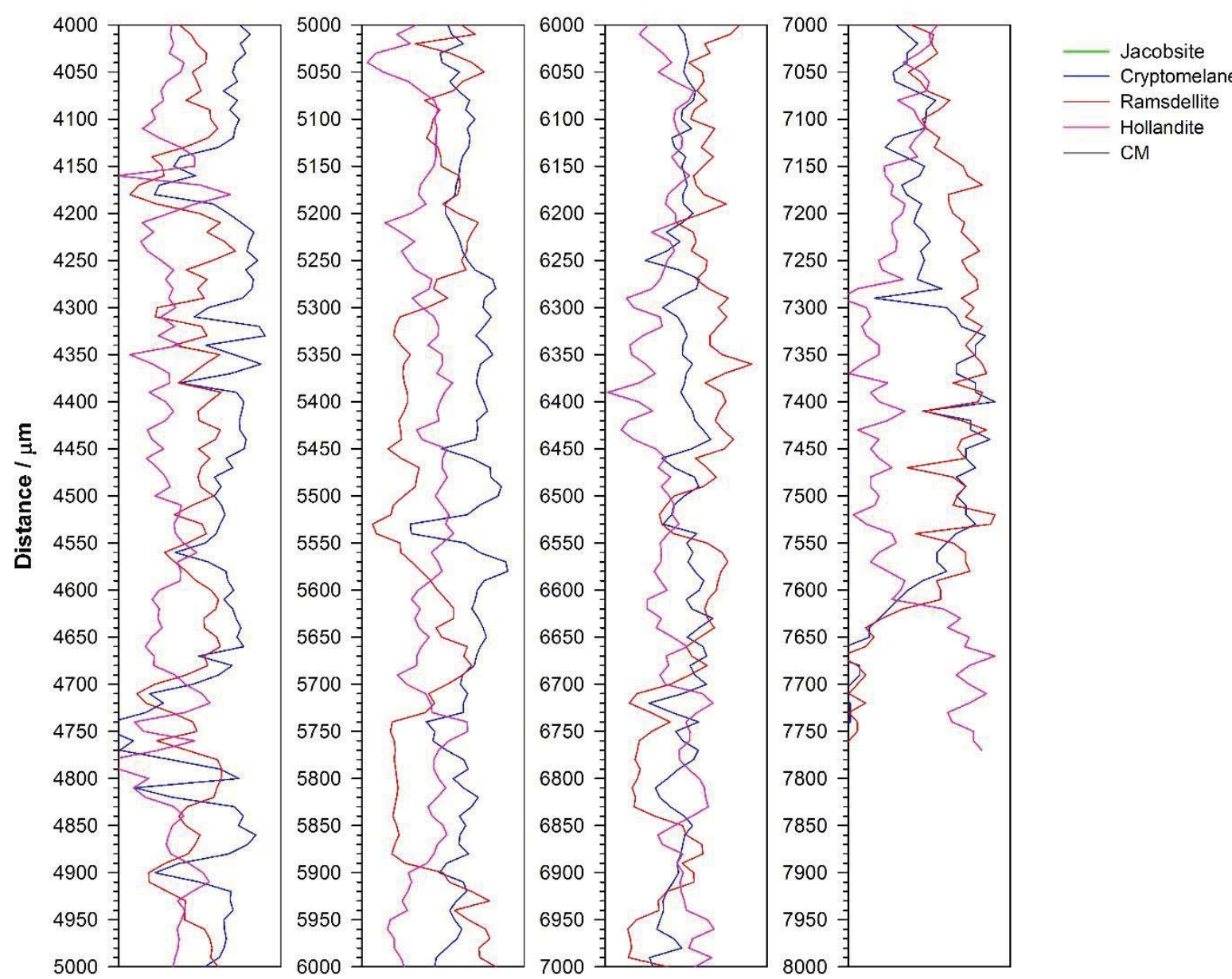

Normalized intensity / arbitrary unit 
75-B5 (Mn-2)
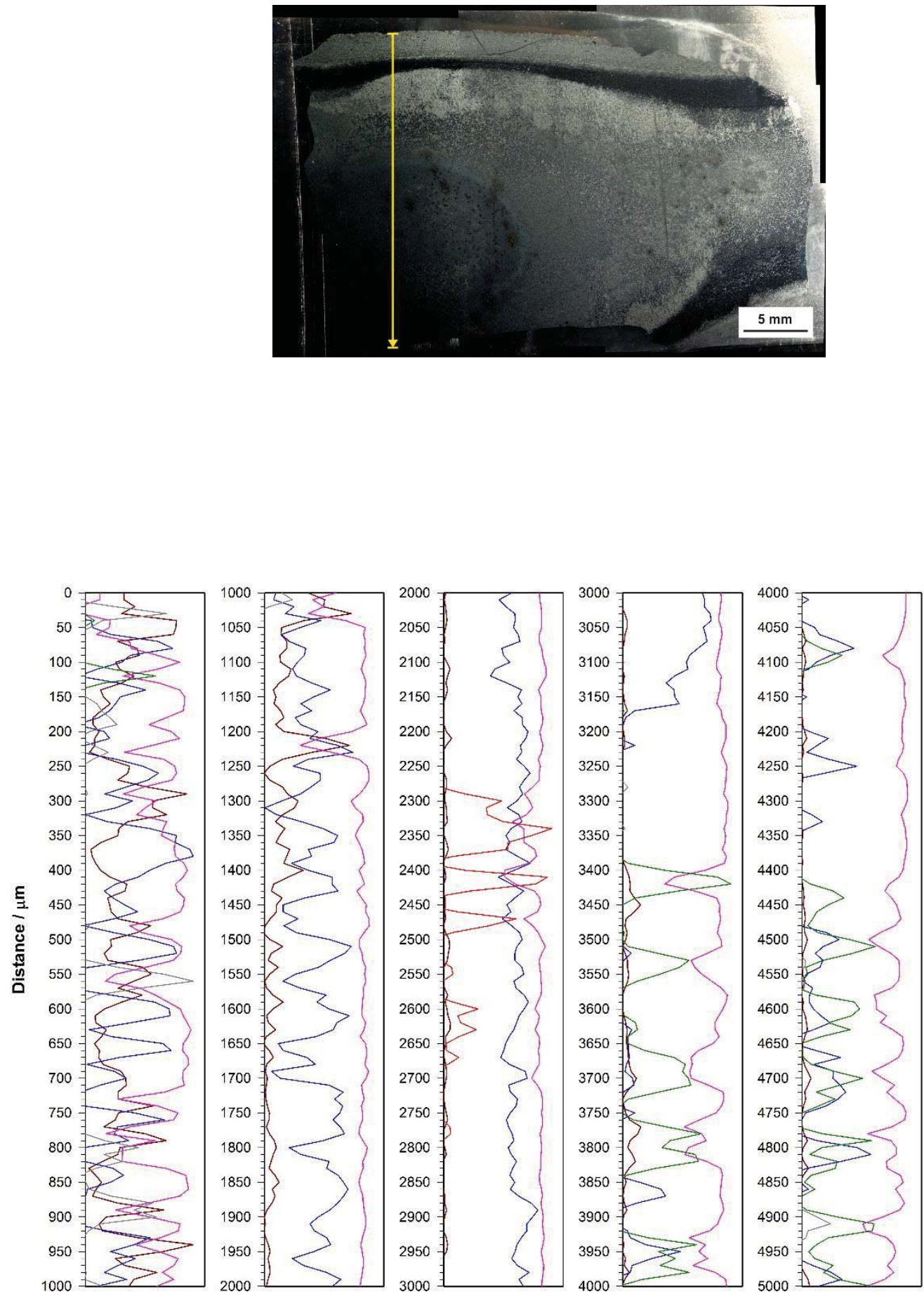

_- Hematite

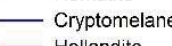

ormalized intensity / arbitrary unit 

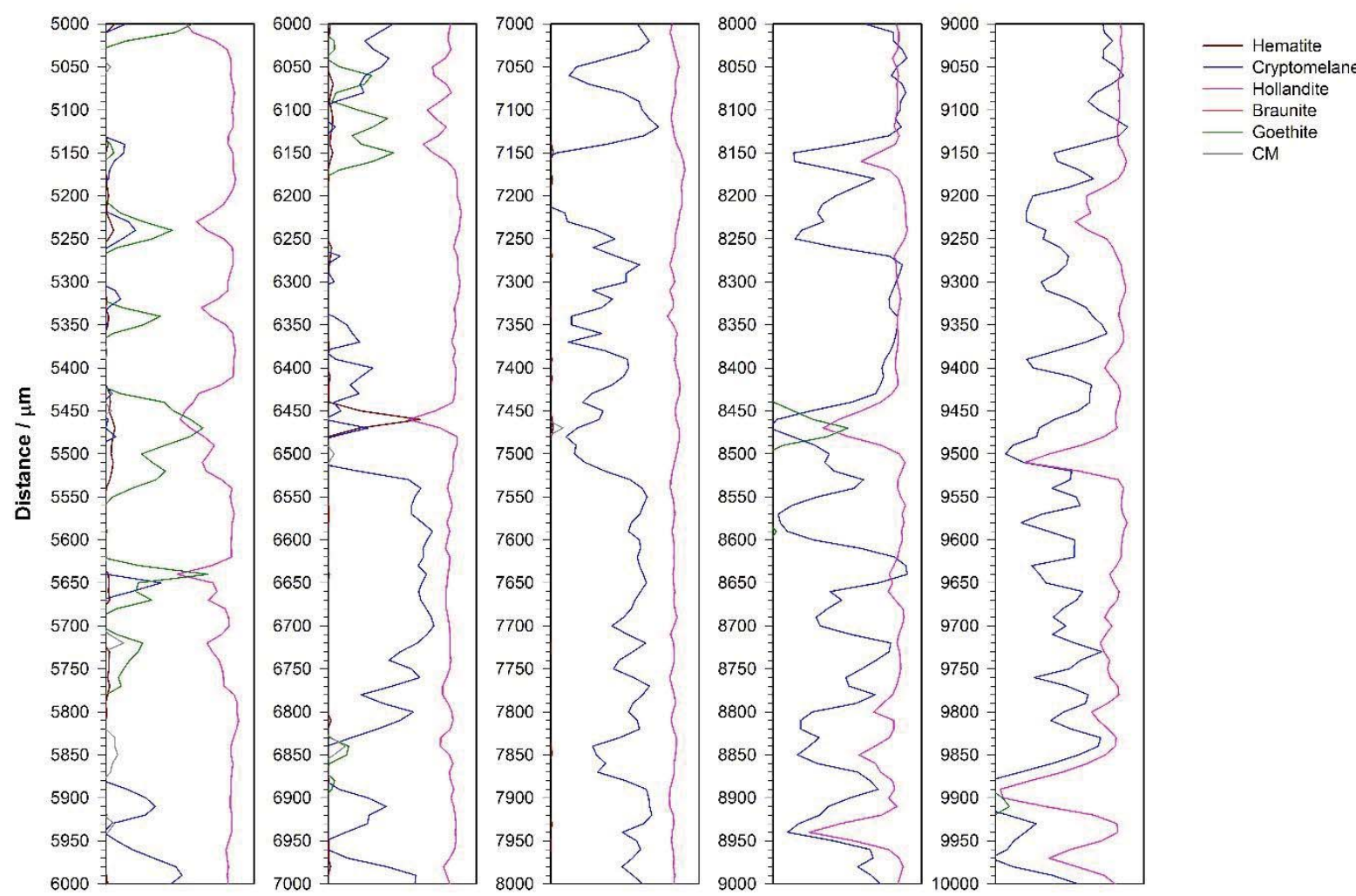

Normalized intensity / arbitrary unit
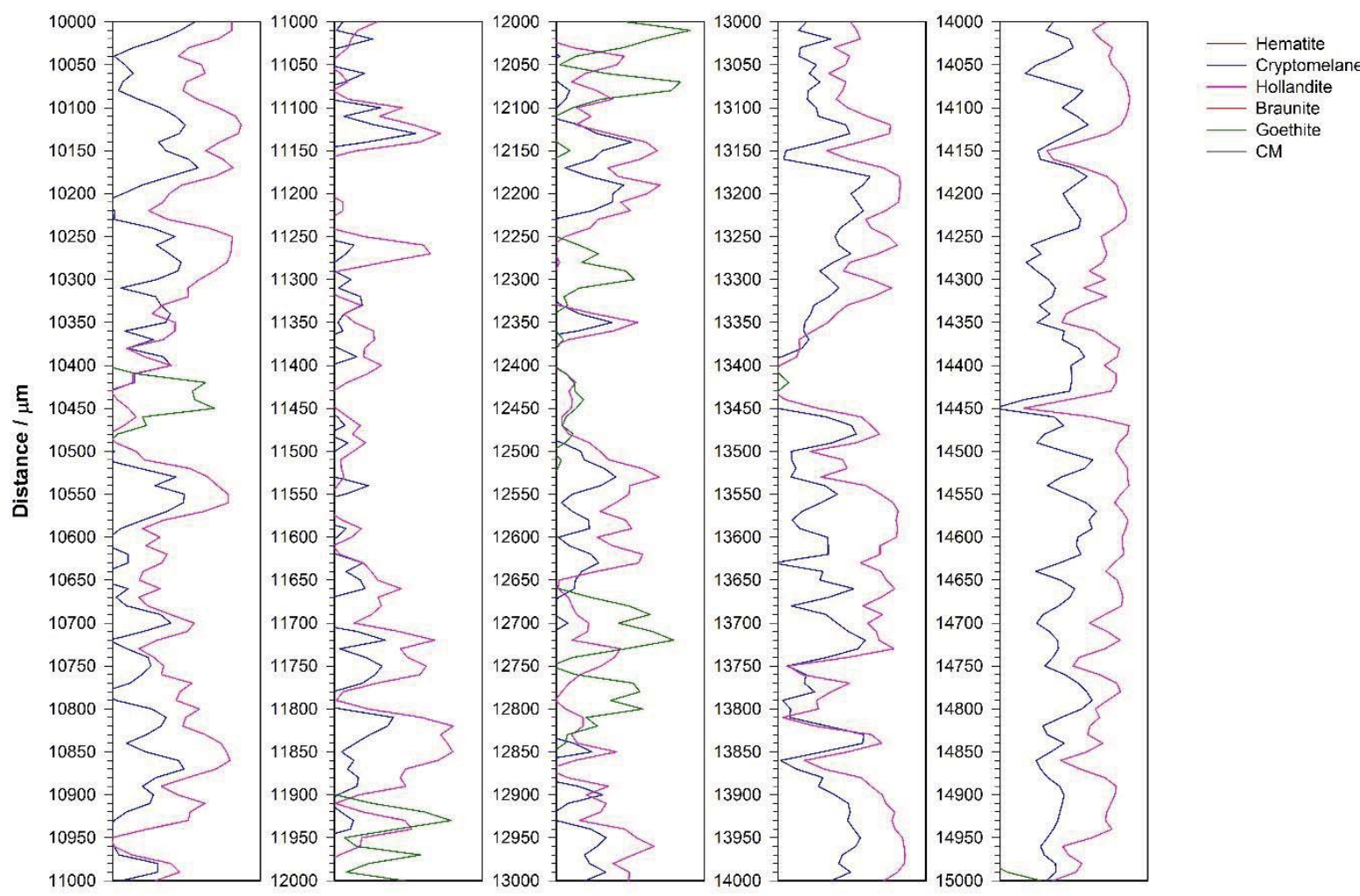

Normalized intensity / arbitrary unit 

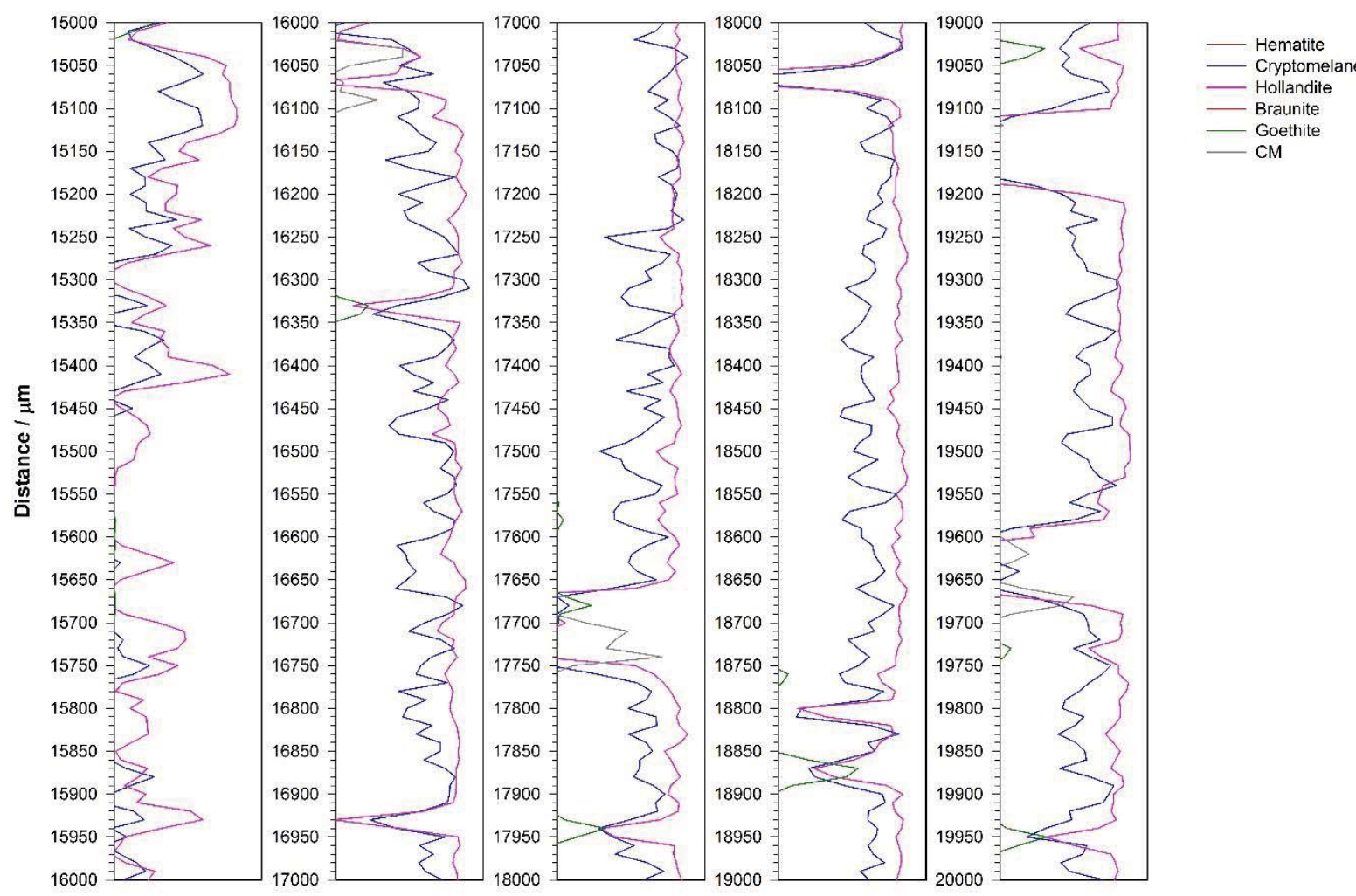

Normalized intensity / arbitrary unit 
78-D1 (Mn-2)
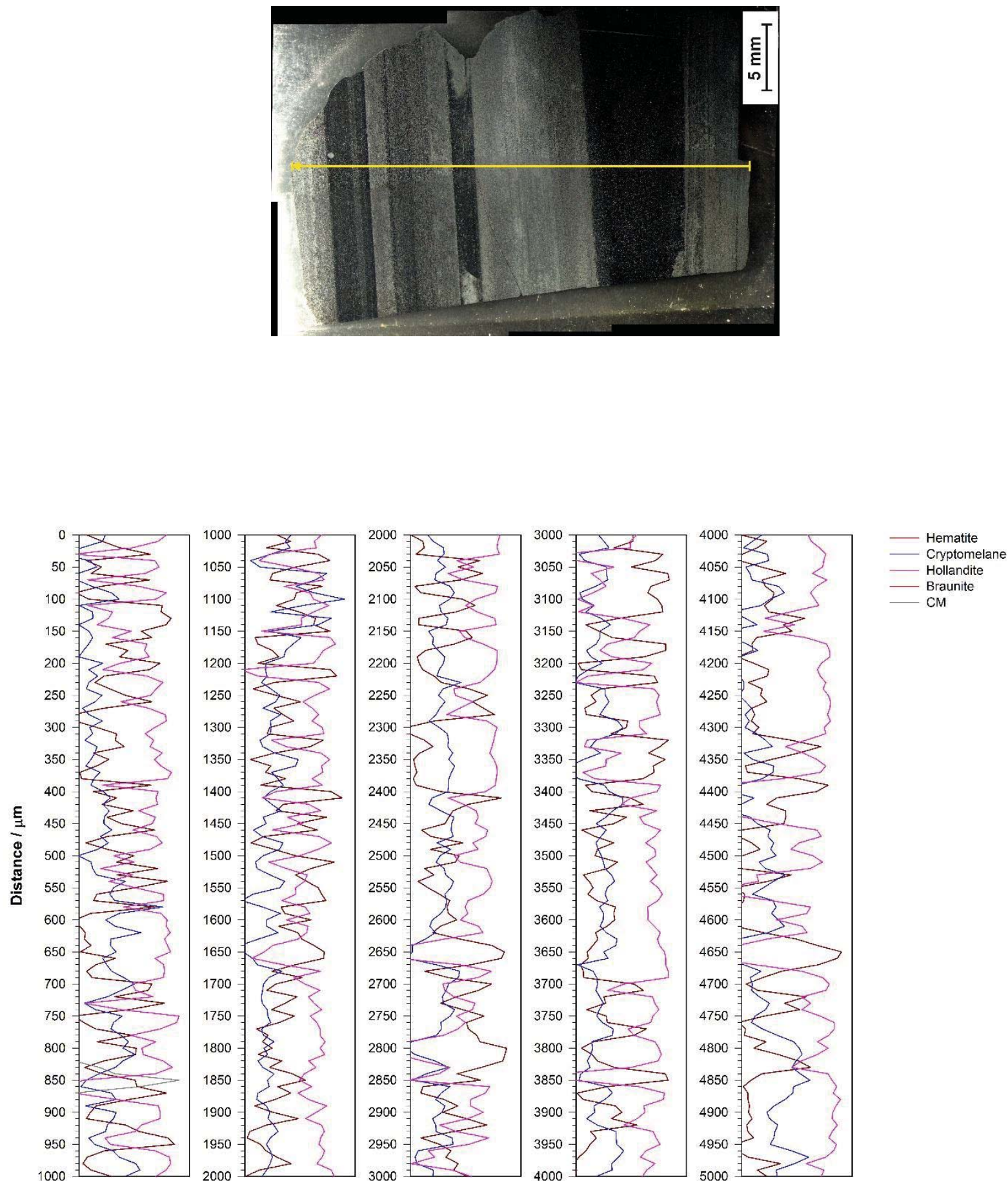

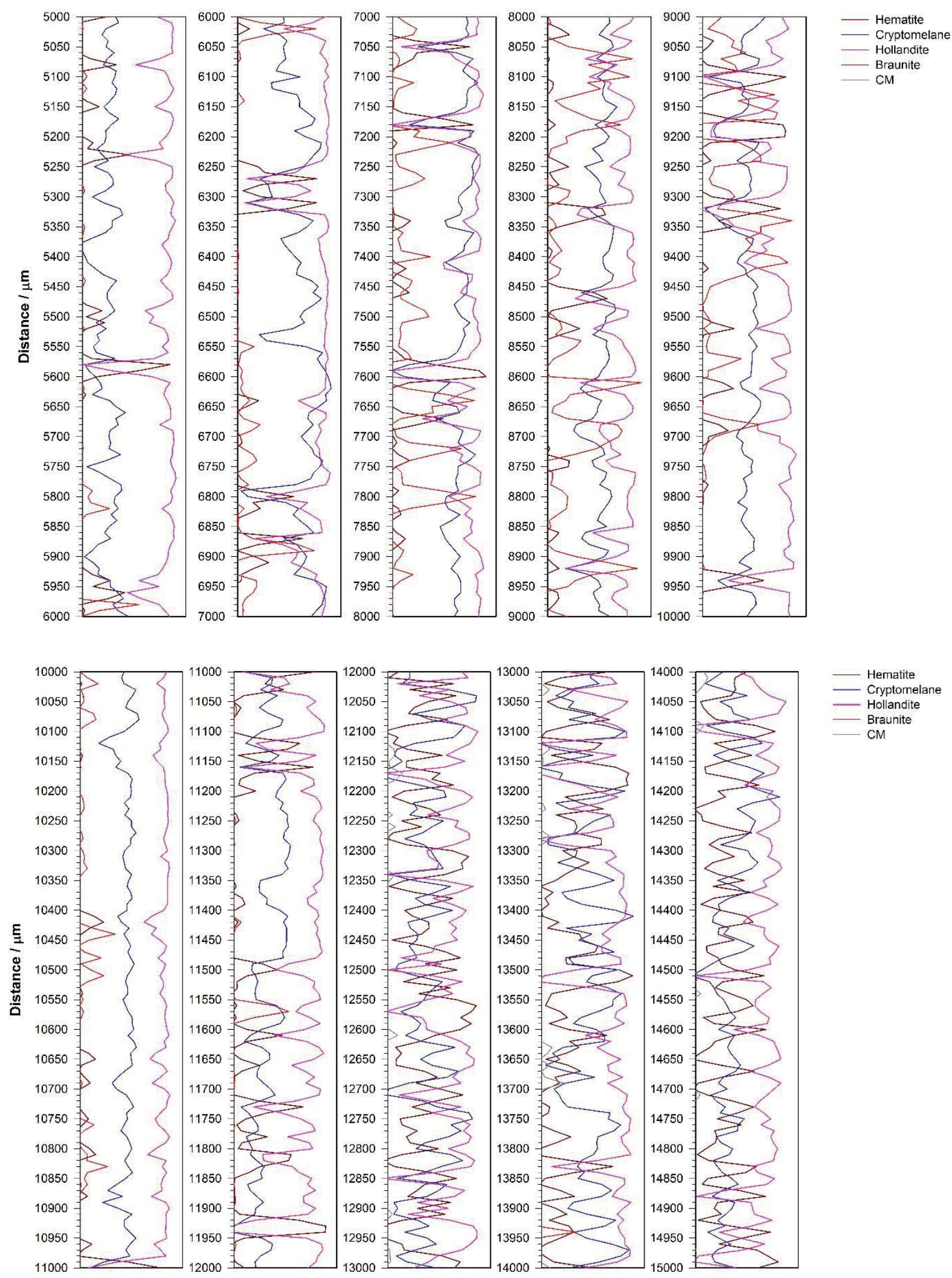

Normalized intensity / arbitrary unit 

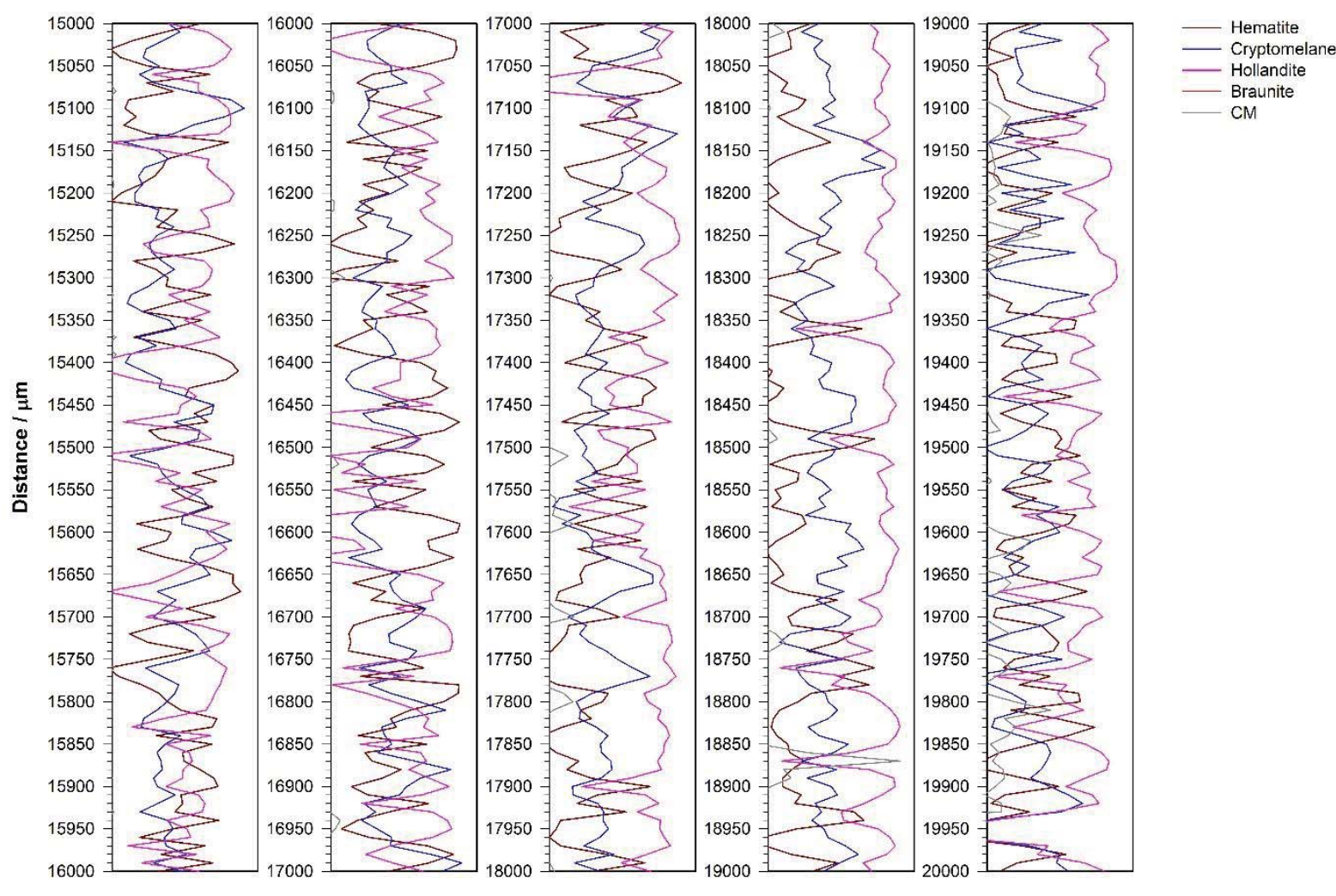

Hollandite

- Braunite
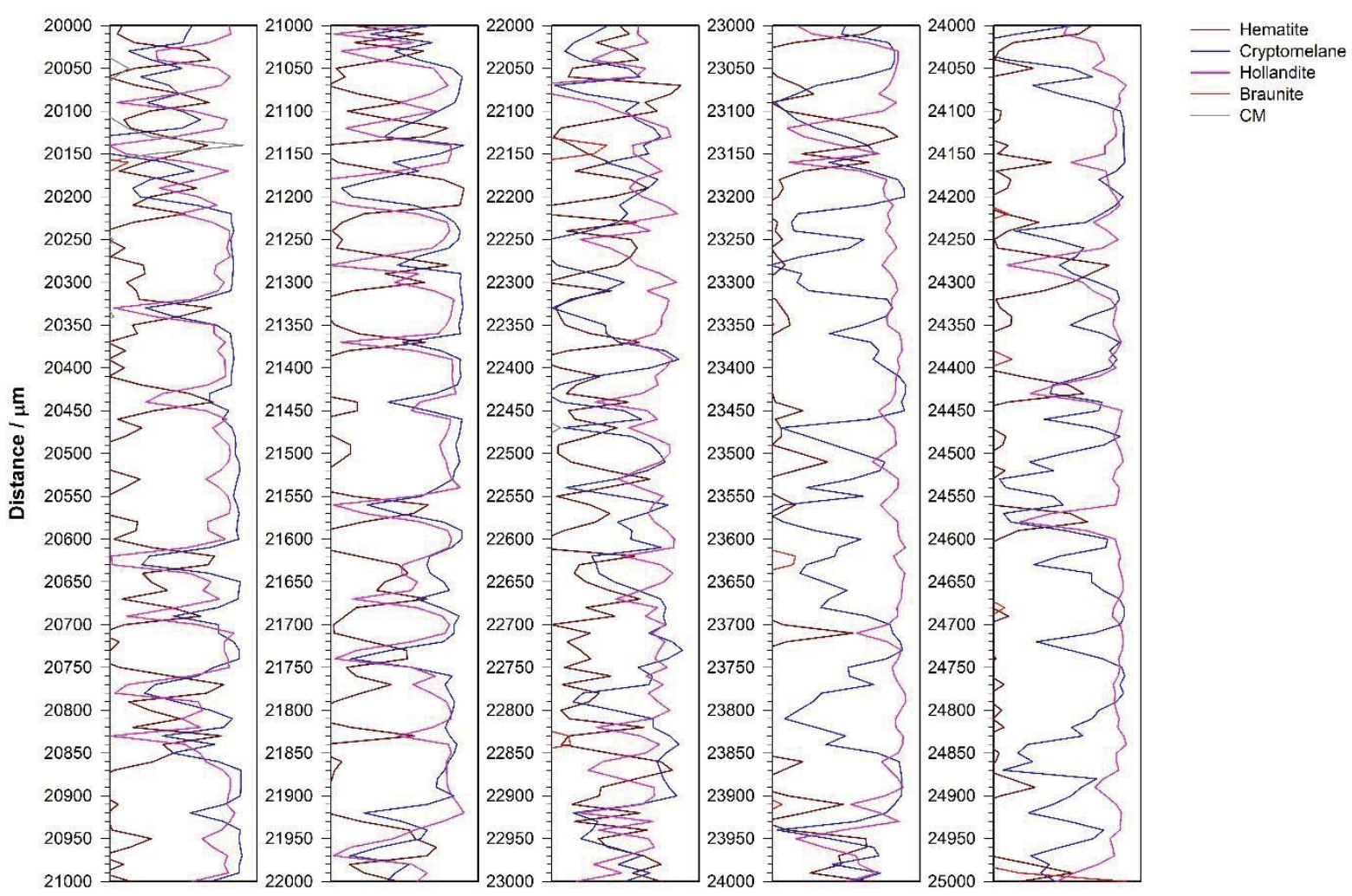

Normalized intensity / arbitrary unit 

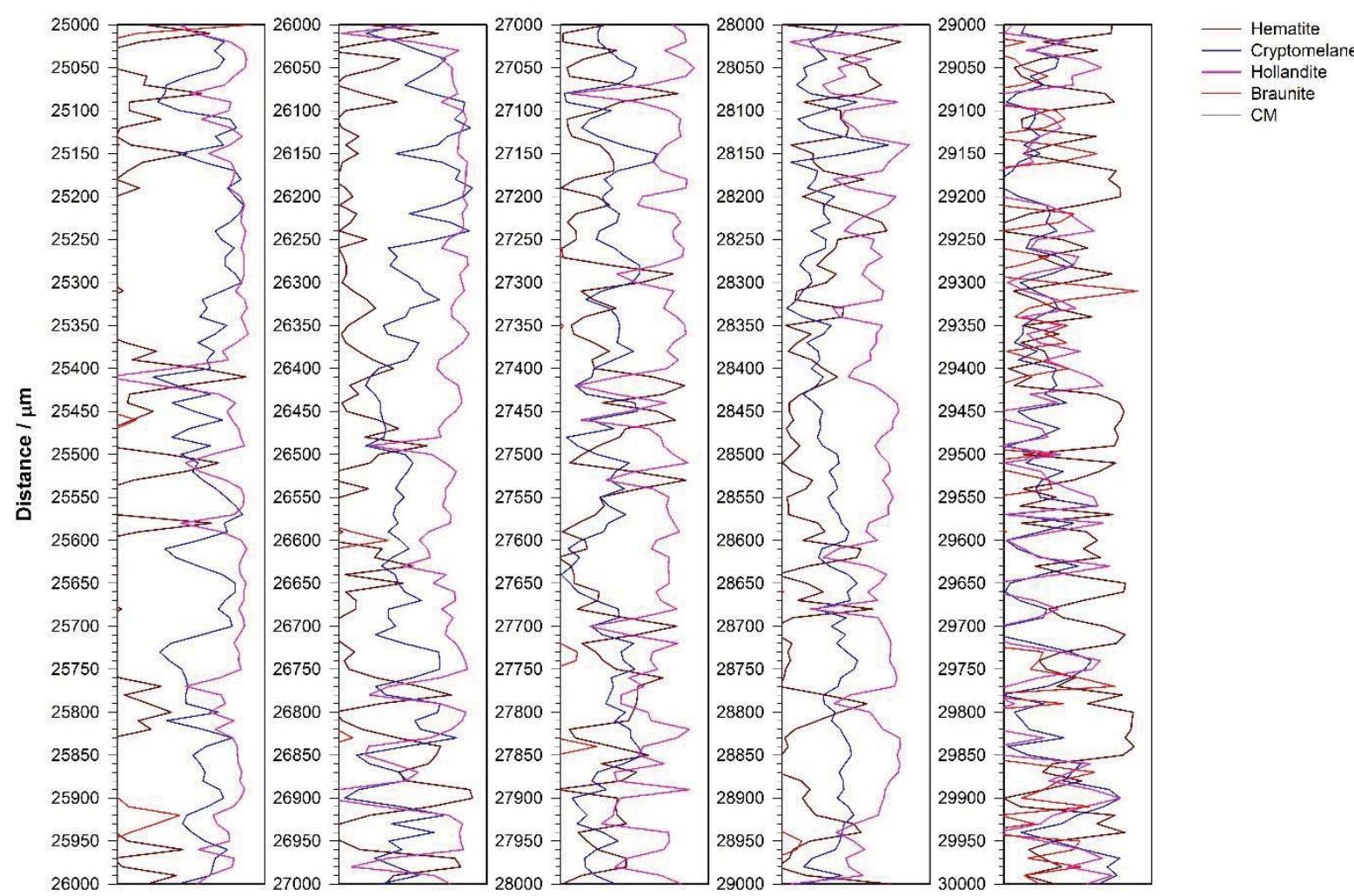

Normalized intensity / arbitrary unit 
81 (Mn-3)
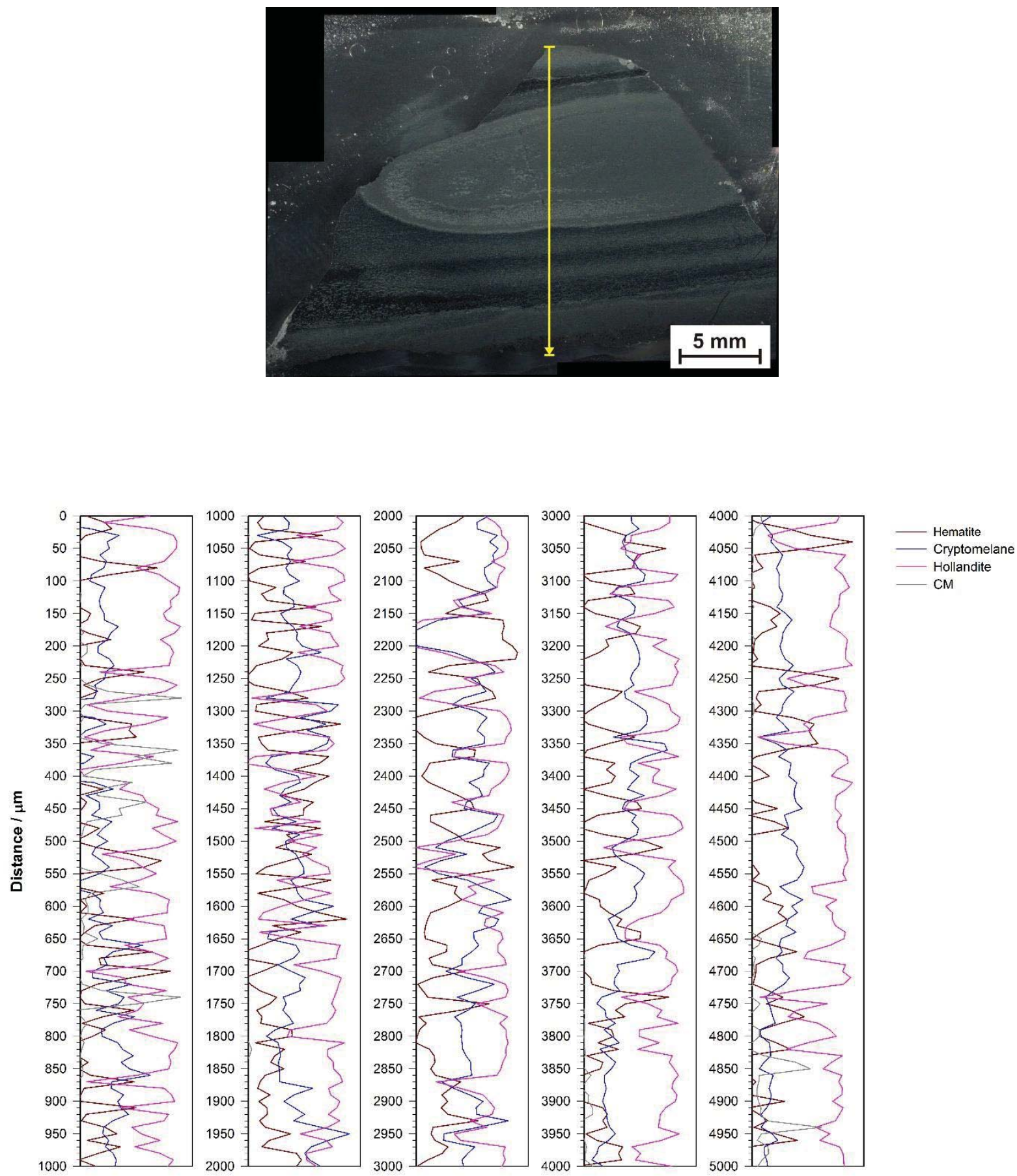

Normalized intensity / arbitrary unit 

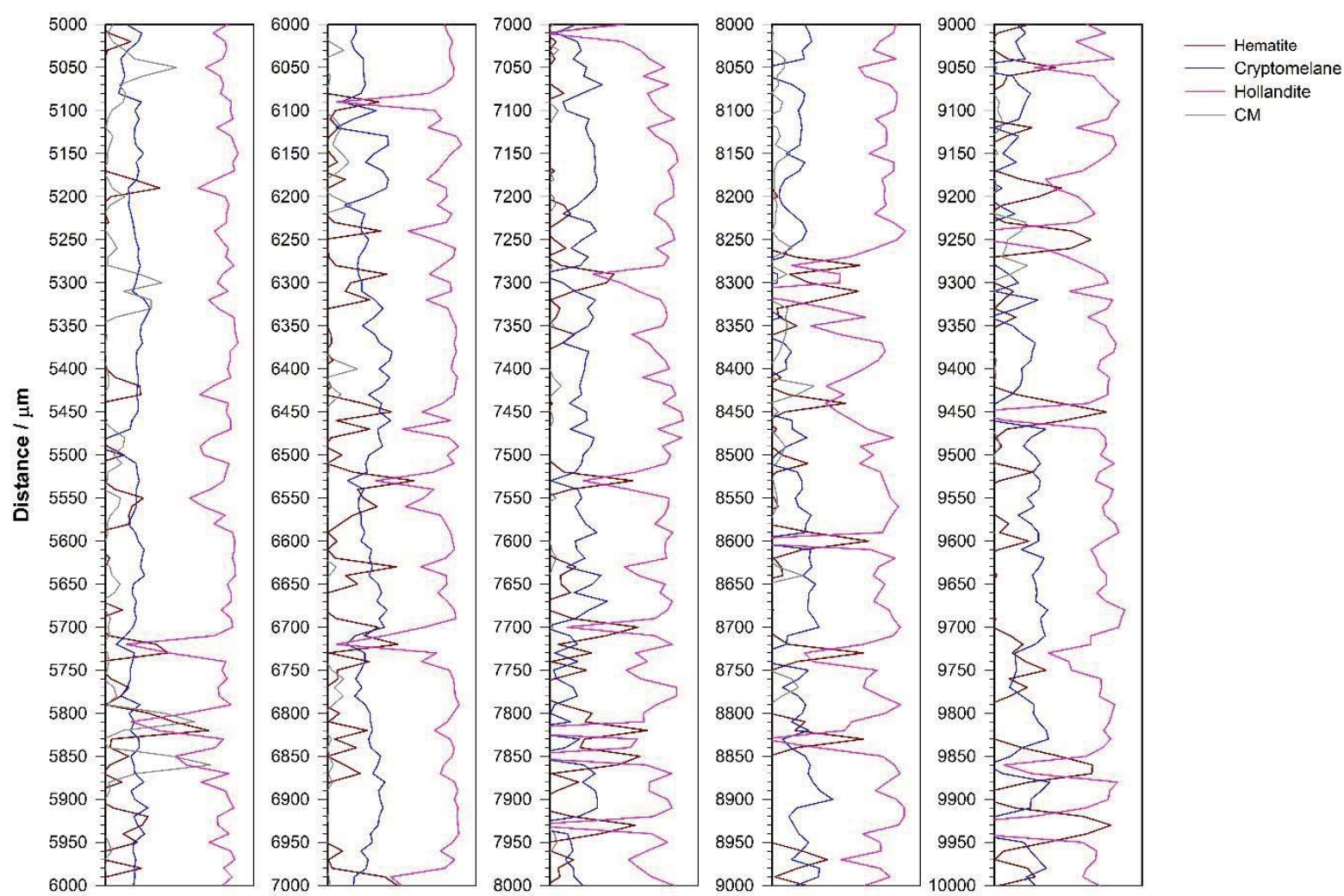

Normalized intensity / arbitrary unit
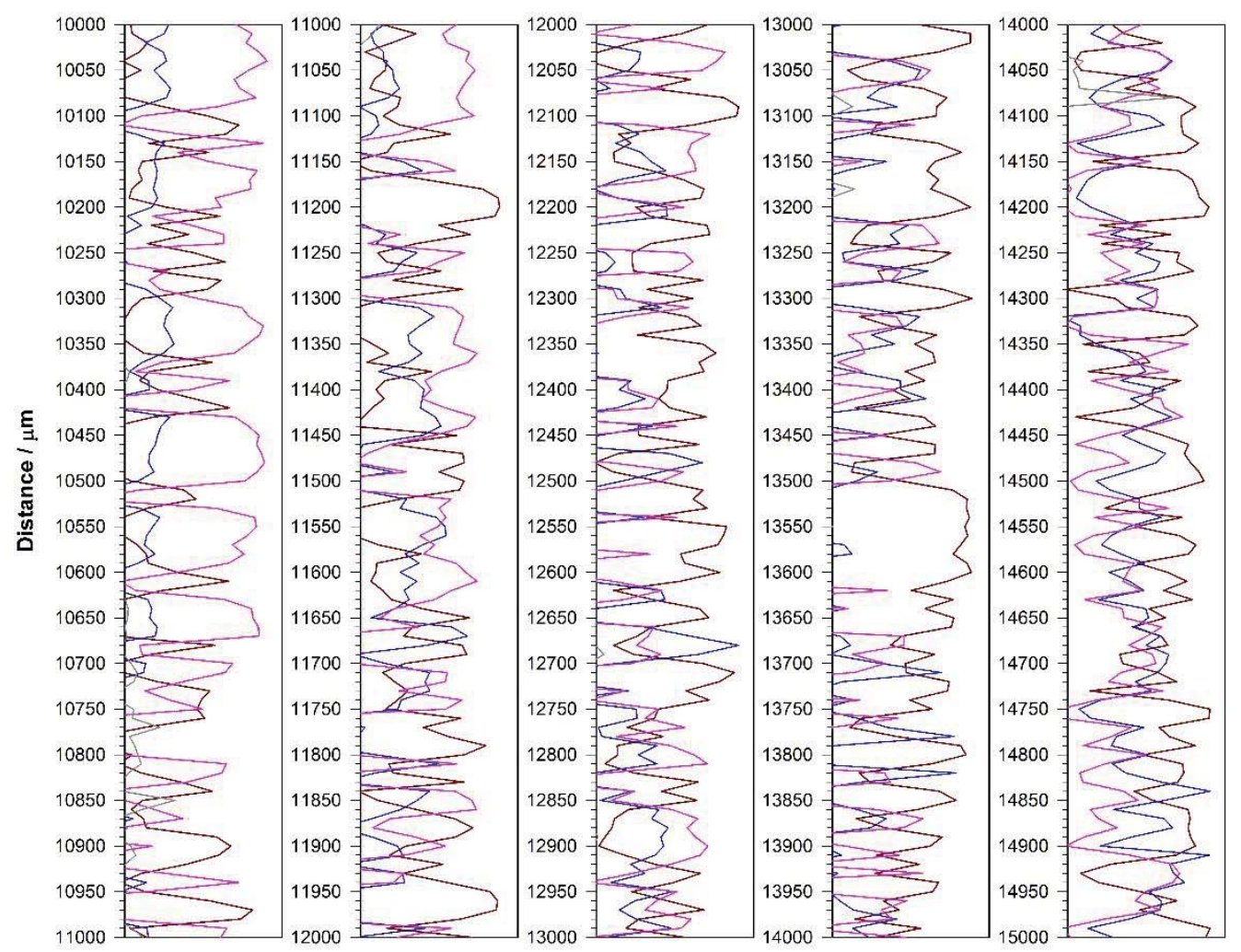

- Hematite

- Cryptomelane

CM

Normalized intensity / arbitrary unit 

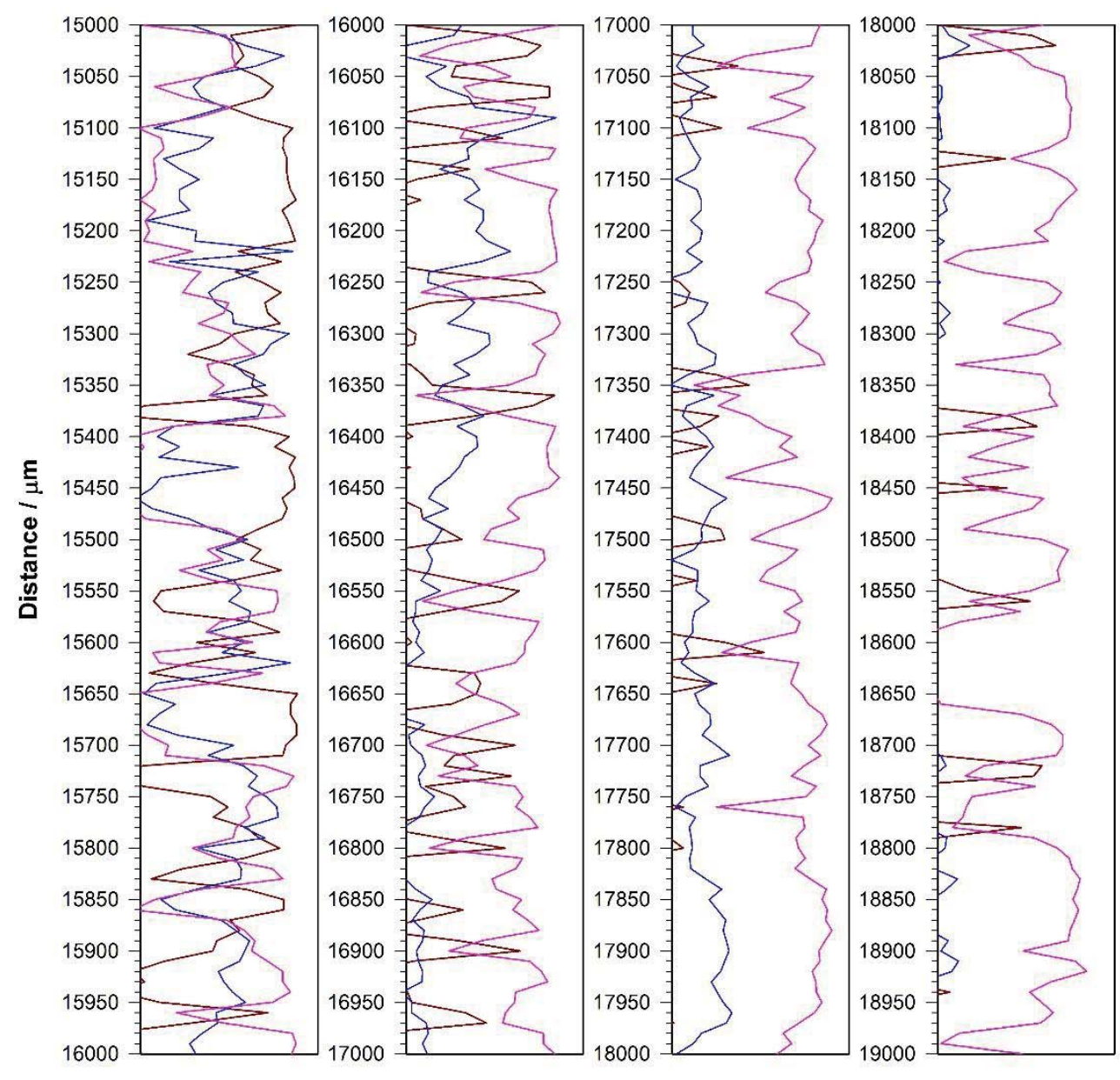

- Hematite
Cryptomelane
Hollandite

- $\mathrm{CM}$

Normalized intensity / arbitrary unit 
SI 13-Fig. Mineralogical distribution by Raman spectroscopy (sample 75-2)
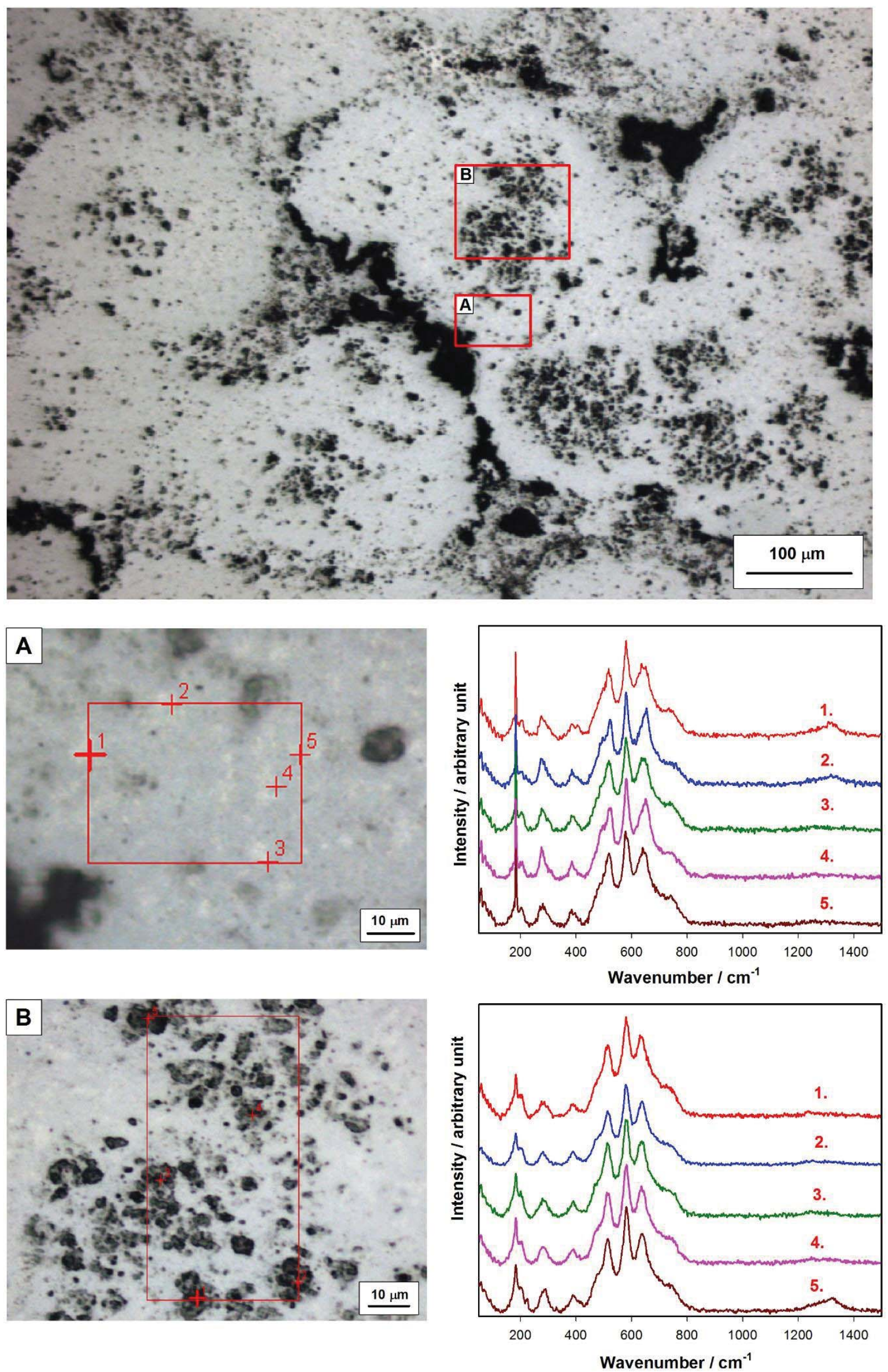

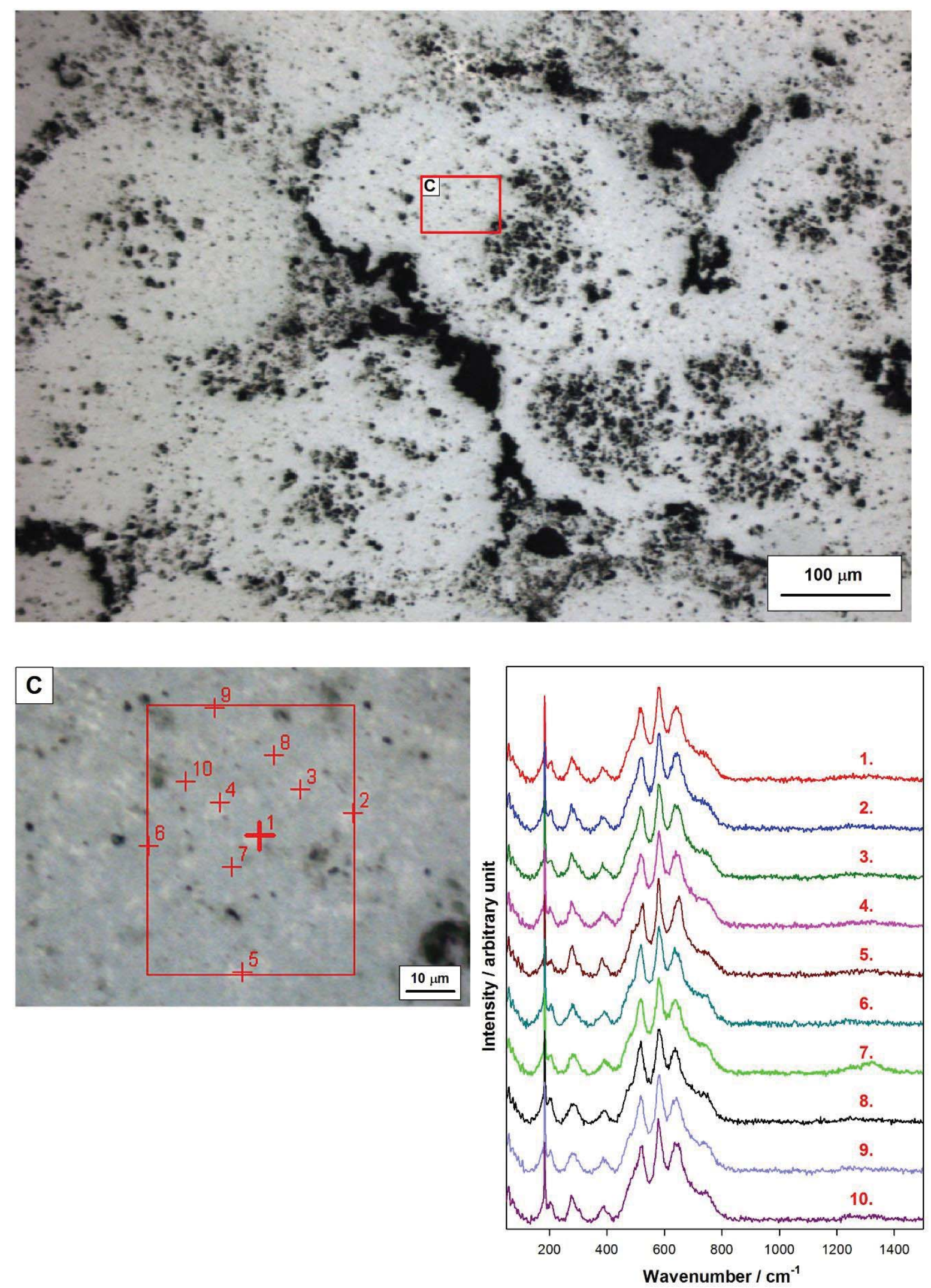

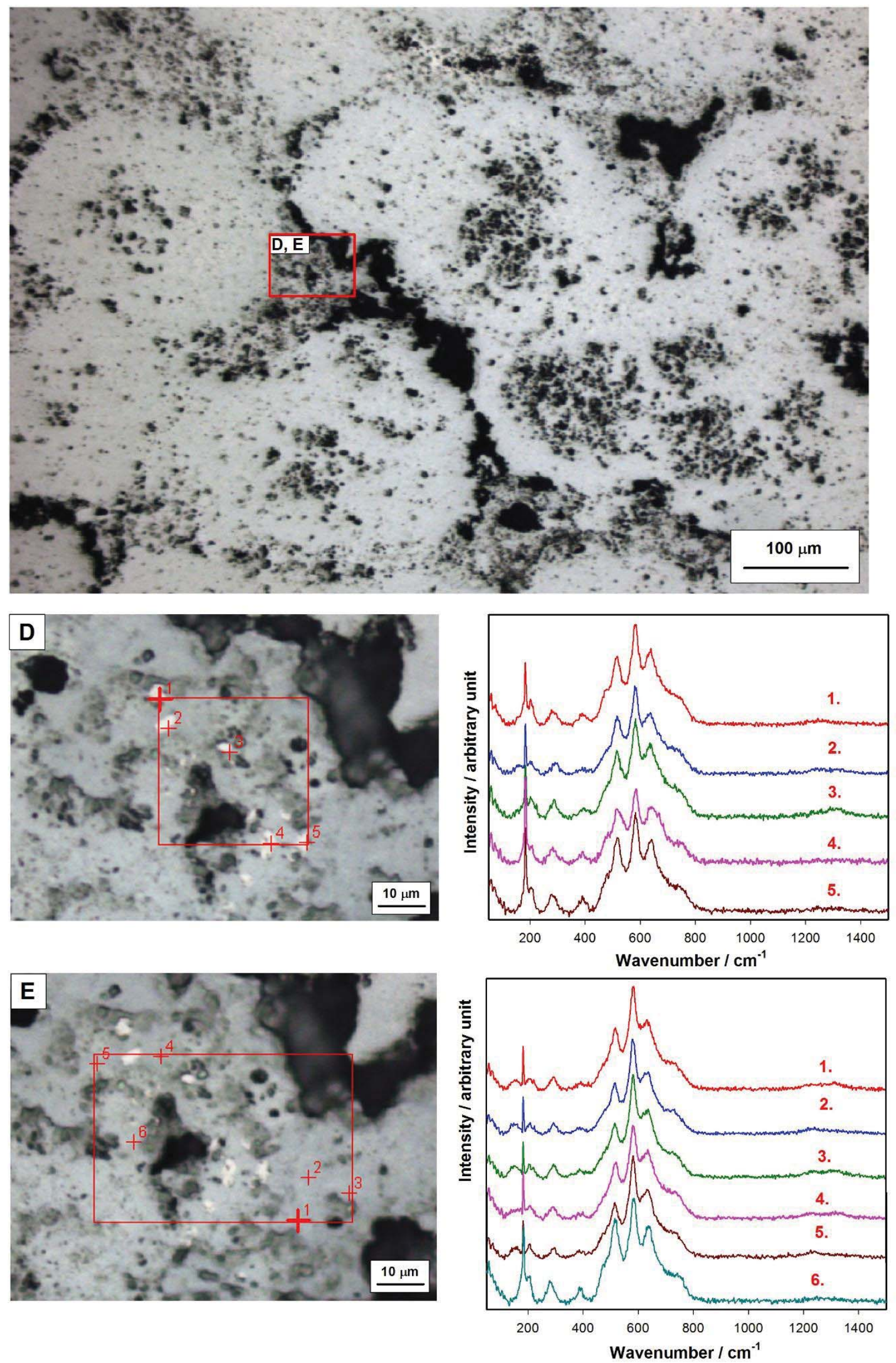

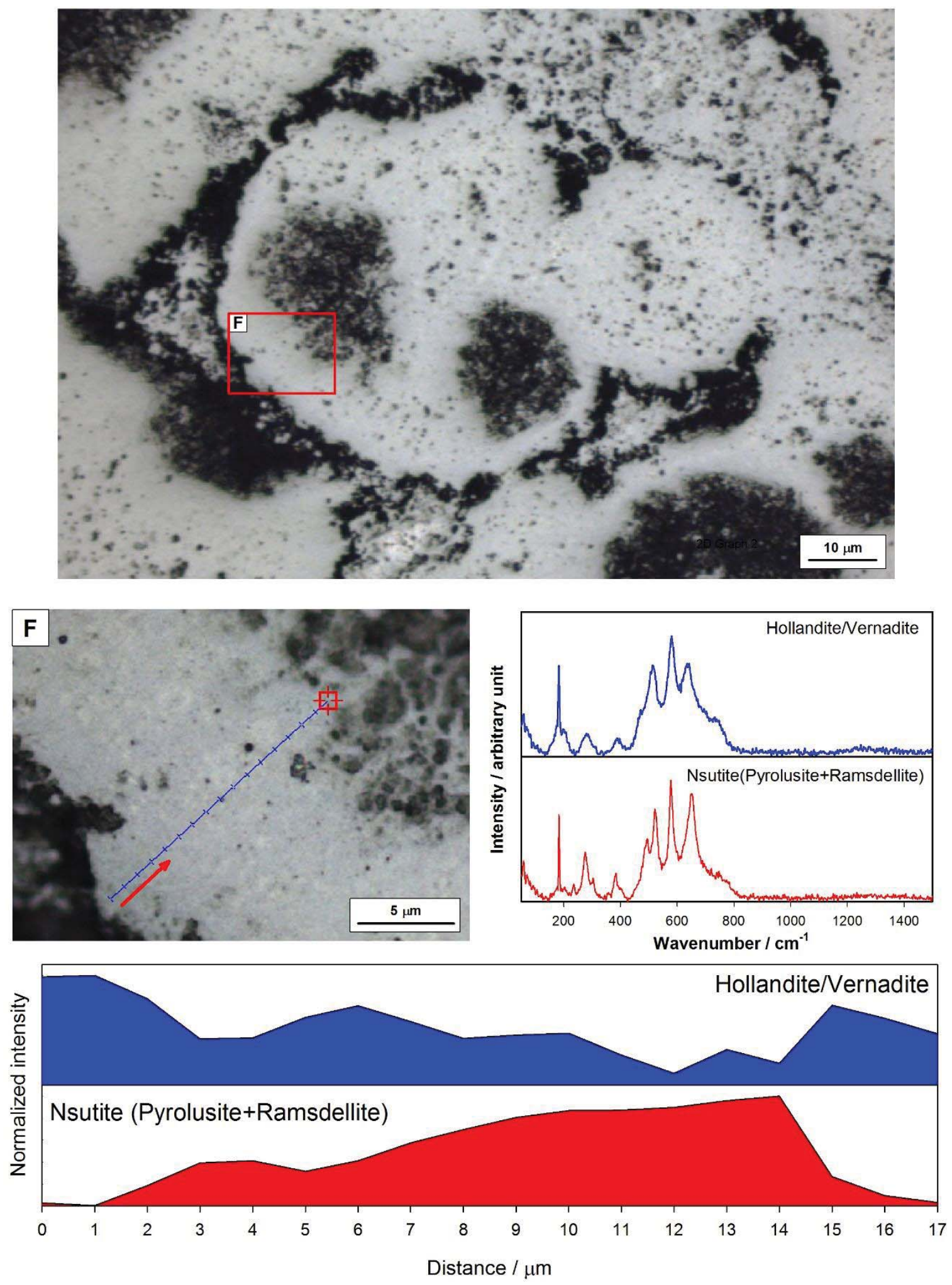

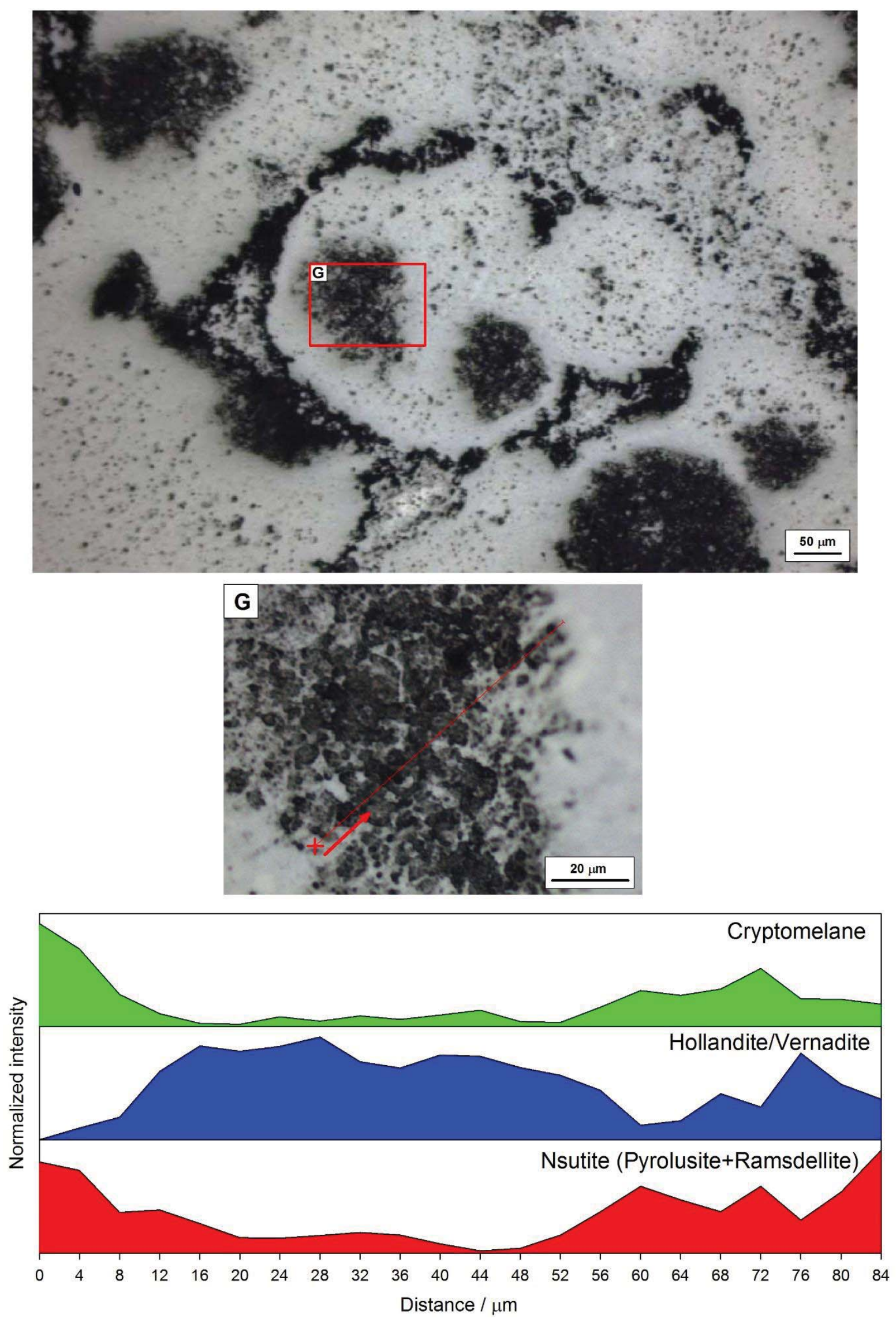

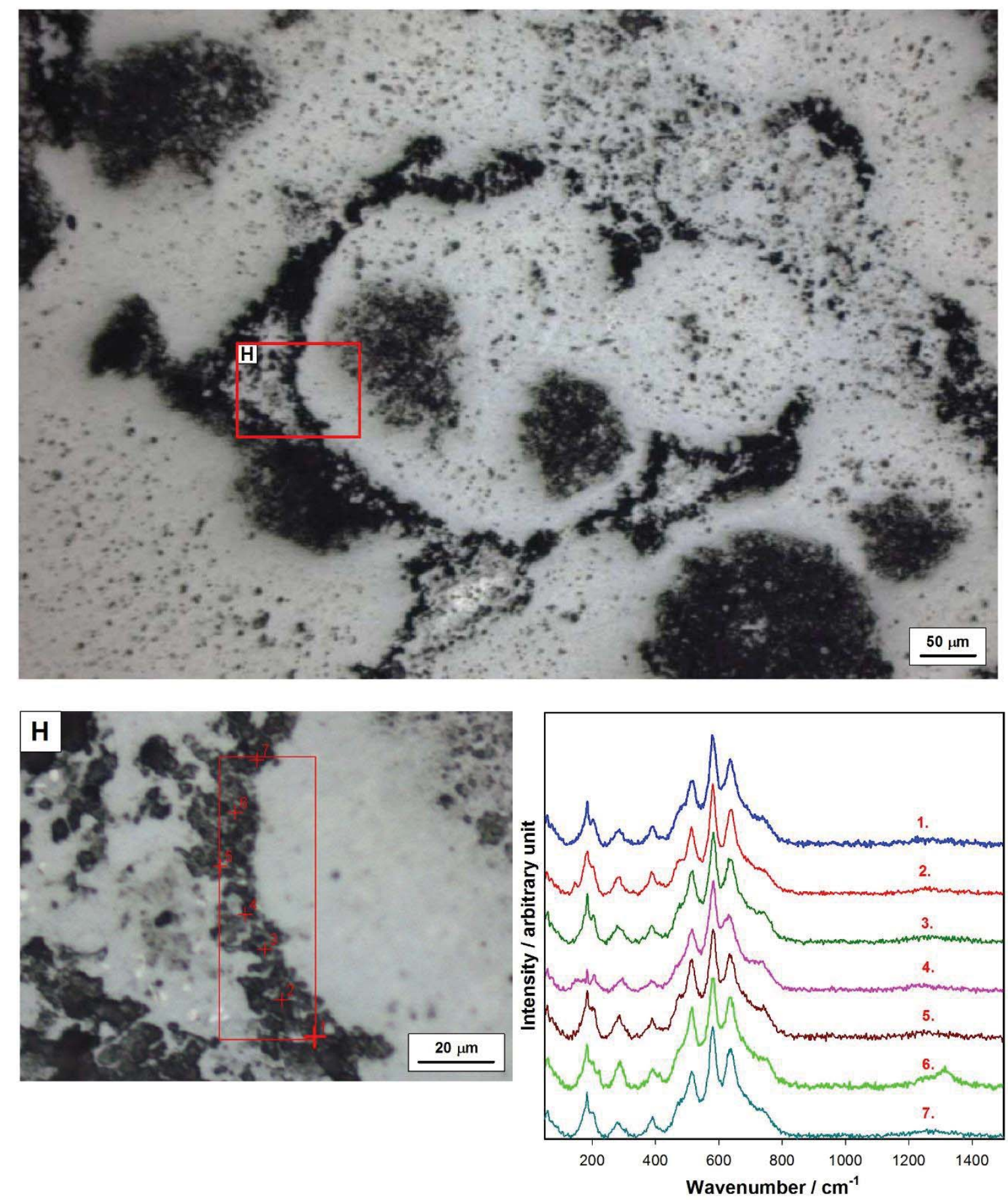

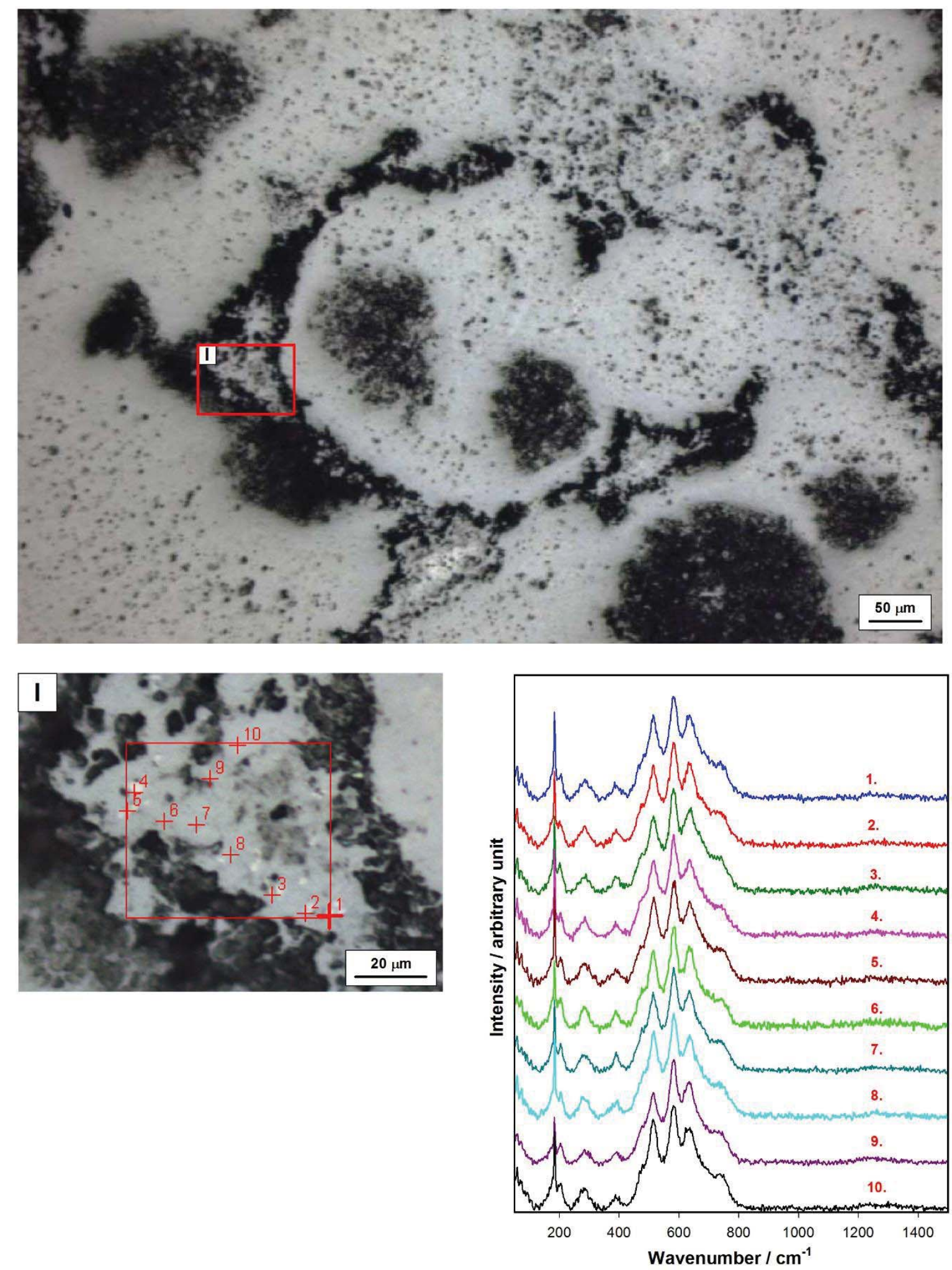

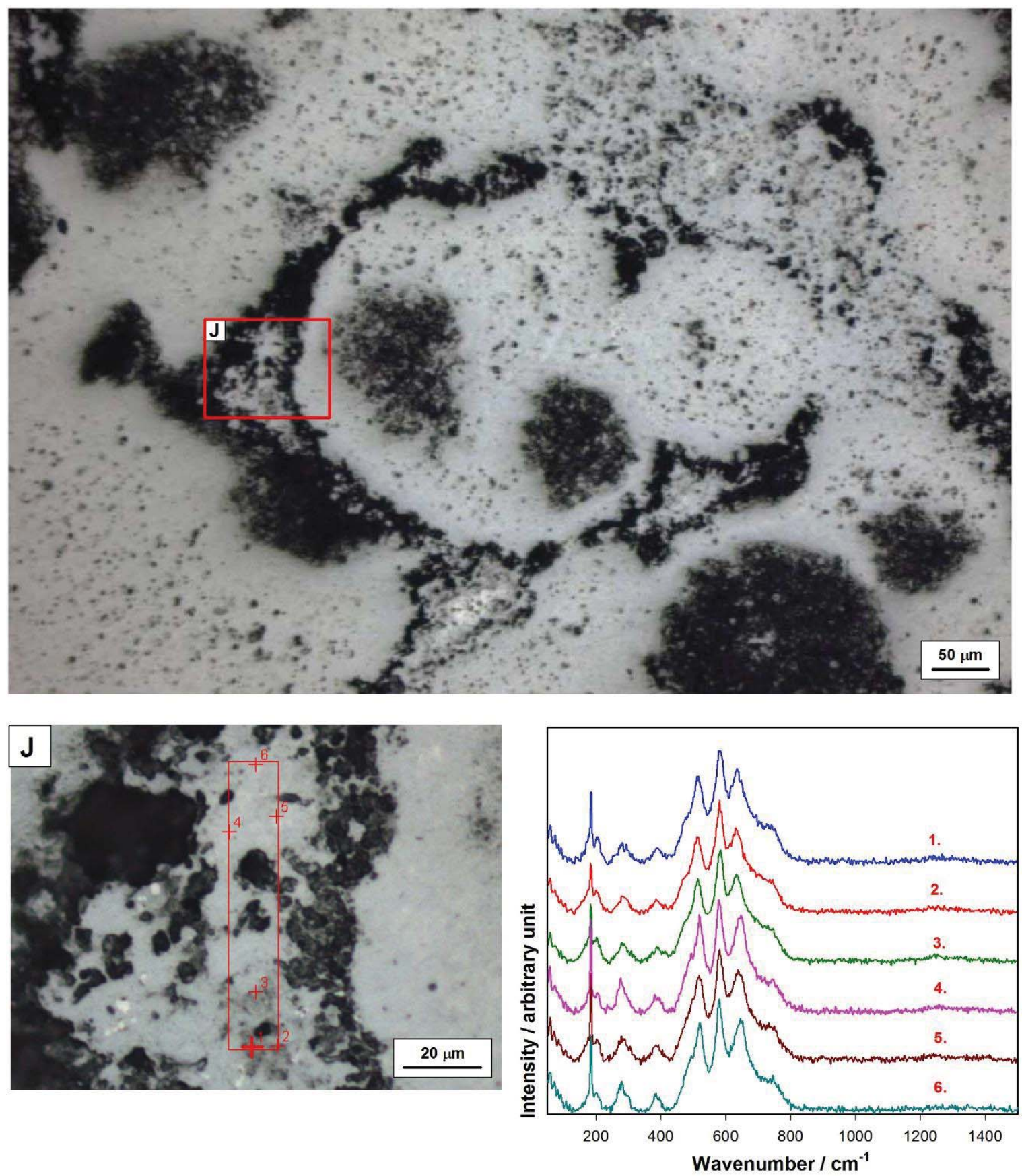

All the spectra taken in the fluffy parts, micronodules (cell colonies) and matrix material show dominant vernadite/hollandite-type Mn-oxides-hydroxides composition and more or less amount of cryptomelane and variable organic matter. The textural differences do not show significant mineralogical differences. The fluffy,micronodules are cell colonies (clusters), the central part consists of hollandite/vernadite $(\mathrm{G})$ and organic matter, around which cryptomelane and nsutite (pyrolusite + ramsdellite) occur. 


\section{SI 14-Fig. Mineral phases and distribution in spherical (bubble-like) structures measured by Raman spectroscopy}

\section{Outer part}

The "dark spots" in the matrix (M2 and M4 on Fig. 1) are mainly empty except dark porous inner rim with various thickness, which consist of hollandite type Mn oxide phase (dominant phase), cryptomelane and goethite (Fig. 2-5). The matrix among the "dark spots" (M1 and M3 on Fig. 1) is built up also by hollandite, cryptomelane and goethite (Fig. 2-5). The occurrence and distribution of the three minerals are consistent in the matrix material any trend in their distribution was not observable.

\section{Rim}

The non-porous rim of the spherical structure „bubble-like structure” (001 line on Fig. 1) mainly consists of hollandite and cryptomelane in variable amounts (Fig. 6). Rarely among the hollandite-cryptomelane flakes fine-grained clusters of goethite occur (Fig. 6). The distribution of the mentioned phases are indicative of gradually drop of peak intensity related to hollandite and cryptomelane phases in the direction from the spherical structure ("bubble-like structure)" to the matrix (Fig. 6).

\section{Inner part}

The matrix of the inner part of the spherical (bubble-like) structure is composed of very fine grained goethite (ferrihydrite) and little particles of Mn oxides (hollandite, cryptomelane in variable amounts), however hollandite is the dominant in the dark spots (Fig. 7-11). The mineral composition of the matrix and the dark spots show a unified distribution, any difference or significant trend in the matrix or in the dark spots was not detected.

Representative sample areas where Raman spectra were acquired (the other measured areas have similar mineral composition and distribution). 


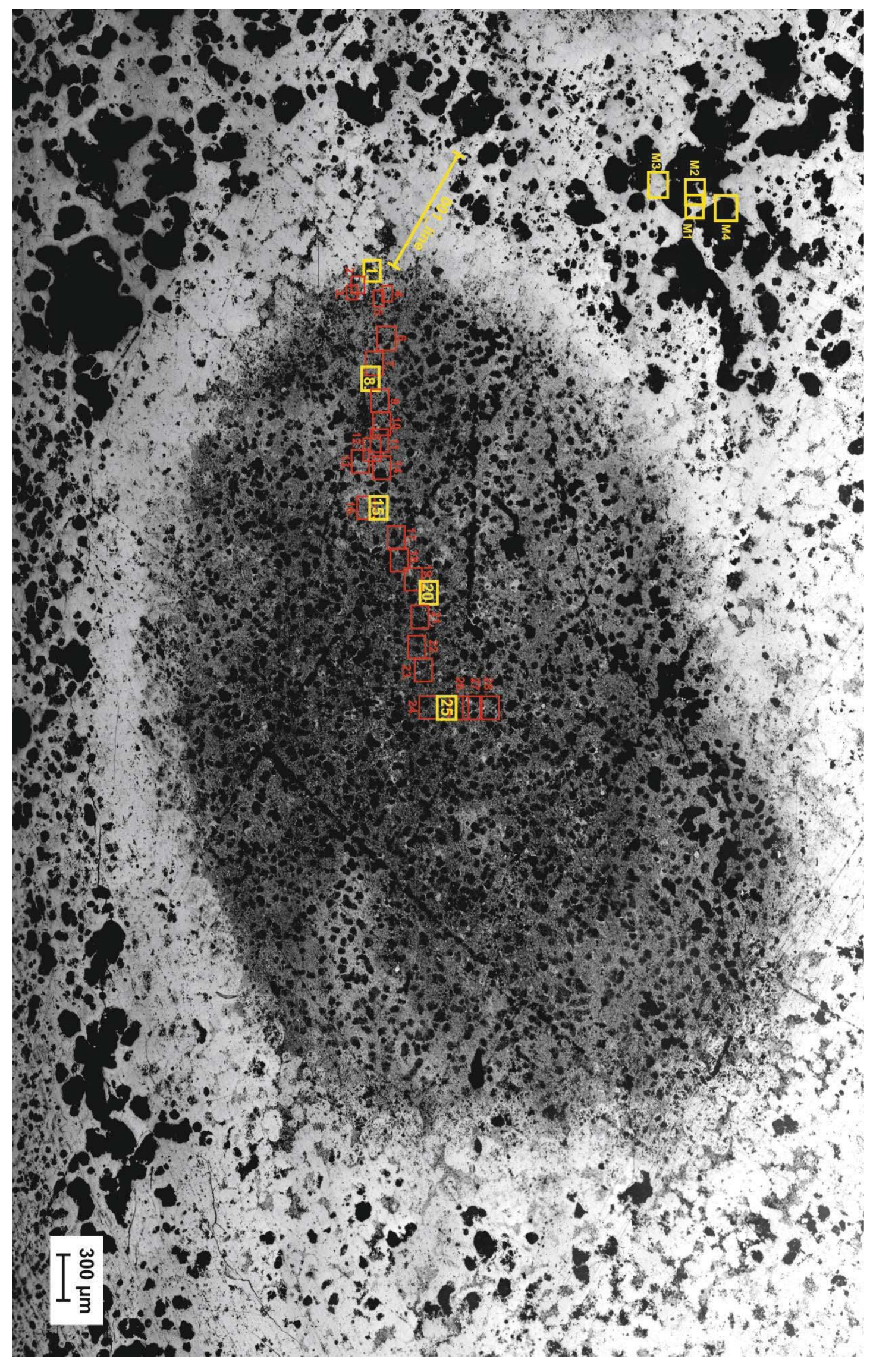

Figure 1.: Composite map from the investigated spherical (bubble-like) structure - measured areas are indicated on the picture (those places are detailed in this short report are in yellow color) 

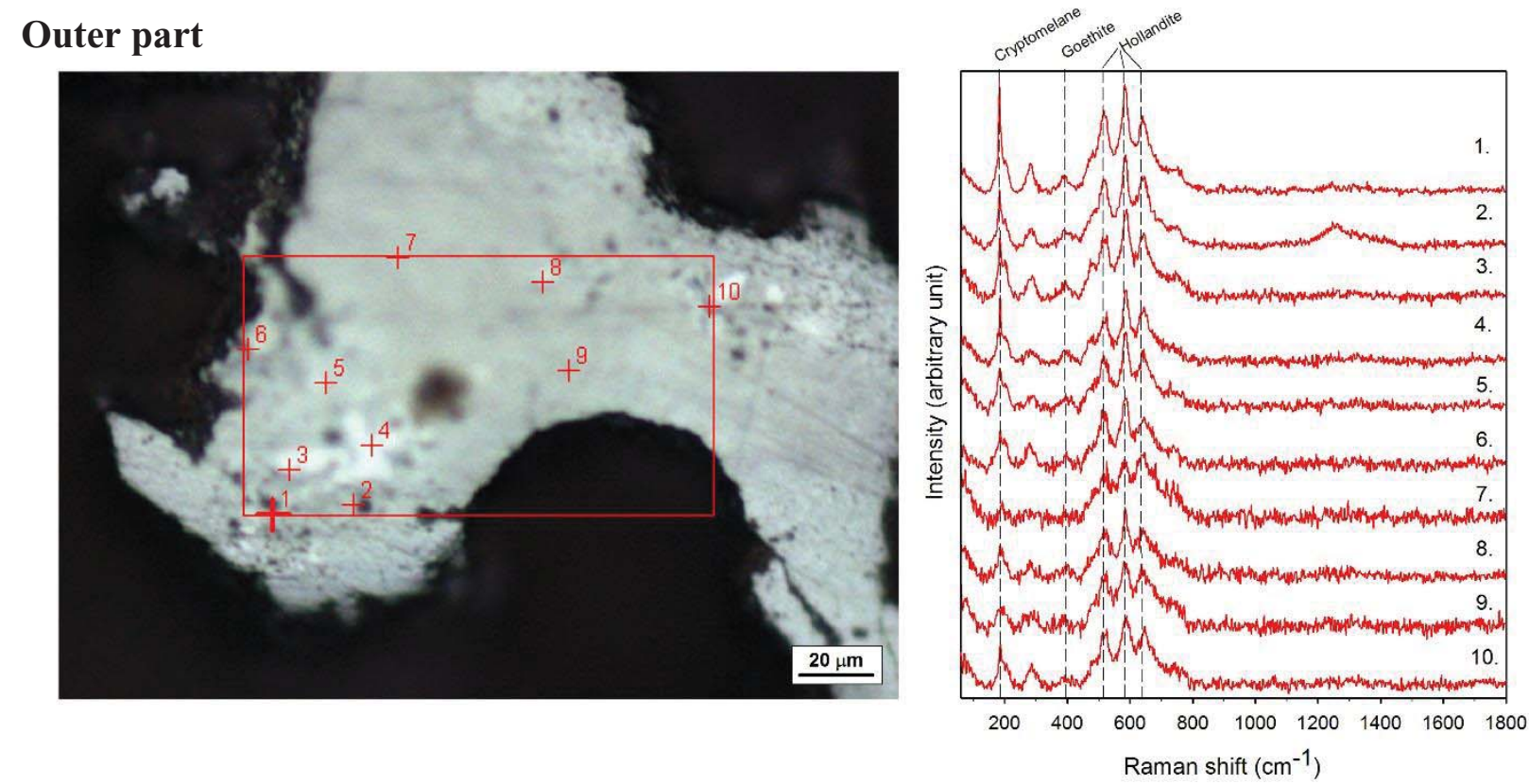

Figure 2.: Measuring points and Raman spectra from place indicated by M1 on Fig. 1.
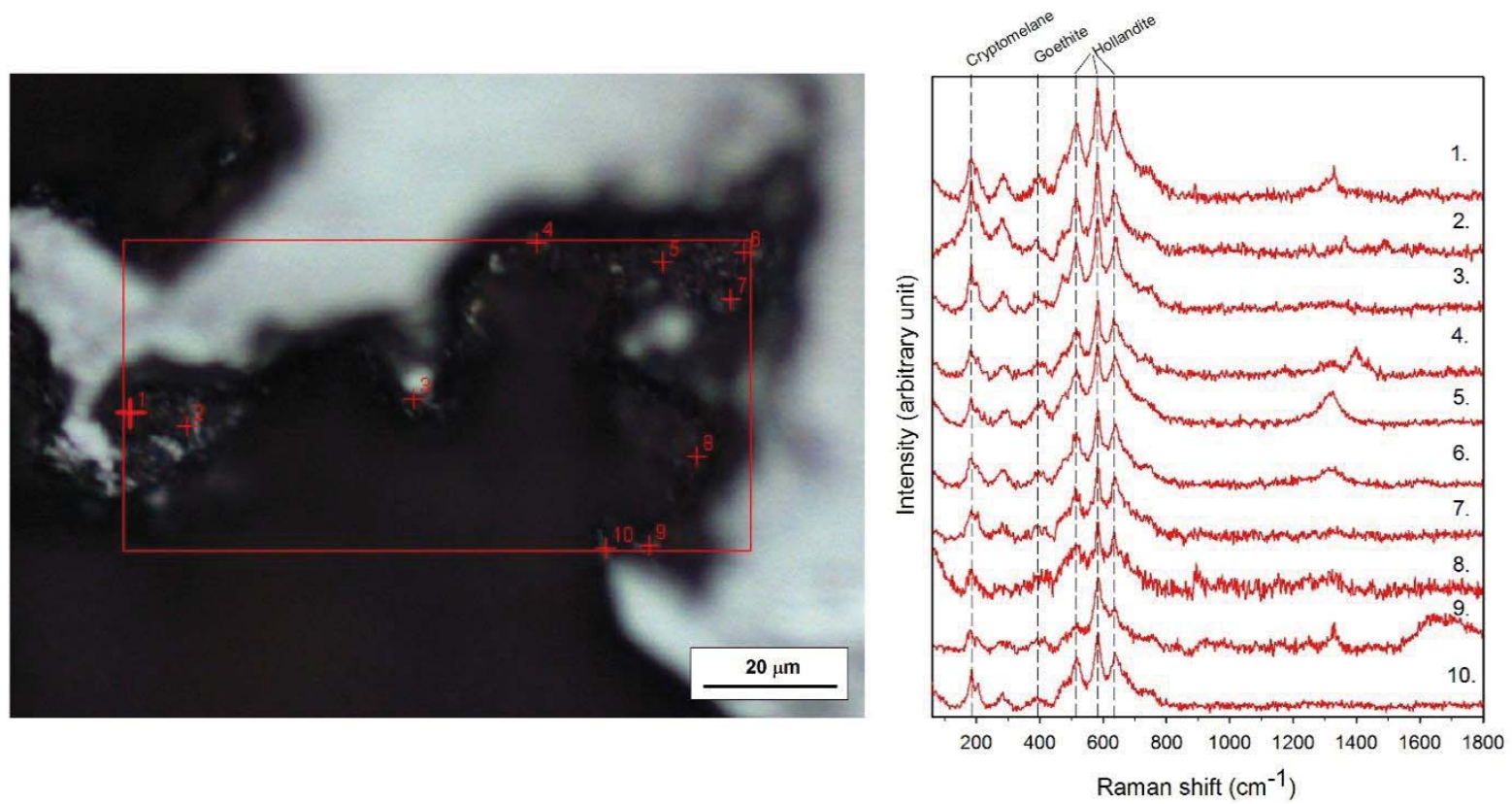

Figure 3.: Measuring points and Raman spectra from place indicated by M2 on Fig. 1. 

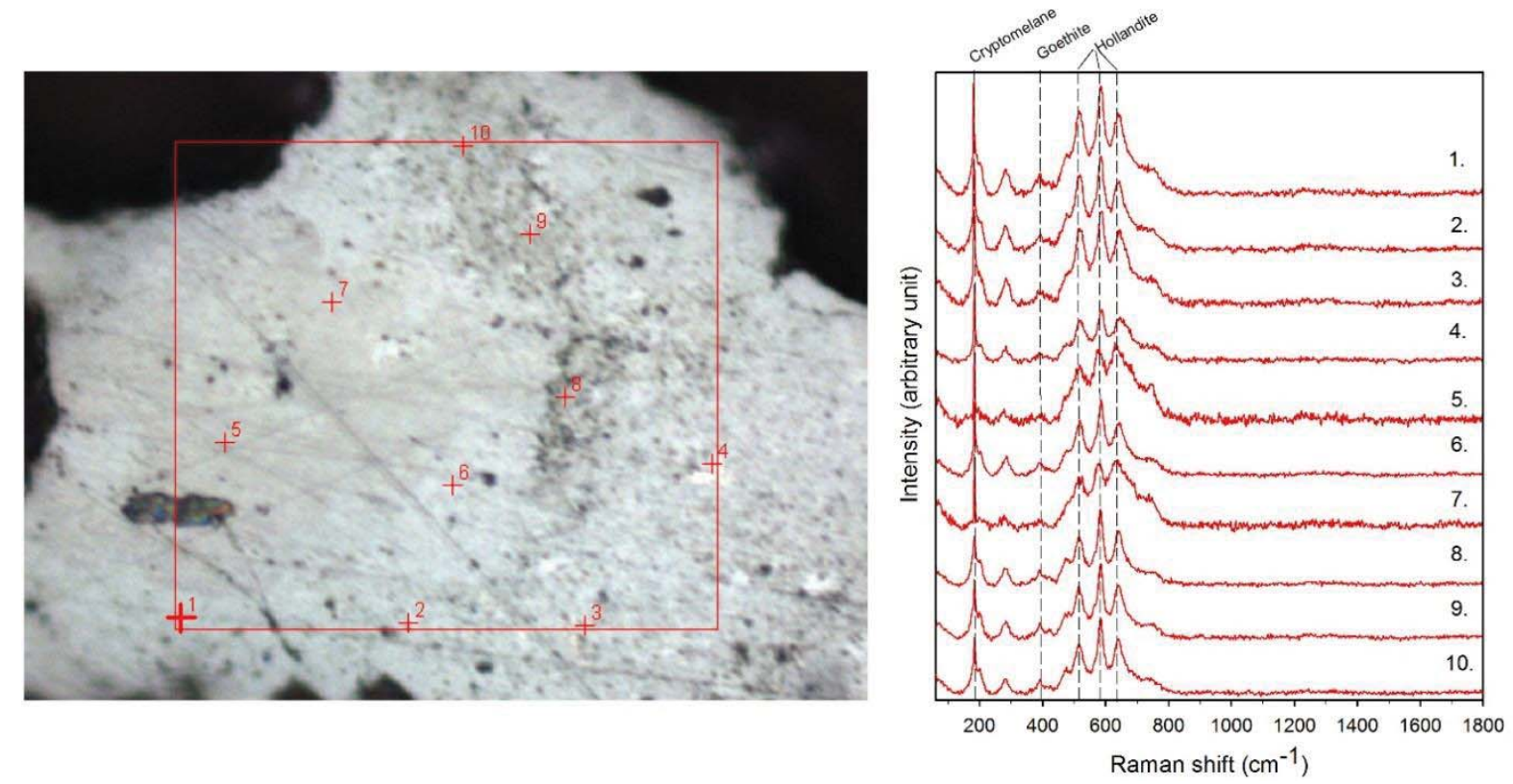

Figure 4.: Measuring points and Raman spectra from place indicated by M3 on Fig. 1.
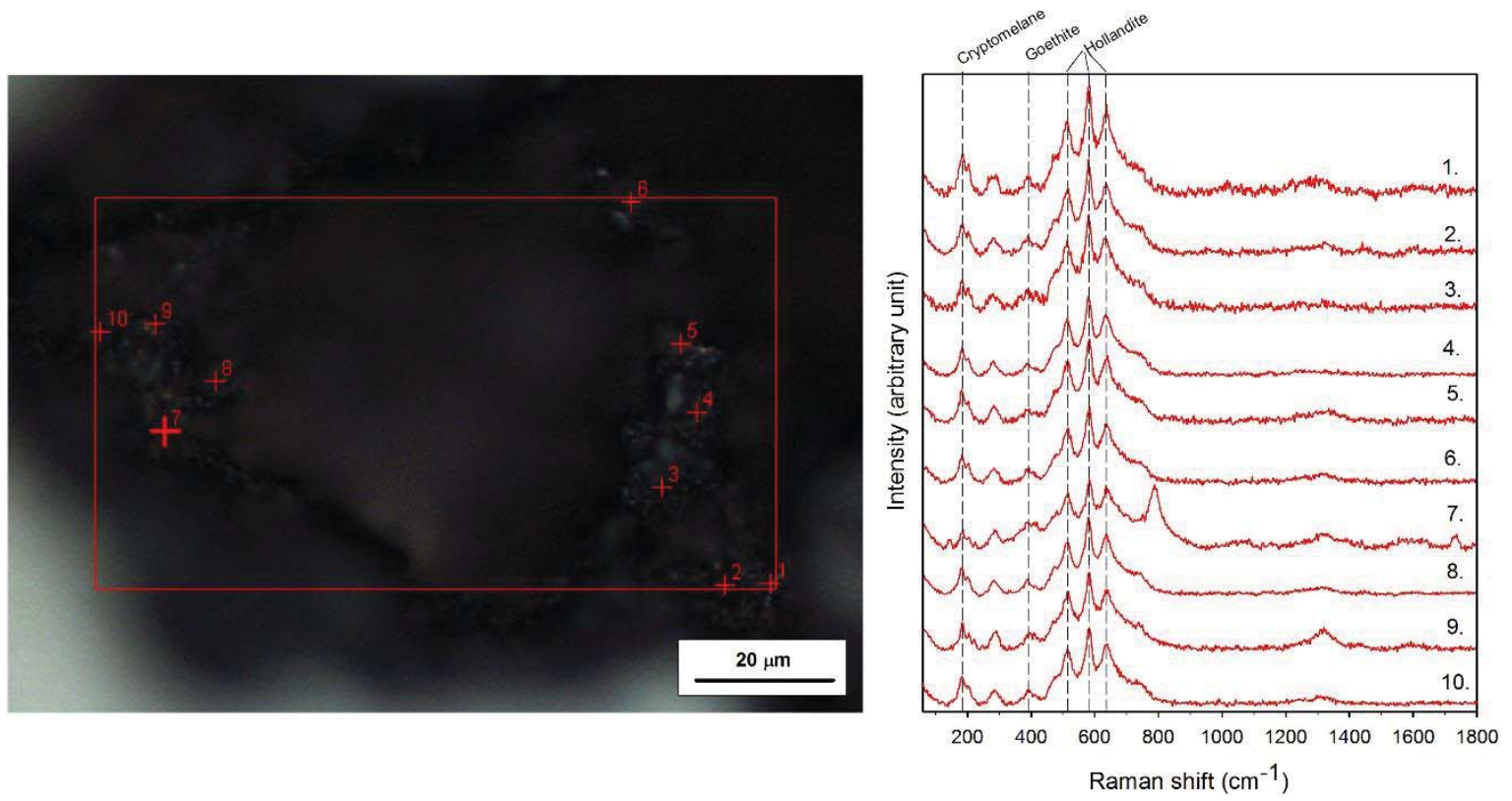

Figure 5.: Measuring points and Raman spectra from place indicated by M4 on Fig. 1.

Peak at $800 \mathrm{~cm}^{-1}$ can be $\mathrm{UO} 2$ or janhaugite $(\mathrm{Na}, \mathrm{Ca})_{3}\left(\mathrm{Mn}^{2+}, \mathrm{Fe}^{2+}\right)_{3}(\mathrm{Ti}, \mathrm{Zr}, \mathrm{Nb})_{2}\left(\mathrm{Si}_{2} \mathrm{O}_{7}\right)_{2} \mathrm{O}_{2}(\mathrm{OH}, \mathrm{F})_{2}$ 


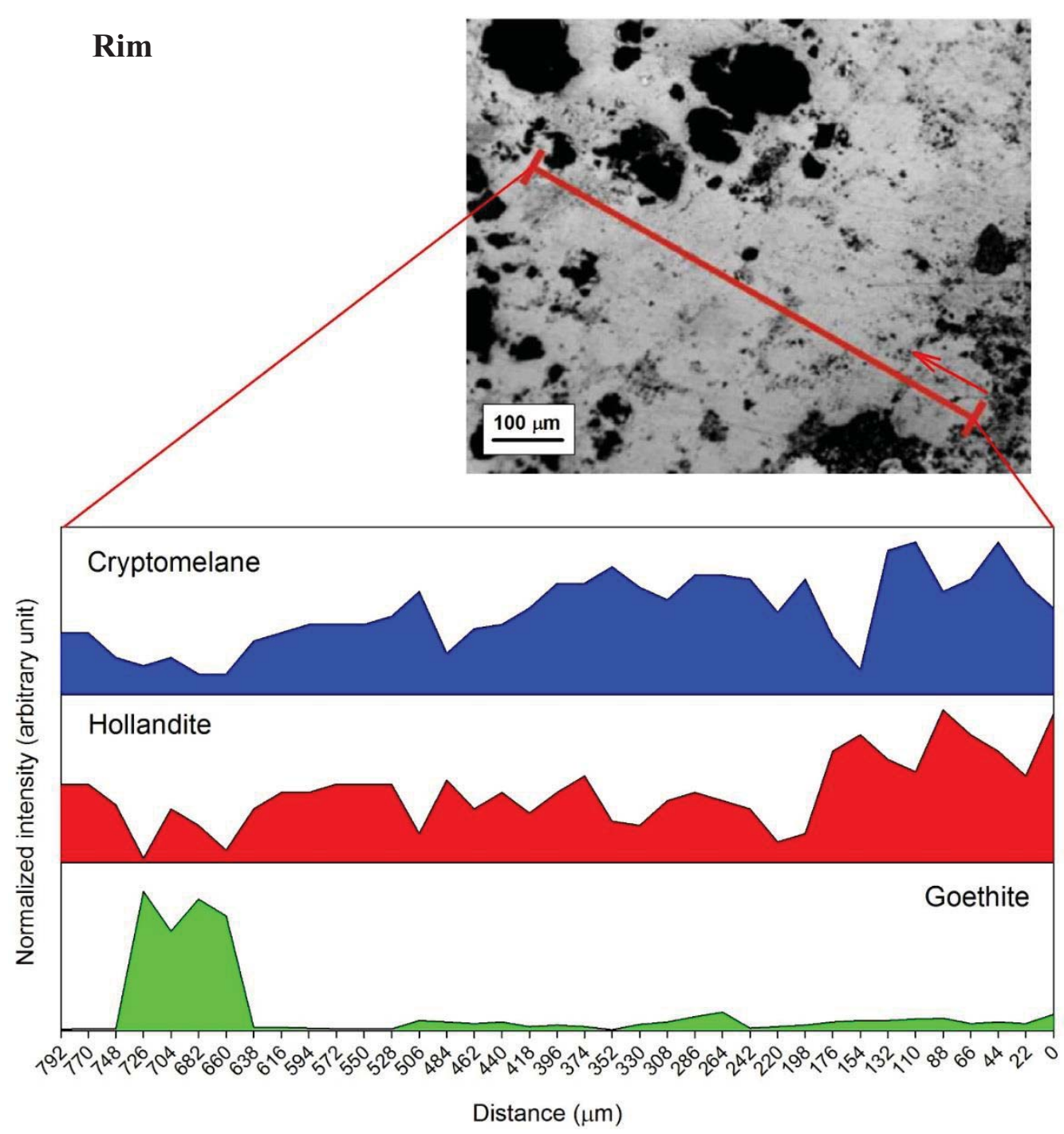

Figure 6.: 001-line map (indicated by yellow line marked with 001_line caption on the image). 

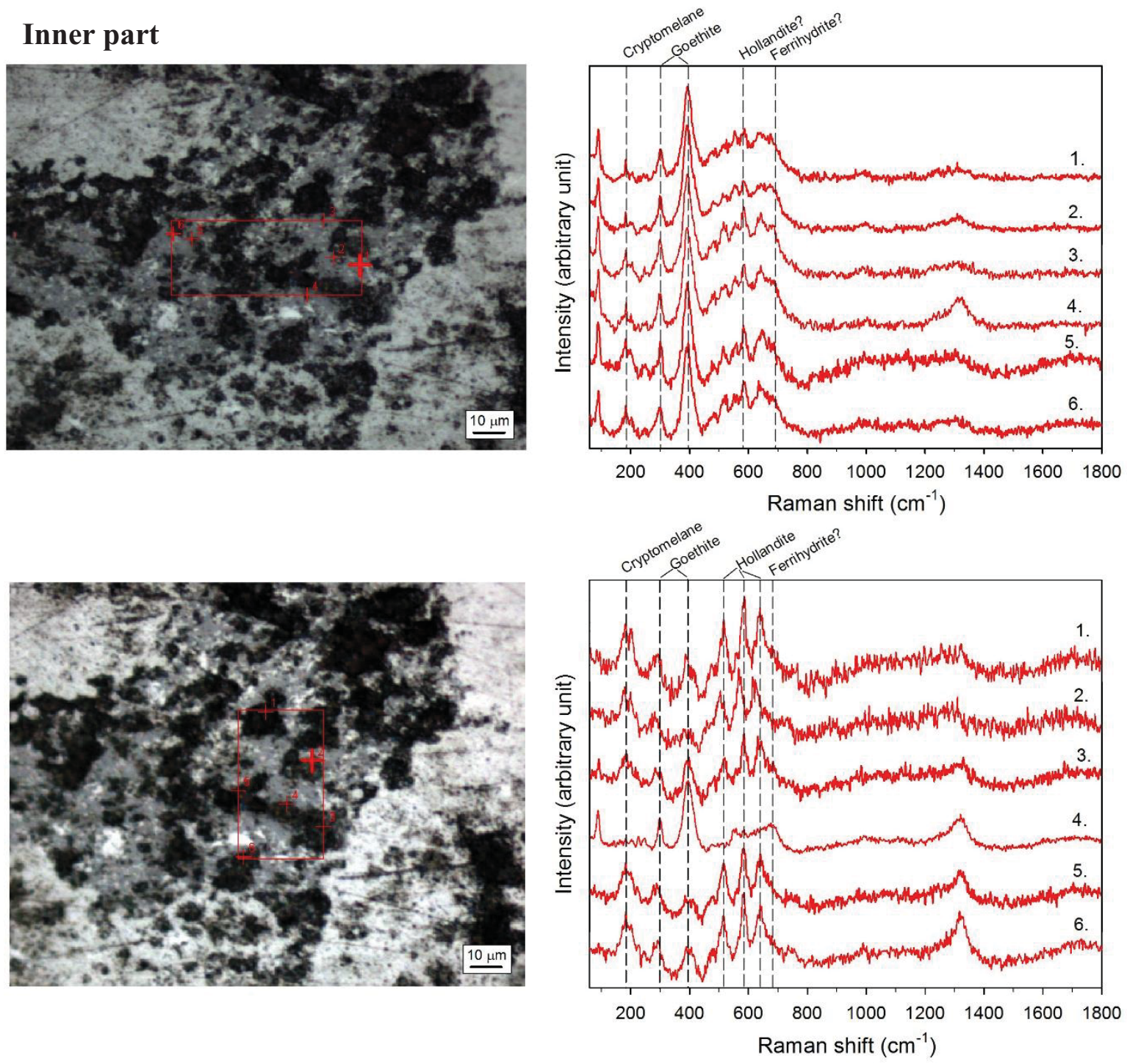

Figure 7.: Map indicated on the composite picture by yellow box marked by number 1 .

The leftmost part of the spherical (bubble-like) structure consists of goethite (ferrihydrite) and little particles of Mn oxides (hollandite, cryptomelane in various amount), however hollandite is the dominant in the dark spots. 

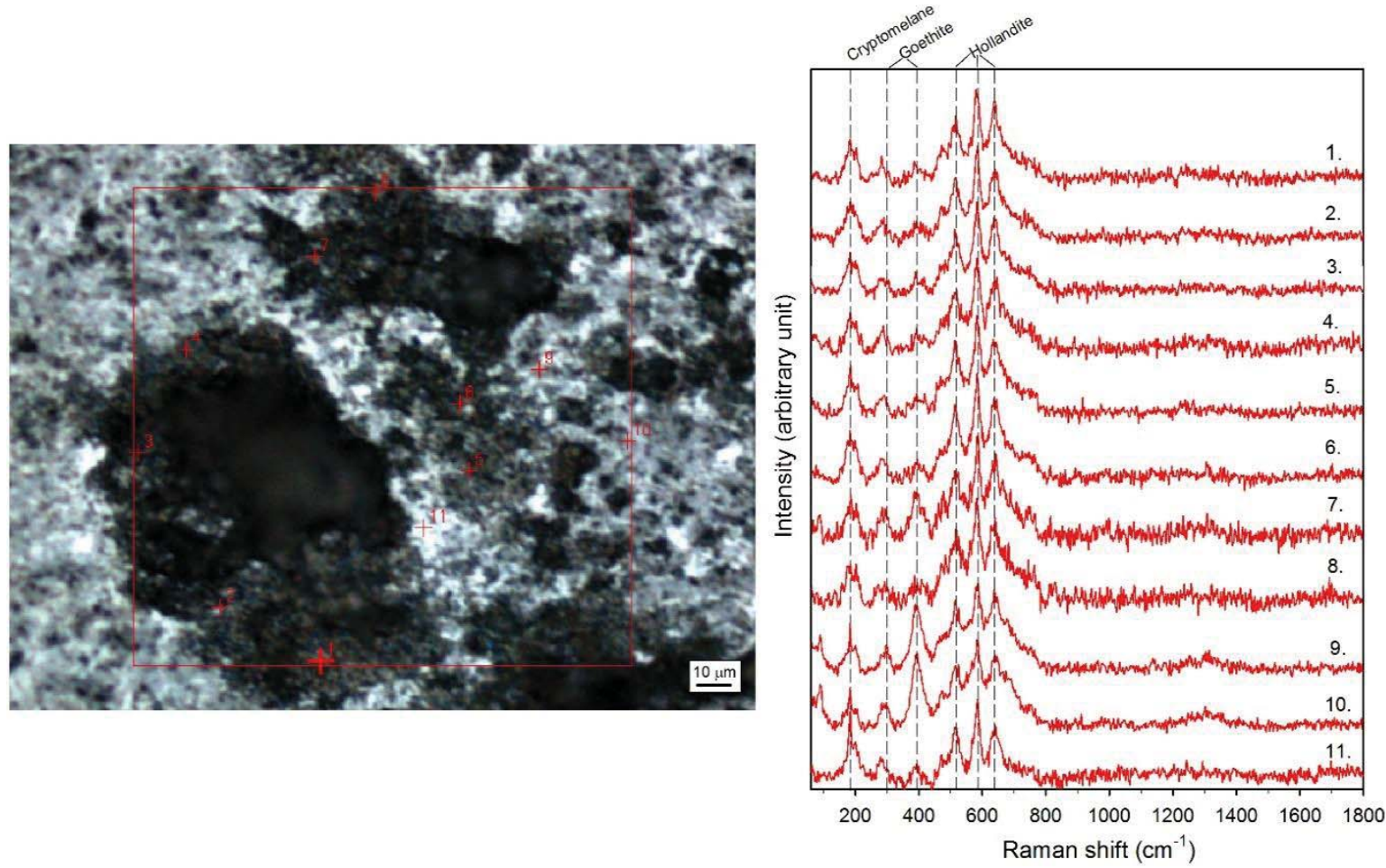

Figure 8.: Map indicated on the composite picture by yellow box marked by number 8 . The dark spots have porous hollandite (cryptomelane, goethite) rims indicated on (Fig. 8. $1-4,7,8)$ while in the matrix among dark spots the Mn oxide has higher cryptomelane content (Fig 8. 5, 6, 9-11).
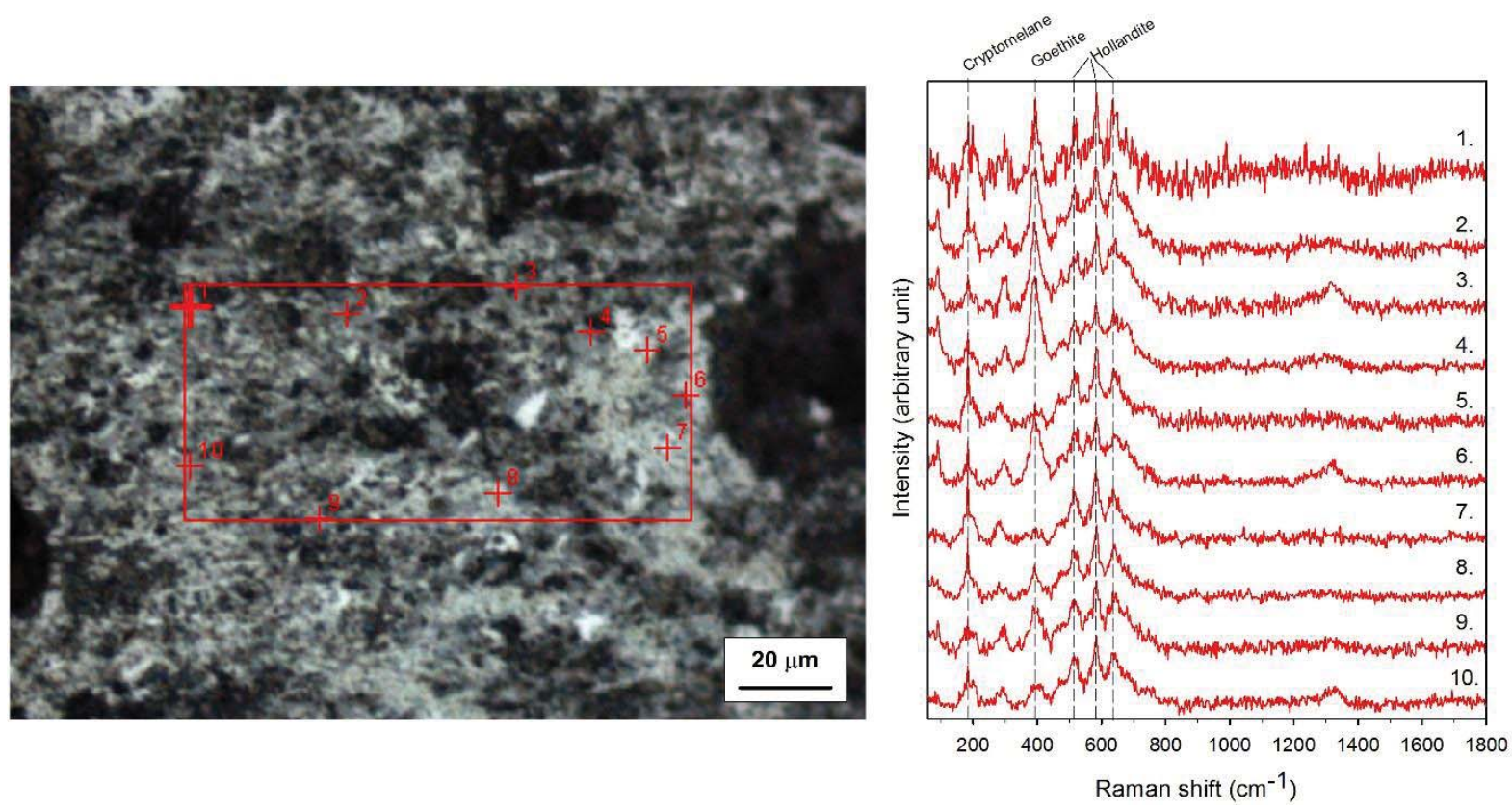

Figure 9.: Map indicated on the composite picture by yellow box marked by number 15 . 

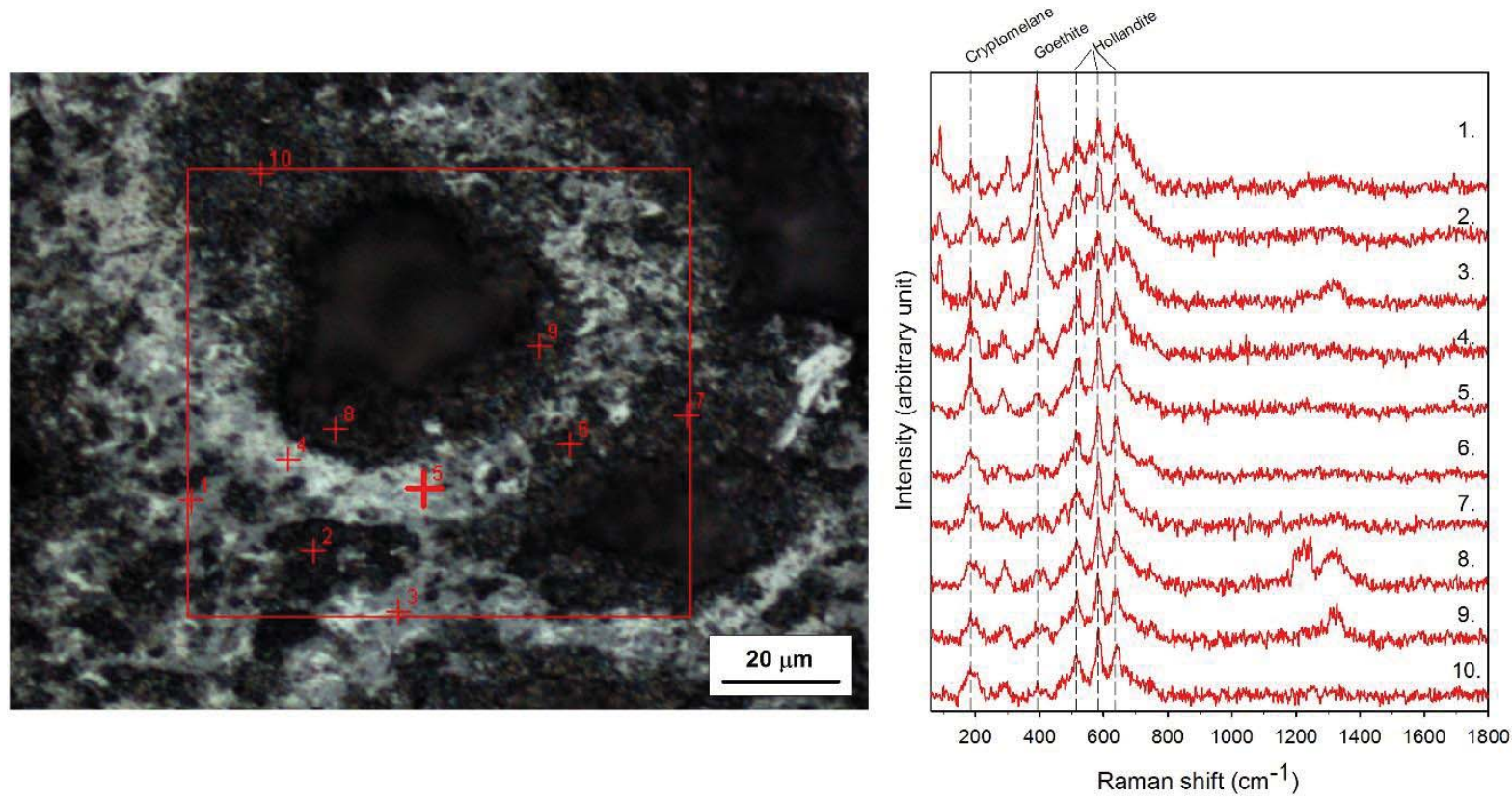

Figure 10.: Map indicated on the composite picture by yellow box marked by number 20.
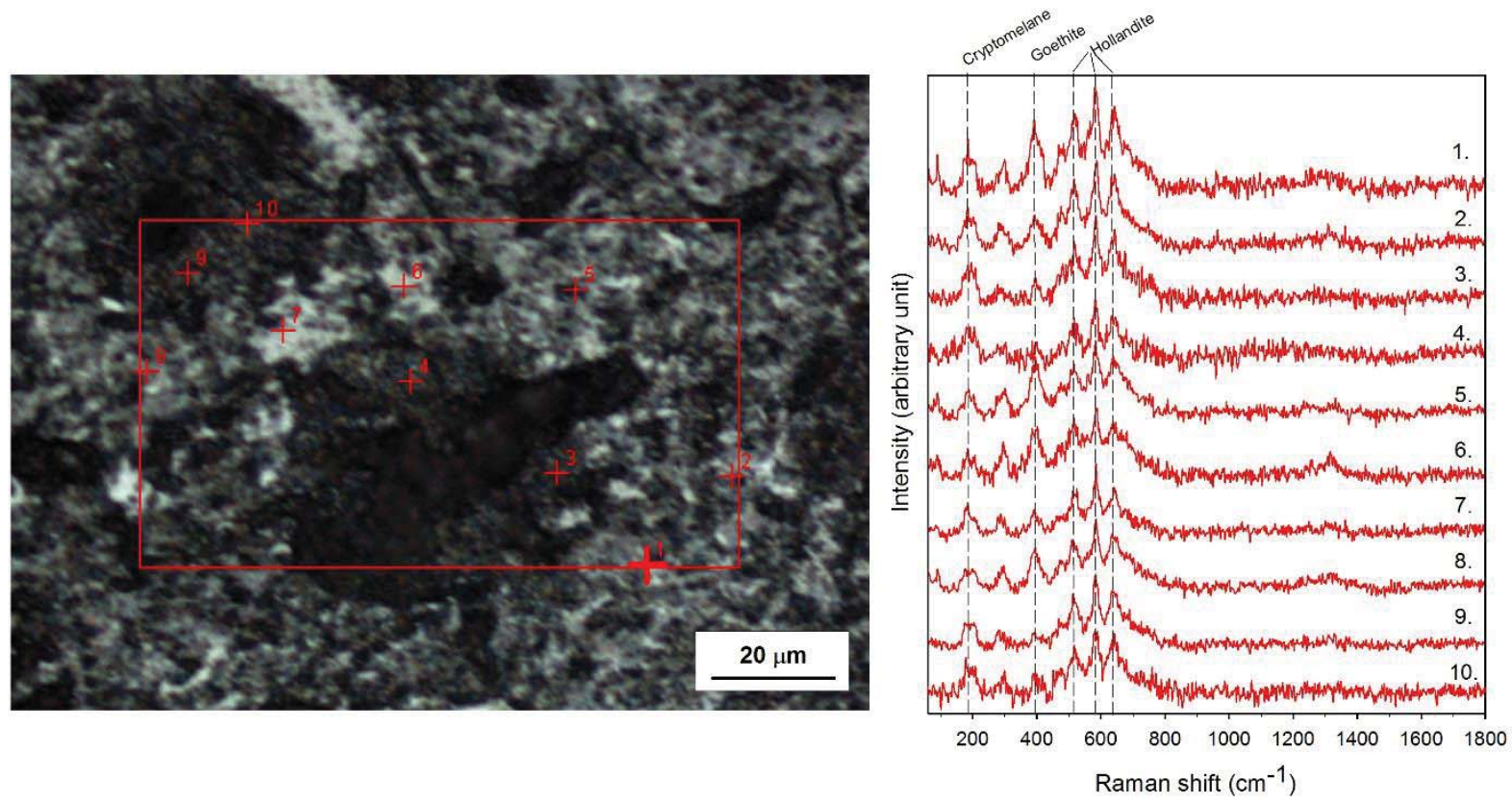

Figure 11.: Map indicated on the composite picture by yellow box marked by number 25 .

Comparing the mineral phases and distribution in the outer, inner and rim area of the measured spherical (bubble-like) structure, they are similar. 


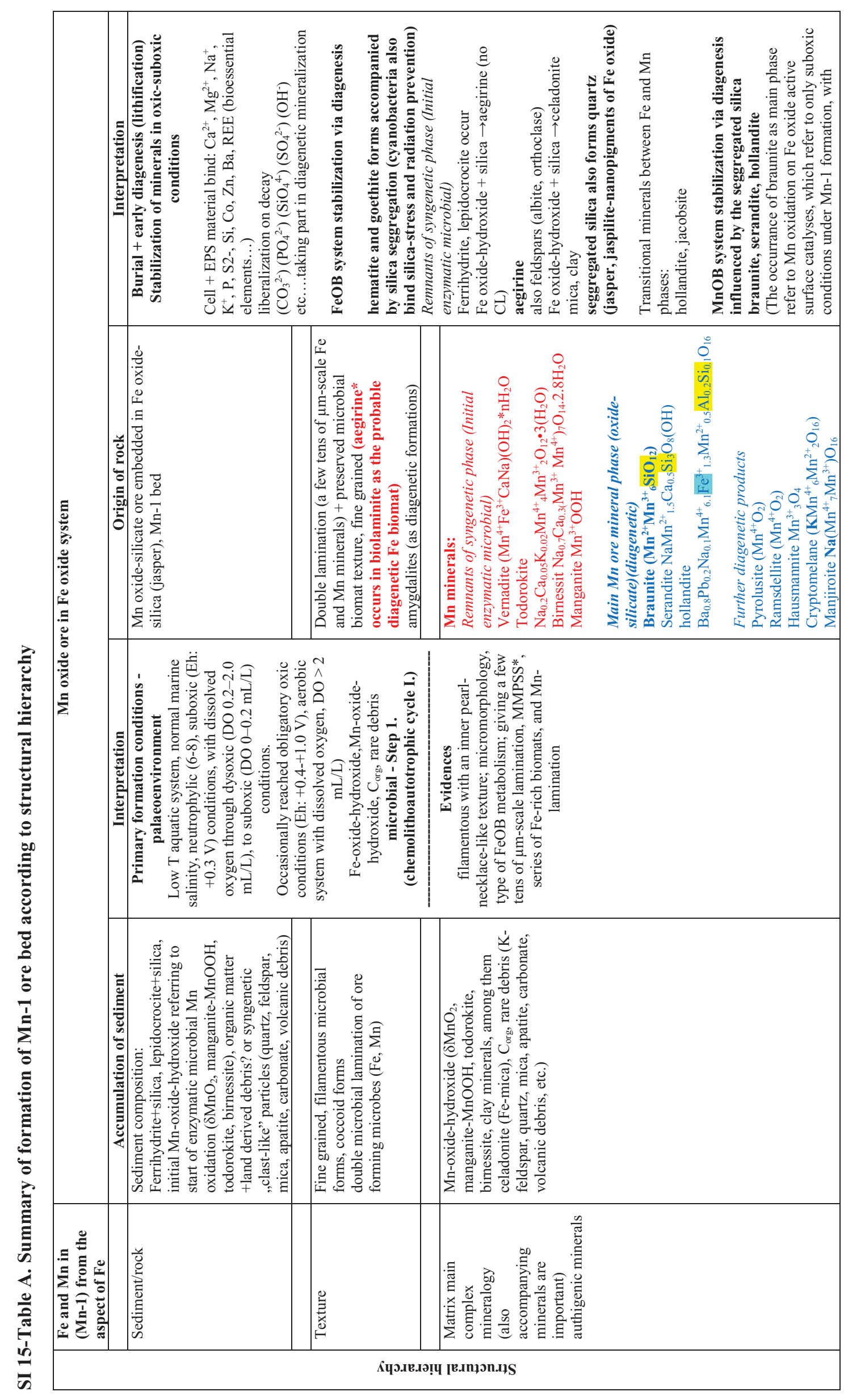

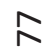




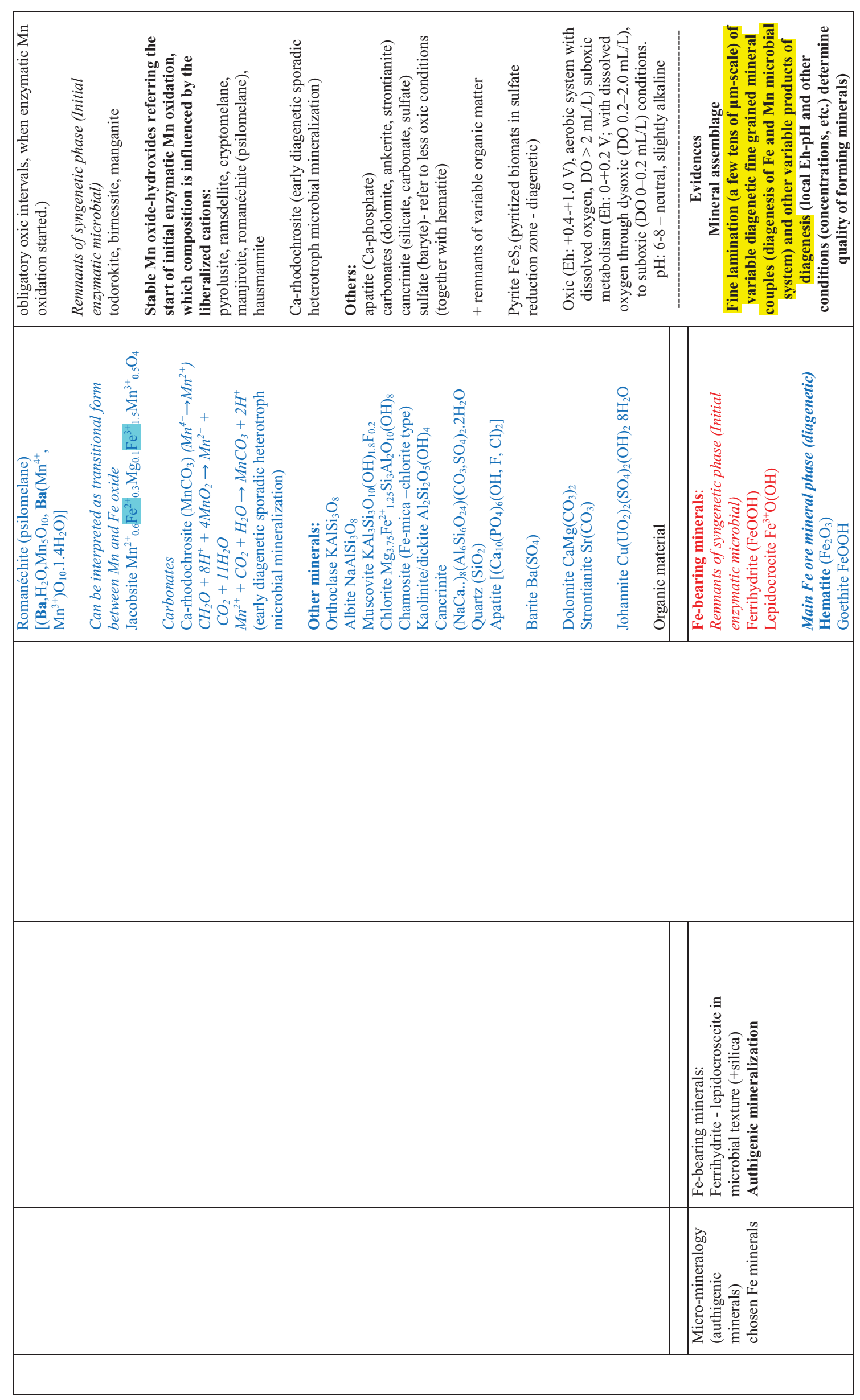

$\stackrel{\infty}{\wedge}$ 


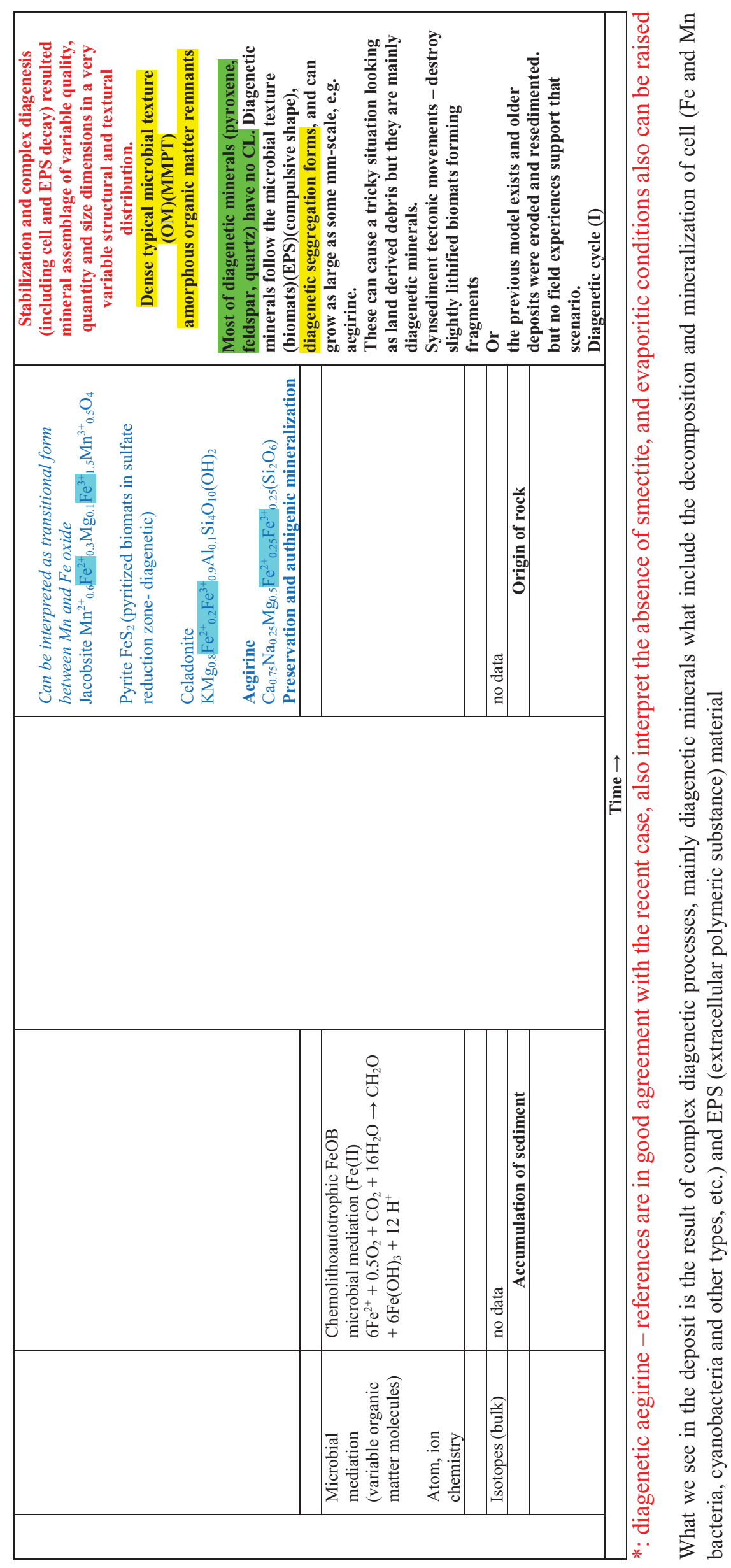




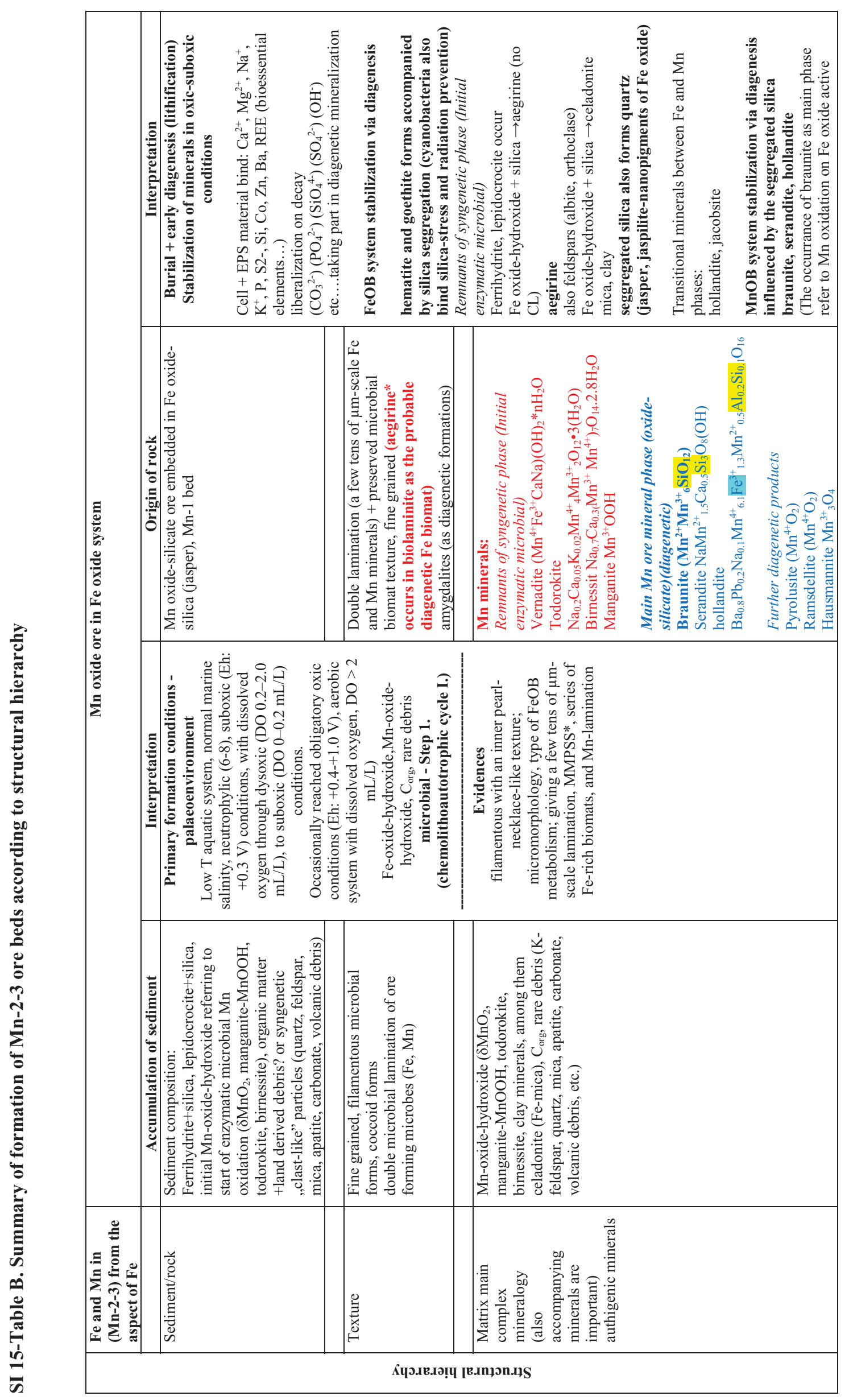

$\infty$ 


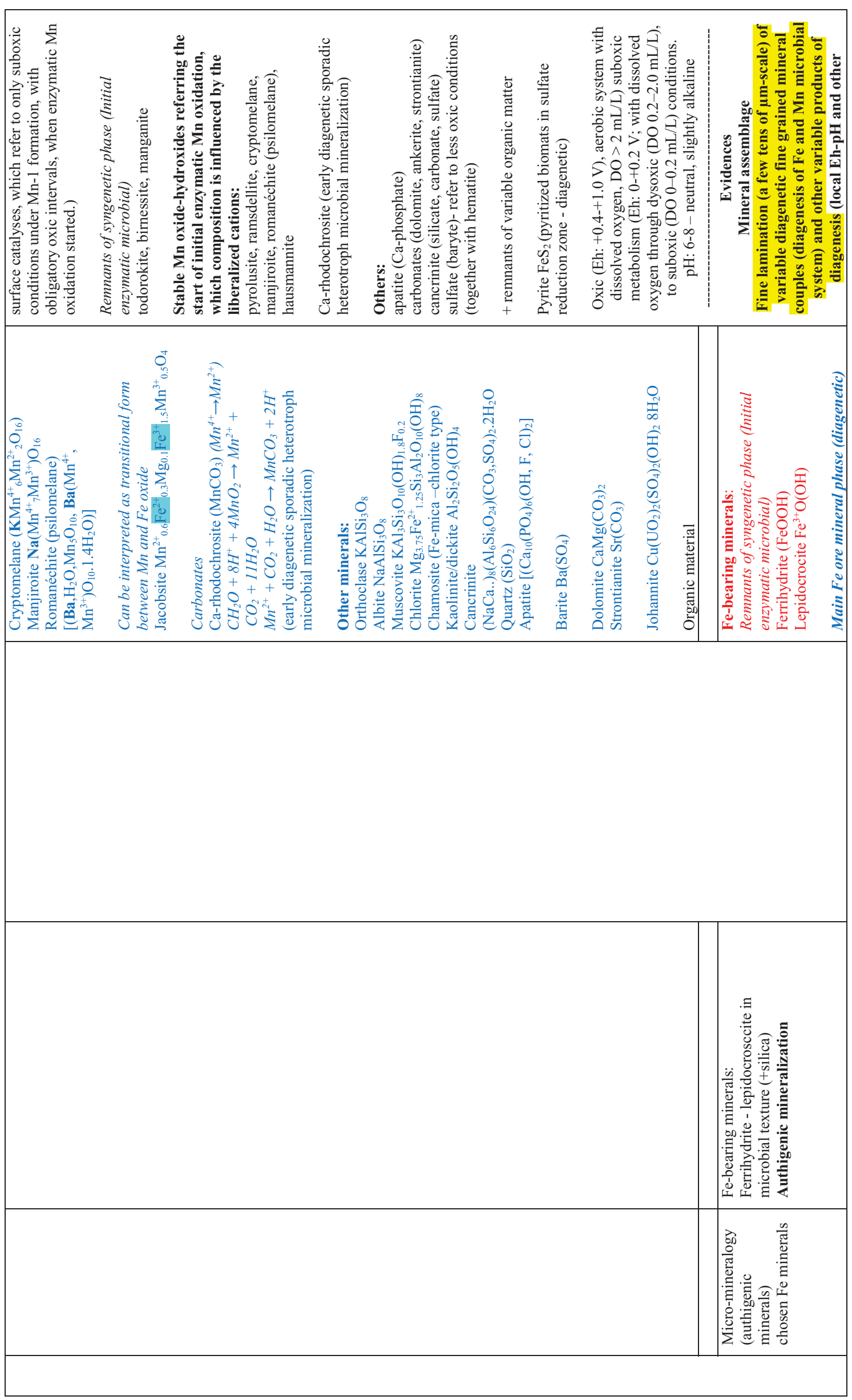

- 


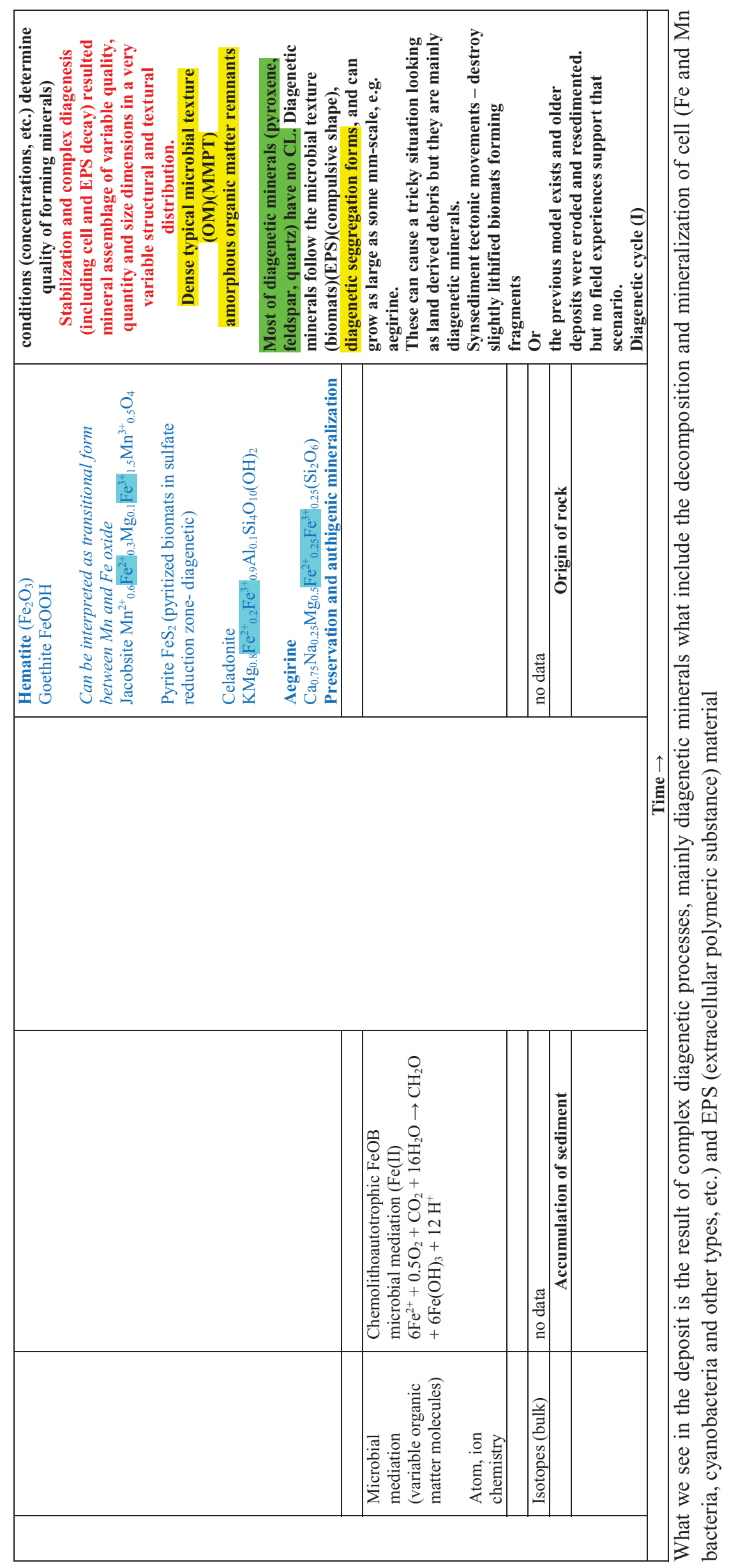

